\title{
بحوث العلاقات العامة والاعلان فى مصر الواقع واتجاهات المستقبل
}

\section{روئية تحليلية نقدية}

د/ ريم احمد عادل (*)

مقدمة : n - n

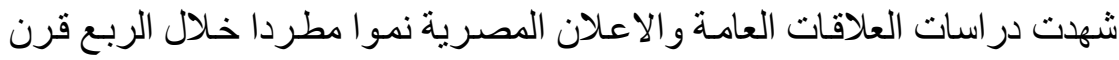
الاخير، فهناك تر اكما كميا فى البحوث العلمية على مستوى الرسائل العلمية (فى درجنى الاعنى

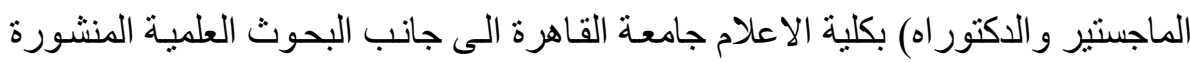

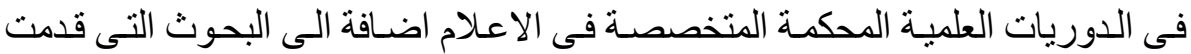

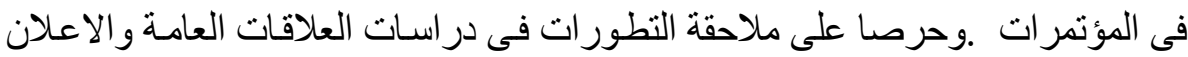

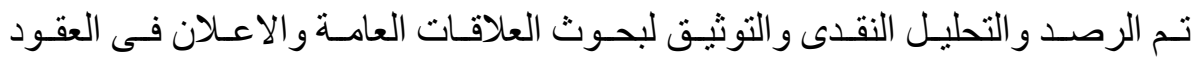
الماضية لتحديد المشكلات البحثية المثارة وطرق البحث واساليبه و ادوات جمع البيانات

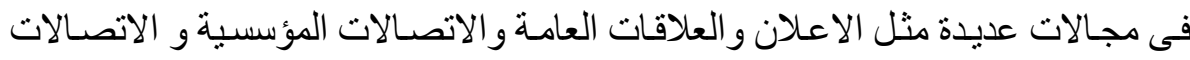

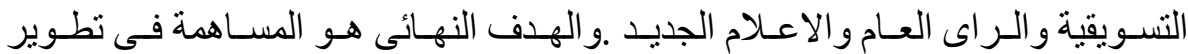

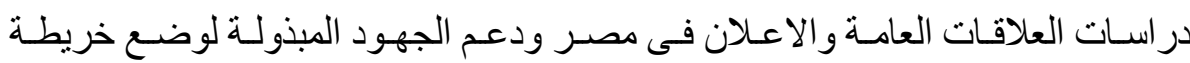

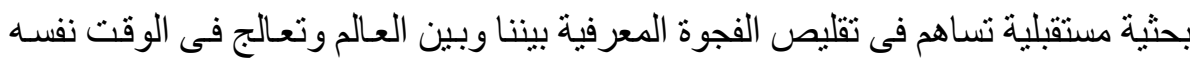

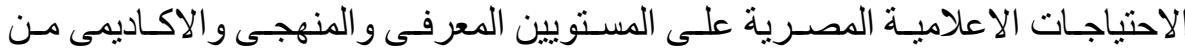

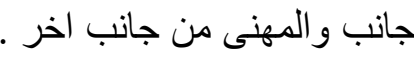
تنقسم هذه الاراسة الى ثلاث اجزاء هى : 1- الاطلار المنهجى للار اسـة (الموضوع - اهداف الدراسـة ـ المنهج المستخدم -عينـة الار اسة -فئات التحليل). 2- استعر اض للار اسات فى مجال العلاقات العامة و الاعلان 3- رؤية مستقبلية مقترحة لتطوبر در اسـات العلاقات العامـة و الاعلان المصرية بشكل

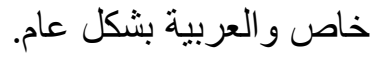




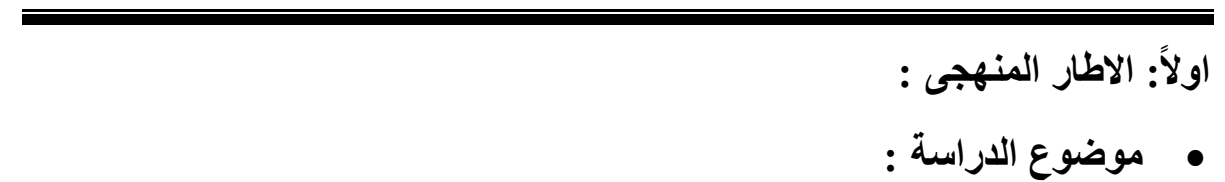

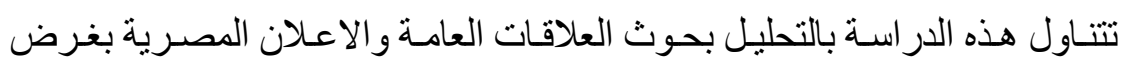

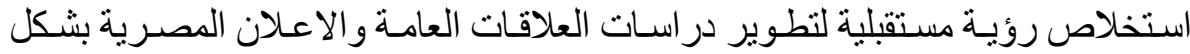

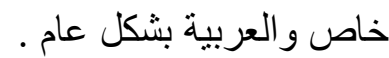
هدف الدراسة :

استخلاص رؤية مستقبلية لتطوير دراسات العلاقات العامة والاعلان المصرية .

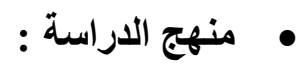

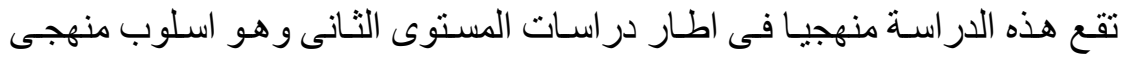

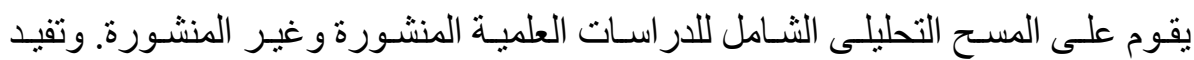

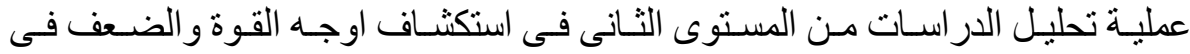

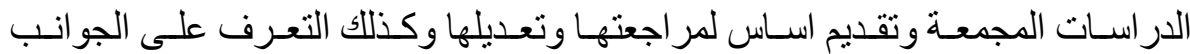

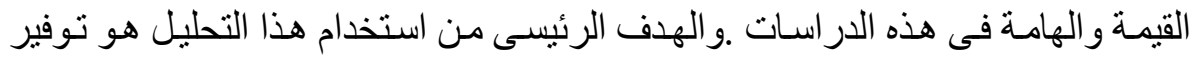

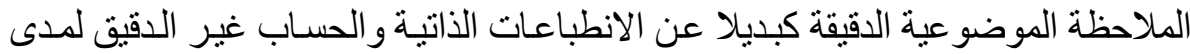

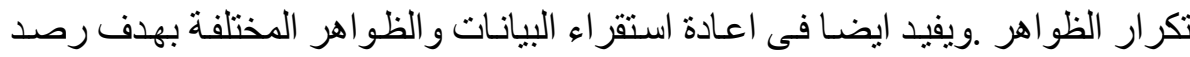

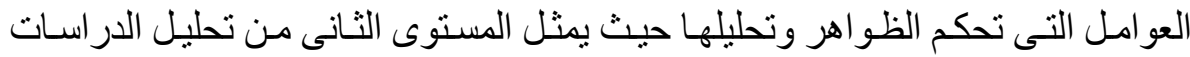

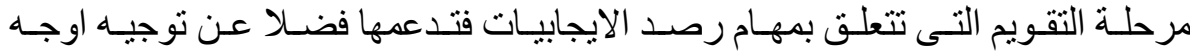

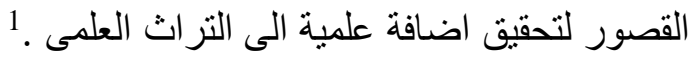
2: ويعتمد تطبيق اسلوب تحليل المستوى الثنانى على اتباع الخطو ات التالية

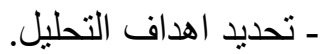
ـ تحديد فترة زمنية لاجر اء التحليل بما يدعم اهداف البحث. ـ حصر الدراسات ذات الصلة بموضوع البحث. ـ تصنيف البحوث وفقا للمتغير ات المختلفة . ـ كتابة التقرير ورصد الخلاصـات العامة لتحليل الدر اسات السابقة. ـ تقديم رؤى عامة لبحوث مستفبلية فى مجال الدراسة .

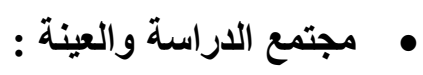
تم تطبيق هذه الدر اسـة على در اسـات العلاقات العامـة و الاعلان و التىى تم تقسيمها 


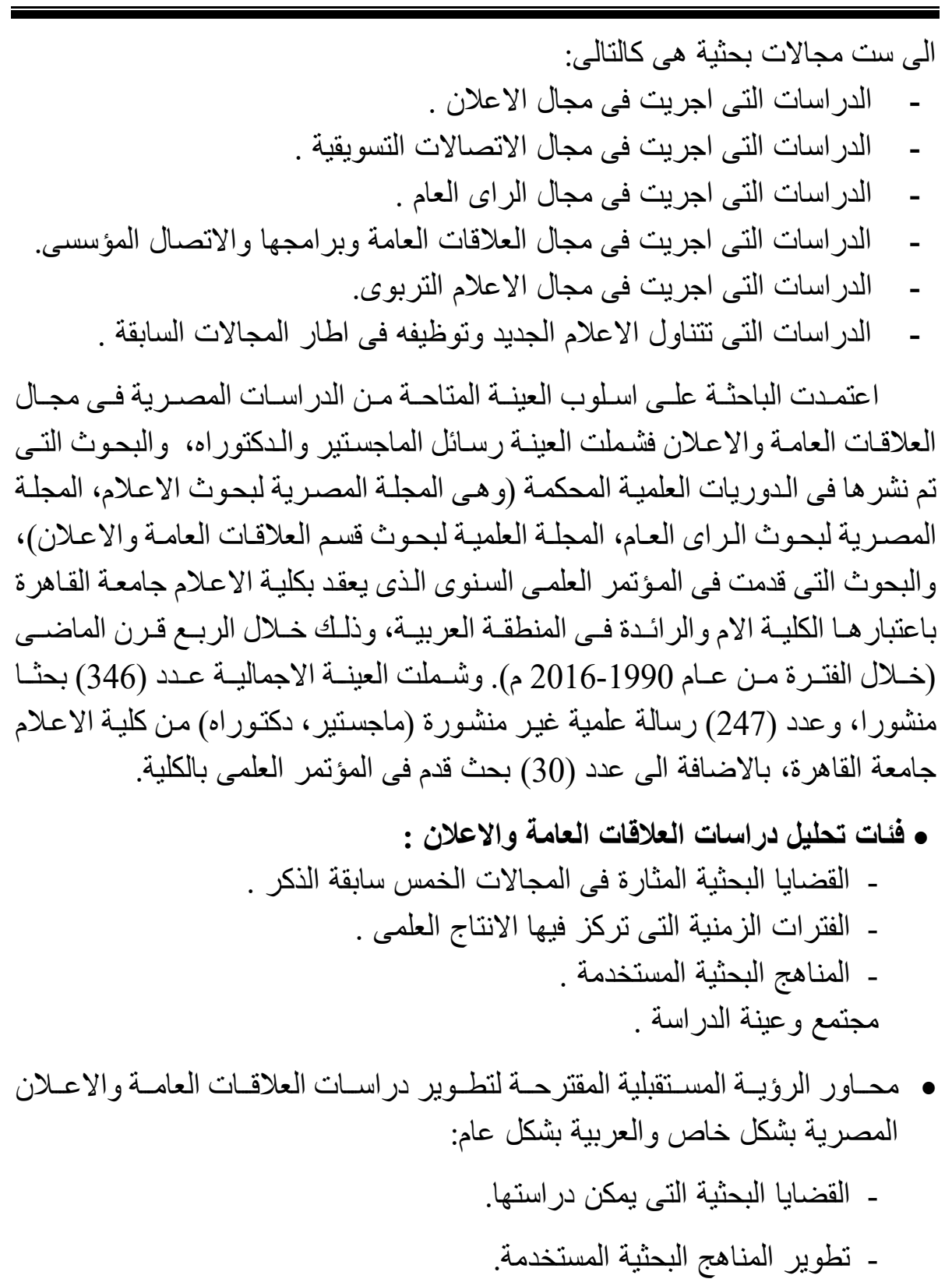


بحوث العلاقات العامة والاعلان فى مصر :الواقع واتجاهات المستقبل

ثانيا: عرضا تحليليا للار اسات فى كل مجال من مجالات العلاقات العامة والاعلان : الاراسات التى اجريت فى مجال الاعلان : تنو عت موضو عات الدراسات التى اجريت فى مجال الاعلان و الفترة الزمنيـة التى نركز فيها هذا الانتاج العلمى، وذلت على على النحو التالى:

(1) دراسات تتناول تأثير النشاط الاعلانى بشكل عام:3

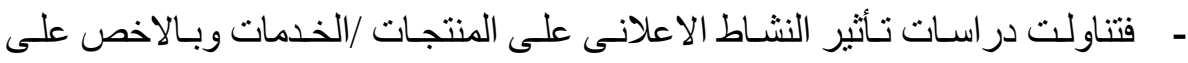
الصورة الذهنية لهاهومنها الدر اسة التى تنتاول: "دور الاعلان فى تكوين صورة ذهنية عن السلع والخدمات المعلن عنها (1999)". - و تناولت دراسات اخرى تأثثير النشاط الاعلانى على الجمهور بشكل عام،ومن هذه

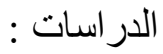
" أسـاليب الحيـاة التـى يعكســها الاعـلان التلبفزيــونى ومـــى ملاعمتهــا للجمهـور المستهذف (2001)" (1) و على السلوك الثرائى للجمهورمن جانب: "دور الاعلان الصحفى فى التأثير على السلوك الثرائى للجمهور المصرى (2007)". وعلى مستوى وعى الجمهور من جانب اخر : "الاعلانات الصحية فى التليفزيون اليمنى (2007)". "ادر الك الجمهـور المصـرى لمخـاطر اعلانــات المنتجـات الدوائيـة :دراسـة فـى تـانثير الثخص الثنالث(2008) (1208) ومن الاتجاهات البحثية الجديدة فى هذا الاطار :

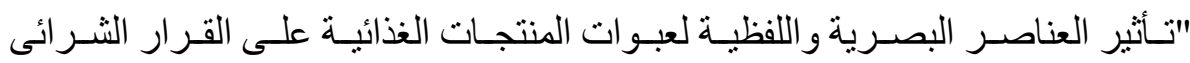

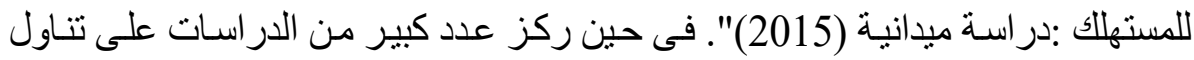
تأثير النشاط الاعلانى على فئة جماهيرية بعينها مثل: فئل

الاطفـال حيث تناولت بعض الدر اسـات تـأثير النشـاط الاعلانسى على الاطفـال بشكل عام،و على الحصيلة اللغوية للطفل، و على فهم وتذكر الطفل، و وعلى قيم الاطفال ومن التحن

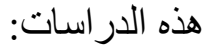


بحوث العلاقات العامة والاعلان فى مصر :الواقع واتجاهات المستقبل

" اثر اعلانات التليفزيون على الطفل المصرى :در اسـة ميدانية على عينة من اطفال

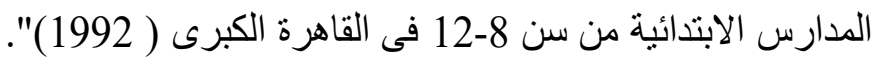
" تأثير الاعلانات التليفزيونية على الحصيلة اللغوية للطفل (1999)". "فهم وتـذكر الطفل الاردنسى للاعـلان التلبفزيـونى :دراسـة تجريبيـة على عينـة مـن

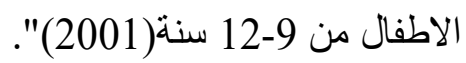
"الطفل العربـى والاعلانـات عبر التليفزيون :دراسـة على عينـة من الاطفال واوليـاء

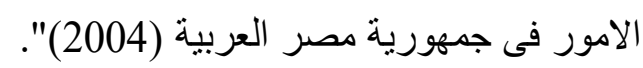
" فهم وتـذكر الاطفـال للاعـلان التليفزيونى :دراسـة تجريبيـة على عينـة مـن التلاميذ المصريين من 1-7 سنة (2006)". "تأثير الاعلان التليفزيونى على السلوك الثرائى للطفل المصرى (2007)". " القيم المنضــنة فى اعلانـات قنـوات الاطفـال العربيـة و علاقتهـا بالمنظومـة القيميـة

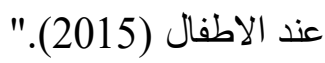
كمـا اهتمـت بعض الدراسـات بـالمر أة خاصـة تـأثير النشـاط الاعلانسى على السـلوك الثرائى او الاستهلاكى للمر أة ومنها: " تأثثير الاعلان التليفزيونى على السلوك الثرائى للمر أة المصرية (1995) ". "تأثير الاعلان التليفزيونى على السلوك الاستهلاكى للمر أة الاردنية در اسـة ميدانيـة . "(1997)

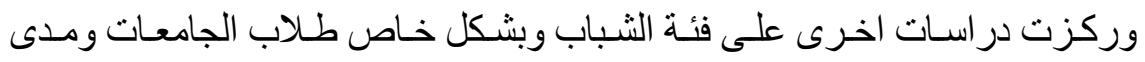

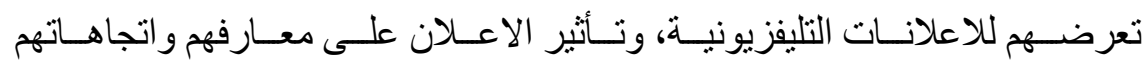
وسلوكياتهم،ومن هذه الدر اسات:

" نـاثير التعرض للاعلانـات التليفزيونيـة على اتجاهـات الثباب نحو الماديـة :در اسـة مسحية (2010) ".

"اتجاهـات طالبـات الجامعة نحو الاعلان التلبفزيونى :در اسـة مقارنـة على عينة من النـ

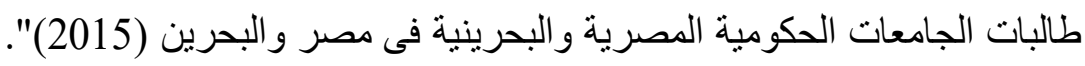
- تناول عدد محدود من الدر اسـات تأثثر احد مكونـات النشـاط الاعلانسى ومنها الرسـالة الاعلانية على الجمهور و اتجاهاته: 
بحوث العلاقات العامة والاعلان فى مصر :الواقع واتجاهات المستقبل

" تمثيل معلومـات الرسـائل الاعلانيـة المتناسقة لدى الجمهور :دراسـة تجريبية على الجى عينة من الثباب الجامعى (1999).

" تأثير التنافر المعرفى على اتجاه المستهلك وسلوكه :دراسـة تطبيقية على استخدام نظرية التنافر المعرفى فى الاعلان (2001)."

" اتجاهات الجمهور المصرى نحو الإعلانات التليفزيونية المثيرة للجدل واستجاباتهم نحو ها(2016)".

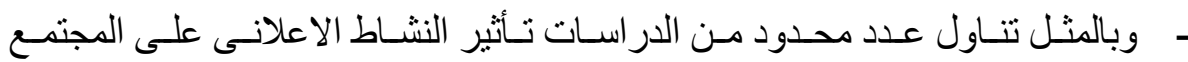

وبالاخص على الجو انب الاجتماعية والثقافية بالمجتمع ومنها:

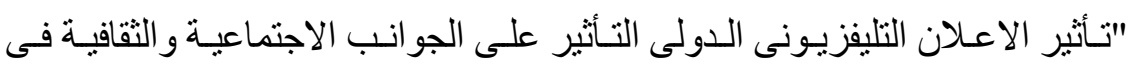

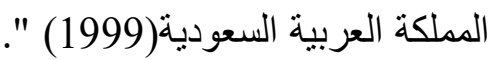
"الاعلان و ثقافة الاستهلاك فى عصر العولمة (2009)". " إسـهامات البـاحثين في تأصبل العلاقـة بين الإعلان و الهويـات الاجتماعيـة ـ رؤيـة نظرية(2016)".

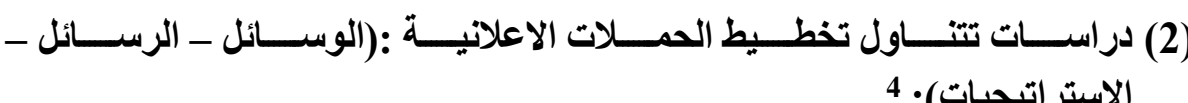

- بدأ هذا الاتجاه البحثى بتتـاول مرحلة محددة من مر احل تخطبط الحملات الاعلانية وهى مرحلة التقويم بدر اسة: " تقويم اساليب الاعلان التلبفزيونى فى مصر(1993).

- ثم اتجهت لتناول تخطبط الحملات الاعلانية من منظور اختبار الوسائل الاعلانية: " تخطيط اختيار الوسائل الاعلانية فى مصر :در اسة تحليلية ميدانية (1996)".

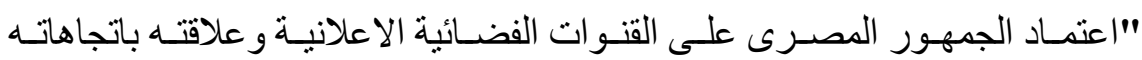
الثر ائية (2008)".

"مكانة اللافتات الاعلانبة بالمناطق الاثريـة فى مصر قطاع النحاسين بشـار ع المعز لدين الله الفاطمى (2011)". - ثم من منظور اختيار السياسات و الاستر اتيجيات الاعلانية محليا ودوليا: 
بحوث العلاقات العامة والاعلان فى مصر :الواقع واتجاهات المستقبل

"الاعلان عن السلع الاجنبية فى مصر :در اسـة تحليلية لاعلانـات السلع الاجنبية فى الإئ

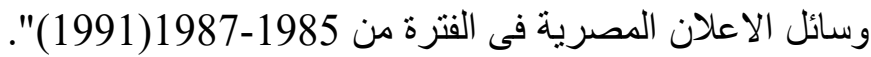

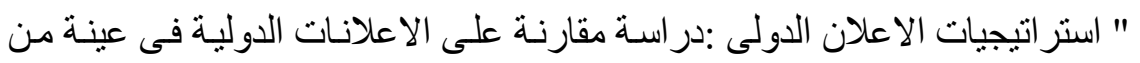
الدول العربية الاعلان الدولى (1998).

" السياسـات الاعلانيـة للمؤسسـات الصـحفية المصرية :در اسـة تحليلية ميدانيـة مقارنـة

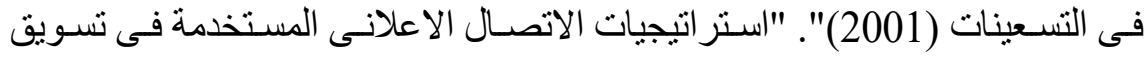
المجتمعات العمر انية الجديدة فى مصر :در اسة تحليلية ميدانية (2002)".

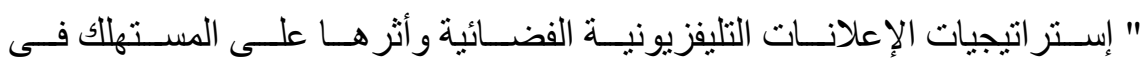
الجمهورية اليمنية:در اسة تحليلية ميدانية(2009)".

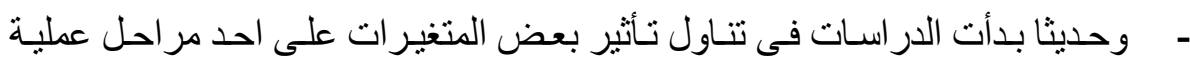
التخطيط للحملات الاعلانية ومنها اختيار الاستر اتيجيات الاعلانية:

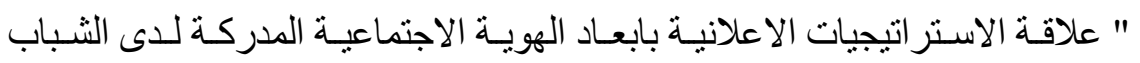
المصرى فى ظل العولمة: در اسة كيفية ( 2015).

5 : (3) دراسات تتناول اخلاقيات الممارسات الاعلاتية من الملاحظ محدوديـة الدر اسـات فى هذا الموضـوع و الفـارق الزمنسى الكبير بينها ومن

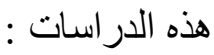

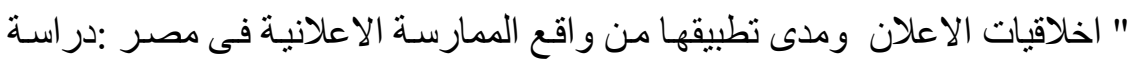

تحليلية لعينة من اعلانات التليفزيون المصرى (1997)."

"الممارسات الاعلانية و علافتها بمفهوم حمايـة المستهلك المصرى :در اسـة على عينـة من المستهلكين والثركات المعلنة فى مصر (2009)". "اخلاقيات الاعلان فى الفضائيات العربية المتخصصة (2010)"

"تجـاوزات نشـر الاعـلان الطبـى فـى الصـــافة المصـرية :دراسـة تحليليـة مقارنــة

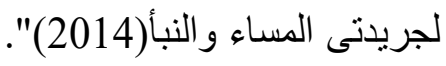

" تقيم الأداء الاتصـالى للمنظمـات المعنية بحمايـة المستهلك فـى التو عيـة من الإعلان

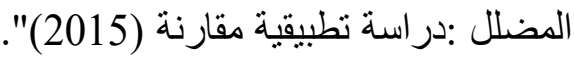


بحوث العلاقات العامة والاعلان فى مصر :الواقع واتجاهات المستقبل

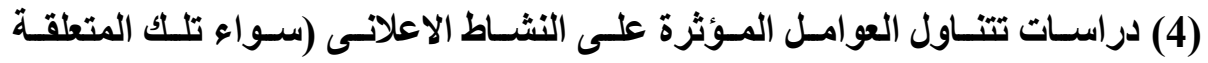
بالممارسين،الجمهور، المجتمع، النشاط الاعلانى ذاتهـ): 6

- فتناولت بعض الدراسـات الوكـالات الاعلانيـة و المعلنين باعتبـار هم مـن ممارسىى النشاط الاعلانى ومن هذه الدراسات:

"اتجاهات المعلنين نحو الاعلان فى مصر: در اسة ميدانية (1993)".

"دور وكـالات الاعـلان فـى النثــاط الاعلانسى فـى مصـر : دراسـة تحليليـة ميدانيـة

- وتتاولت دراسات اخرى العوامل المتعلقة بالجمهور من حيث :

دو افعه لاستخدام هذا النشاط:

"دوافع استخدام الجمهور المصرى للاعلان التليفزيونى واثباعاته (1995) ".

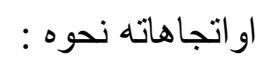

$$
\begin{aligned}
& \text { " الاتجاهات نحو الاعلان فى مصر :در اسة ميدانية ( 1999)". } \\
& \text { او نحو وسيلة اعلانبة معينة : }
\end{aligned}
$$

" اتجاهـات الجمهـور و المعلنين نحـو اعلانــات الطـرق در اســة ميدانيـة مقارنـة بـين

اتجاهاتهم نحو الاثكال التقليدية والحديثة (2002)".

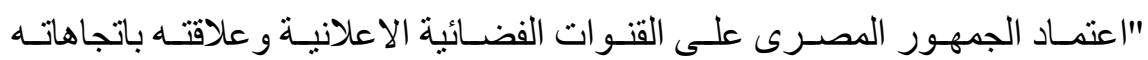

$$
\text { الثرائية (2008)". }
$$

"قارئيسة الاعـلان الصحفى فى مصر :در اسـة ميدانيـة على عينـة مـن قر اء الصـحف

$$
\text { ."(2012) }
$$

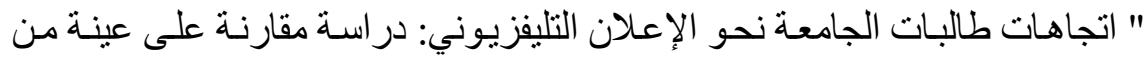

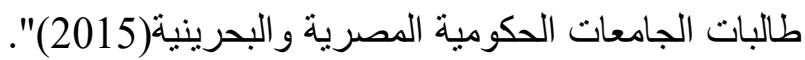

$$
\text { او نحو اسلوب معين فى الاعلان: }
$$

" اتجاهـات الجمهور المصـرى نحسو اسـتخدام الكوميديا فـى الاعلانـات التليفزيونيـة

$$
\text { ." (2009) }
$$

" اتجاهات الثباب نحو مصداقية المشاهير فى الاعلان ( 2009) ". 
بحوث العلاقات العامة والاعلان فى مصر :الواقع واتجاهات المستقبل

" اتجاهات الجمهور المصرى نحو اعلانـات العقار ات فى الصحف المصرية :در اسـة تحليلية ميدانية (2014)".

" الاعــلان السياسـى التلبفزيــونى فـى مصــر :در اســة حالــة الانتخابـات البرلمانيــة

".(2015)2012

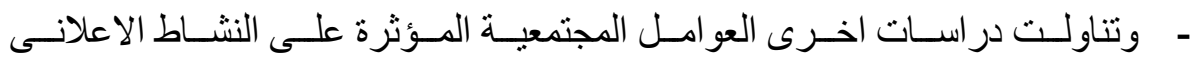
وبالاخص التغير ات السياسية والاقتصادية :

" التغيـرات السياسية و الاقتصـادية في اليمن ودور هـا فـى تطـور الاعـلان التجـارى

الصحفى (2004).

"الصسورة الذهنيـة للو لايـات المتحدة الامريكيـة وعلاقتهـا بتقبيم المسـتهلك لمنتجاتهـا

."(2007)

- واخير اركزت بعض الدر اسات على العو امل المتعلقة بالنشاط الاعلانى ذاته :

ومنها القيم التى تعكسها تصميم الرسائل الاعلانية:

"تـاثير القـيم التـى تعكسـهـا اعلانــات التلبفزيــون علـى الاتجاهــات نحـو الاعـلان

"تصــميم وتوظيـف الصـورة الافتراضـية فـى الاعـلان التليفزيـونى :در اسـة تحليـل

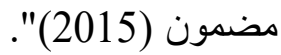

و توقيت عرض الاعلان: - مرن

" اتجاهات الجمهور المصرى نحو الاعلانـات التى يتم عرضـها اثنـاء عرض الدراما

و البرامج التليفزيونية: دراسة ميدانية على عينة من الجمهور المصرى الأنان (2012)."

"العلاقة بين استخدام العلامة التجارية داخل السياق الاعلامى وتذكرها (2016)".

- و هناك دراسات تعرضت لمجمل العو امل المؤثرة على فاعلية النشاط الاعلان:

"العو امل المؤثرة على فعالية الاعلان التليفزيونى فى مصر :در اسـة تحليلية ميدانية

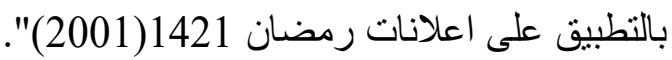

7: الداسات التى تثناول اقتصاديات النشاط الاعلانى (5) لوحظ محدودية الدراسات التى تتناول هذا الموضوع و التى اقتصرت على تحليل الانفاق 
بحوث العلاقات العامة والاعلان فى مصر :الواقع واتجاهات المستقبل

الاعلانى التجارى وتوزيعه على الوسائل :

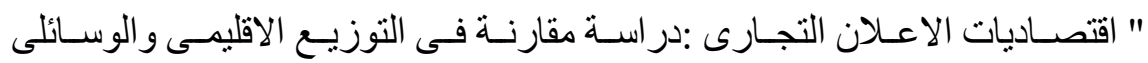
و السلع (2000)".

\section{التعليق على العرض السابق من حيث :}

•• الفترات الزمنية التى تركز فيها الانتاج العلمى فى مجال الاعلان:

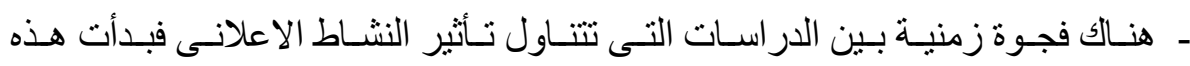

الدر اسات فى 1999و استمرت على فتر ات متقطعة حتى 2016.

- وبالمثنل تناولت بعض الدراسـات تـاثير النشـاط الاعلانـى على فئسة جماهيريـة معينـة

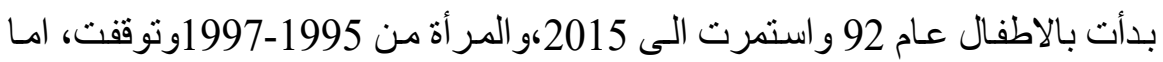

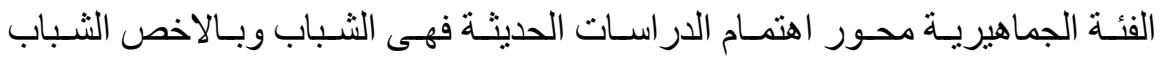

$$
\text { الجامعى وبدأت هذه الدر اسات 2005-2015. }
$$

- - بدأت الدر اسات التى تتنـاول تخطبط الحملات الاعلانية فى عام 1993 بتناول مرحلة

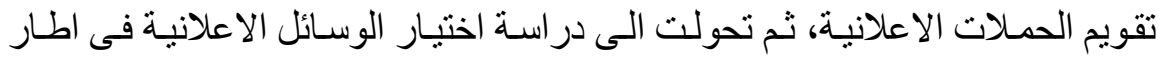

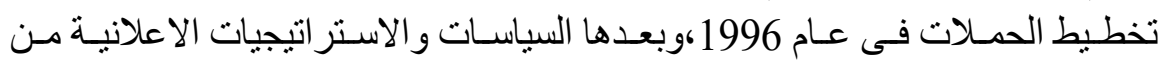

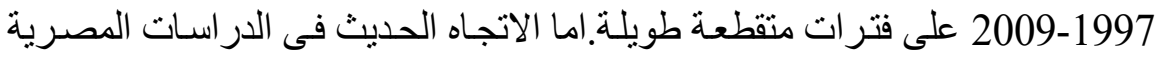

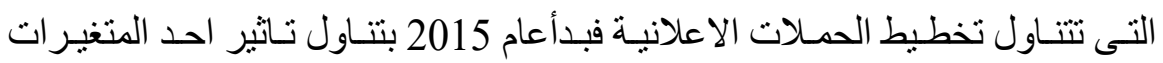
الاتصالية / التنظيمية/ المجتمعية على احد مر احل عملية التخطيط للحملات الاعلانية.

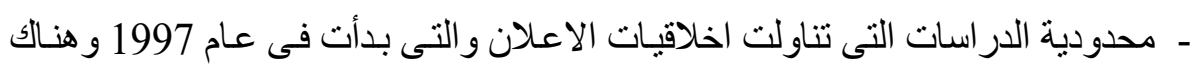

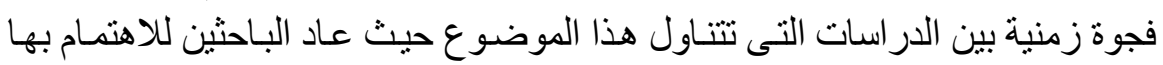
من عام 2009 حتى 2015.

ـ وتـوازى مـع الموضــو عات السـابقة تنـاول الدر اســات للعو امـل المـؤثرة علـى النشـاط

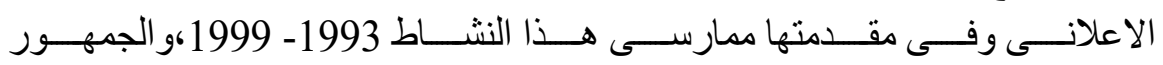

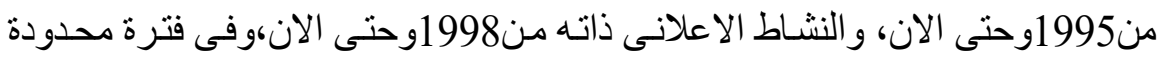

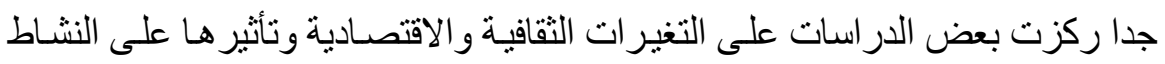

$$
\text { الاعلانى الن ركزت } 2004 .
$$

ـ انحصرت الدراسات التى تتناول اقتصاديات الاعلان فى عام 2000 فقط. 
بحوث العلاقات العامة والاعلان فى مصر :الواقع واتجاهات المستقبل

: نوع ومنهج الاراسات :

ان معظم الدر اسـات فى هذا المجـال در اسـات ميدانيـة وتليهـا الدر اسـات التحليليـة او الاثتين معـا و غالبيتهـا كانت در اسـات مقارنـة، وجـاء فـى المرتبـة الثالثـة وبفـارق كبيـر الدراسات التجريبية.

\section{• م ادوات جمع البيانات ومجتمع الاراسة والعينة :}

اعتمدت الدراسات فى هذا المجال على استمارة الاستقصـاء الموجهة للجمهور العام

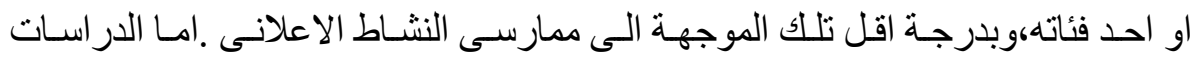

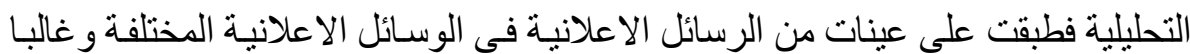

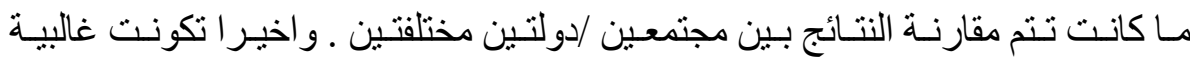

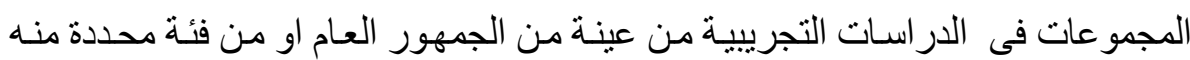

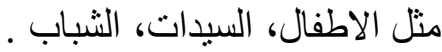

الاراسات التى اجريت فى مجال الاتصالات التسويقية:

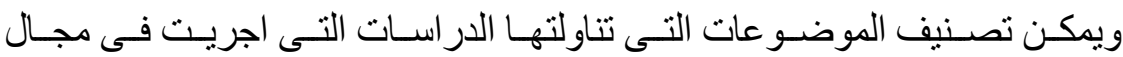

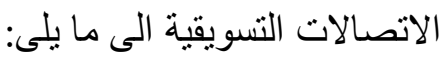

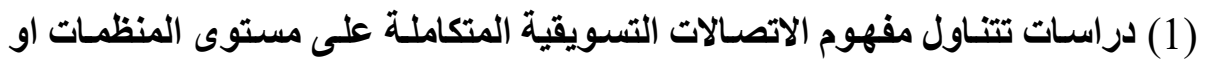

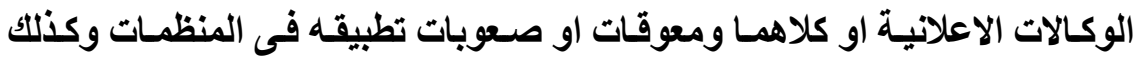

المسئول عن تطبيقه ومنها:8

$$
\text { " الاتصالات التسويقية الموحدة ( 2000)". }
$$

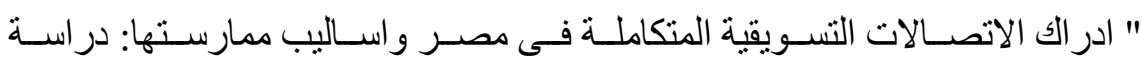

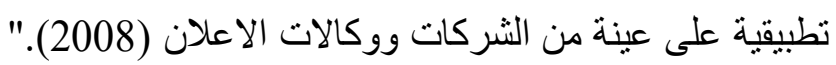

(2) دراسات تتناول تطبيق الاتصالات التسويقية المتكاملة فى نمط معين من المنظمسات

" الاتصــال التسـوبقى المتكامـل فـى الثــركات متعـددة الجنسـية العاملـة فـى مصـر

:در اسة تطبيقية( 2009 ) )".

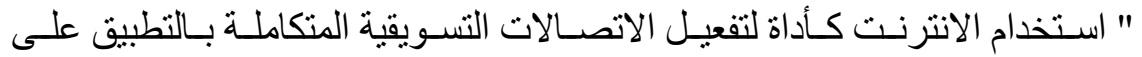

$$
\text { الثركات السياحية فى مصر (2010)". }
$$


بحوث العلاقات العامة والاعلان فى مصر :الواقع واتجاهات المستقبل

"الاتصـالات التسـويقية المتكاملـة المستخدمة فـى تسـويق الخـمات التعليميـة :در اســة على عينة من الجامعات المصرية الخاصة (2011)".

10: (3) كيفية استخدام احد انشطة الاتصالات التسويقية المختلفة والتنسيق بينها

ومنها التسويق المباثر :

"العو امل المؤثرة على فعالية أساليب التسويق المباثتر فى مصر :دراسـة مقارنـة على

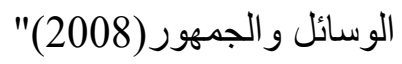

اساليب تنشيط المبيعات: - n

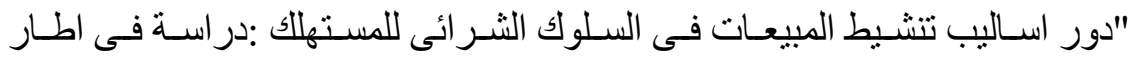

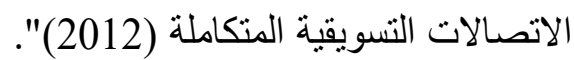

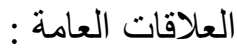

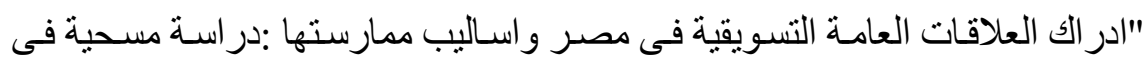
اطار مدخل الاتصالات التسويقية المتكاملة (2015)".

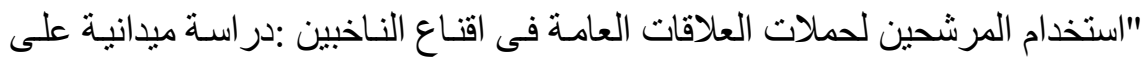
مرشحى الانتخابات البلدية بمنطقة الرياض الميلات (2016)".

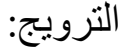

"فعالية الاسـاليب الترويجيـة فى تنميـة السياحة الداخلية فى المملكة العربيـة السعودية ."(2007)

"دور الاسـاليب الترويجيـة في نتكيل معرفة واتجاهـات وسلوك الجمهور المصـرى نحو صناعة التأمين (2014)".

وفى اتجاه جديد فى هذا المجال تتاولت احد الدراسـات اسلوب تسويقى جديد هو التسويق

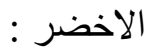

"العلاقة بين استخدام الثركات للتسويق الاخضر وتحقيق المزايا التنافسية (2016)"

(4) تأثير الاتصالات التسويقية المتكاملة:11 بشكل خاص على العلامة التجارية ومن هذه الدر اسات: " تأثير الانشطة الاتصالية المتكاملة على العلاقة بين الجمهور المصرى والعلامـات 
بحوث العلاقات العامة والاعلان فى مصر :الواقع واتجاهات المستقبل

التجارية(2009)".

وعلى الانساق الثقافية للجمهور ومن هذه الدراسات:

"محددات تأثثير الاتصـالات التسـويقية للهويـة التجاريـة الدوليـة على الانسـاق الثقافيـة

$$
\text { للجمهور المصرى (2012)". }
$$

" تأثثير استخدامات الاتصالات التسويقية على العلاقة بين البنوك وجمهور ها:در اسـة

$$
\text { حالة (2013)". }
$$

(5)تناولت دراسـات محدودة العوامـل المـؤثرة علـى ممارســات الاتصـالات التسـويقية المتكاملة او احد ادواتها ومنها:12

"تـأثنير الازمـة الماليـة العالميـة على الانشــة الترويجيـة للثـركات فـى مصـر عـام

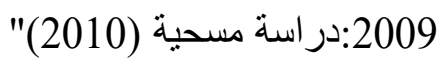

" تـأثير التكامل بين وظـائف العلاقـات العامـة والتسـويق علـي الاتصـالات التسـويقية للمنظمة(2013)".

" اتجاهـات المســتهلكين نحـو عـروض تــرويج المبيعـات داخـل متــاجر التجزئــة

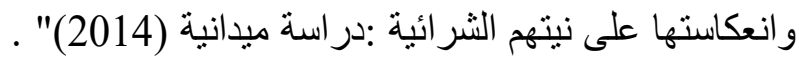

$$
\text { (6) دراسات التسويث الاجتماعى والسياسى: }
$$

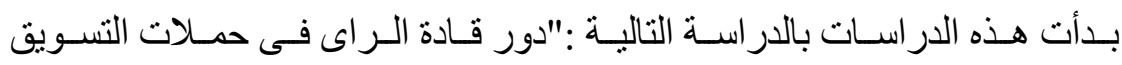

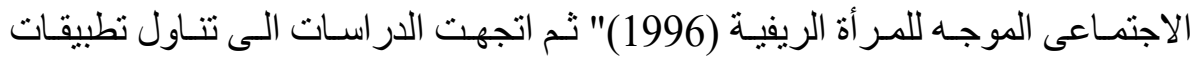

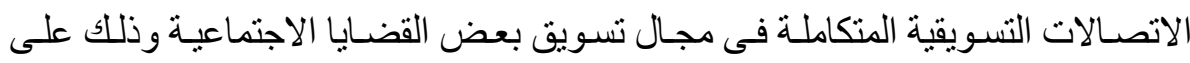

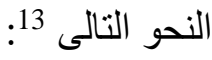

" تطبيقـات الاتصـالات التسـويقية و انعكاسـاتها على فعاليـة حملـة التو عيـة المروريـة

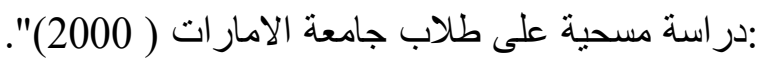

"تخطــبط حمـلات التسـويق الاجتمـاعى :بــالتطبيق علـى حمـلات الصـحة العامــة ."(2001)

"تأثير بر امج التسويق الاجتماعى لقضية التلوث الصناعى فى مصر (2002)".

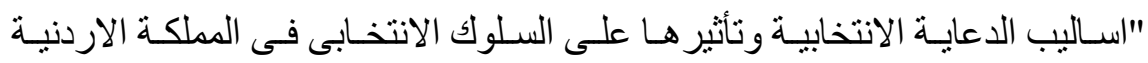
الهاشمية :در اسة حالة لانتخابات تشرين الثانى (2002)". 
بحوث العلاقات العامة والاعلان فى مصر :الواقع واتجاهات المستقبل

" الاتصـال التسويقى المتكامل فى نشـاط السياحة الو افدة الى مصر :در اسـة نطبيقيـة على رعاية المناسبات و الاحداث السياحية ( 2005)".

" تقييم دور حملات التسويق الإجتماعية فى دعم المشاركة المجتمعية (2008)".

"اتجاهـات الثشباب المصـرى نحـو الحمـلات الاعلاميـة الخاصـة بتعزيـز القيم الدينيـة والاخلاقية (2009)".

"دور حمـلات التسـويق الاجتمـاعى فـى دعـم مفهـوم المواطنــة ومناهضــة الاسـتبعاد الاجتماعى (2010)".

"التسـويق السياسـى للاحز اب و الجماعـات السياسية المصرية :در اسـة تطبيقيـة على الانتخابات التشريعية نوفمبر 2010 (2011)".

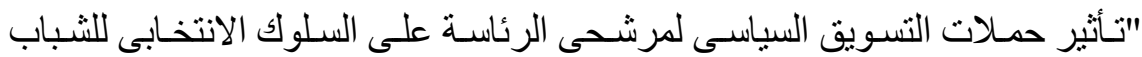
المصرى فى انتخابات الرئاسة 2012 ( 2013)".

"العو امل المؤثرة على فعالية حملات التسويق الاجتمـاعى فى مصر :در اسـة تطبيقية

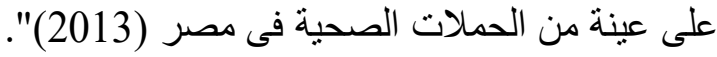

"دور حمـلات التسـويق الاجتمـاعى فـى دعم التغييـر فـى المملكـة العربيـة السـعودية :در اسة تطبيقية على حملات الحوار الوطنى السعودى (2014)".

"دور الاتصـالات التسـويقية فـى دعم اسـاليب الترويج السـياحى لمصـر فـى الــاخل

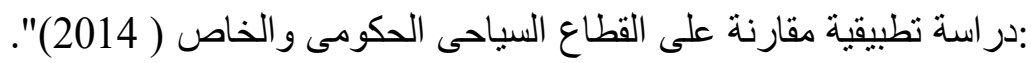

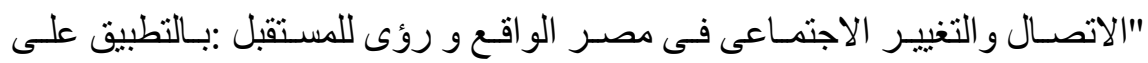

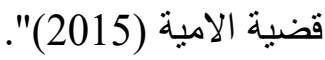

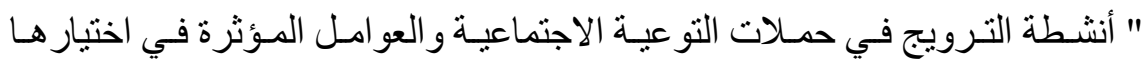
در اسـة ميدانيـة على عينـة مـن المؤسسـات الحكوميـة و المجتمعيـة في المملكة العربيـة العية

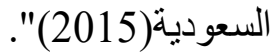
"الاتجاهات الحديثة فى دراسات التسويق الاجتماعى (2015)". " الاتجاهات الأساسية في نظرية التسويق الاجتماعي دراسة استطلاعية(2016)". 
بحوث العلاقات العامة والاعلان فى مصر :الواقع واتجاهات المستقبل

التعليق على العرض السابق من حيث :

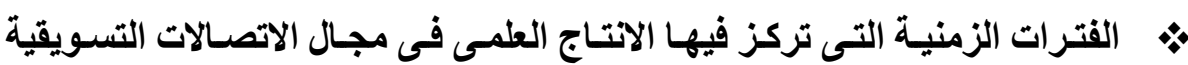

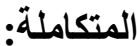

لوحظ تر اجع الدر اسات العربية من حيث الكم، فقد بدأت الدراسـات العربية البحث

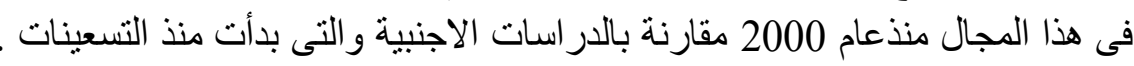

ـ بـدأت الدر اسـات فـى هـذا المجـال بتتـاول مـدى ادر الك مفهـوم الاتصــالات التسـويقية

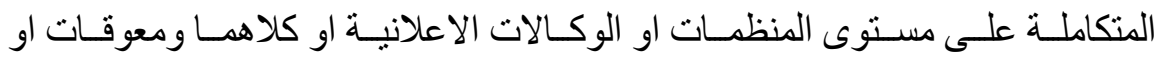

صعوبات تطبيقه فى المنظمات وكذلك المسئول عن تطبيقه منذعام 2000-2008.

ـ ـ وبعده بدأت الدراسات فى تناول كيفية ومعدل استخدام الاتصـالات التسويقية المتكاملة

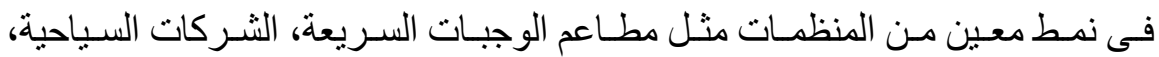
الجامعات المصرية،البنوك من 2007-ومستمر حتى الان.

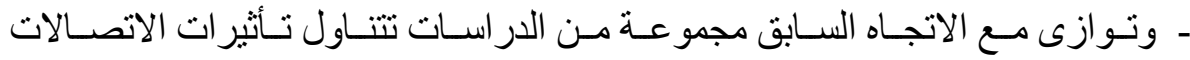

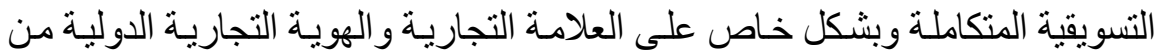

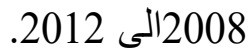

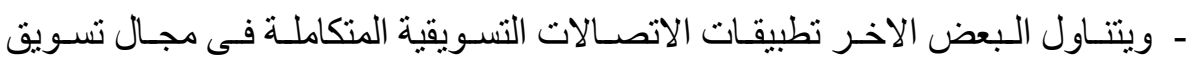

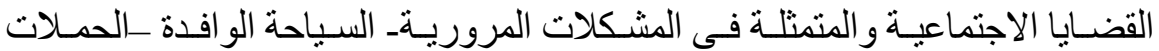
الصحية -حملات الحوار الوطنى منذعام 2000-ومستمر حتى الان. ـ ـ الاتجاه الجديد من الدر اسات فى هذا المجال يختص بتناول و اقع التخطيط للاتصـالات

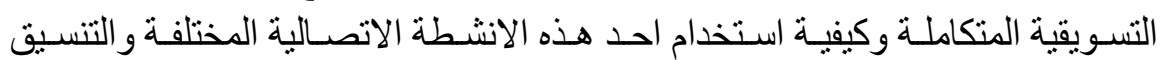

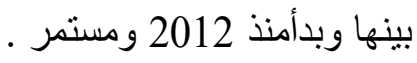

$$
\text { : : نوع ومنهج الدراسة }
$$

يغلب على الدر اسـات المصـرية بشـكل خـاص و العربيـة بشـكل عـام فـى مجــال

الاتصالات التسويقية التحليل الكمى للبيانات فكانت غالبية الدراسـات در اسـات ميدانية او

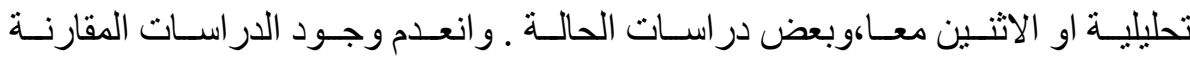
و والتجريبية . 
بحوث العلاقات العامة والاعلان فى مصر :الواقع واتجاهات المستقبل

• ادوات جمع البيانات ومجتمع وعينة الاراسة :

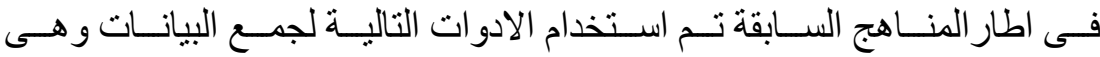

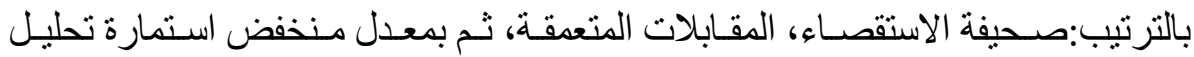

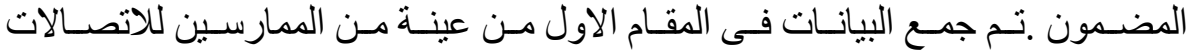

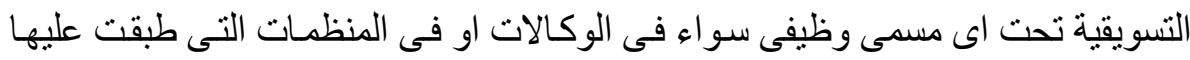
الدراسة ، او من عينة من الجمهور المستهدف .

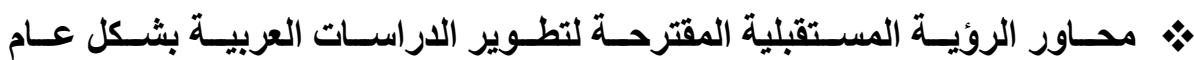
والمصرية بشكل خاص فى مجال الاعلان و الاتصالات التسويقية:

ـ ـ تتجه الدر اسـات الاجنبية الان للتحليل الكيفى على العكس من الدراسـات العربية التىى غلب

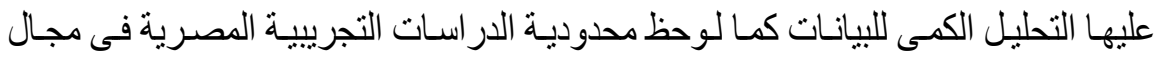
الاعلان وانعدمها فى مجال الاتصالات التسويقية وندرتها فى الدر اسات الاجنبية .

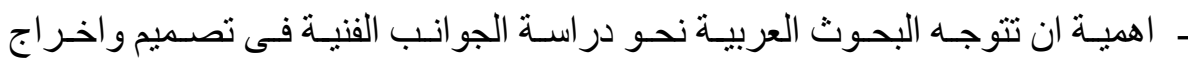

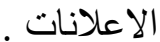

ـــ ـ الحاجة لمزيد من الدر اسات المعنية بتشريعات الاعلان واخلاقياته حيث انها محدودة جدا . ـ ـ الاهتمـام بالدر اسـات التى تتتـاول مرحلـة تقويم الحمـلات الاعلانيـة باعتبار هـا مـن اهم المر احل التى تساهم فى تطوير المجال.

ـ ـ والتوسع فـى الدر اسـات التـى تنـاول تـاثير مجموعـة مـن العو امل التنظيمية و المجتمعية

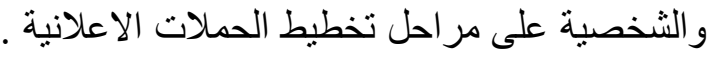

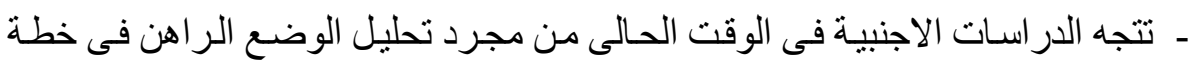

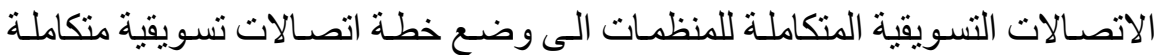

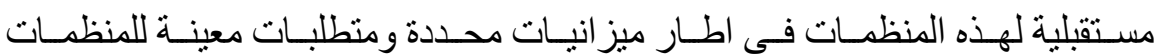
الانتاجية او الخدمية او المنظمات غير الهادفة لتحقيق الربح.

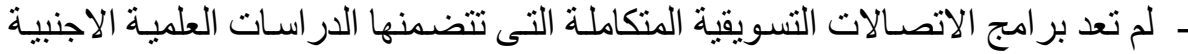

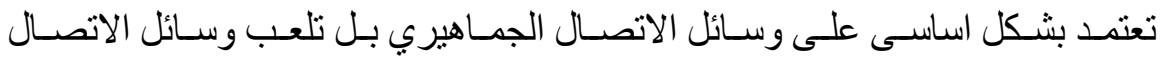

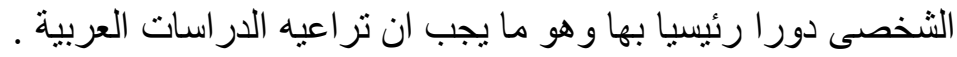

ـ ـــن الموضـو عات الحديثـة التـى يجـب الاهتمـام بهـا اسـتخدام الاتصــالات التسـويقية المتكاملة فى الترويج لوسائل الاعلام. 
بحوث العلاقات العامة والاعلان فى مصر :الواقع واتجاهات المستقبل

- و وايضـا دور الاتصـالات التسويقية المتكاملـة فى مجـال التسـويق السياسـى واستخدامها

مـن قبل الاحز اب السياسبة والمرشـين السياسبن خاصـة فى ظل التغير ات السياسية

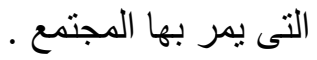

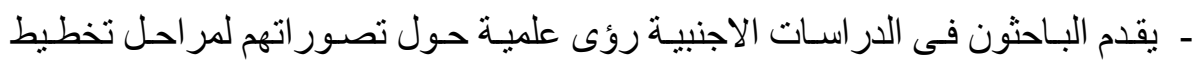

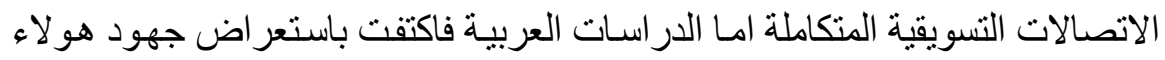
الباحثين كخلفية نظرية لموضو عاتهم دون الاجتهاد فى تقديم رؤى مختلفة.

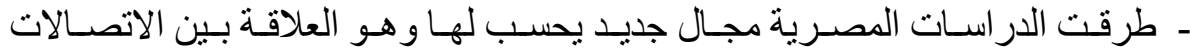

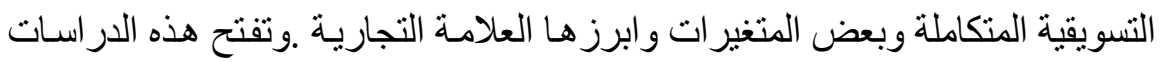

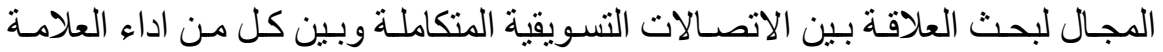

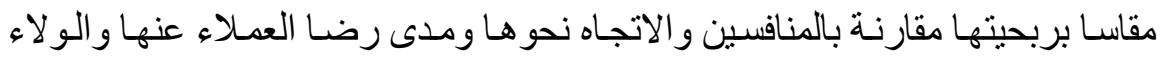

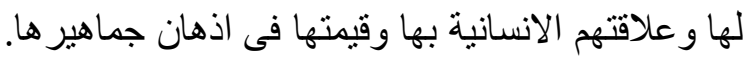

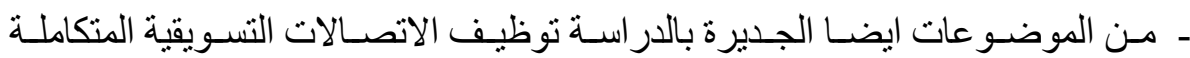

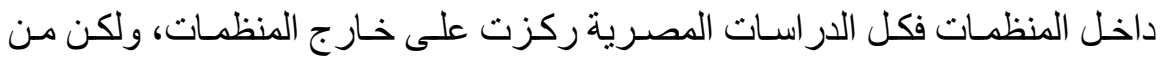

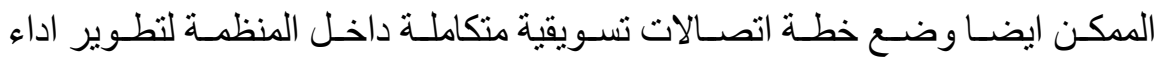
العاملين وزيادة الربحية .

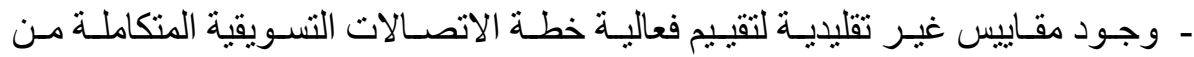

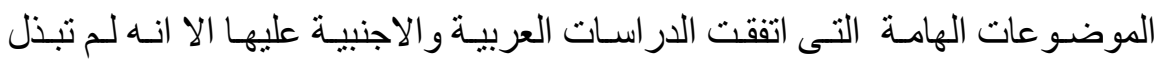
محاو لات عربية لوضع مؤشرات تفيد فى هذا التقييم . ايضا من الموضوعات التى نوصى باهمية اجراء بحوث مستقبلية بها فى هذا المجال : - معوقات التوجه نحو الاتصالات التسويقية المتكاملة .

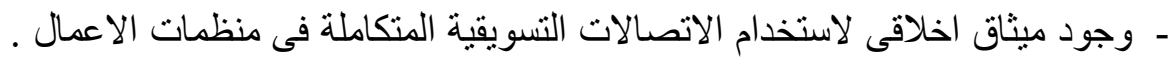
ـ - تحليل المخاطر التسويقية لظاهرة نقص الو لاء لاء للعلامة التجارية. - ـ رصد وتحليل نأثير الإعلانات الترفيهية على هوية العلامة التجارية المعلن عنها.

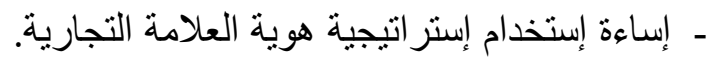

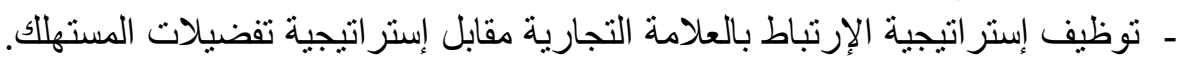
- ـ إستخدام إستر اتيجيات خلق المعوقات التسويقية أمام العلامات التجارية للمنافسين.

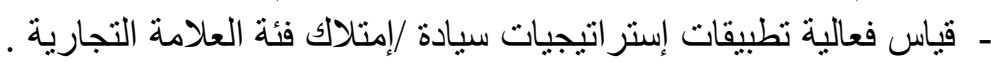

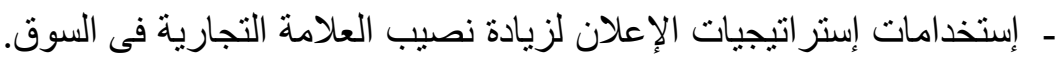
ـ ـ تحديات إرتباط الشخصيات المشهورة بعلامات تجارية بعينها. 
بحوث العلاقات العامة والاعلان فى مصر :الواقع واتجاهات المستقبل

ـ - إستخدامات إعلانات إمتداد العلامة التجارية.

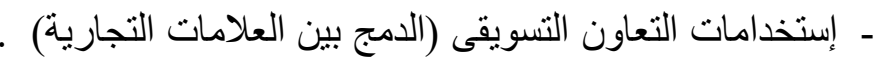

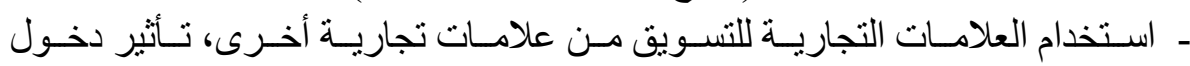

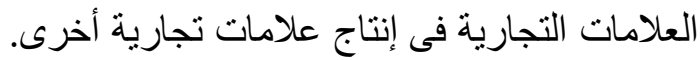

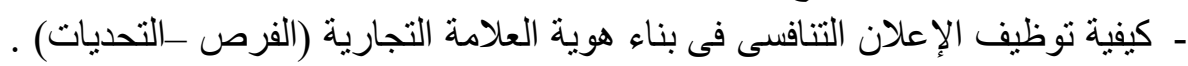

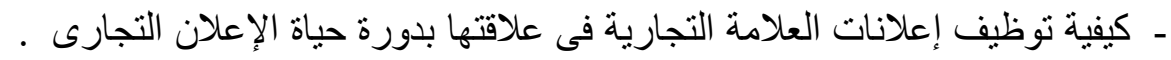

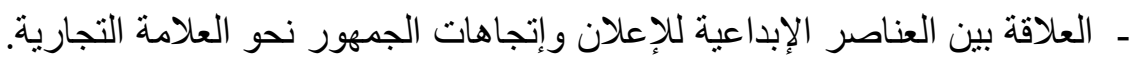

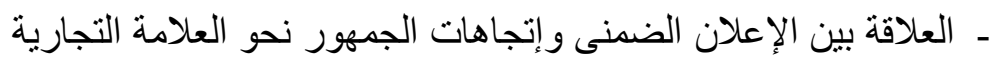

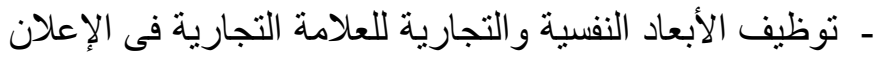

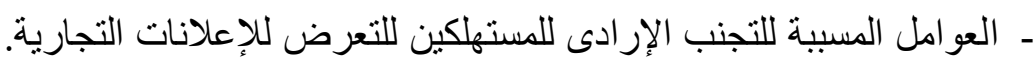

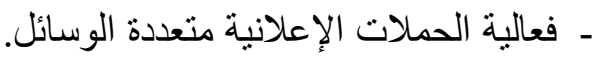

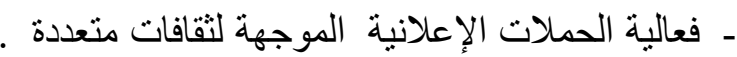

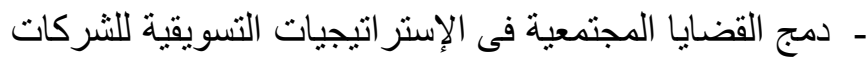

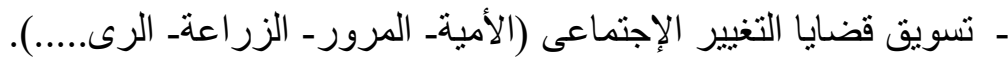

الدراسات التى اجريت فى مجالى الاعلام الاولى و الراى العام:

يمكن تصنيف الموضـوعات التى تناولتهـا الدراسـات التى اجريـت فـى مجـالى الاعلام الاولى و الراى العام الى ما يلى الموضى

(1) دراسات تتناول دور وسائل الاعلام - سواء كل او احد هذه الوسـائل -فى تثكيل

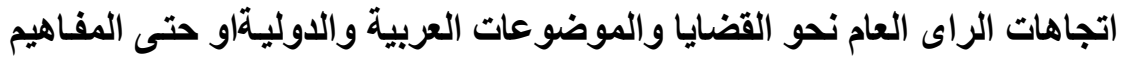

السياسية ووذلك على النحو التالى:14

قضية التطبيع مع اسرائيل:

"اثر الر اديـو و التلبفزيـون في تشكيل اتجاهـات الراى العـام المصـرى نحـو نطبيع

العلاقات مع اسر ائيل (2000)".

مفهوم العولمة الاتصالية :

"دور وسـائل الاعـلام المحليـة و الدوليـة فـى تشكيل المعرفـة لـدى الجمهور فـى ظلـل

العولمة (2002 )".

"دور القنوات الفضـائية فى تشكيل معـارف واتجاهـات الجمهور العربى نحو العولمـة 
بحوث العلاقات العامة والاعلان فى مصر :الواقع واتجاهات المستقبل

:در اسة مقارنة على عينة من الجمهور العام فى مصر وقطر (2005)".

"وسائل الاعلام الدولى وادارة الحوار بين الحضار ات :در اسة تطبيقية (2011)".

"هـل العولمـة امركـة ؟مــركات النخـب الاعلاميـة المصـرية عـن معـاداة الامركـة :در اسة كيفية (2015)".

قضية الصراع العراقى الامريكى:

"الخريطــة الادر اكيـة للـر اي العـام المصـرى تجــاه الصـر اع الامريكـى العر اقـى مـن .2003)2003-1990

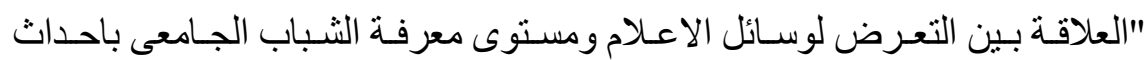

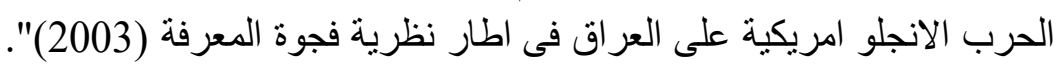
"معالجــة الصـــافة المصـرية لتطــورات الحـرب الانجلــو امريكيـة فــى العـراق ."(2004)

"حـدود الحريـة و المسئولية المهنيـة فـى اداء الثـبكات الاخباريـة الفضــائبة العالميـة

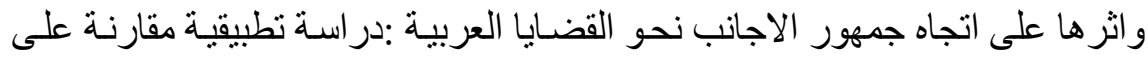

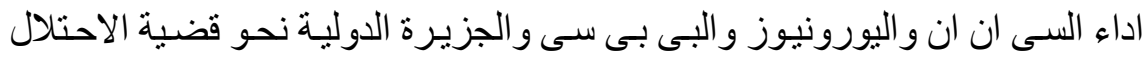

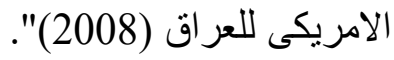

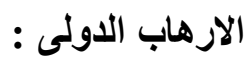

"دور الصـحف المصـرية فـى تشـكيل اتجاهـات الجمهـور المصـرى نحـو قضـية

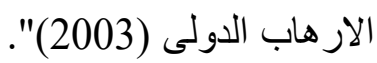

"معالجة الخطاب الدينى لقضية الار هاب الدولى بالصحف المصرية العامـة و الدينية

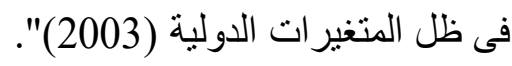

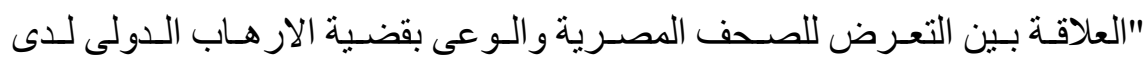

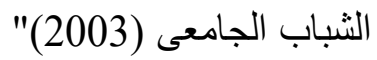

"دور التليفزيون في تشكيل مفـاهيم و اتجاهـات الثباب العربسى نحو الارهـاب :در اسـة كيفية مقارنة بين مجمو عات من الثباب العربى (2003)". 
بحوث العلاقات العامة والاعلان فى مصر :الواقع واتجاهات المستقبل

الحكام العرب ومستوى ادائهم:

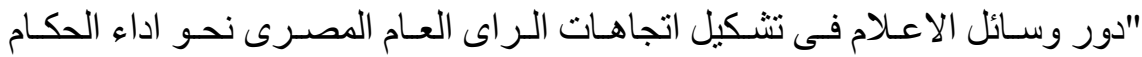

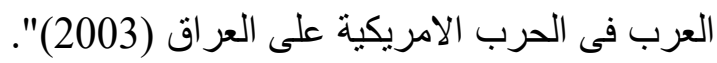

التحول الديمقر اطى فى المنطقة العربية :

"تقييم الصفوة المصرية للتغطية الاعلامية في الصئة الصحافة و التليفزيون لاحداث التحول الديمقر اطى فى المنطقة العربية (2008)".

المنظمات السياسية الدولية والاقليمية:

" دور الاعلام فى تشكيل الصور الذهنية للمنظمات السياسية الاقليمية والدولية لدى الدئ

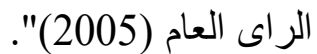

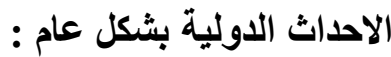

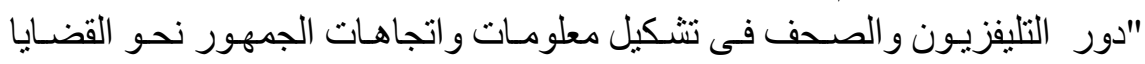

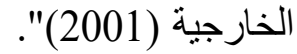

"المعالجة الاعلامية للاحداث الدولية :در اسة على عينة من وسـائل الاعلام المصرية والامريكية (2006)".

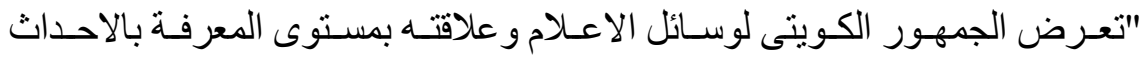

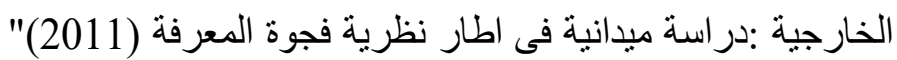

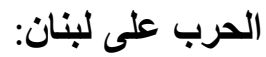

"دور وسـائل الاعـلام فـى نتـكيل معسارف و واتجاهـات الـراى العـام المصـرى نحـو

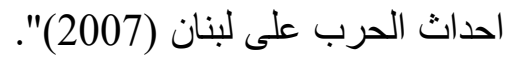

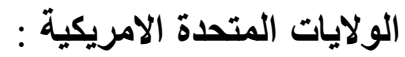

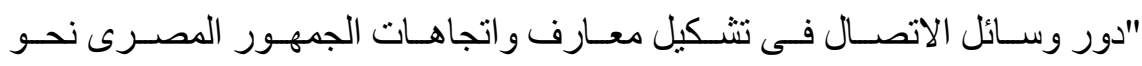
الانتخابـات الرئاسية الامريكيـة 2008در اسـة في اطـار مدخل الاعتمـاد على وسـائل

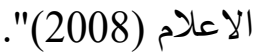

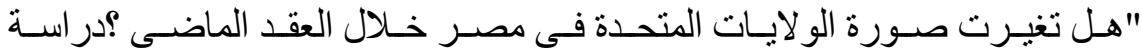

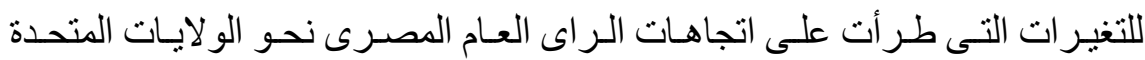
"2009) 2008 -1999

الازمة الاقتصادية العالمية:

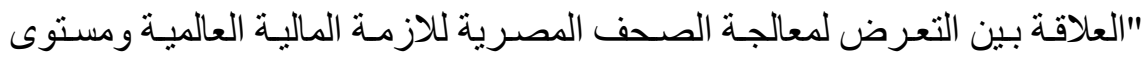
معرفة الجمهور بهذه الازمة واتجاهاتهم نحوها (2009) ". 
بحوث العلاقات العامة والاعلان فى مصر :الواقع واتجاهات المستقبل

قضايا الاصلاح فى المنطقة العربية :

"دور وسـائل الإعلام العربيـة فى تكوين معـارف الصفوة المصـرية و اتجاهاتها نحو

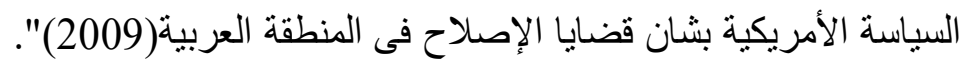

"المعالجـة الإعلاميـة لقضـايا الإصـلاح في المملكـة العربيـة السعودية:در اسـة تحليليـة

ميدانية عن الفترة من 2008/1/1إلى 2008/12/13(2010)"

القضايا النووية :

"اتجاهات الر ايى العام المصرى نحو المعالجة الاعلامية للقضايا النووية (2013)"

العلاقات بين العرب والامريكين:

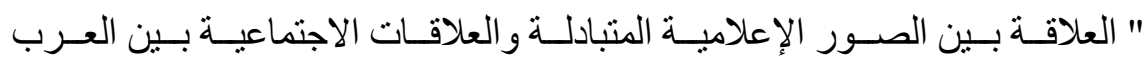

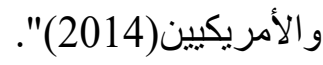

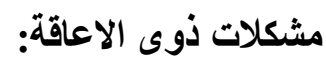

"مثـكلات ذوى الاعاقـة فـى دولــة الامــار ات ودور وســائل الاعـلام فـى نشـرها

حقوق الطقل :

"الاتجاهات الحديثة فى الدراسات المعنية بدور الاعلام التلبفزيونى فى مجال حقوق

الطفل :در اسة مقارنة على المستويين العربى والدولى (2015)".

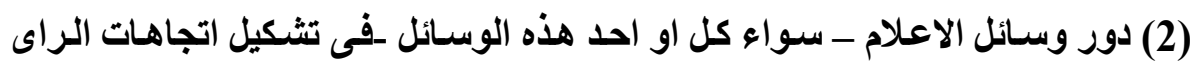

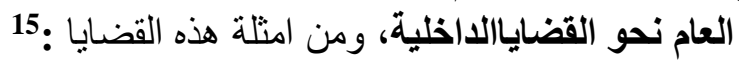

قضية التحول الاقتصادى:

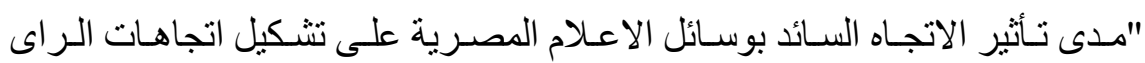

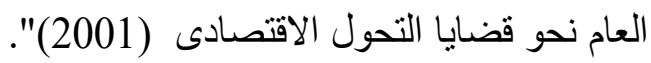

تثغيل قنوات تليفزيونية مصرية غير حكومية:

"اتجاهات الجمهور نحو الفضائيات المصرية الخاصة (2003)". 
بحوث العلاقات العامة والاعلان فى مصر :الواقع واتجاهات المستقبل

القضايا المجتمعية البارزة:

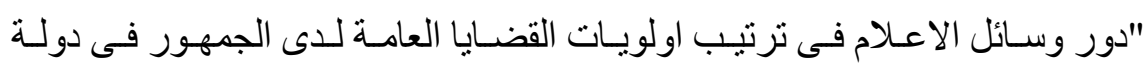

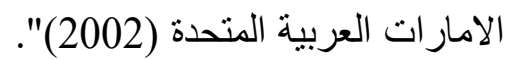

"دور وسـائل الاعـلام و الجماعـات المرجعيـة فـى تنـكيل الاهتمامـات البـارزة للـر اي

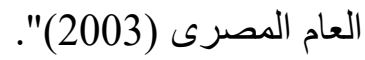

"دور الصـحافة المصـرية فى ترتيب اولويـات القضـايا الخاصـة بـالر ايى العـام الريفىى ."(2008)

"دور وسـائل الاعـلام فـى القضـايا القوميـة :دراسـة تطبيقيـة على عبنـة مـن حمـلات ترشيد السلوك (2016)".

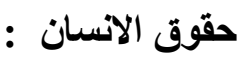

"تأثثير المعالجـة الاعلاميـة لقضـايا حقوق الانسـان على معـارف واتجاهـات الجمهور

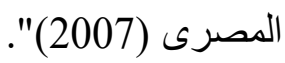

"دور الصـحافة المصـرية في تشكيل اتجاهـات الثباب الجـامعى نحـو قضـايا حقوق الانسان (2010)".

"المعالجـة الاعلاميـة لحقوق المـر أة المصـرية و علاقتهـا باتجاهـات الجمـاهير نحوهـا ."(2016)

$$
\text { الارهاب واحداث العنف: - الع: }
$$

"دور التليفزيون فى تشكيل مفاهيم و اتجاهـات الثباب العربى نحو الارهاب :در اسـة

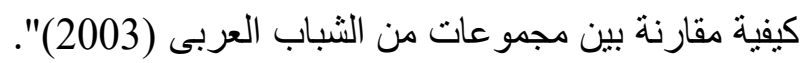

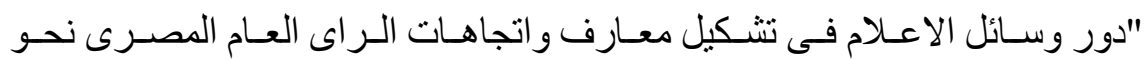
الار هاب :مدخل تكاملى (2003)".

"المعالجـة الإعلاميـة لأحداث العنف وتأثير اتها على الأزمات الاقتصـادية بعد الثورة ."(2015) "اتجاهات المر اهقين نحو دور الافلام السينمائية فى فترة الثور ات العربية ومـا بعدها فى نشر ثقافة العنف وتأثثر اتها (2015)" دور الافلام 
بحوث العلاقات العامة والاعلان فى مصر :الواقع واتجاهات المستقبل

"علاقة التعرض لبر امج الترويع و الخديعة بالاتجاهات العدائية لدى الثباب المصرى ."(2015)

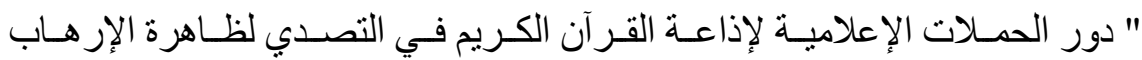

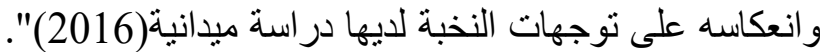

الاصلاح السياسى:

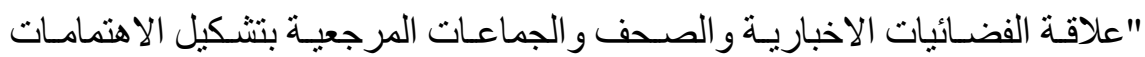

نحو قضايا الاصلاح السياسى لدى الراى العام المصرى (2006 )".

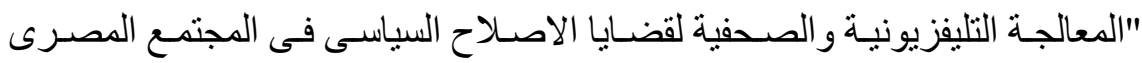
ودورها فى نتكيل معارف الجمهور و اتجاهاته نحوها (2008)".

"العلاقة بين مستويات التعرض للبر امج الحواريـة فى الفضـائيات العربيـة ومستويات

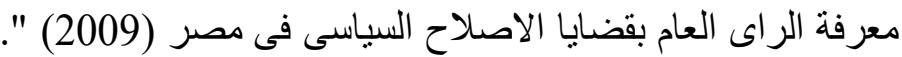

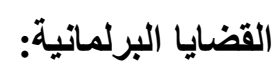

"التليفزيــون كمصـدر لمعرفـة المغتـربين المصــريين بالانتخابـات البرلمانيـة فـى مصر(2002)".

"موقـف الصـحفيين المصـريين مـن تغطيـة وســائل الاعـلام المصـرية للانتخابـات البرلمانية لعام 2005(2006)".

"المعالجـة التليفزيونيـة والصـحفية للقضـايا البرلمانيـة ودور هـا فـى تثـكيل اتجاهـات الجمهور العام نحو البرلمان (2006)".

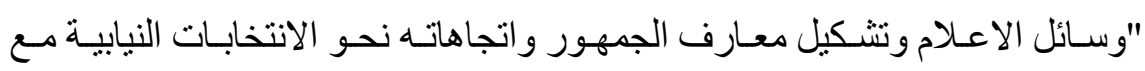
التطبيق على الانتخابات الاردنية (2013)".

" العلاقـة بين أداء وسـائل الإعـلام أثنـاء الانتخابـات البرلمانيـة 2010 وقرار الناخب البـا "در اسة تطبيقية (2014)".

الاتتخابات الرئـاسية :

"اتجاهـات المعالجـة الصـحفية لحملــة الانتخابـات الرئاسـية و اثر هــا علـى معـارف و اتجاهات الناخبين (2005)". 
بحوث العلاقات العامة والاعلان فى مصر :الواقع واتجاهات المستقبل

"اتجاهـات الر اى العـام المصـرى نحو التغطيـة الاعلاميـة للانتخابـات الرئاسية لسـنة 2014:در اسة مسحية (2014)". التعديلات الاستورية:

"التغطية التليفزيونية للتعديلات الدستورية و علاقتها باتجاهـات الراى العام المصرى نحو شرعية النظام السياسى (2008)".

القضايا النووية : n

"دور وسائل الاعلام فى تكوين وعى وادر الك الصفوة المصرية تجاه القضايا النووية (2007)"

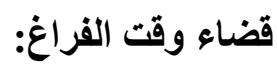

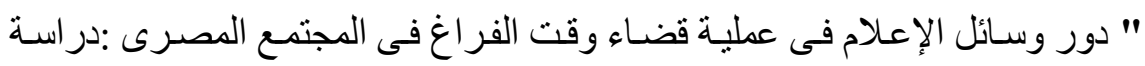

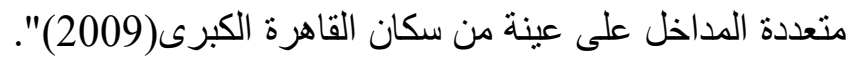

\section{الهوية الوطنية :}

"دور الفضــائيات العربيـة فـى دعـم الهويـة الوطنيـة :رؤيـة مـن و اقـع مجتهـع دولــة الامار ات العربية المتحدة فى سياق مدخل بناء المعنى (2011)".

$$
\text { الهجرة السرية والاداء الحكومى بشأنها: }
$$

"اتجاهـات الـر ای العـام نحو معالجـة القنوات التلبفزيونيـة المصـرية لقضـية الهجـرة السرية والاداء الحكومى بثأنها فى اطار النظرية اللبنانية للراى العام (2010)".

قضايا الفساد بعد ثورة 25 يناير 2011:

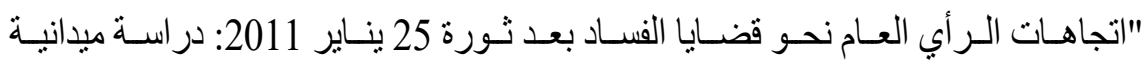
."(2012)

قضايا التحولات والانقسامات السياسية في مصر فى الفترة ما بعد 25 يناير:

"تقييم رؤية المواطن المصرى تجاه تغطية وسـائل الاعلام لازمـة المجلس العسكرى و اقباط ماسبيرو خلال عام 2011(2012)".

"دور وسائل الإعلام في تشكيل معارف و اتجاهـات المغتربين المصريين نحو قضـايا التحول السياسـي في مصر للفترة مـا بعد 25 يناير : در اسـة في إطسار نظريـة المجـال

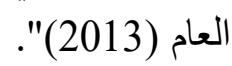


بحوث العلاقات العامة والاعلان فى مصر :الواقع واتجاهات المستقبل

"اتجاهـات الر ایى العـام نحـو الانقسـامات السياسية فـى مصـر :استطلاع للـراى العـام

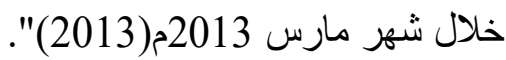

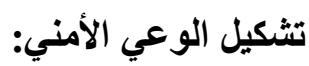

"دور وسائل الإعلام في نشر الوعي الأمنـي لدى الجمهور الكويتي "دراسـة ميدانية

تحليلية (2013 )".

الايمقر اطية: - n

"تقييم الصفوة الأكاديمية للدور المجتمي لوسائل الإعلام المصرية في إطار نظريـة

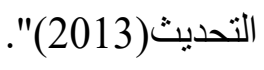

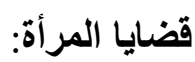

"اخـتلاف المعرفـة المكتسبـة مـن وسـائل الاعـلام بـين الجمهور المصـرى :بـالتطبيق

$$
\text { على العنف ضد المرأة (2007)". }
$$

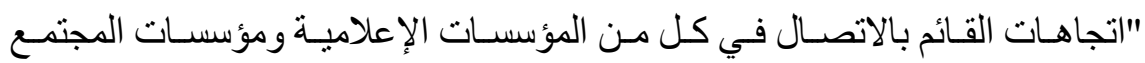

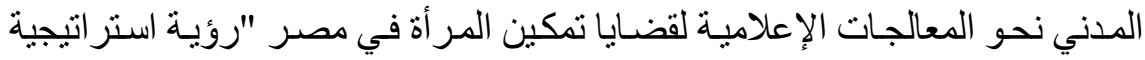
في ضوء مدخل التسويق الاجتماعي (2012)".

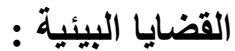

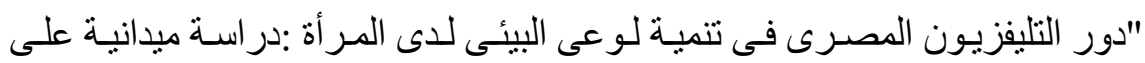

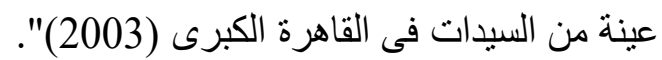
"دور التليفزيون فى ادراك الجمهور لمخاطر التغير ات المناخية على مستقبل الحياة فى مصر (2011)". "التعرض للصحف المصرية و علاقته بمسنتوى المعرفة بازمـة الميـاه للدى عينة من القراء (2011)".

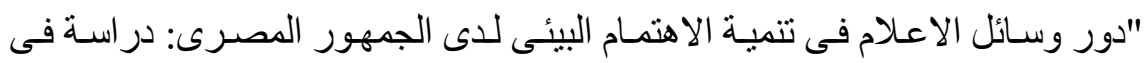
اطار نظرية الاعتماد على وسائل الاعلام (2015)".

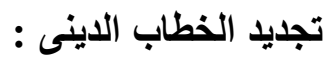

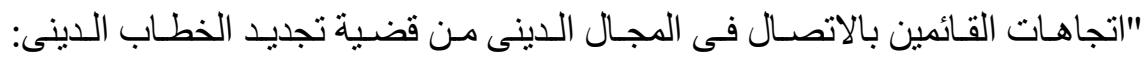
دراسة الميدانية (2014)". 
بحوث العلاقات العامة والاعلان فى مصر :الواقع واتجاهات المستقبل

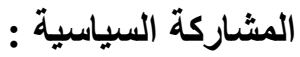

"دور التليفزيون فى دعم المشاركة السياسية لدى الجمهور المصرى بالتطبيق على الانتخابات الرئاسية 2012(2014)".

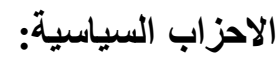

"دور الاعلام في تشكيل معـارف واتجاهـات الثباب نحو الاحز اب السياسية وهويـة

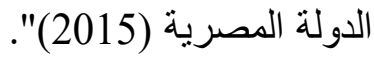

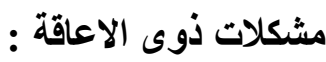

"مشـكلات ذوى الاعاقـة فـى دولــة الامـــار ات ودور وســائل الاعـلام فـى نشـرها

(3) وحديثا فى نفس هذا الاطار تناولت بعض الدراسـات مجموعة من المتغيرات ذات

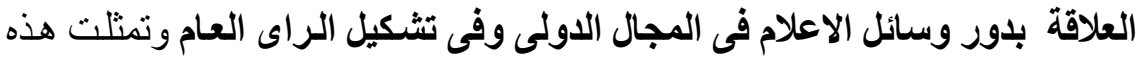

16 : العو امل فى لـى

تكنولوجيا الاتصال الحديثة:

"تأثير تكنولوجيا الاتصال الحديثة على التنظيم فى المؤسسات الاعلامية (1996)".

التخطيط الاعلامى :

" التخطيط الاعلامسى فـى وسـائل الاعـلام العربيـة الموجهـة الـى المغتربين العـرب

."(1997)

العلاقات الاجتماعية : - الع

"العلاقـة المتبادلـة بـين التعـرض المشـترك لوســائل الاعـلام والعلاقـات الاجتماعيـة

" العلاقة بين التعرض للبر امج الحواريـة حول الأحداث الجاريـة (توك شو ) ومستوى

الإحباط الاجتماعى(2009)".

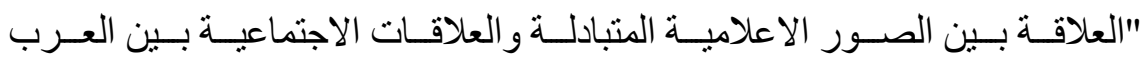

$$
\text { والامريكيين :دراسة مسحية (2014)". }
$$


بحوث العلاقات العامة والاعلان فى مصر :الواقع واتجاهات المستقبل

مستوى الرضا الوظيفى للعاملين واتجاهاتهم :

"العو امـل المـؤثرة علـى الرضــا الـوظبفى لـــى العـاملين فـى المؤسســات الاعلاميـة

"محددات الرضا الوظيفى لدى العاملين فى القنوات الفضائية المصرية (2002)".

"مشكلات الاعلاميات فى الاذاعة والتليفزيون الاردنى (2008)".

"اتجاهـات الاعلاميين المصريين نحو اعـادة هيكلة اعلام الدولة بعد ثورة 25 يناير

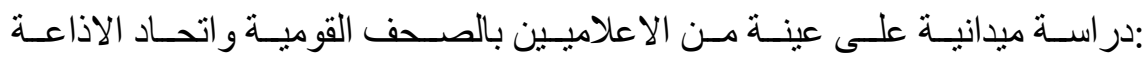

والتلبفزيون (2012)".

"الرضا الوظيفى لدى القائم بالاتصـال فى الصحف اليوميـة الاردنية :در اسـة مسحية

"تصـور ات الاعلامينين فـى وسـائل الاعـلام الاليكترونيـة الامار اتيـة لادوار هم المهنيـة و العوامل المؤثرة فيها (2013)".

"رؤيـة القـائمين بالاتصـال فـى مصـر نحـو مفهوم التنـوع ع الاعلامسى واليـات تطبيقهـه "در اسة كيفيه (2016):

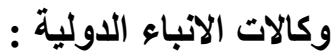

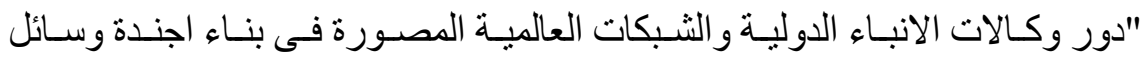
الاعلام المصرية بالنسبة للاخبار و القضايا الخارجية (2001)".

دوافع الاستخدام والاشباعات المتحققة :

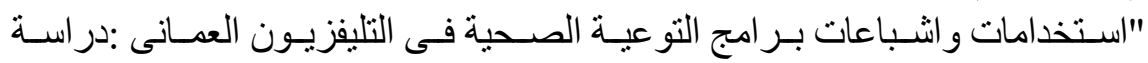
تحليلية وميدانية(2004)"

"استخدامات الجمهور فى مملكة البحرين لوسائل الاعلام و الاشباعات المتحققة منها ")

"دو افع استخدام الصفوة الثقافية للوسائل الاعلامية المتخصصـة والاشباعات المتحققة

لهم :دراسة ميدانية (2006)".

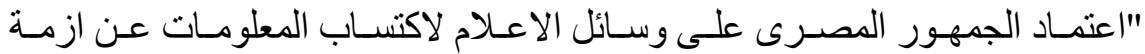
انفلونزا الطيور (2007)". 
بحوث العلاقات العامة والاعلان فى مصر :الواقع واتجاهات المستقبل

"استخدامات الاطفال ساكنى احواش المقابر لوسـائل الاعلام و الاشباعات التى تحققها لهم (2007)".

"اســتخدامات الثــباب الامــار اتى للقنـوات الفضــائية الغنائيــة العربيـة و الاثــباعات

المتحققة (2008)".

"استخدامات الثباب النوبى لوسـائل الاعلام المصـرية و الاشباعات التى تحققها لهم :در اسة ميدانية (2009)" (10)

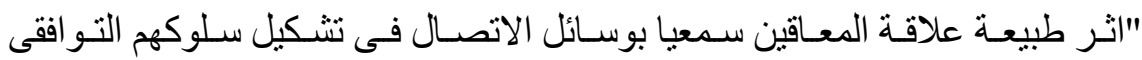

."(2009)

"اعتمـاد سـائقي التاكسي علي وسـائل الإعلام المصرية في الحصـول علي معلومـات

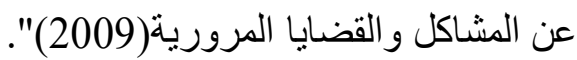

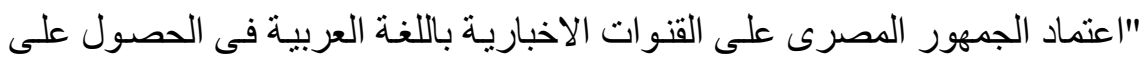
المعلومات حول الاحداث الجارية (20009)".

"اسـتخدام الثـباب الكويتى المغترب بمصـر لمو اقـع الصـحف الكويتيـة والاشباعات المتحققة منها :در اسة ميدانية (2011)".

"اعنماد الجمهور المصرى على القنوات الفضـائية الاخباريـة فى متابعة احداث ثورة 25 يناير وتطور اتها(2012)".

" اعتمـاد الجمهور البحرينـي على وسـائل الإعـلام المحليـة كمصدر للمعلومـات عن المن القضايا والاحداث السياسية

."(2016)

"اعتمـاد النخبـة على وسـائل الاعـلام الكويتيـة للتـزود بالمعلومـات حـول القضــايا السياسية الداخلية و الخارجية: دراسة ميدانية (2016)"

"اتجاهـات الجمهور نحو المـواد الاعلاميـة المسيئة للاديـان ووسـائل الاعـلام المقدمـة لها :در اسة ميدانية (2016)".

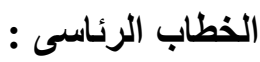
" دور الخطاب الرئاسي في بناء أجندة وسائل الإعلام والصفوة المصرية(2010)" 
"المســـولية الاجتماعيـة للبـر امج الحواريـة التليفزيونيـة البوميـة فـى تتــاول الاداء الحكومى: در اسة تحليلية (2009)". "معايير الحكم الرشيد لدى وسـائل الاعلام المصرية: در اسـة تطبيقية على عينة دـن الصحف القومية و الحزبية و المستقلة (2012)". "المسئولية الإجتماعيـة لوسـائل الإعـلام كأحد معـيير الحوكمـة الإعلاميـة فـى مصـر :

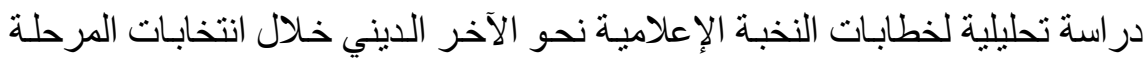
الإنتقالية لعام 2011- 2012 فى ضوء تصور اتهم لقيم الإعلام الرشيد(2013)" الإنيات

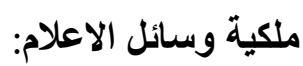
"انماط ملكية وسائل الاعلام و علاقتها بالممارسة المهنية (2014)". " العلاقـة بـين ملكيـة وسـائل الإعـلام ومعالجتهـا لقضـايا التحـول الـديمقر اطي وصـنع

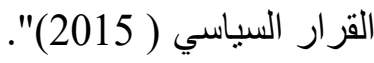

\section{حرية الاعلام ومصداقيتها :}

"مستويات مصداقية وسـائل الاعلام المصرية لدى الجمهور : در اسـة كمية /كيفية فى الفى

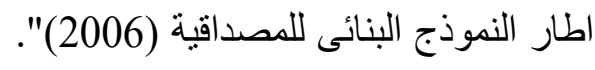
"العلاقة بين حرية الاعلام وهيبة القضاء(2015)".

"الثبـات و التحـول فـى الخطـاب الصحفى و الاعلامسى عقب ثنورة 25 ينـاير و علاقتهـ بالمصداقية(2015)".

مجمـل العوامـل المـؤثرة على دوروسـائل الاعـلام ـاو احــ هذه الوســائل ـ فـى المجـال

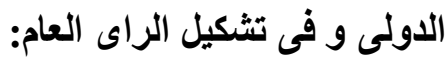

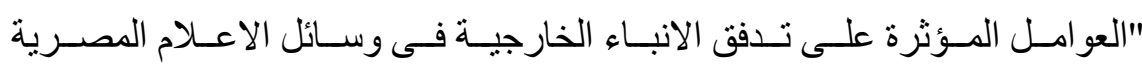
."(2008)

"العو امل المؤثرة فى بناء اجندة الصحافة اليمنية :دراسة مقارنة (2010)" "العو امل المؤثرة على ثقة النخبة فى وسائل الاعلام المصرية بعد الثورة (2011)". 
بحوث العلاقات العامة والاعلان فى مصر :الواقع واتجاهات المستقبل

(4) فى اتجاه موازى تناولت بعض الدراسـات تأثثير احد القوالب القنية بوسـائل الاعلام

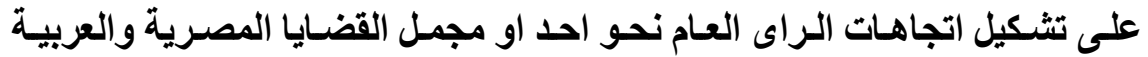

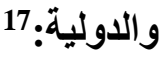

ومنها برامج الراى وبرامج الحوار :

"تعرض الصفوة المصرية لبر امج الراى فى القنوات التليفزيونبة العربية (2003)".

"دور البر امج الحواريـة فى التليفزيون المصرى فى تشكيل اتجاهـات الجمهور نحو

التعديلات الدستورية (2008)".

"دور بـر امج الحوار التلبفزيونيـة (التوك شـوز) المقدمة بـالقتوات الحكوميـة والخاصـة فى تشكيل اتجاهـات الجمهور المصرى نحو المشـاركة السياسبة بعد ثورة 25 بنـاير

."(2012)

"الخطاب الاعلامى للقوى السياسية فى البر امج الحواريـة بالفضـائيات :در اسـة تحليلية

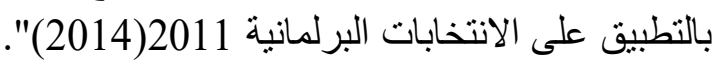

"العلاقـة ببين التعرض للبر امج الحواريـة فى التلبفزيون و الهويـة الثقافية لدى الثباب العربى (2014)".

" العلاقـة ببن التعرض لبر امج الحوار التلبفزيوني و اتجاهـات الثباب الجـامعي نحو ثقافة السلام(2015)".

القتوات والنشرات الاخبارية:

"دور نشـرات الاخبـارفى القنـوات الفضـائية في ترتيب اولويـات الجمهور المصـرى نحو القضايا المصرية والعربية والدولية(2006)".

"اسـتخدام الجمهور فـى دولـة الامـار ات العربيـة المتحـدة للقنـوات الاخباريـة العربيـة وتأثثرها على اتجاهاتهم نحو القضايا العربية (2008)".

"اعتماد الجمهور المصرى على القنوات الإخبارية باللغة العربية فى الحصول على المعلو مات حول الأحداث الجارية(2009)".

"دور القنـوات الاخباريـة العربيـة فـى تشكيل صـورة مصـر لـدى الجمهور العربـى ."(2011) 


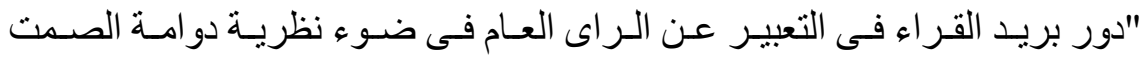

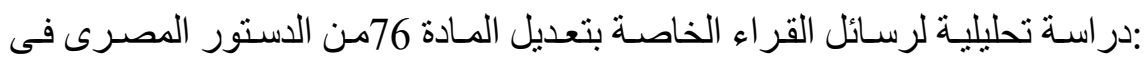
صحيفة الاهر ام خلال عام 2005 (2006)".

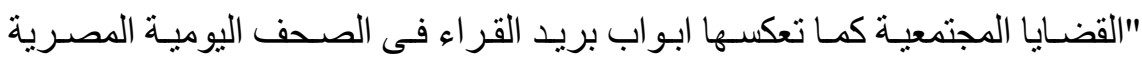

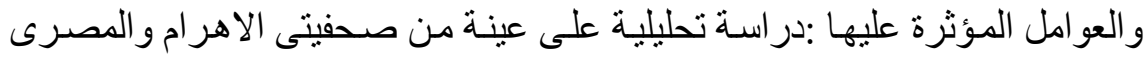

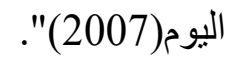
اغانى القيديو كليب:

" صورة الثورة كما تعكسها أغاني الفيديو كليب الوطنية و علاقتها بصورتها الذهنية

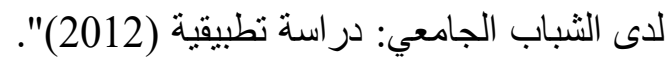

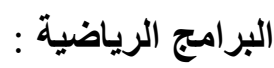

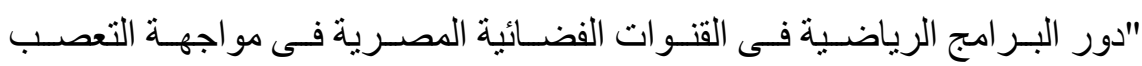

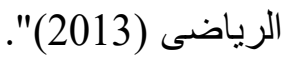

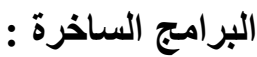

"العلاقة بين التعرض للبر امج التلبفزيونية السـاخرة واتجاهـات الراى العام المصرى نحو مؤسسات الدولة (2015)".

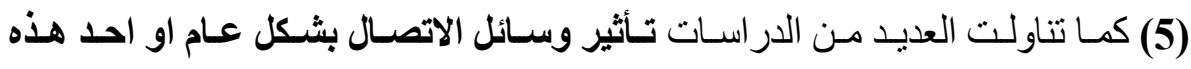

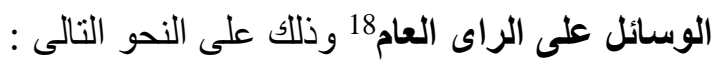

بدأت تلك الدراسـات بما يلحى "دور الاتصـال فى انتشـار المستحدثات :در اسـة تطبيقية

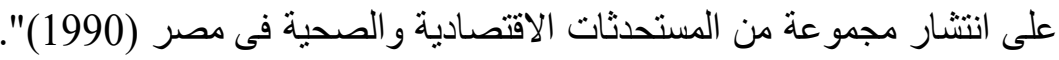

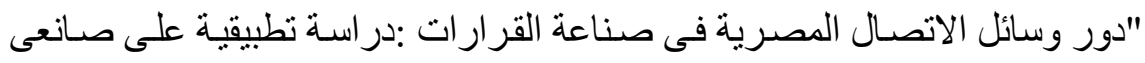

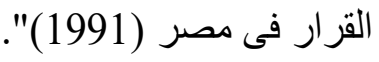

"دور الاتصــال فـى عمليـة المشـاركة السياسـية والاجتماعيـة والاقتصـادية :دراســة تطبيقية مقارنة على قريتين مصريتين (1991)".

"تـأثير وسـائل الاتصـال على تنظيم الاسـرة فـى الريـف المصـرى :در اســة ميدانيـة مقارنة على قريتين مصريتين (1991)". 
بحوث العلاقات العامة والاعلان فى مصر :الواقع واتجاهات المستقبل

"دور الاتصـال فـى التنميـة السياسـية :در اسـة ميدانيـة مقارنـة على قريتين مصـريتين

"العلاقــة بـين التعـرض لوســائل الاتصــال وطبيعـة الاتجـاه نحــو مشـكلة الار هـاب

"الاتصـال الثخصـى فـى المجتمعـات العربيـة :در اسـة ميدانيـة على كفاءة الافر اد فـى المحادثات الاجنماعية (1993)". "دور الاتصال فى تتمية المجتمعات المحلية (1995)".

"دور الاتصال المباثر فى تتمية الوعى الاجتماعى :دراسـة ميدانية للنشاط الاتصسالى

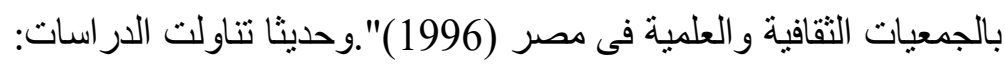

"دور الاتصـال فى المشاركة السياسية للمر أة المصرية (2000)"

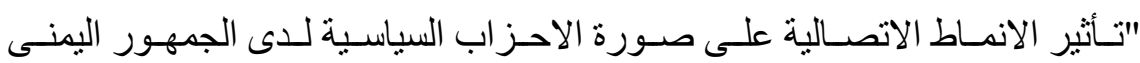

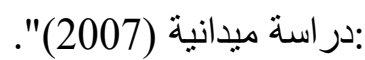

"دور الاتصال فى اثباع الحاجات الاجتماعية للجمهور المصرى (2007)" "الاتصـال وثقافـة الحـوار :دراسـة مسـحية على عينـة من طـلاب جامعـة الملك عبد

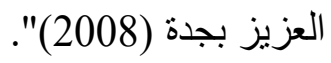

"تأثثر كل من الاتصـال الجماهيرى و الثخصـى على الانتمـاءات الحزبيـة والششـاركة

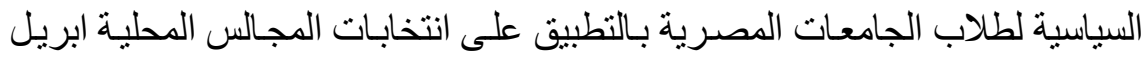
2008:در اسة مسحية على عينة من طلاب جامعة القاهرة (2008)". "دور وسـائل الاتصـال فى تشكيل معـارف الجمهور السـودى نحو قضـايا الارهـاب :در اسة مسحية (2008)".

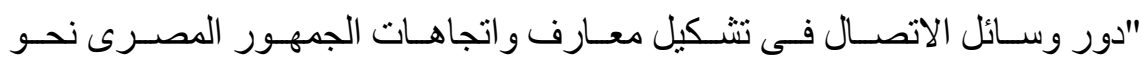
الانتخابات الرئاسية الامريكية (2008)".

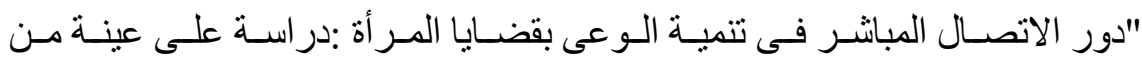

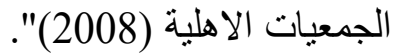
"دور قنوات الاتصـال المباشـر فى تشكيل اتجاهـات وسلوك النـاخبين المصريين نحو

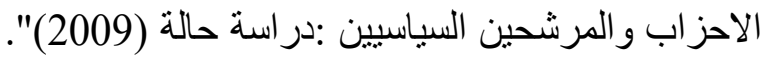


بحوث العلاقات العامة والاعلان فى مصر :الواقع واتجاهات المستقبل

"دور وسـائل الاتصـال فـى تتميـة وعـى الثـباب الكويتى بقضـية المخدر ات :در اســة ميدانية (2010)".

"دور وسـائل الاتصـال فى تشكيل معسارف الجمهور المصرى نحو القضـايا الصـية

") (2010)

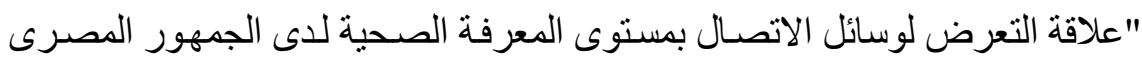

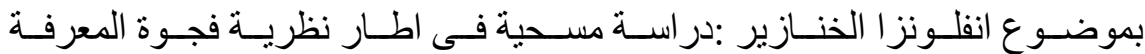
."(2010)

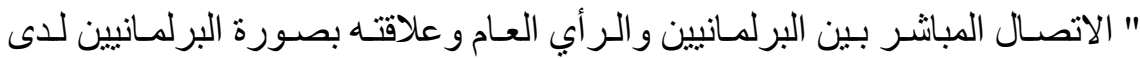
الجماهير :در اسة ميدانية (2012)".

" دور الاتصـال المباشـر في تدعيم المشـاركة التطو عية لدى الثباب دراسـة تطبيقيـة

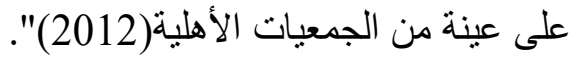

"دور الدعاية الانتخابية في تفعيل المشاركة السياسية في اليمن ( 2013)". " تقيـيم دور الانثــطة الاتصــالية فـى نثــر ثقافـة الجـودة الثــاملة :در اسـة حالــة ."(2014)

"دور الانشطة الاتصالية فى نشر الوعى بقضايا حقوق الانسان :در اسـة تطبيقية على العى

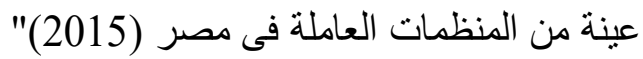

(6) تناولت بعض الدراسات الاتجاهات الحديثة فى بحوث الراى العام ومنها: 19 "الاتجاهات العالمية الحديثة فى بحوث ودراسات الراى العام (2004)".

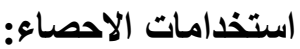

"استخدامات الاحصاء فى دراسـات الراى العام وقياساته :تحليل من المستوى الثنانى ."(2002)

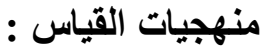

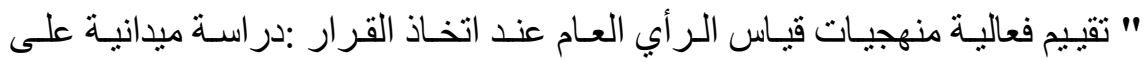

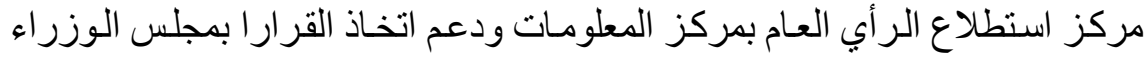
."(2012) 
بحوث العلاقات العامة والاعلان فى مصر :الواقع واتجاهات المستقبل

"التحول في مفهوم المتلقي في الدراسـات الإعلامية المصرية خلال الفترة من 1978

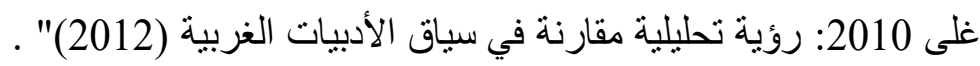

"ادوار مر اكز استطلاعات الـراى ووظائفهـا فـى المجتمعـات المعاصـرة :فى اطــار

التحليلين البنائى و النقدى لانظمة المجتمع الفرعية (2015)".

المحددات ثقافية وتكنولوجية:

"تأثير المحددات الثقافية والتكنولوجيـة على بحوث الر أي العام "در اسـة تطبيقيـة في الإي

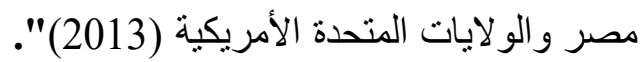

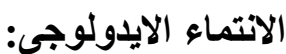

"تـأثبر الانتـــاء الايــلوجى على الاتجاهـات التصــوينتية فـى الانتخابـات الرئاسـية المصرية 2012 (2015)".

ومن الدراسات الحديثة ايضا الدر اسة التى تتناول:

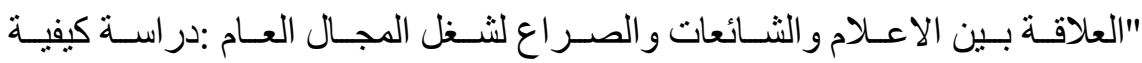

(7) تناولت بعض الدراسات نظريات وظواهر فى الراى العام: 20

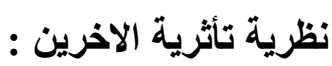

"نظريـة تأثريـة الاخرين فى دراسـات الراى العـام: اسسـها النظريـة وبعض تطبيقاتها فى المجتمع المصرى (2002)"

نظرية بناء الاجندة : مبن

"علاقات التفاعل بين العوامل المؤثرة فى بناء اجندة قضـايا الراى العام فى الصحف المصرية :در اسة فى اطار بناء الاجندة (2002)".

نظرية تحليل الاطر الاعلامية:

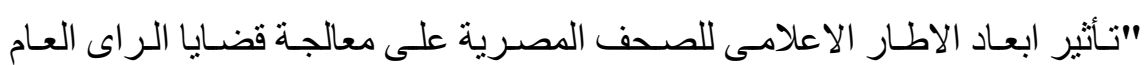

:در اسة فى اطار نظرية تحليل الاطر الاعلامية (2003)".

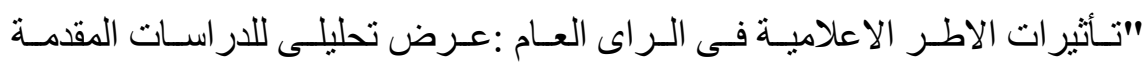

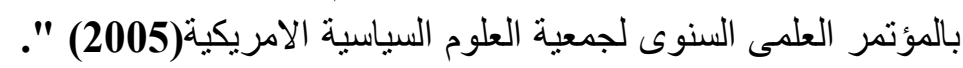


بحوث العلاقات العامة والاعلان فى مصر :الواقع واتجاهات المستقبل

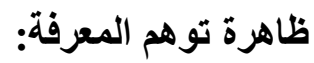

"وسـائل الاعـلام و علاقتهـا بظـاهرة تـو هم المعرفـة فـى استطلاعات الر اى العـام فىى

مصر (2002)" (1020)

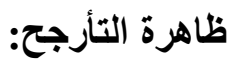

"التليفزيون و علاقته بظاهرة التارجح فى اتجاهات الراى العام فى مصر (2004)".

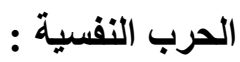

"الحرب النفسية :در اسـة نظريـة تطبيقية على اسـاليب الحرب النفسية الامريكية ضد

$$
\text { العر اق(2007)". }
$$

الشائعات:

"اتجاهـات الراى العـام المصـرى نحـو ثنائيـة الاعـلام و الثــائعات :فى اطـار التحليل

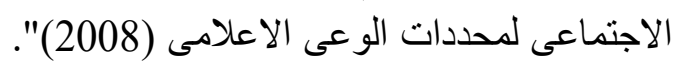

التعليق على العرض السابق من حيث :

القترات الزمنية التى تركز فيها الاتتاج العلمى فى مجال الراى العام:

تتميز دراسات الر ايى العام العربية بالوفرة والحداثة حيث:

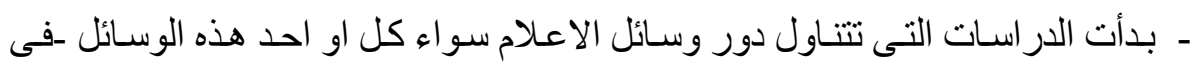

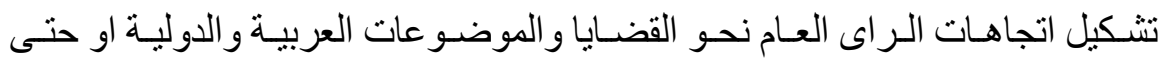
المفاهيم السياسية فى عام 2000ومستمرة حتى الان.

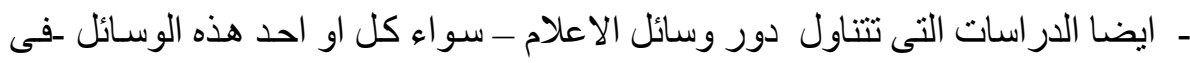

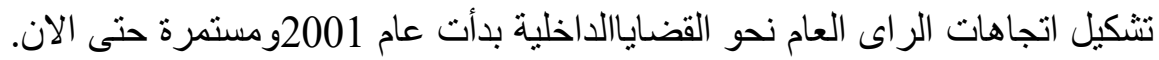
- و وبالمثل الدراسـات التى تنتـاول العو امل المؤثرة على بحوث الر ايى العـام وهى عدد

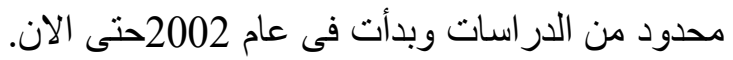

ـ محدوديـة الدر اسـات التـى تتناولت تطبيقـات بعض النظريـات و ظـواهر الـراى العـام وبدأت فى عام 2002-حتى 2008.

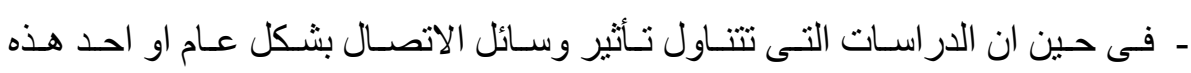

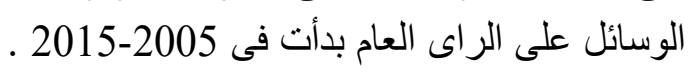


ـ ـ اما الاتجاهـات الجديدة فى در اسـات الراى العام فبدأت فى عام 2012 ومستمرة حتى

من حيث نوع ومنهج الدراسات :

معظم الدراسـات تنتمى الـى الدراسـات الوصفية التى تصف الظو اهر وتبحث عن

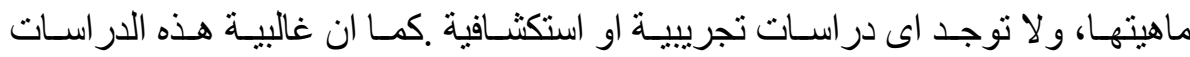

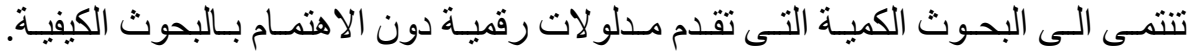

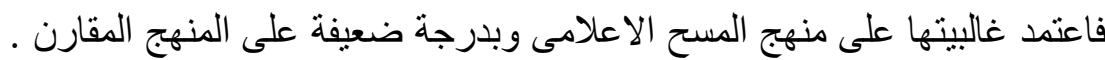
من حيث ادوات جمع البيانات ومجتمع وعينة الدراسة :

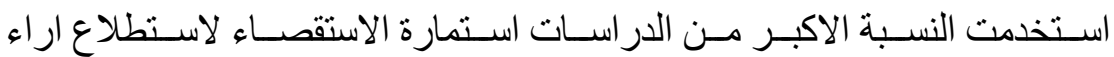

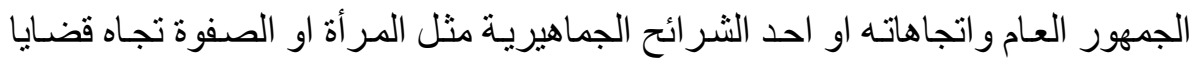

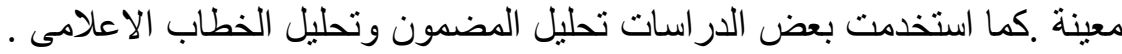
محاور الرويـة المستقبلية المقترحة لتطوير الاراسـات العربية والمصرية خاصـة فى العى

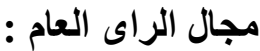

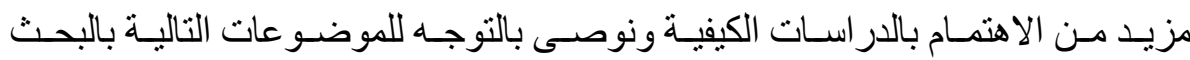

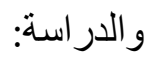
- وسائل الإتصال وصيانة الهوية الوطنية :المسئوليات المشتركة.

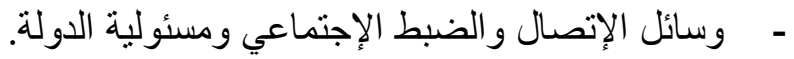

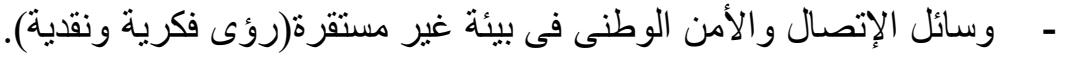

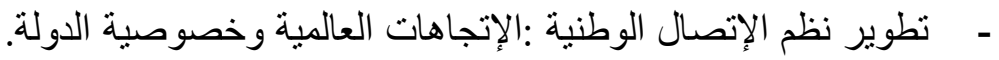

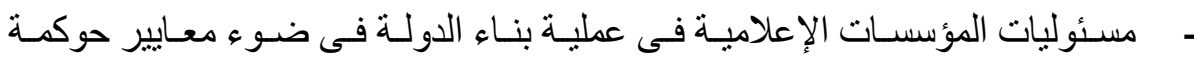

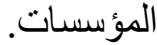
- وسائل الإتصال وبناء نظام قيمى جديد.

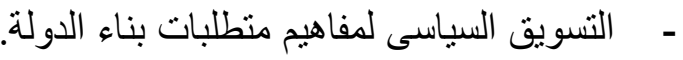

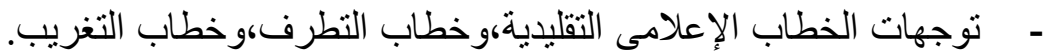

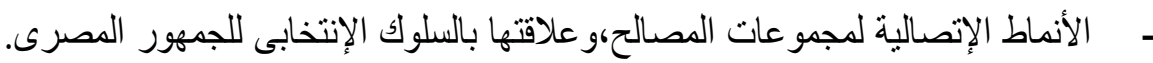

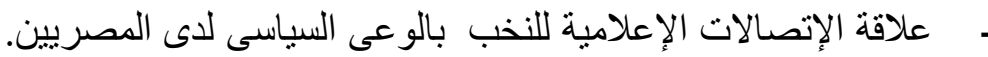
- - - تأثير الإعلام على الهوية الوطنية.

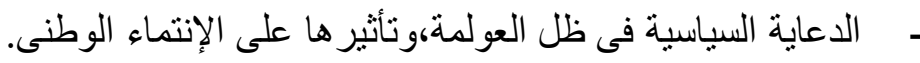


بحوث العلاقات العامة والاعلان فى مصر :الواقع واتجاهات المستقبل

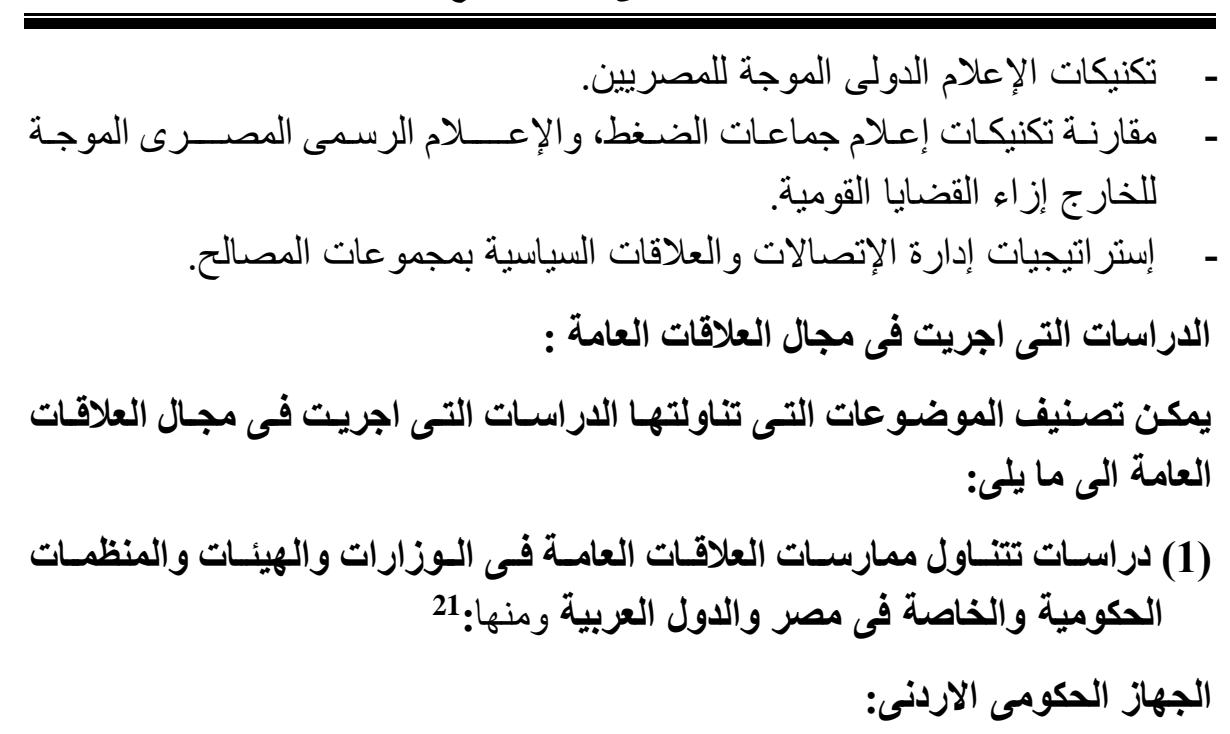

"تتظيم وادارة العلاقات العامـة فى الجهاز الحكومى الاردنى و اتجاهـات الادارة العلبا

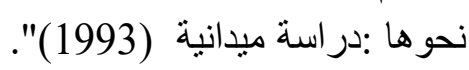
منظمة التحريز القلسطينية: "الوظيفة الاتصالية لمنظمة التحرير الفلسطينية (1996)".

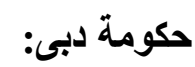
"تقـويم فعاليـة اداء العـاملين فـى مجـال العلاقـات العامـة :در اسـة حالـة بلديـة دبـى "1998) " العلاقـة بـين ممارسـي العلاقـات العامـة ووســائل الإعـلام در اســة علـى المؤسسـات الحكومية في إمارة دبي(2014)".

اجززة الحكومة السعودية:

"دور العلاقات العامة في المؤسسـات الحكومية فيى المملكة العربية السعودية :در اسـة

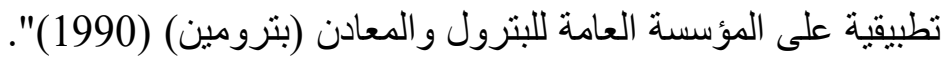
"دور العلاقـات العامـة فـى الاجهـزة الحكوميـة بالمملكـة العربيـة السـعودية :در اســة وصفية (2008)".

"الوظيفة الاتصـالية للعلاقات العامـة فى قطاع الامن السعودى :در اسـة تطبيقية على لى قضية المخدر ات (2008)". 
بحوث العلاقات العامة والاعلان فى مصر :الواقع واتجاهات المستقبل

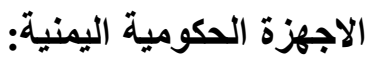

"دور العلاقات العامة فى الاجزةة الحكومية فى الجمهورية اليمنية (2004)" .

وزارة الاخلية المصرية :

"دور العلاقـات العامسة فـى تطبيـق المعاملــة العقابيـة :در اسـة تطبيقيـة علـى الجهـات

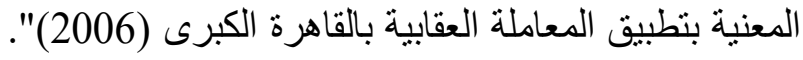

وزارة التربية والتعليم بجمهورية مصر العربية :

"العلاقـات العامـة التربويـة :در اســة للـدور الاعلامسى لممارســى العلاقـات العامــة التربوية بوزارة التربية والتعليم (2007)".

وزارة العمل بالامارات العربية:

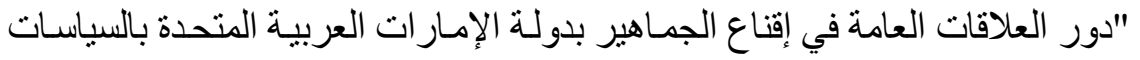
الجديدة لوزاة العمل: دراسة ميدانية(2012)".

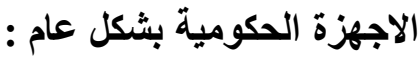

"مدى اعتمـاد الصحفيين على اجهزة العلاقات العامـة بالمنظمات الحكومية كمصـادر

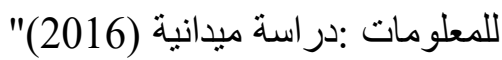

(2) الاراسات التى تتناول ممارسات العلاقات العامة في مختلف القطاعات الخدمية في

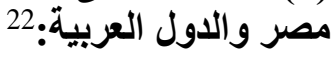

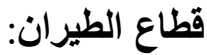

"دور العلاقـات العامـة فـى تحقيـق الرضـا الـوظيفى :در اسـة تطبيقيـة على العـاملين

بالخطوط السعودية (1998)" العاته

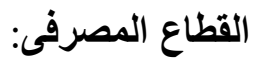

"الوظيفـة الاتصـالية للعلاقـات العامـة فـى الجهـاز المصـرفى :در اســة تطبيقيـة مقارنــة على عينة من البنوك فى مصر (1994)".

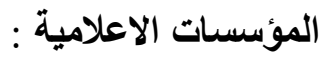

"اهداف ووظائف العلاقات العامة فى المؤسسات الصحفية فى مصر (1991)".

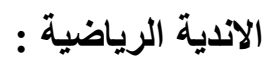

"نموذج مقترح لادارة العلاقات العامـة بالانديـة الرياضية بالمملكة العربية السعودية

."(2011) 
بحوث العلاقات العامة والاعلان فى مصر :الواقع واتجاهات المستقبل

23 وانفردت احد الدراسات بتناول ممارسات العلاقات العامة فى خدمة الافراد "العلاقات العامة فى خدمة المرشح السياسى (2000)".

24: العوامل المؤثرة على ممارسة العلاقات العامة بالمنظمات ومنها در اسات تتاولت مجمل العوامل المؤثرة على ممارسة العلاقات العامة: "العو امل المؤثرة على ممارسة العلاقات العامة فى الثركات الليبية (2006 ).

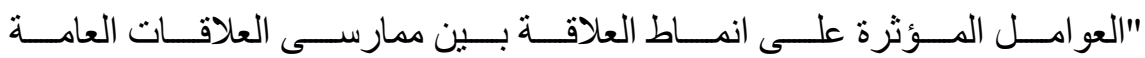
و الصحفيين:در اسة تطبيقية (2011)".

فى حين ركزت بعض الاراسات على عوامل بعينها تؤثر على ممارسة العلاقات العامة مثل : الوظائف الادارية بالمنظمات:

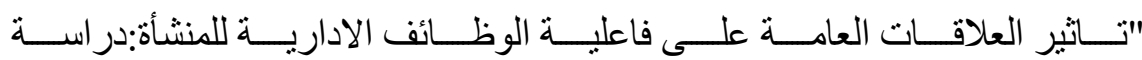
تحليلية(1995)"

"فعاليـة التخطبط الاسـتر اتيجيى فـى تنميـة وتطـوير راس المسال البشـرى فـى اقسـام الاعلام بالجهاز الادارى لسلطنة عمان :دراسة ميدانية (2015)".

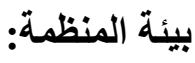

"تاثير بيئة المنظمـة على السـلوك الاتصـالى لجهاز العلاقـات العامـة :در اسـة ميدانيـة تحليلية (2003)". العولمة : 2 الموة

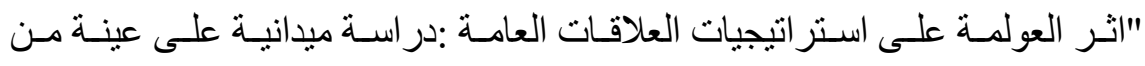

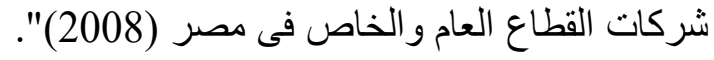

نماذج ممارسة العلاقات العامة وادوار ممارسيها:

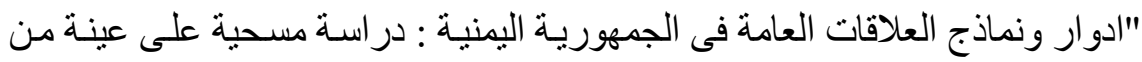
أجززة العلاقات العامة فى القطاعين العام والخاص العلاف (2009)".

" نماذج ممارسة العلاقات العامة في المؤسسـات الحكومية العربية در اسـة على عينة من المؤسسات المصرية و البحرينية (2015)". 
بحوث العلاقات العامة والاعلان فى مصر :الواقع واتجاهات المستقبل

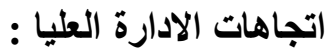

"تأثنير اتجاهـات الادارة العليا علي الأداء المهني لعلاقات العامـة : در اسـة علي عينة من شركات الطاقة" (2013)".

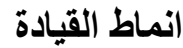

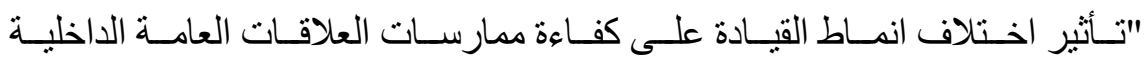

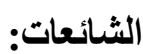

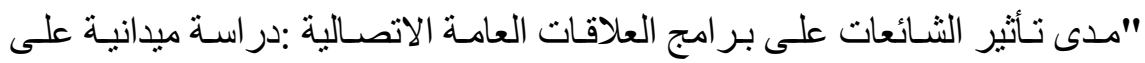

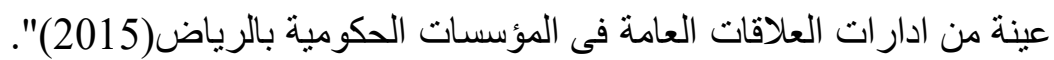

الرضا الوظيفى : - (الر

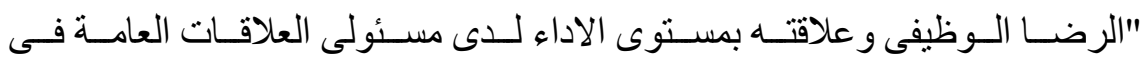

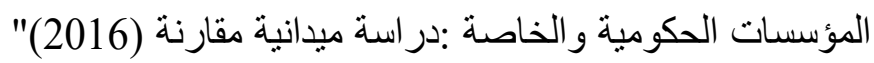

وتطرقت دراسات اخرى الى العوامل المؤثرة على الرضا الوظيفى للممارسين انفهه:

"العو امل المؤثرة فى الرضا الوظيفى لدى العاملين بالعلاقات العامـة :در اسـة ميدانيـة

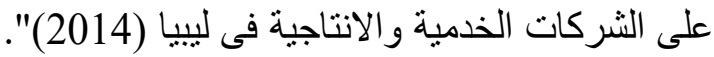

(4) الوسائل الاتصالية المستخدمة فى ممارسة العلاقات العامة ومنها:25

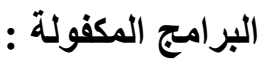

"تقييم البرامج المكفولة فى التليفزيون المصرى (2000)".

مطبوعات العلاقات العامة بشكل عام :

"مطبو عات العلاقات العامة الاستخدامات والاشباعات :در اسـة ميدانية على الجمهور

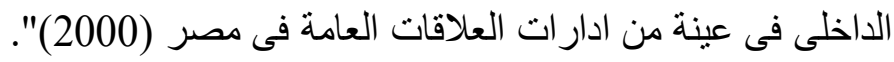

البيانات الصحفية:

"اســتخدامات البيانـات الاخبارية|لصــفية فـى عمـل العلاقـات العامـة فـى مصـر

."(2004) 
بحوث العلاقات العامة والاعلان فى مصر :الواقع واتجاهات المستقبل

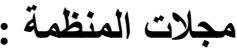

"اسـتخدام اعضــاء النقابـات المهنيـة للمجـلات النقابيـة و الاشـبـاعات المتحققـة منهــا

."(2004)

"تقييم مطبو عات العلاقات العامـة مـع التطبيق على مجلة المهندس الزر اعى الاردنية

."(2007)

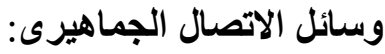

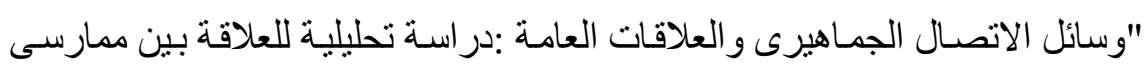

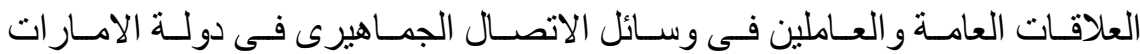

."(2005)

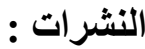

"العمليات الادر اكية لمعلومات النشرات الصحية لدى الثباب الجامعى (2005)"

رعاية الانشطة والاحداث الخاصة:

"العلاقة بين رعايـة المنظمات للانشطة والاحداث الخاصـة وبين اتجاهـات الجمهور

نحو ها (2006)".

"تـأثنير الاحـداث الخاصـة للعلاقـات العامـة على اتجاهـات الجمهـور نحـو المنظمـات العاملة فى مصر (2012)".

"دور ر عايـة الثــركات للاحــداث الرياضـية فـى تـــــيم قيمـة العلامــة التجاريــة ."(2015)

26: ممارسات العلاقات العامة على المستوى الدولى (5) ماتى

فى الشركات متعددة الجنسية:

"العلاقـات العامـة الدوليـة للخطـوط الجويـة السـعودية :در اسـة ميدانيـة على القـائمين بالاتصال و المسافرين (1990)".

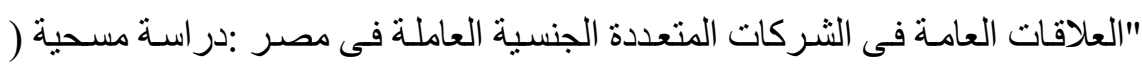
"(2002

"استر اتيجيات الاتصال فى العلاقات العامـة الدولية :در اسـة على المو اقع الاليكترونيـة 
بحوث العلاقات العامة والاعلان فى مصر :الواقع واتجاهات المستقبل

للشركات الامريكية الموجهة للجمهور المصرى (2012)".

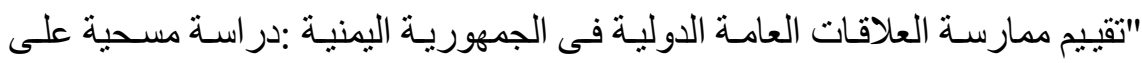

عينة من الثركات الدولية (2013)".

"ممارســة العلاقـات العامـة فـى الثــركات الدوليـة العاملـة فـى ليبيا:در اســة ميدانيـة

."(2014)

و من خلال المكاتب الاعلامية المصرية بالخارج:

"الوظيفة الاتصالية الدولية للمكاتب الاعلامية المصرية بالخارج (1992)".

27: وظائف او مراحل عملية العلاقات العامة

تناولت الدر اسـات على وجـه الخصوص مرحلة التقبيم فـى اطـار عملية العلاقات العامـة

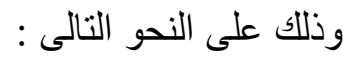
"تقويم فاعلية اداء العاملين فى مجال العلاقات العامة (1998)".

"تصـور مقترح لقياس اداء اجهزة العلاقات العامـة فى ضو ء معايير الجودة الثـاملة

"العو امل المؤثرة على تقويم بر امج العلاقات العامة فى مصر (2015)".

28: (7)

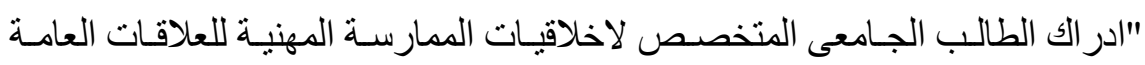

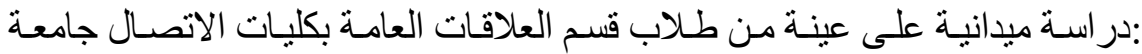
الثنارقة (2015)".

"اتجاهــات طـــلاب العلاقــات العامــة نحــــو الدر اســـة الأكاديميــة للأخلاقيــات المهنية(2016)".

(8) (8) (امج العلاقات العامة

29: 1- اتصالات ادارة القضايا والازمات

• لدرة الاراسات التى تتاولت اتصالات ادارة القضايا بشكل عام ومنها:

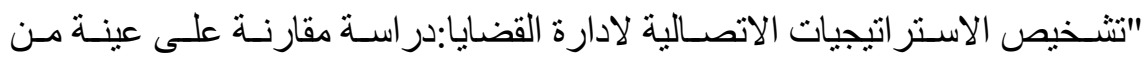

شركات قطاع الاعمال العام والثركات الاستثمارية العاملة فى مصر (2009)". 
بحوث العلاقات العامة والاعلان فى مصر :الواقع واتجاهات المستقبل

او احد الياتها ممثلا فى الرصد البيئى:

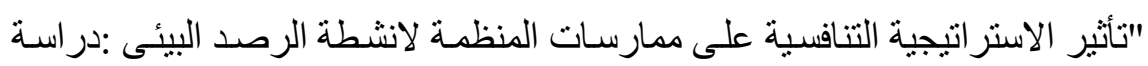

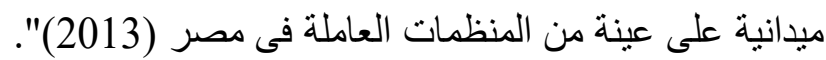
" اما اتصالات ادارة الازمات فتم تناولها من منظور عام فى الدراسات التالية : " تقييم كفاءة الاتصالات فى ادارة الازمة :دراسة حالة (1999)".

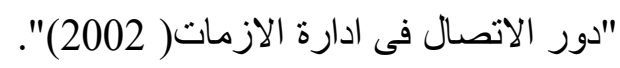
"دراسة تتبعية لتطور دراسات اتصالات الازمة محليا وعالميا (2015)". ثم بالتطبيق على قطاعات بعينها مثل :

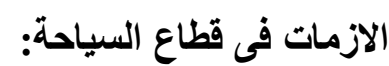

"دور العلاقات العامـة فى ادارة الازمـات :دراسـة تطبيقيـة على قطـاع السياحة فىى

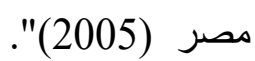

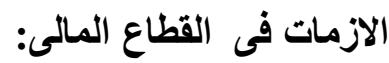

"دور العلاقـات العامــة فـى ادارة الازمــات الاقتصــادية :دراســة حالــة ســوق الــال

$$
\text { الازمات فى القضاء: (2012)". }
$$

"ادارة اتصالات الازمة بنادى قضاة مصر: دراسة حالة (2014)".

القوات المسلحة المصرية :

"المعالجة الاتصالية للأزمات: دراسة حالة على القوات المسلحة المصرية فى الفترة

$$
\text { من 2011/2/11الى 2012/8/12(2015)" }
$$

$$
\text { قطاع شركات الطيران: }
$$

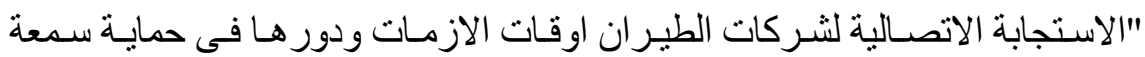
علاماتها التجارية :در اسة حالة على ازمات عربية وعالثية الألية (2016)". • اتجهت الدراسات بعد ذلك لتتاول دور وسائل الاعلام فى الكوارث الطبيعية: 
بحوث العلاقات العامة والاعلان فى مصر :الواقع واتجاهات المستقبل

"دور وسائل الاعلام فى ادارة الكوارث الطبيعية :در اسـة مقارنـة بين وسـائل الاعلام

التقليدية و الحديثة فى نثكيل معارف الثباب عن كارثة سيول جدة 2011 (2012)".

ودور وسائل الاعلام فى الازمات :

"مدى اعتماد الصفوة المصرية على التليفزيون فى وقت الازمات(1998)".

" مدى اعتماد الجمهور على وسـائل الاعلام المصرية اثناء الازمات :دراسـة ميدانية على طلاب الجامعات (2000)".

"اعتمـاد الجمهور المصرى على وسـائل الاعـلام لاكتسـاب المعلومـات عن انفلونز ا الطيور (2007)".

"مصــاقية وســائل الاعـلام المصــرية الحكوميــة و الخاصــة اثتــاء الازمــات :در اســة

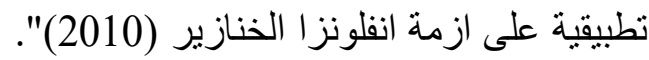

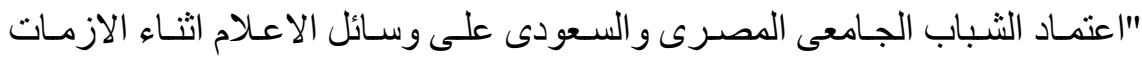

:العملية العسكرية على اليمن (عاصفة الحزم نموذجا ) (2015)".

او احد وسائل الاعلام ومنها :

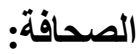

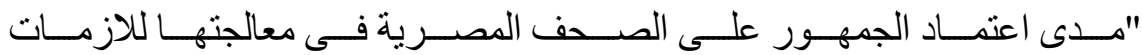

الطارئة:در اسة حالة على حادث سقوط الطائرة المصرية (2001)".

"الخطاب الصحفى فى الازمـات الاقتصـادية :در اسـة حالـة على ازمة رغيف الخبز

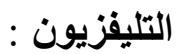

"مدى اعتماد الصفوة المصرية على التليفزيون فى وقت الازمات :در اسـة حالة على العى

حادث الاقصر الار هابى (1998)".

"اعتماد المشاهدين على القنو ات الفضائية خلال الازمات (2006)" .

"اعتماد الجمهور على التليفزيون المصرى اثثـاء الازمـات بالتطبيق على حادث شرم

$$
\text { الثيخ (2005)". }
$$

"اعنماد الجمهور العربى على القنوات الفضـائية الاجنبية الموجهة باللغنة العربية فى 
بحوث العلاقات العامة والاعلان فى مصر :الواقع واتجاهات المستقبل

اوقات الازمات بالتطبيق على ازمة العدوان الاسر ائبلى على غزة (2009)".

"معالجـة التليفزيـون و الصـحف للازمـات فـى المجتمـع المصـرى و علاقتهـا بتشـكيل الاحساس بالخطر الجمعى (2011)".

"مصــاقية القـــوات التليفزيونيـة الاخباريـة خـلال الازمــات: در اســة حالـة للتغطيـة الاعلامية لثورة 25 يناير (2012)".

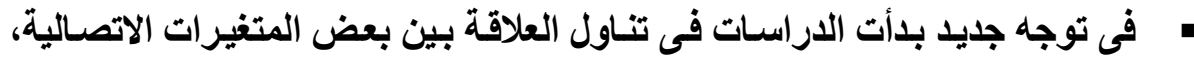

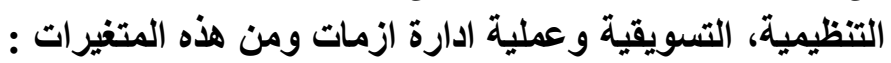
النية الشرائية :

"العو امـل المؤثرة على كيفيـة ادر اكل المسـتهلكين لازمـة المنتج وردود افعـالهم نحـوه :در اسة حالة الثركة المصرية العالمية للتجارة و التوكيلات (2012) ".

الثقافة التظظيمية:

"تأثنير التقافـة التنظيميـة على كفـاءة ادارة اتصـالات الازمـات العماليـة :در اسـة حالـة

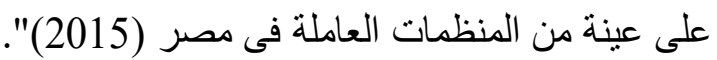

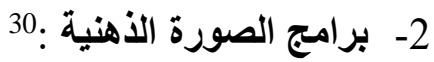

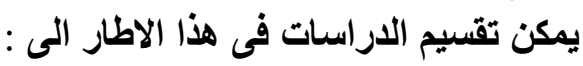
دراسات تتناول الصورة الأهنية للاول والمدن:

"دور الاعلام فى تكوين الصورة الذهنية للعـالم الثالث لدى الثباب المصرى :در اسـة تحليلية ميدانية (1993)"

"دور الاتصال فى تكوين الصورة الذهنية لدى الثعب المصرى (1995)" "صورة الو لايـات المتحدة الامريكية لدى الجمهور المصرى :دراسـة على عينة من سكان محافظة القاهرة الكبرى (2002)".

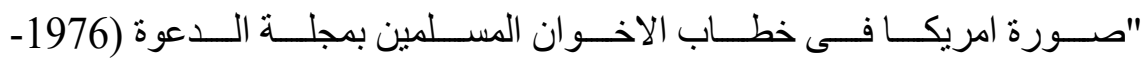
."(2004)(1981

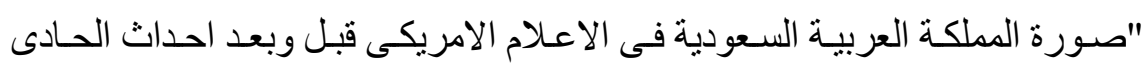
عشر من سبتمبر :در اسة تحليلية على عينة من الصحف الامريكية (2006)".

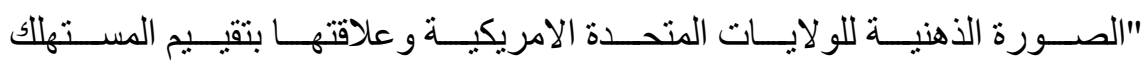
لمنتجاتها(2007)" 
بحوث العلاقات العامة والاعلان فى مصر :الواقع واتجاهات المستقبل

"دور وسائل الاعلام فى تكوين الصورة الذهنية عن الصعيد لدى الثباب (2007)". "الدور الاتصالى للابلوماسية السعودية فى تحسين الصورة الذهنية (2011)". دور وسـائل الاتصـال فى تثـكيل الصـورة الذهنيـة لافغانستان لدى الثنباب المصـرى :در اسة تحليلية ميدانية (2013)".

"صـورة المملكـة العربيـة السـودية في وسـائل الاعـلام الدوليـة بعـد احـداث الربيـع

$$
\text { العربى (2015)". }
$$

دراسات تتناول الصورة الذهنية للمهن:

" الصورة الذهنية لمهنة العلاقات العامة لدى ممارسيها و علاقتها بمستوى ادائهم لها

"العو امـل المؤثرة على تكـوين الصـورة الذهنيـة لممارسـى العلاقـات العامـة :در اســة ميدانية على عينة من المنشأت السياحية بمدينتى الاقصر و الغردقة (2007)". دراسات تتناول الصورة الاهنية للمؤسسات العربية والدولية : "صورة مجلس الامة لدى الثعب الكويتى (2005)".

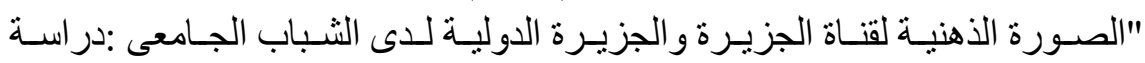

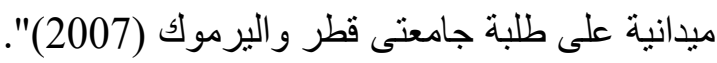
"العو امل المؤثرة فى بناء صورة المجالس التئية التشريعية لدى الجمهور اليمنى (2007)" (2008)".

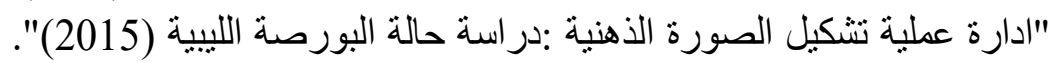

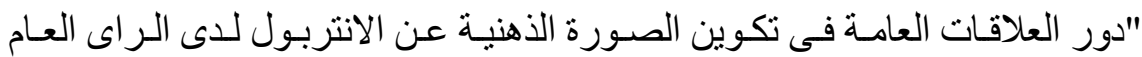
المصرى :در اسة حالة على الانتربول المصرى (2015)".

دراسات تتناول الصورة الذهنية للاجهزة الحكومية والمنظمات الاستثمارية المصرية : "دور العلاقات العامـة فـى تشكيل الصـورة الذهنية للمؤسسـات الحكومية مـن منظور

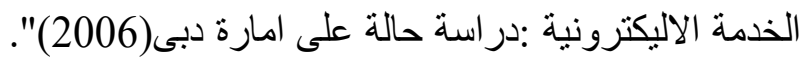
"صورة جهاز الثرطة عقب ثورة يناير 2011 و اليات تحسينها :در اسـة ميدانية على عينة من الجماهير ورجال الثرطة (2015)". "دور امتداد العلاقة التجارية فى تكوين الصور الذهنية للثـركات لدى المستهلكين فى لـى السوق المصرى (2015)". 
بحوث العلاقات العامة والاعلان فى مصر :الواقع واتجاهات المستقبل

دراسات تتناول الصورة الذهنية للمنتج :

"تأثير متغير بلد المنشأعلى الصورة الذهنية للمنتج :دراسة تجريبية فى اطار نظرية تمثيل المعلومات (2013)".

دراسات تتناول الصورة الذهنية للافراد :

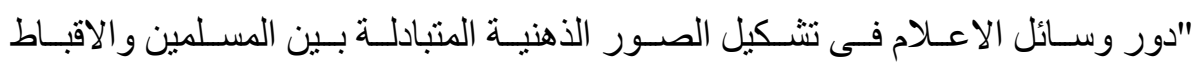
." (2009)

"دور وسائل الاعلام فى تثكيل الصورة الذهنية للحكام العرب لاى الثباب اليمنى بعد تورات الربيع العربى (2013)".

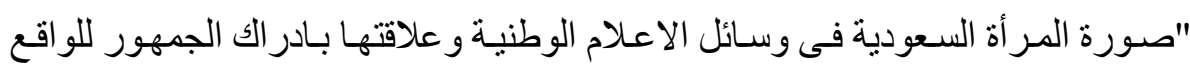

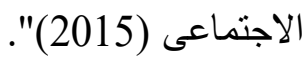

"الصورة الذهنية لاى الطفل عن ذوى الاحتياجات الخاصة كما تعكسها وسائل الاعلام (2015)".

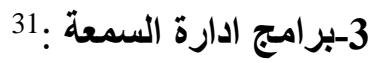

تناولت الدراسات فى هذا الاطار العلاقة بين اتصالات ادارة السمعة وبعض المتغيرات ومنها:

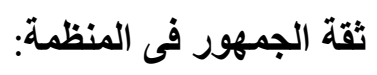

"ادارة سمعة المنظمات المصرية وعلاقتها بثقة الجمهور نحوها (2013) ".

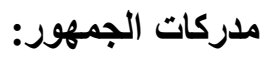

"مدركات الجمهور المصرى لاتصـالات ادارة سمعة الجامعـات المصـرية الخاصــة

(2015)

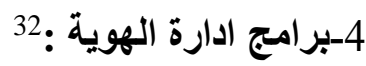

و انحصرت الدراسات فى هذا المجال فى دراسة واحدة هى :

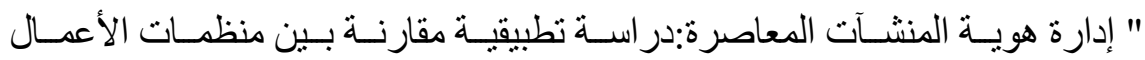

$$
\text { المصرية و الدولية في مصر (2010)" الدئن }
$$


بحوث العلاقات العامة والاعلان فى مصر :الواقع واتجاهات المستقبل

53: برامج المسئولية الاجتماعية

تقسم الدراسات فى هذا المجال الى دراسات عامة :

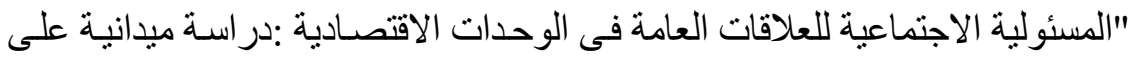

عينة من شركات القطاعين العام و الخاص (1990)".

و حديثا بدأت فى الربط بين اتصالات المسئولية الاجتماعية و بعض المتغيرات :

سمعة المنظمة : سمة

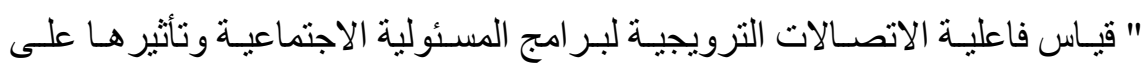

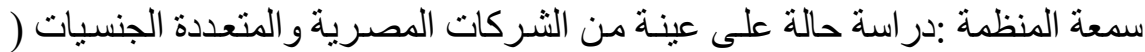

. "(2014

"قياس فاعلية الاتصـالات الداخلية للمسئولية الاجتماعية فى بنـاء سمعة المنظمـة لدى

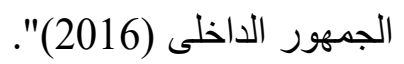

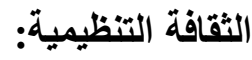

" تأثير الثقافـة التنظيميـة على اتصـالات المسئولية الاجتماعيـة للمنظمـات العاملـة فىى

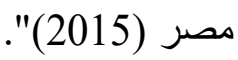

\section{وعى واتجاهات الجمهور :}

" تأثير إتصـالات المسئولية الإجتماعيـة للشركات على وعى و اتجاهـات العملاء نحو الأنشطة التسويقية للمسئولية الاجنماعية (2016)".

بل واتجهت الدراسات حديثا نحو منحى جديد تمثل فى :

"تقييم جودة الاداء الاجتماعى للثركات العاملة فى مصر (2016)".

34: 6 الاتصالات المؤسسية

الاراسات فى هذا المجال محدودة جدا ومنها :

"الرضا الوظيفى لاى اعضاء هيئة التدريس الاكاديمى بمجال الاتصال (2016)"

وبدأت حديثا تتجه نحو الموضوعات المتخصصة فى هذا المجال ومنها :

اتصالات ادارة التغيير: 
بحوث العلاقات العامة والاعلان فى مصر :الواقع واتجاهات المستقبل

"دور الاتصـال فـى عمليـة التغييـر فـى المنظمـات :در اسـة على عينـة مـن المنظمـات

$$
\text { الانتاجية والخدمية فى مصر (2006)". }
$$

"دور الاتصـال فـى ادارة التغيير و الصـر اع فـى المنظمـات الحكوميـة :در اسـة تطبيقيـة على وزارة التعليم العالى (2011)" الأفئي

اتصالات ادارة علاقات المنظمات بمجموعات المصالح :

"كفاءة ادارة علاقات المنظمة مع مجمو عات المصالح (2011)".

اتصالات تنمية المنظمات :

" تقييم ممارسات اتصالات تنمية المنظمات :در اسـة مسحية على عينـة من المنظمـات العاملة فى مصر (2012)".

اتصالات ادارة الصراع التنظيمى: "دور وسائل الاعلام كأداة فى الصر اع (1997)".

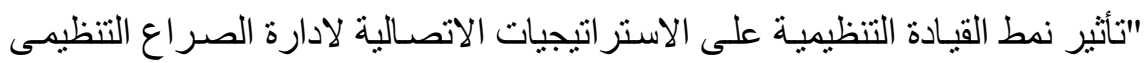
:در اسة ميدانبة على عينة من المنظمات العاملة فى مصر (2013)".

التعليق على العرض السابق من حيث :

الفترات الزمنيـة التى تركز فيهـا الانتـاج العلمى فـى مجـال العلاقـات العامـة وبرامجهـا

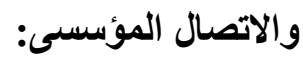

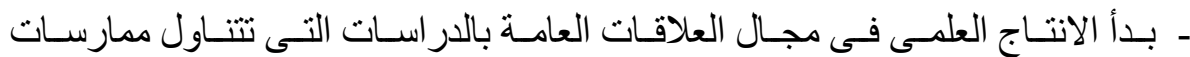

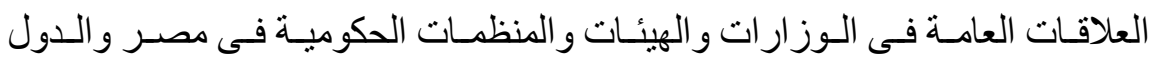

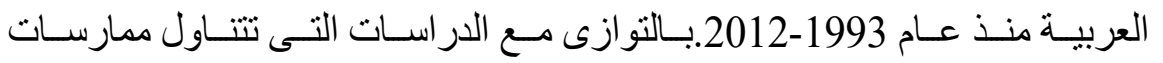

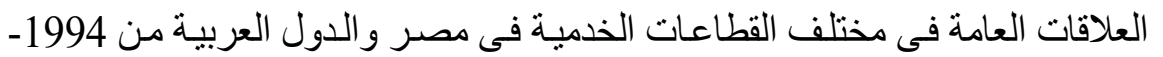

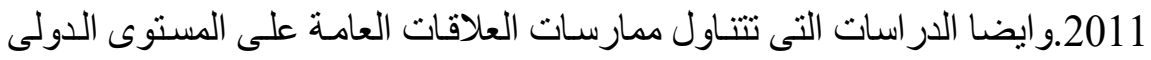

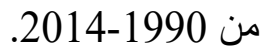

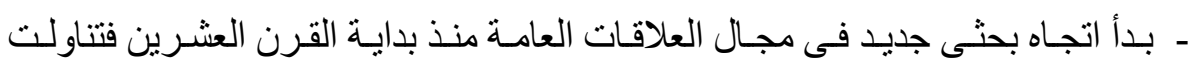

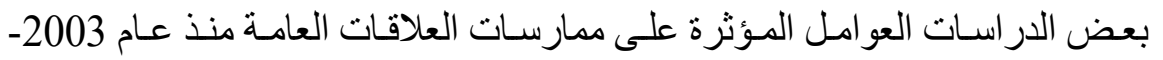

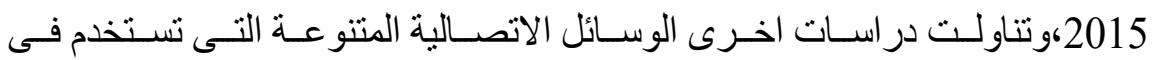
ممارسة العلاقات العامة من عام درات 2000-2015. 


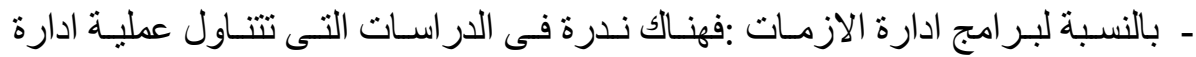

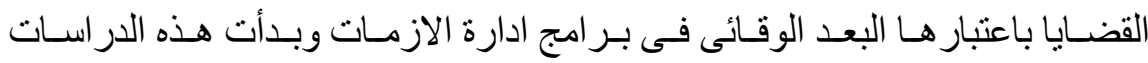

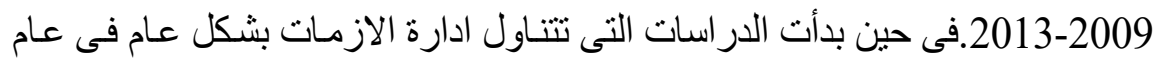

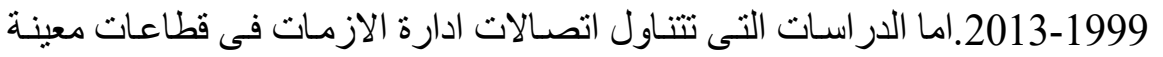

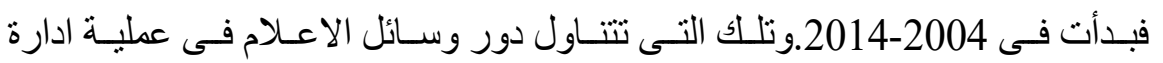

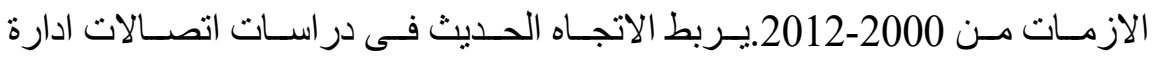

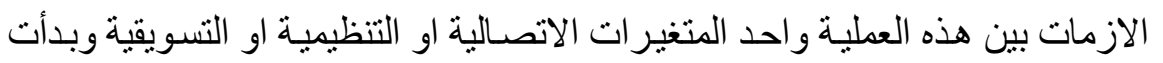
فى عام 2012ومستمرة.

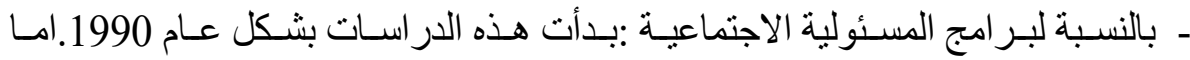

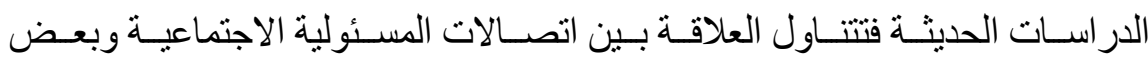
المتغير ات التنظيمية والاتصالية منذ عام 2014ومستمرة.

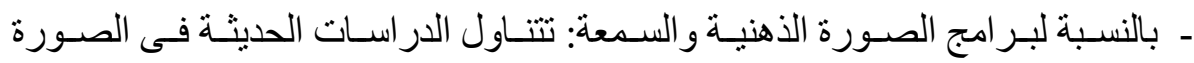

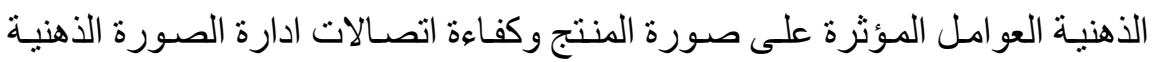

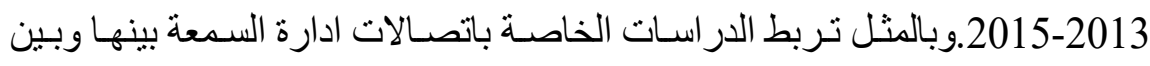

متغير ات اتصالية وتنظيمية 2013-2015.

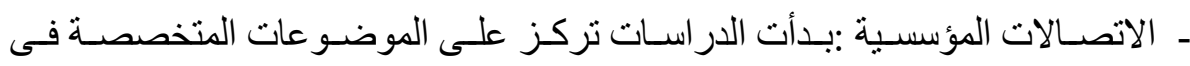

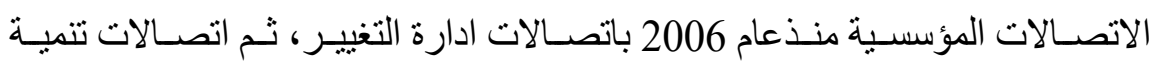
المنظمات 2012،وحديثا اتصالات ادارة الصر اع التنظيمى التصام 2013.

من حيث نوع الار اسات ومنهجها:

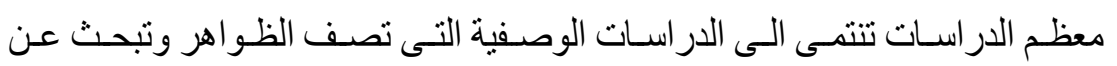

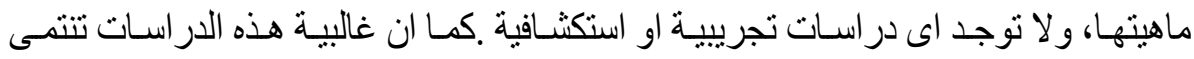
الى البحوث الكمية التى تقدم مدلو لات رقمية دون الاهتمـام بالبحوث الكيفية. فاعنمد غالبيتها

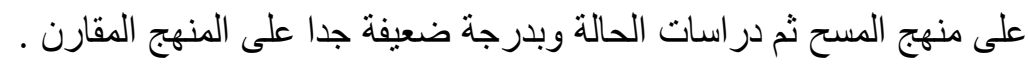
من حيث ادوات جمع البيانات ومجتمع وعينة الدراسة :

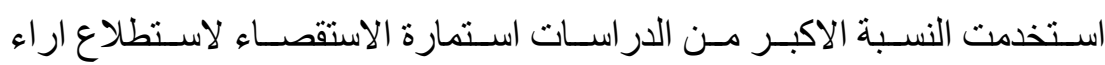

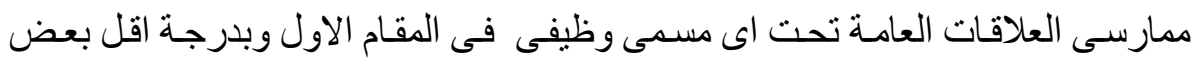

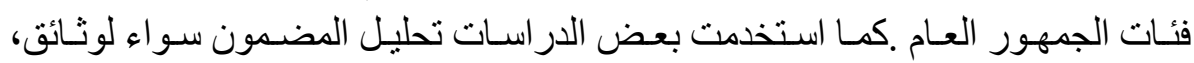

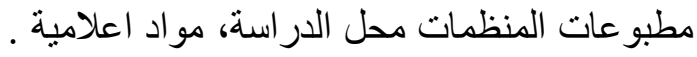


بحوث العلاقات العامة والاعلان فى مصر :الواقع واتجاهات المستقبل

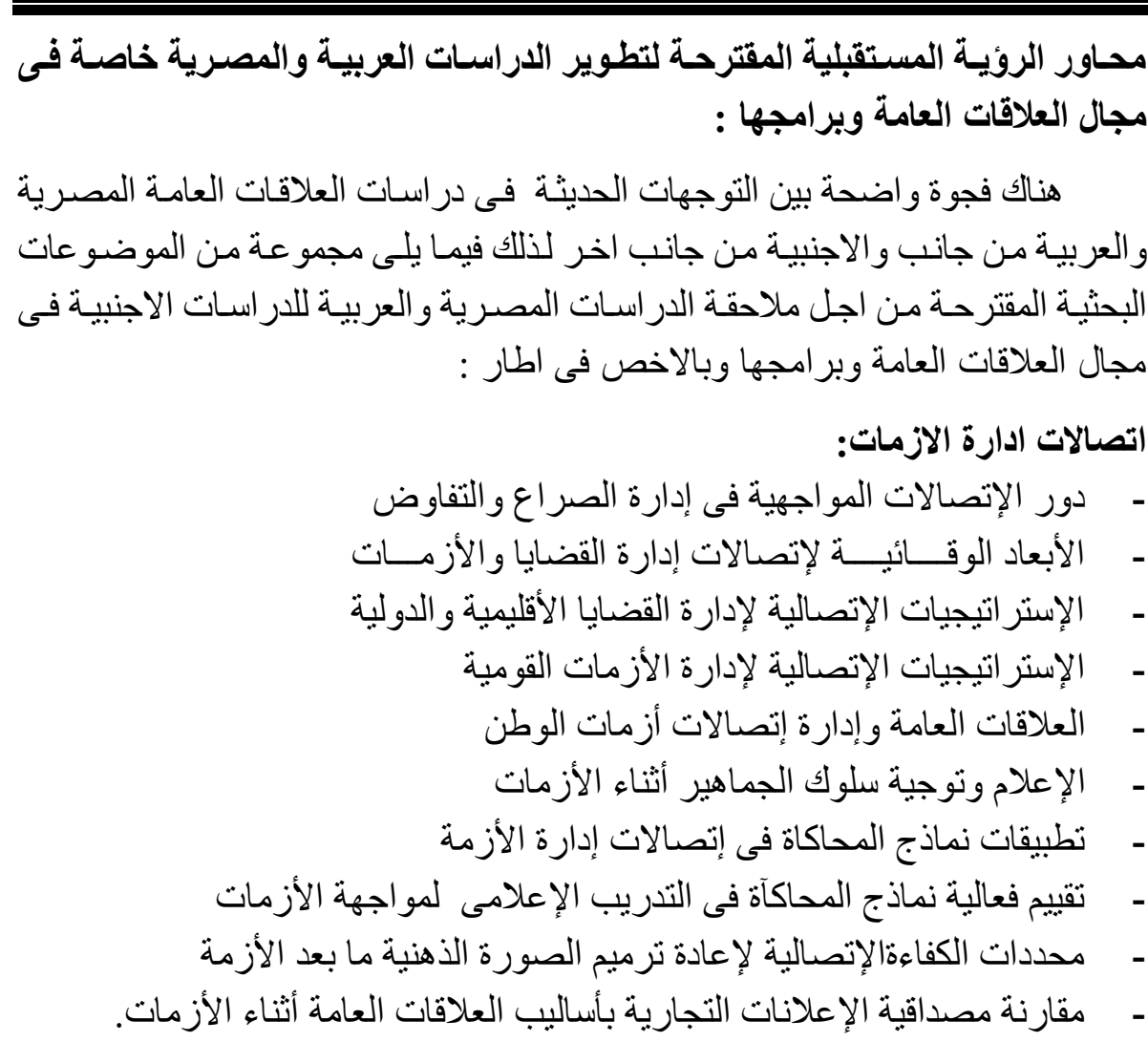

الاتصالات المؤسسية : الأسية

- الآليات الإتصالية لنشر الثقافة التنظيمية الحاكمة لعمل المنظمات المصرية

$$
\text { و علاقتها بالأداء المؤسسى الرشيد و الإنة الحوكمة. }
$$

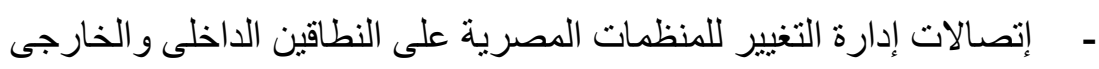

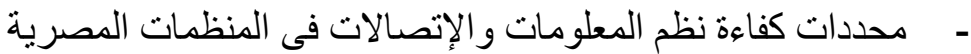

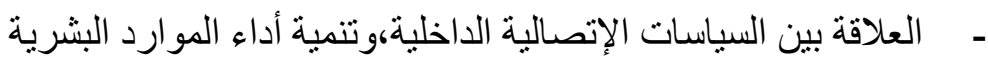

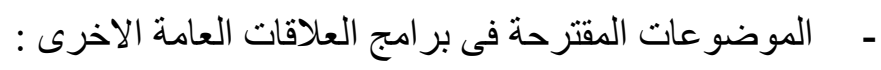

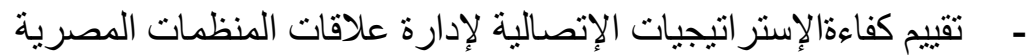

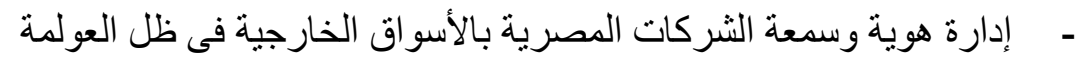

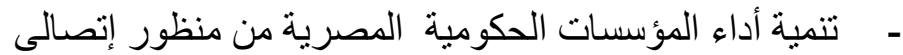

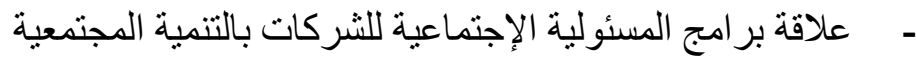

- 
بحوث العلاقات العامة والاعلان فى مصر :الواقع واتجاهات المستقبل

35: الاراسات التى اجريت فى مجال الاعلام التربوى من اوائل الاراسات فى هذا المجال :

"قسم الاعلام بجامعة قطر والاتجاهـات الحديثة للتعليم الاعلامسى :در اسـة استطلاعية

ثم توالت الاراسات بعد ذللك بفترة ليست بقصيرة ومنها :

"دور وسـائل الاعلام التربوى فى تحقيق حاجـات الاطفال ذوى الاحتياجـات الخاصـة

"الرضـا الوظيفى لـدى اخصـائى الاعـلام التربـوى وعلاقتــهـ بـالاداء المهنى :در اســة ميدانية (2011)".

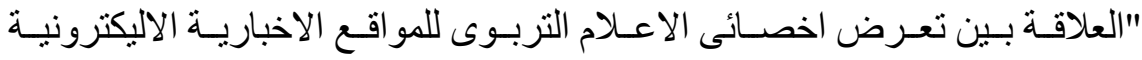
ومستوى المعرفة بالاستر اتيجية الوطنية لمكافحة الفساد فى مصر لونى (2014)". "دور بـر امج التربيـة الاعلاميـة فى تنميـة مهار ات استخدام الطـلاب لوسـائل الاعـلام

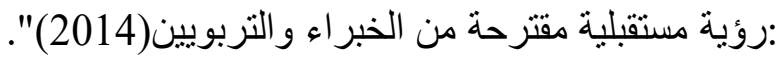

"اتجاهـات اخصـائى الاعـلام التربـوى نحــو المهنـة وعلاقتهـا بمسـتوى الدافعيـة نحـو تطوير قدر اته المهنية (2015)".

"تقيـم الخبـر اء للمعـايير الاكاديميـة القياسـية و لاداء خريجـى كليـات و اقسـام الاعـلام و الاعلام التربوى بالجامعات المصرية (2015)".

"اتجاهـات طـلاب الاعـلام التربوى نحو مستقبلهم المهنى و علاقتها بمستوى الرضــا. التعليمى لايهم (2015)".

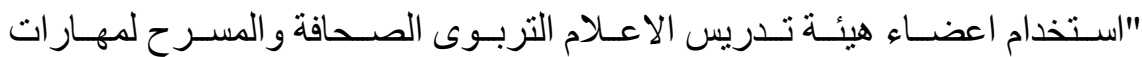

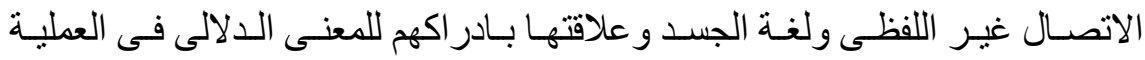
التدريسية (2015)".

الاراسات التى اجريت فى مجال الاعلام الجديد وتوظيفه فى المجالات السابقة : يمكن تصنيف الموضـوعات التـى تناولتهـا الاراسـات التـى اجريـت فـى مجـال الاعـلام

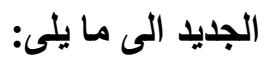


بحوث العلاقات العامة والاعلان فى مصر :الواقع واتجاهات المستقبل

(1) فـى البدايـة عقدت الدر اسـات مقارنـة عامـة بين وسـائل الاتصـال التقليديـة والحديثة

$$
\text { 36: ومنها }
$$

"الاعلام الجديد والاعـلام الكلاسيكى بين الاتصـال والانفصـال :التليفزيون العمومى

$$
\text { نموذجا (2009)" }
$$

ثم عقدت بعض الدراسات مقارنة بين الوسائل التقليدية والحديثة من منظور الجمهور

" دور الانترنــت و الر اديـو و التلبفزيــون فـي إمــاد الجمهـور المصـري بالمعلومـات

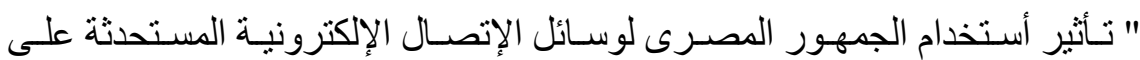

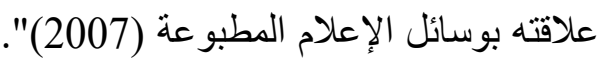

" العلاقـة بين استخدام الجمهور المصـرى للقنـوات الفضـائية والإنترنـت خـلال ثُورة 25 يناير و التأثنيرات المعرفية والوجدانية و السلوكية (2013)".

كمـا عقدات بعض الدراسـات مقارنـة بين معالجـة احـ القضـايا عبر الوسـائل التقليديـة

$$
\text { والحديثة: : }
$$

"در اســة مقارنــة بـبن صـورة مصـر فـى المضـمون الصـحفى المطبو ع و على شبكة

الانترنت لصحف الدايلي تلجر اف وواشطن بوست وجيروز ايم بوست (2003)".

"اعتمـاد المـر اهقين السـعوديين على وســائل الاعـلام فـى المعرفـة بالقضــايا المحليـة

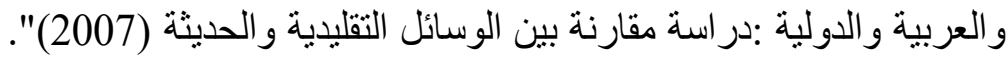

"وسـائل الاعـلام التقليديـة و الجديـدة و المجــال العـام :در اســة تطبيقيـة علـى قضــايا

$$
\text { الحريات (2009)" (") }
$$

"معالجـة قضـايا حقوق الانسـان فى الصـحف وشبكة الانترنت فـى المملكـة العربيـة

$$
\text { السعودية (2010)". }
$$

"اتجاهـات جمهور وســائل الاعـلام فـى البحـرين نحـو المعالجـة الاعلاميـة للقضــايا

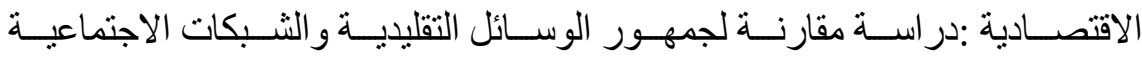

$$
\text { ."(2011) }
$$

" معالجــة وسـائل الاعـلام التقليديـة و الجديــدة لقضــايا الفســاد فـى مصـر : دراســة 
بحوث العلاقات العامة والاعلان فى مصر :الواقع واتجاهات المستقبل

اللمضمون و القائم بالاتصال و الجمهور(2013)".

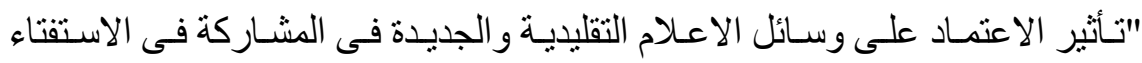

الدستورى 2014:در اسة ميدانية على عينة من مجتمع جنوب الصعيد (2014)".

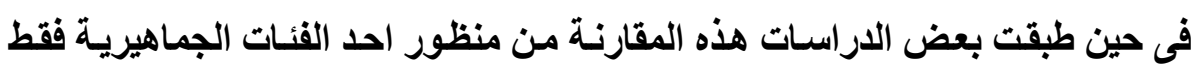

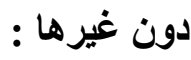

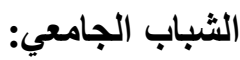

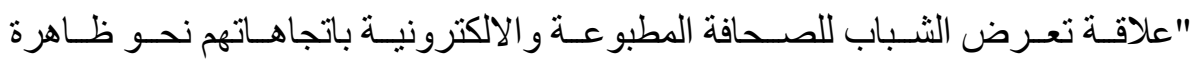
الإر هاب: در اسة تحليلية ميدانية (2006)" .

" دور وسائل الأتصال الحديثة فى تثكيل العلاقات الأجتماعية للثباب الجامعى دراسة الأنة

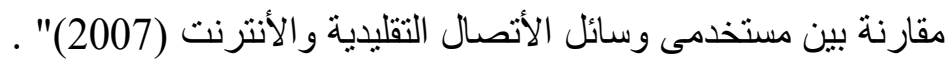

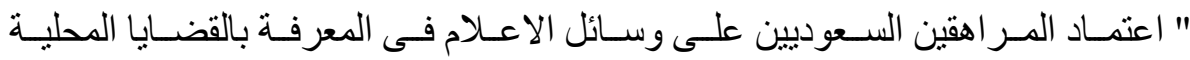
و العربية والدولية :در اسة مقارنة بين الوسائل التقليدية والحديثة (2007) ".

" اعتماد الثباب على وسائل الاعلام التقليدية والحديثة كمصدر لمعارفهم الثقافية ( 2012)" ل

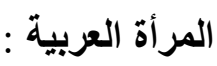

" العلاقة بين تعرض المـر أة العربيـة للمـادة الإخباريـة في وسـائل الاتصـال الحيثئة و التقليدية ومستوى مشاركتها السياسية (2011)".

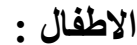

"ناثير عولمة الاعلام فى مجال التربية البدنية والرياضبة على استخدام الطفل الكمى و النوعى لوسائل الاعلام وتكنولوجيا الاتصال الحديثة (2012)".

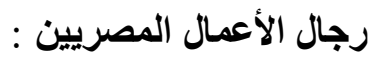

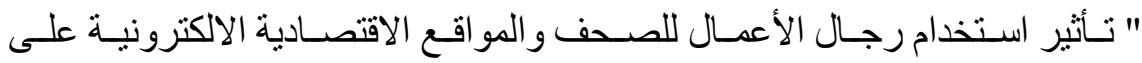

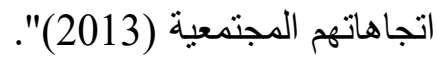

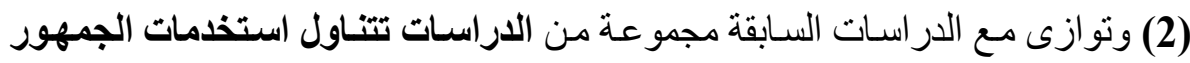

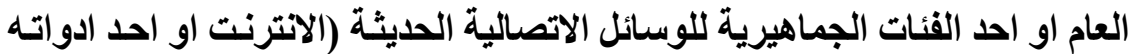
37: الاتصالية و التليفون المحمول الجمانيان 
بحوث العلاقات العامة والاعلان فى مصر :الواقع واتجاهات المستقبل

تنقسم الاراسات فى هذا الاطار الى قسمين :

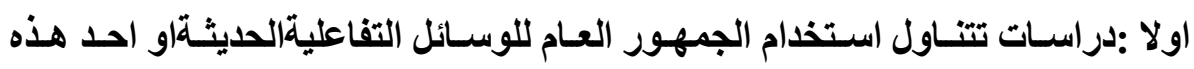

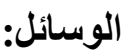

" استخدامات الجمهور المصري للصحف اليومية الإلكترونية على شبكة الانترنت: در اسة تحليلية وميدانية (2004)".

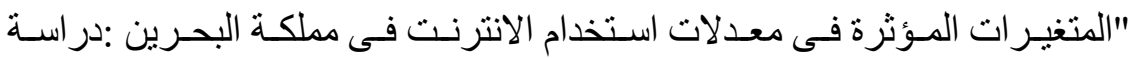

ميدانية فى اطار نموذج الاستخدامات و الاشباعات(2006) ".

"ادوار مستخدمى المو اقع الاليكترونيـة فـى صناعة المضـامين الاعلامية :در اسـة فىى

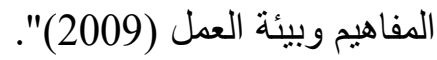

"ادر الك الجمهور و القائم بالاتصـال للخدمات الاعلاميـة المقدمة عبر الهاتف المحمول

"العو امل المؤثرة على استخدام الجمهور لالعاب الانترنت فى اطلار نظريـة الاندماج

."(2013)

"تبنـى شـبكات التو اصـل الاجتمـاعى فـى مصـر :در اسـة مقارنـة بـين المتبنـين وغير المنبنين (2015)".

ثانيا: دراسات تتناول استخدام احد الفئات الجماهيرية للوسائل التفاعلية الحديثة:

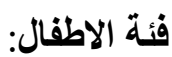

" دو افع استخدامات الاطفال لثبكة الانترنت و الاشباعات المتحققة (2002)" . "توظيـف التقنيـات التكنولوجيـهـ الحديثـة فـى الاعـلام الالبكترونسى للطفـل العربـى ."(2011)

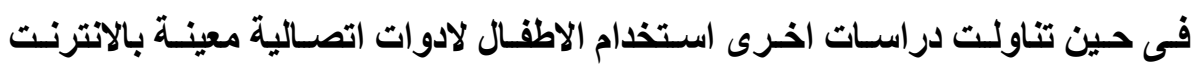
ومنها:

" هل تقدم منتديات الأطفـال علاقـات اجتماعيـة افتر اضية للعلاقـات الحقبقية؛؟ ورقـة

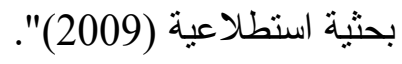

ركزت دراسات اخرى على فئة المراهقين : 
بحوث العلاقات العامة والاعلان فى مصر :الواقع واتجاهات المستقبل

"دو افـع تعـرض تلاميـذ الاعـدادى للمـو اد التعليميـة و الاثر ائيـة مـن شـبكة الانترنــت ." (2008)

"استخدام المر اهقين بالعـالم العربسى للفيس بوك و الاشـباعات المتحققة لديهم: در اسـة ميدانيـة على طـلاب المرحلـة الثانويـة بالعـالم العربـى فـى ضـو و نظريـة الاسـتخدامات

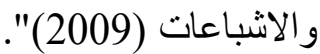

" دو افع استخدام المر اهقين للإعلام الالكترونـي و اشباعاته :در اسـة تطبيقية للأنترنت وغرف الدردشة (2014)".

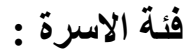

"علاقـة الاسـرة السعودية بالمجتمعـات الافتر اضية خـلال العقد الاول مـن استخدامها للانترنت (2009-1999) (2009)".

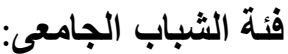

" استخدام الانترنت فى العالم العربـى :در اسـة ميدانية على عينة من الثباب العربى ."(2000)

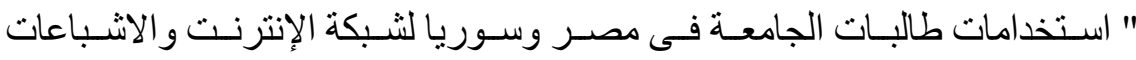

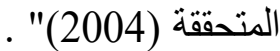

"استخدامات الثباب الكويتى لثبكة الانترنت و الاشباعات التى تحققها (2004)".

"دو افـع تعـرض الثــباب الجـامعى البحرينــى للانترنــت و الاشـــاعات المتحقةــة ."(2004)

" علاقـة تعـرض الثشباب للصـحافة المطبو عـة و الالكترونيـة باتجاهـاتهم نحـو ظـاهرة الإرهاب :دراسة تحليلية ميدانية (2006)" .

" اعتمـاد الثباب الجامعى على المو اقع الاذاعيـة والتليفزيونية الاليكترونية للحصول على المعلومات السياسية (2006)" .

"استخدام الانترنت مقابل وسائل الاعلام التقليدية بين طلاب الجامعات في الامـارات العربية المتحدة (2008)".

"دو افع استخدام الثباب الكويتى للمواقع الاليكترونية عبر الانترنت :در اسـة ميدانية ."(2011) 
بحوث العلاقات العامة والاعلان فى مصر :الواقع واتجاهات المستقبل

"اتجاهات الثباب المصرى نحو شبكات التو اصل الاجتمـاعى على الثبكة العنكبوتية :فى اطار نظرية الثراء الاعلامى (2011)".

"استخدام طلبـة اقسـام العلاقات العامـة بكليات الاتصـال و الاعلام لمصـادر المعلومـات

الاليكترونيـة و اتجاهـاتهم نحو هـا :در اسـة على عينـة مـن جامعـات مصـرية وامارتيـة الاتية

"اســخدام الثـباب الجـامعى الاردنـى للمو اقع الاجتماعيـة على الانترنـت وتأثثير اتهـا :الفيس بوك نموذجا (2011)".

" الاستخدامات و الاشباعات المتحققة من استخدام الشباب فى سلطنة عمـان للهاتف

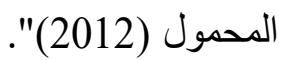

" اعتمـاد الثباب المصـري على المو اقع الإسـلامية العربيـة در اسـة مسحية وكيفيـة (2013 ."(2013

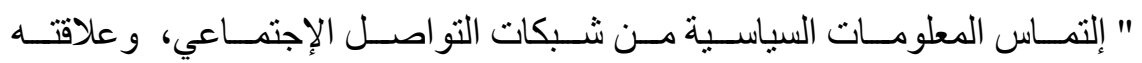
بالإتجاهات التعصبية لاى الثباب المصري(2013)".

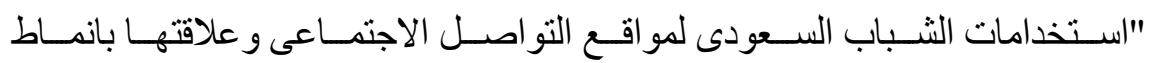
الثخصية (2013)"

"علاقة الثباب المصري بـالمو اقع الالكترونية الاسر ائبلية الناطقة باللغة العربية على

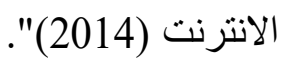

"و اقع تصفح واستخدام المو اقع الاليكترونية من قبل طلبة قسم الصحافة و الاعلام فىى

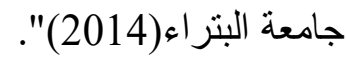

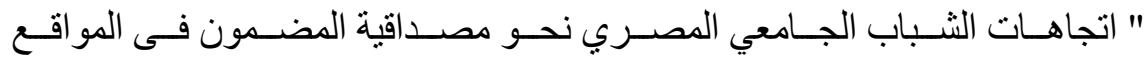

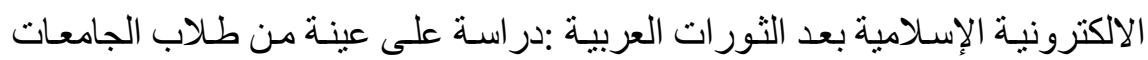
الاقليمية المصرية ( 2015)".

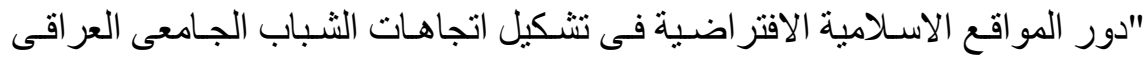
نحو القضايا الدينية المعاصرة :در اسة تحليلية ميدانية (2015)".

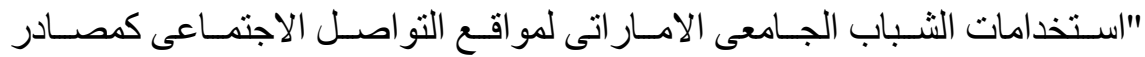
للمعلومات الثقافية (2015)". 
بحوث العلاقات العامة والاعلان فى مصر :الواقع واتجاهات المستقبل

"اعتماد الثباب على المواقع الدينية :دراسة مسحية (2015)".

تناول عدد محدود من الدر اسات فئة المرأة:

"العو امـل المـؤثرة فـى تعامـل الفتـاة العربيـة مـع الانترنت:در اسـة سوسـيو ـاعلاميـة

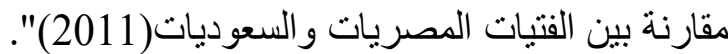

"استخدامات المـر أة المصرية لثبكة الإنترنت و الإشباعات المتحققة لديها بـالتطبيق

على "أحداث ثورة 25 يناير 2011 (2012) ".

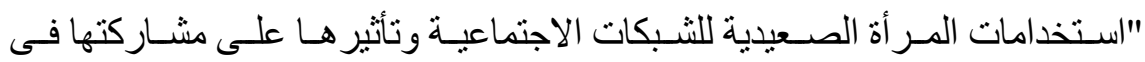

الانتخابات الرئاسية 2012: دراسة ميدانية (2013)".

منظمات المجتمع المدنى :

"وسائل الاعلام الجديدة و المجتمع المدنى :رؤيـة تحليلية نقديـة لاستخدام الانترنت فى لئ

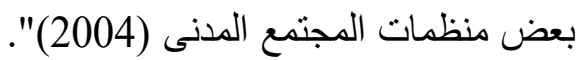

فئة الصفوة متمثلة فى اساتذة الجامعات:

"علاقة الصفوة بالحاسب الالى واستخدام الانترنت (2006)".

"ألتمـاس المعلومـات السياسية على مو اقع التو اصـل الاجتمـاعي و علاقتها بمصداقية الاقية

المضمون لدى دارسي الإعلام التربوى بالجامعات المصرية المعية ( 2014 )".

فى حين ركزت احد الدر اسات على فئة الحجاج والمعتمرين:

"اعتمـاد الحجـاج و المعتمـرين على الوسـائل التكنولوجيـة الحديثة للاتصـال كمصدرر

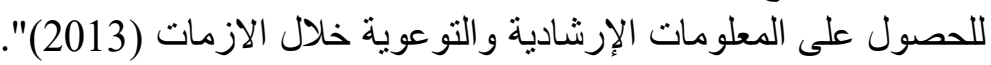

واخير أئة ذوى الاحتياجات الخاصة:

" العلاقة بين تصميم المواقع الاخباريـة ويسر استخدام المكفوفين لها وتفاعلهم معها

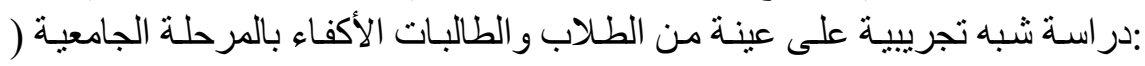

." 2012

"استخدام المكفوفين للإنترنت و علاقته بتلبية احتياجاتهم التعليمية ( 2014)".

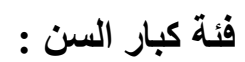

" آثنار الضــف الإدر اكى المعتدل على اسـتخدام كبـار السـن لتكنولوجيـا الاتصــال 
بحوث العلاقات العامة والاعلان فى مصر :الواقع واتجاهات المستقبل

$$
\text { :در اسة كيفية على مستخدمى الإنترنت (2015)". }
$$

"تقييم خبرات المستخدمين من كبار السن لتكنولوجيا الاتصال (2016)".

(2) الدراسـات التى قامت بتوصيف المضـمون الذى يقدم عبر هذه الوسـائل التفاعلية

$$
\text { 38: الحديثة }
$$

"المدونات المصرية على شبكة الانترنت (2008)".

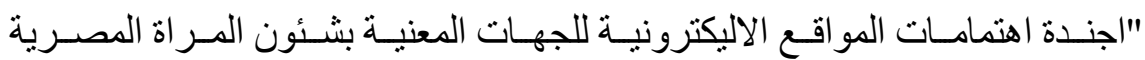

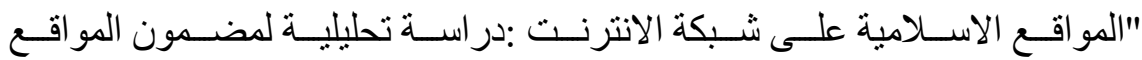

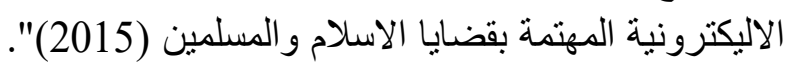

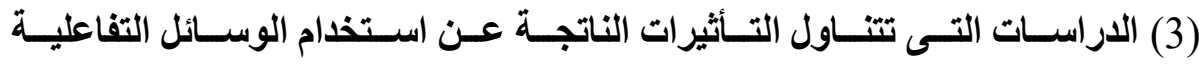
الحديثة(الاتترنت - او احد ادواته الاتصالية ـ والتليفون المحمول )

$$
\text { ومنها دراسات تناولتها بشكل عام : }
$$

"التأثير ات المترتبة على استخدام الثباب الجامعى لموقع الفيس بوك (2011)"

40: ودر اسات تناولت تأثثير ات بعينها يمكن تقسيمها على النحو التالى

اولا: دراسـات تتــاول التأثيرات الاجتماعية والاخلاقيـة الناتجـة عن استخدام الانترنت

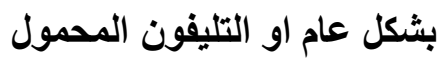

" اثر استخدام تكنولوجيا الاتصال الحديثة على انماط الاتصال الاسرى (2003)" .

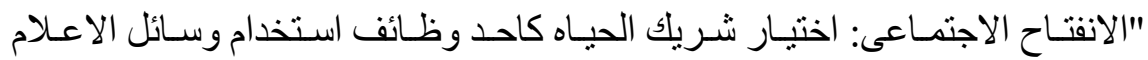

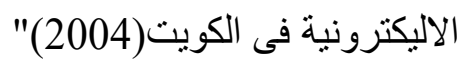

" علاقـة وسـائل الاتصــال الحديثة بـالاغتر اب الاجتمـاعى للشبـاب المصـرى :در اســة

$$
\text { ميدانية (2006)" (2006) }
$$

$$
\text { " دور شبكة الانترنت فى دعم الحوار الاسرى (2007)". }
$$

" نأثير الإنترنت في التفاعل العائلي :قراعة في نوجهات البحوث العلمية ( 2009)".

"تأثنير الإنترنت في علاقات الثباب الاجتماعية والأسرية :دراسـة ميدانية على عينة

$$
\text { من شباب ولاية الخرطوم- السودان ( 2009)" . }
$$


بحوث العلاقات العامة والاعلان فى مصر :الواقع واتجاهات المستقبل

" المخـاطر المتعلقة بالإباحيـة الالكترونيـة علي الثباب المصري وآليـات مكافحتها :در اسة ميدانية علي عينة من الثباب الجامعي ( 2009)" .

"الاتصـال عبـر الانترنـت وتـأثيره فـى اكتســاب المهـار ات الاجتماعيـة لـدى طـلاب الجامعات :در اسة ميدانية (2011)".

" استخدام الجمهور المصري للتليفون المحمول وعلافته بالتفاعل الاجتماعي( 2013)".

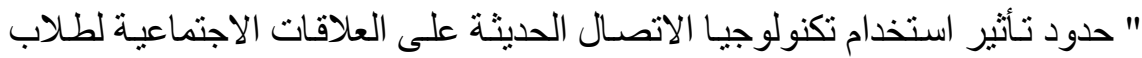
الجامعات فى اليمن :در اسة مقارنة على الانترنت و الهاتف المحمول (2013)". "مشكلات الاسرة المصرية الناجمة عن الاستخدام السىء للانترنت من وجهة نظر الو الدين :در اسة ميدانية (2014)". "اسـتخدام طالبـات الجامعـات المصـرية والسـعودية لوسـائل الاعـلام الجديـد و علاقتــهـ

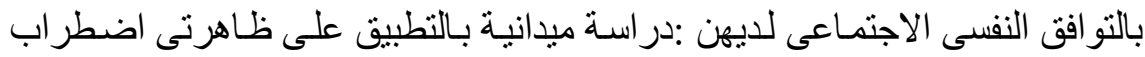

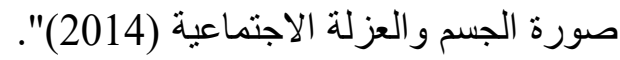

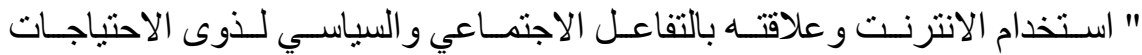

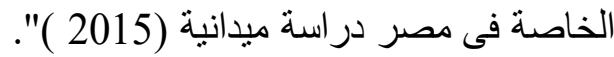

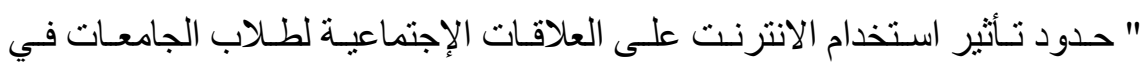
اليمن(2016)".

"استخدام الهاتف المحمول وتأثيره على العلاقات الاجتماعيـة لطلاب الجامعات فى اليمن (2016)".

"دور الاعـلام الجديد في تغيير المنظومـة القيمية لدى الثـباب :در اسـة تطبيقيـة على

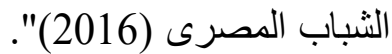

كمساركزت بعض الاراسـات على التـأثير ات الاجتماعيـة لشبكات التواصل الاجتمـاعى

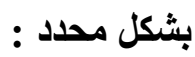

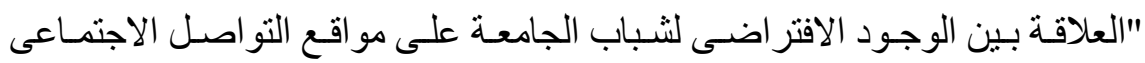

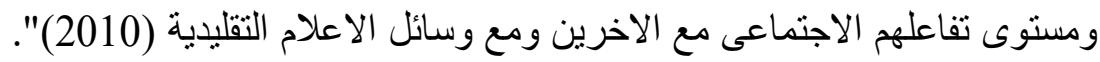

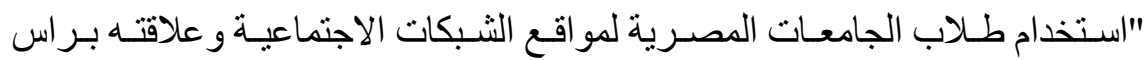
المال الاجتماعى بالتطبيق على موقع فيس بوك (2011)". 
بحوث العلاقات العامة والاعلان فى مصر :الواقع واتجاهات المستقبل

"الاتصــال التفـاعلى مـن خـلال مو اقع الثـبكات الاجتماعيـة و علاقتهـا بـر اس المــال

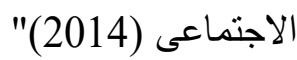

" تأثنير استخدام تكنولوجيا شبكة التو اصل الاجتماعي عبر الانترنت على العلاقات الاجتماعية للأسرة المصرية (2015)".

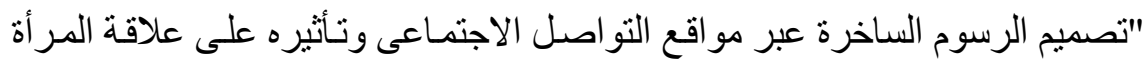
بالرجل :در اسة تطبيقية على صفحات الفيس بوك الك (2015)".

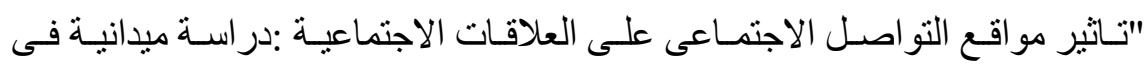
ضوء نظريتى الحتمية التكنولوجية والقيمية (2016)".

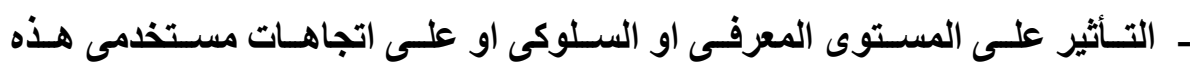
الوسائل:

" تأثنير مضـمون الرسـالة الإعلاميـة علي اكتسـاب المعرفـة في الوسـائل الاكترونيـة

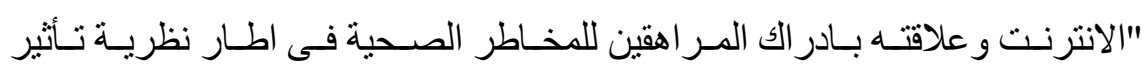

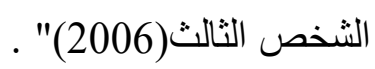

"دور اسـاليب الاتصـال الاليكترونسى عبـر الانترنــت فـى دعـم الانشــة الاكاديميـة

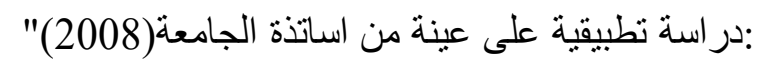

"ادر اك الجمهور و القائم بالاتصال للخدمة الاعلامية المقدمة عبر الهاتق المحمول (2009)". "اتجاهات الثباب المصرى نحو شبكات التو اصل الاجنماعى على الثبكة العنكبوتية :فى اطار نظرية الثراء الاعلامى (2011)".

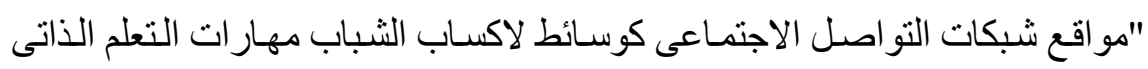
وسلوك المشاركة المدنية (2011)".

" تـأثنير الثخصـيات الكارنونبـة المحوريـة فـى مواقع الاطفـال الالكترونيـة على قيم واتجاهات الطفل المصري (2012)".

"العلاقة بين استخدام الجمهور المصـرى للقنوات الفضـائية والانترنت خـاتلال ثورة

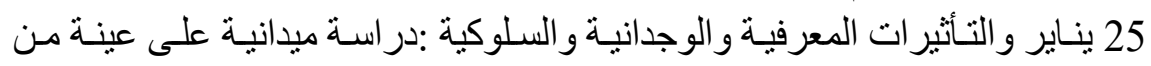

الجمهور المصرى (2012)". 
بحوث العلاقات العامة والاعلان فى مصر :الواقع واتجاهات المستقبل

" أثز الفيس بوك على مستويات الأداء الدراسي للشباب الجامعي(2014)".

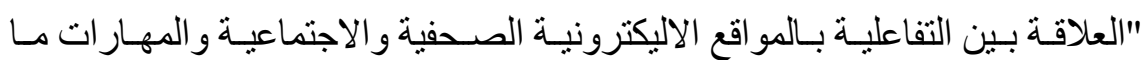

ور اء المعرفية لاى مستخدمى تللك المو اقع (2014)".

"دور الاعلام الجديد فى تتمية الوعى السياسى لدى الثباب الجامعى (2015)".

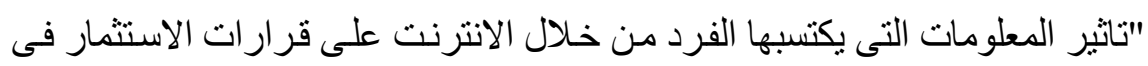

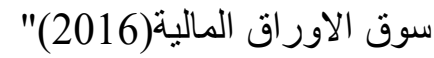

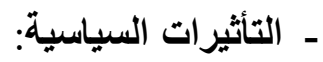

"دور التليفزيون والانترنت فى التنشئة السياسية الدولية لطلاب المدارس المصرية

الاعدادية الخاصة (2011)"

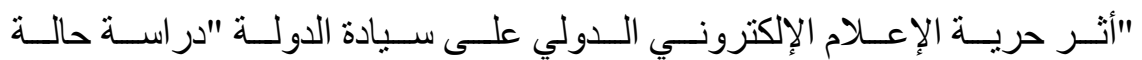

مصر(2012)" (1)

"اتجاهات النخبة نحو تأثنر مو اقع التو اصل الاجتماعى على الامن القومى المصرى :در اسة ميدانية (2015)".

-

" الألعاب الإلكترونية وهوية الطفل در اسة تحليلية وميدانية ( 2009)".

"استخدام مو اقع الانترنت التفاعلية وعلاقته بدعم ثقافة الحوار لدى الثباب المصرى

."(2010)

"المجتمع الافتر اضى والهوية :در اسة على الجمهور المصرى (2011)".

" هـل تـؤثر تكنولوجيـا الاتصـال على الهويـة الثقافيـة للمجتمع العربـي : رؤيـة نقديـة

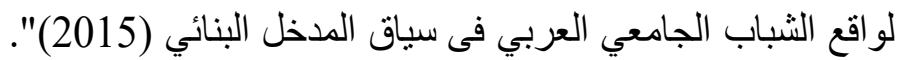

" استخدام الثباب المصــري لتطبيقات الدردشـة عبر الهاتف و علاقتهـه بمستوي ثقافة

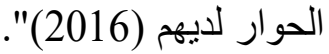

" دور الفـيس بـوك الـــعوي فـي نشـر التثقيـف الــيني لــدى الثــباب الجـامعي

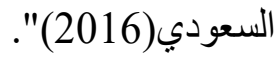


بحوث العلاقات العامة والاعلان فى مصر :الواقع واتجاهات المستقبل

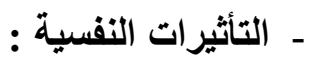

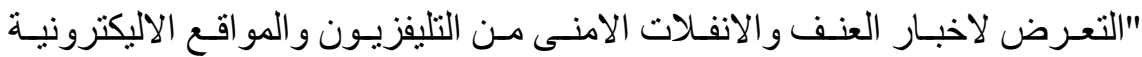
وتأثير ها على انفعالات الخوف لاى الجمهور المصرى (2011)".

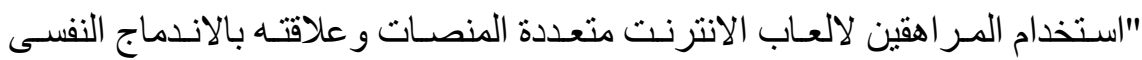
و الاداء الدر اسى لديهم (2015)".

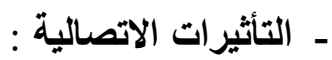

" نأثير استخدام شبكة الإنترنت على الهنتج الصحفي(2007)". " الدتغيرات المؤثرة على التفاعلية فى النثر الصحفى على شبكة الأنترنت :دراسة الصنّة

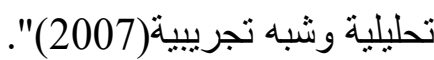

"ادوار مستخدمى المو اقع الاليكترونية فى صناعة المضامين الاعلامية (2008)" (2008). "تأثير الانترنت على الصحافة في سلطنة عمان (2008)".

"ادر الك الجمهور والقائم بالاتصـال للخدمات الاعلامية المقدمة عبر الهاتف المحمول

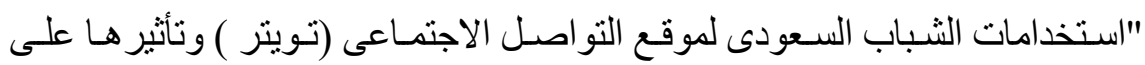

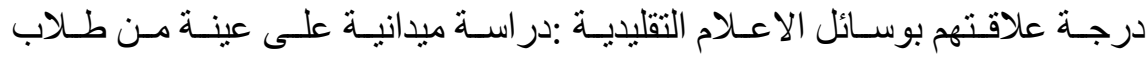
الجامعات الحكومية والخاصة فى مدينة الرياض(2015)". "التضليل الاعلامى وعلاقته بالاثار السلبية لثبكات التو اصل الاجتماعى (2015)".

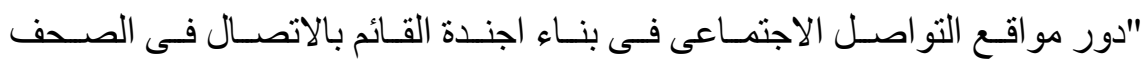
المصرية بالنسبة للاخبار و القضايا المحلية (2015)". "تأثير وسائل الاعلام الحديث على تتككيل اجندة وسائل الاعلام التقليدية (2016)". (4) اخلاقيات الممارسات الاتصالية عبر الاتترنت وتثريعاته:41

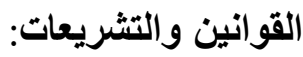

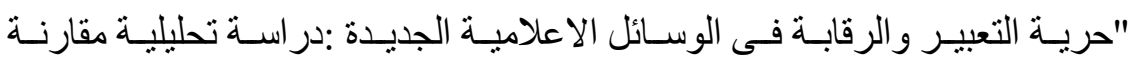

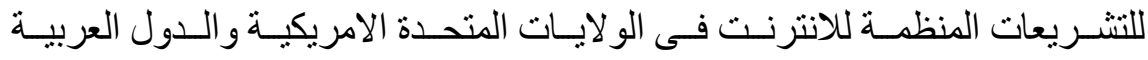
(2000) 
بحوث العلاقات العامة والاعلان فى مصر :الواقع واتجاهات المستقبل

"الرقابة على شبكة الانترنت :در اسة حالة دول الخليج العربى (2002)".

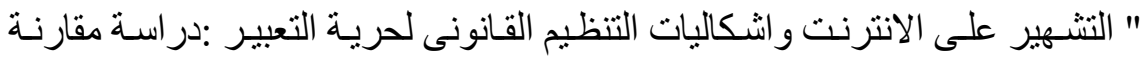

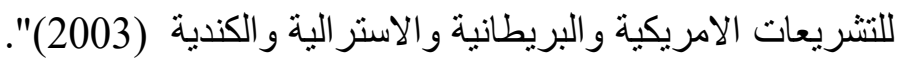

كمــاســتهدفت دراســات اخـرى التعـرف على اخلاقيـات العمـل الاعلامسى فـى البيئة

الاليكترونية الجديدة :

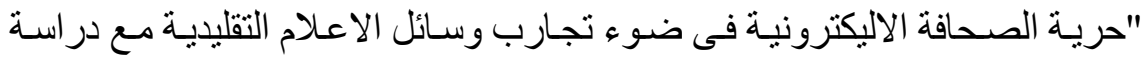

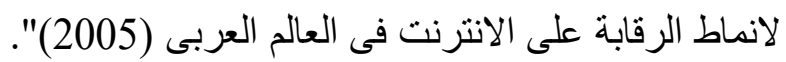

"اخلاقيات العمل الاعلامسى :در اسـة مقارنـة بين البيئة الاعلاميـة الرقمبـة و التقليديـة

$$
\text { " أخلاقيات الإعلام في عصر العولمة(2009)" الاعلام الجديد :النظام والفوضى (2009)" }
$$

"مصداقية المو اقع الصحفية الاليكترونية و علاقتها بدرجـة الاعتمـاد عليها كمـا ير اهـا

جمهور الصفوة الاعلامية المصرية :دراسة ميدانية (2011)".

"اخلاقيات نشرتعليقات القر اء فى المو اقع الاخباريـة وفى صفحاتها على الفيس بوك

:دراسة للمضمون ومعايير القائم بالاتصال فى النشر (2015)".

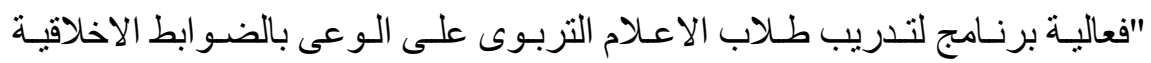

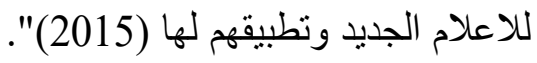

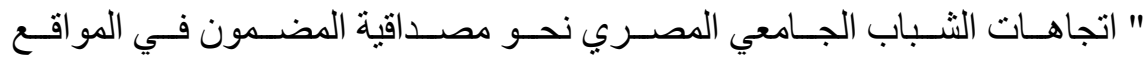

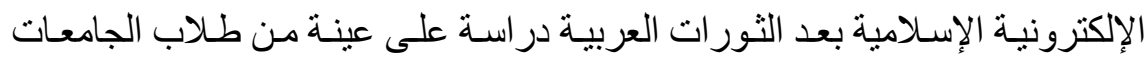

$$
\text { الإقليمية المصرية(2015)". }
$$

\section{وحليثا اتجهت الدراسات فى هذا المجال نحو منحى جديد :}

"السـخرية السياسـية عبـر مو اقـع الثــبكات الاجتماعبـة بـين الحريـة و المسـؤولية (

"ثقافة الخصوصية عبر مواقع التو اصـل الاجتمـاعى ببن مز ايـا الافصـاح عن الذات ومخاطره :دراسة فى توجهات الجمهور العام المصرى (2015)". 
بحوث العلاقات العامة والاعلان فى مصر :الواقع واتجاهات المستقبل

"فعاليـة برنـامج لتـدريب طـلاب الاعـلام التربـوى على الـوعى بالضـو ابط الاخلاقيـة

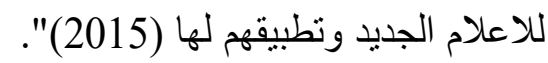

"تأثنير ات استخدام المعلنين لملفات تعريف الارتباط (الكوكيز) لتتبع المستهلك عبر شبكة الانترنت على حماية الحق فى الخصوصية (2015)".

(5)اسـتخدام الوســائل التفاعليـة الحديثة فـى مجـال الاعـلان و الاتصـالات التسـويقية

42: والتسويق الاجتماعى الوسيات

فى البداية تناولت الدراسات فى هذا المجال :

" تعـرض طـلاب الجامعـات للاعلانـات التليفزيونيـة و علاقتهـه باستخدامهم للانترنـت

$$
\text { والتليفون المحمول (2005)". }
$$

" استخدام شبكة المعلومات الانترنت كوسبلة اعلانيـة :در اسـة مقارنـة على عينة من

$$
\text { الثركات المصرية والدولية (2006)". }
$$

ثم اعلانات الهواتف المحمولة :

" اتجـاهـات الجمهـور نحو الإعلانـات عبر الهـاتف المحمول فـى عصـر العولمـة:

در اسة مسحية (2009)".

"اعلانـات الهواتـــ المحمولــة بــين :قبـول التكنولوجيــا الحديثــة ...او التخلـى عـن

$$
\text { الخصوصية(2015)". }
$$

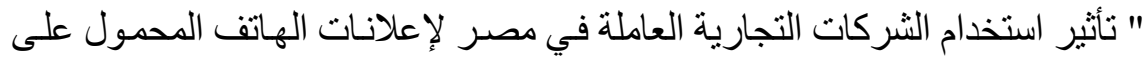

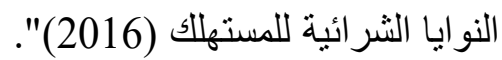

واعلانات شبكات التواصل الاجتماعى :

" العو امل المؤثرة على تجنب الجمهور المصرى لاعلانـات الفبس بوك و اتجاهـاتهم

نحو ها :در اسة مسحية على عينة من مستخدمى الفيس بوك لك (2014)".

"استخدام الثباب الجـامعى الفلسطينى للاعلانـات الاليكترونيـة عبر مو اقع التو اصلـل الاجتماعى والاشباعات المتحققة منها :در اسة وصفية (2016)".

"تـأثير اتصـالات العلامـة التجاريـة عبـر المواقع الاجتماعيـة على النوايـا الثــر ائية للمستهلك (2016)" التصن 
بحوث العلاقات العامة والاعلان فى مصر :الواقع واتجاهات المستقبل

تطوير صناعة الاعلان كان من المجالات الهامة:

"اثـر التكنولوجيـا الحديثـة فـى تطــوير اخـر اج العناصـر الجر افيكيـة فـى الاعــلان

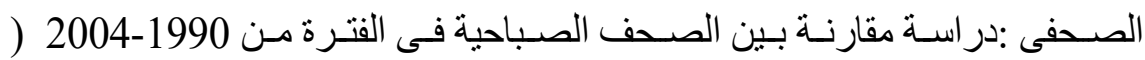

." (2006

واخلاقيات الممارسات الاعلانية عبر الانترنت :

" قو انين وأخلاقيات الإعلان عبر الإنترنت(2009)".

وفى اتجـاه مـوازى تناولت بعض الدر اسـات التسـويق الاليكترونسى بشـكل عـام او احـ

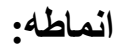

"التسـويق الاليكترونسى فى مصـر :در اسـة ميدانيـة على عينـة مـن الثـركات متعددة

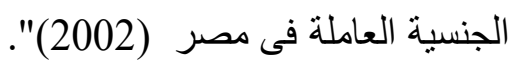

"الاسـتخدامات و الاثـباعات المتحققـة لمستخدمى التسـويق عبـر الانترنت بالسـعودية

"استخدامات و إثباعات ألعاب الفيس بوك ودور ها كوسيلة نسويقيَّة حديثة(2016)".

واستخدامها فى التسويق الاجتماعى:

"قضايا المجتمع كما تعكسها المدونات المصرية على الانترنت (2010)".

" الحملات الإعلامية عبر الإعلام الجديد رؤية مستقبلية لنموذج تفاعلي ( 2013)".

اواستخدام احد الادوات الاتصالية الخاصة بالانترنت فى اطار الاتصالات التسويقية :

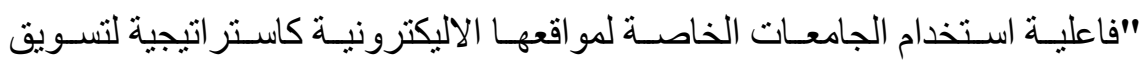

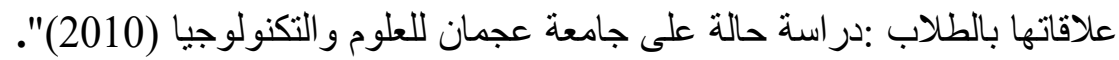

"اســـخدام الثـركات الاعلاميـة العـابرة للقـار ات لمو اقعهـا الاليكترونيـة فـى تسـويق

منتجاتها :در اسة تتبعية (2012)".

" التـرويج على الفيس بـوك: دور صـفحات الثــركات في التـرويج عـن منتجاتهـا

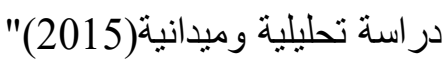

"فاعليـة اســتخدام شـبكات التو اصـل الاجتمــاعى فـى ممارســة الإتصــالات التسـويقية

للمنظمة :در اسة حالة على شركتى ايفون واوريفليم (2016)". 
بحوث العلاقات العامة والاعلان فى مصر :الواقع واتجاهات المستقبل

ثم اتجهت الدراسات لتناول اساليب محددة من التسويق الاليكترونى ومنها:

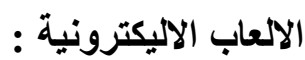

"تسـويق الماركـات و المنتجـات عبـر الالعـاب الاليكترونيـة Advergaming در اسـة

تطبيقية على عينة الاطفال و الثباب المصرى(2010)".

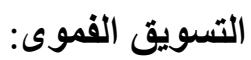

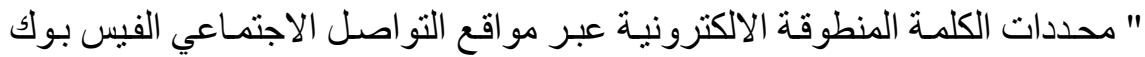

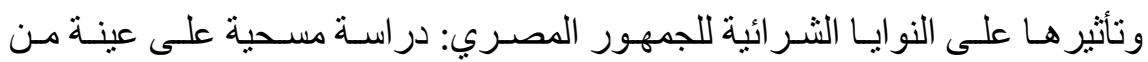

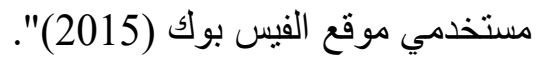

المواقع التسويقية:

" العلاقة بين فاعلية المو اقع التسويقية عبر الانترنت والاتجاه نحو المنتجات المعلنـة

عنها بالتطبيق على عبنة من الثباب المصري (2015).

43: استخدام الاعلام الجديد فى مجال التسويق السياسى (6)

تنقسم الاراسات فى هذه الجزئية الى قسمين:

القسم الاول يختص بالدراسات التى تناولت دور الاعلام الجديد بثكل عام فى التسويق

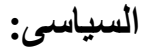

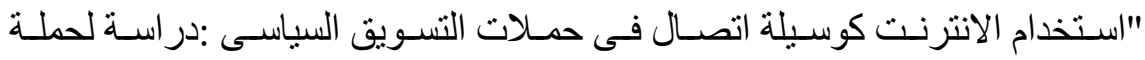

انتخابات الرئاسة الامريكية 2008 (2009)" .

"استخدامات جماعات العنف لثبكة الانترنت :در اسة فى تحليل خطاب تنظيم القاعدة (2014)".

"دور العلاقات العامـة الاليكترونية في ادارة الحملات السياسبة :الانتخابـات الرئاسية

$$
\text { المصرية لعام } 2014 \text { نموذجا (2015)". }
$$

امـا القسم الثانى فيتنـاول دور احد الادوات الاتصـالية بالانترنت فى التسويث السياسى وذلك على النحو التالى : التصى

" اسـتخدام مو اقـع التـدوين المصـغر تـويتر في تغطيـة الانتخابـات التشـريعية 2010: در اسة تحليلية (2011)". 
بحوث العلاقات العامة والاعلان فى مصر :الواقع واتجاهات المستقبل

"توظيــ الأحـز اب والقـوى السياسـية المصـرية للمواقـع الالكترونيـة فـى تسـويق

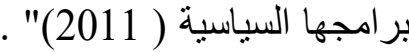

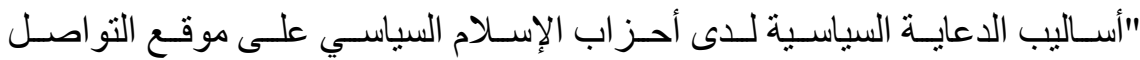

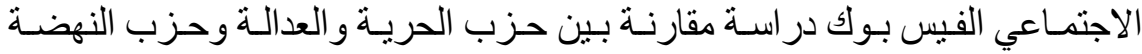

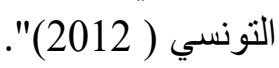

"علاقـة مو اقع الثـبكات الاجتماعيـة بالمشـاركة السياسـية في الانتخابـات البرلمانيـة

المصرية 2012/2011 بالتطبيق على موقع فيس بوك :در اسة ميدانية (2012)".

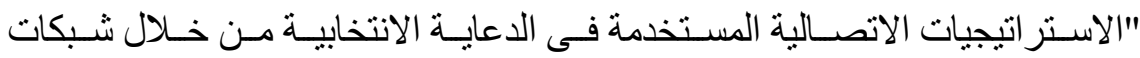

التو اصل الاجتماعى :در اسة على الانتخابات المصرية 2014(2015)".

"توظيف مو اقع التو اصل الاجتمـاعى (الفيسبوك)فى الدعايـة الانتخابية وتأثير هـا على التى

اتجاهات وقر ار ات الناخبين نحو المرشحين (2016)".

(7) استخدام الاعلام الجديد فى مجالى الاعلام الدولى وتثكيل الراى العام:44

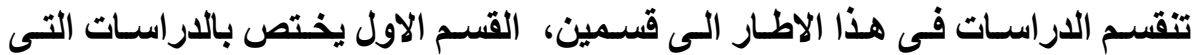

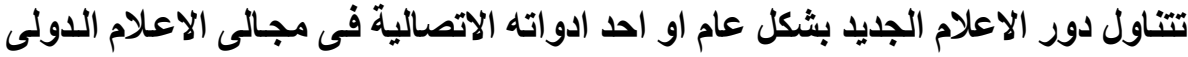

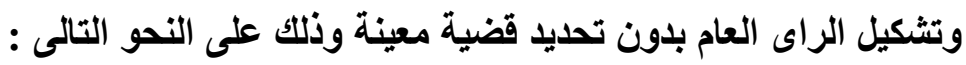

"أثز استخدام وسائل الاتصـال الحديثة في تكوين الر أي العام المصري تجاه القضـايا

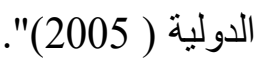

"دور الانترنت فى تنمية الوعي السياسي لدى الثباب السوري در اسـة تطبيقية على مو اقع التواصل الاجتماعي (2013)".

"تصور ات الاعلاميين فى وسـائل الاعلام الاليكترونيـة الامار اتيـة لادوارهم المهنيـة و العوامل المؤثرة فيها (2013)".

"الاسـتر اتيجيات الاتصــالية للابلوماسـية العامـة الاسـر ائليلية عبـر الانترنــت :در اســة تحليلية (2015)".

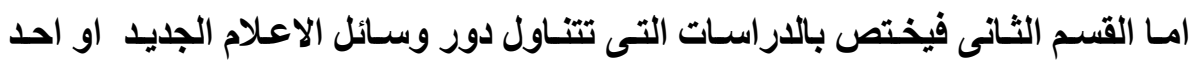
هذه الوسائل فى تثكيل اتجاهات الجمهور نحو قضية معينة وذلك على النحو التالى :

"دور الصحف الاليكترونية السعودية فى التوعية بالقضايا الصحية (2011)" 
بحوث العلاقات العامة والاعلان فى مصر :الواقع واتجاهات المستقبل

"اتجاهـات الـر أى العـام الالكترونـي نحـو متغيـرات التحـول الـديمقر اطى بمصـر بعد إعلان خارطة الطريق 3 يوليو 2013 در اسة مسحية (2016)".

• شبكات التواصل الاجتماعى :

" الثبكات الاجتماعيـة وتعزيز مو اطنـة الاقليـات النوبيـة في مصر رؤيـة أثنوجر افيـة

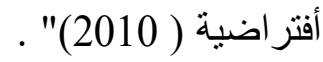

" دور وسائل الاعلام الاجتماعية فى التعبئة السياسية قبيل ثورة 25 يناير (2011)". " دور الثبكات الاجتماعية فى تكوين الر أى العام فى المجتمع العربي نحو الثورات

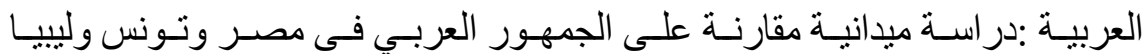

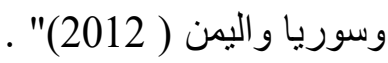

"دور شبكات التو اصل الاجتماعى فى نوجيه الر ایى العام نحو الاحداث السياسية فى الري مصر :در اسة حالة على الانتخابات الرئاسية 2012(2012)".

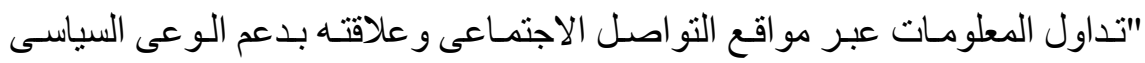
لدى الثباب المصرى الجامعى (2012)". " استخدام تويتر لرصد المز اج العام للمجتمع فى فتر ات الإضطر ابات أحداث محمد

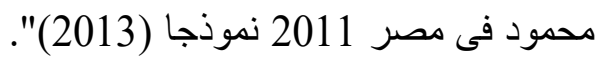
" دور مو اقع الثبكات الاجتماعية فى المشاركة السياسية للثباب اليمني ( 2013) ". " اتجاهات الر أى العام المصري نحو الموقف الامريكي الرسمي من ثورة 30 يونيو ."2014) 2013

"دور مو اقـع التو اصـل الاجتمــاعى فـى نتـكيل اتجاهـات النـاخبين خـلال الانتخابـات الرئاسية المصـرية 2014:در اسـة ميدانيـة على عينـة مـن الجمهور العـام فـى مصـر ."(2014)

"دور التعرض للفيس بوك فيى المشـاركة السياسية لمستخدمى المجمو عات السياسبة

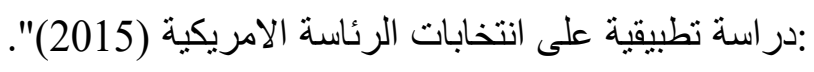
"العلاقة بين التعرض للمضـامين السياسية بالصحف و القتوات الفضـائية المتاحة عبر

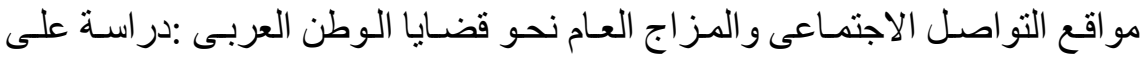
الجمهور المصرى والسعودى (2015)". 
بحوث العلاقات العامة والاعلان فى مصر :الواقع واتجاهات المستقبل

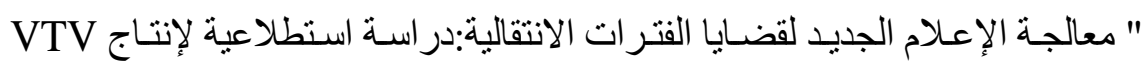

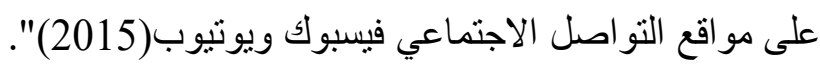

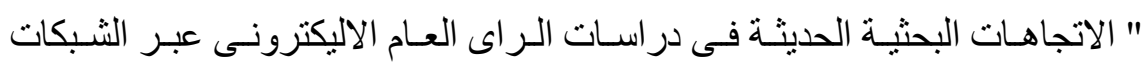

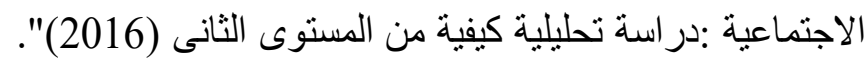

" دور الفـيس بـوك الـــعوي فـي نشـر التثقيـف الــيني لــدى الثــباب الجـامعي

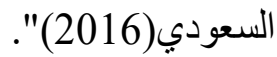

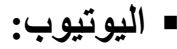

" أثر مقـاطع بوتيوب على تتـكيل معـارف واتجاهـات الفتـاه السـعودية نحو احداث

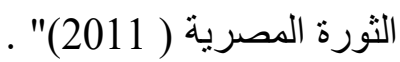
"أغانى اليوتيوب ومشاركة الثباب فى المجال العام(2013)".

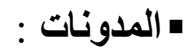

"المدونات كأداة اتصـال تفاعلي في المشـاركة السياسية :در اسـة تحليلية لأطروحات

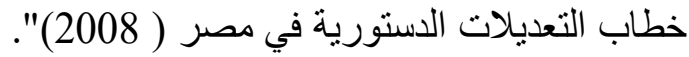
" العلاقة بين المدونات الإلكترونية والمشاركة السياسية فى مصر ( 2010)" . " تـأثنبر معالجـة المو اقـع الإعلاميـة الالكترونيـة و المـدونات لقضـايا العـالم العربـي على آراء الجماهير المتفاعلة (2014)". • الصحف الاليكترونية : " العلاقة بين اعتمـاد الجمهور العر اقي على الصـحف الالكترونيـة واتجاهـاتهم نحو قضايا الإصلاح الاقتصادى و الاجتماعي (2014)".

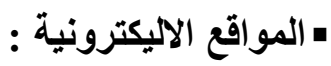

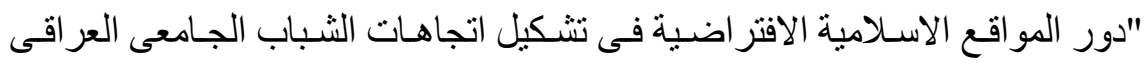
نحو القضايا الدينية المعاصرة (2015)".

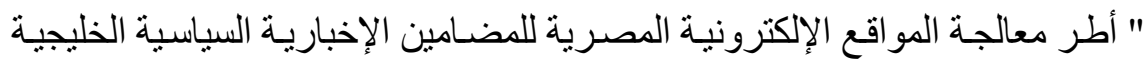

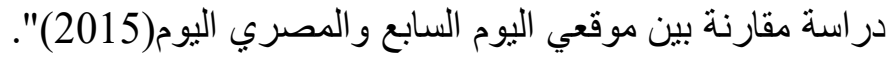


بحوث العلاقات العامة والاعلان فى مصر :الواقع واتجاهات المستقبل

(8) اسـتذام الوسـائل التفاعليـة الحديثة (الانترنـت، احد ادواتـه الاتصـالية، التليفون

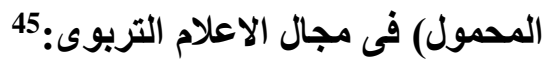

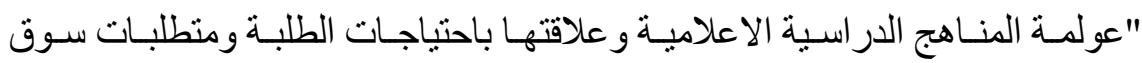
العمل :در اسة تقويمية على منهاج الرؤية الجديدة لجامعة الامار ات الات (2009)".

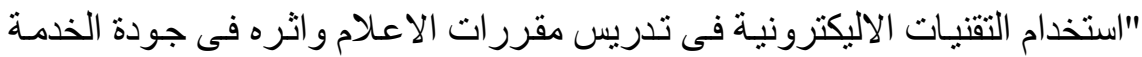
التعليميـة :در اسـة ميدانيـة على اعضــاء هيئة التـدريس وطـلاب الجامعـة الامريكيـة بالقاهرة (2011)".

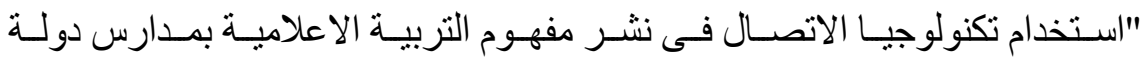
الامار ات العربية المتحدة (2013)"

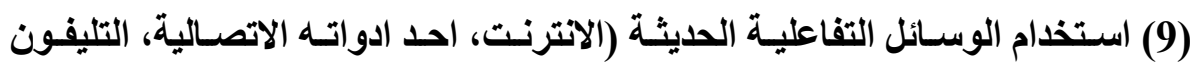

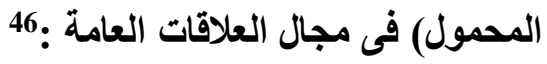

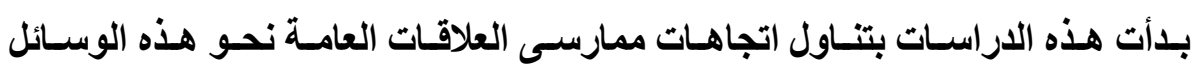

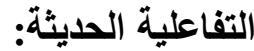

"اتجاهـات ممارسى العلاقات العامـة نحو استخدام الانترنت كوسيلة اتصـالية :در اسـة

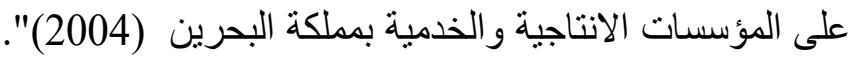

ثم تحولت الى استخداماتها في ممارسـة انشطة العلاقـات العامـة والتأثيرات المترتبـة على ذلك :

"دور التكنولوجيا الجديدة فى العلاقات العامـة :دراسة تطبيقية على شركة المقاولون

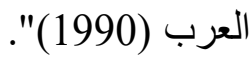

"استخدام شبكة المعلومات الانترنت في مجال العلاقات العامـة :در اسـة تطبيقية على بعض المؤسسات الامار اتية (2007)" .

"تأثثر استخدام تكنولوجيا الاتصـال الحديثة على الاستر اتيجيات الاتصـالية للعلاقات العامة فى المؤسسات السعودية (2012)".

"استخدام الانترنت فـى ممارسـة أنشطة العلاقات العامـة :در اسـة تطبيقيـة على عينـة

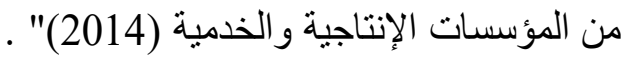

"استخدام العاملين فى العلاقات العامة بشركات النفط الليبية لتقنيات الاتصـال الحديثة 
بحوث العلاقات العامة والاعلان فى مصر :الواقع واتجاهات المستقبل

و علاقته بالجو انب الإدارية والإتصالية(2015)".

"دور المو اقع الالكترونية فى تسويق الاحداث الخاصة :دراسـة تطبيقية على عينة من المو اقع الحكومية والخاصة والاجنبية (2015)".

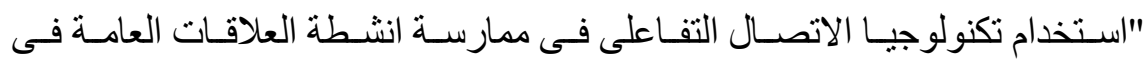

المنظمات العاملة فى اليمن (2015)"

"استخدام العلاقات العامة الالبكترونيـة لتحقيق الرضـا الوظيفى للعاملين فى الثـركات

المتعددة الجنسيات العاملة فى مصر (2015)".

" إدارة العلاقات مع العملاء عبر الصفحات الرسمية للجامعـات الإمار اتيـة على موقع الفيسبوك در اسة تحليلية (2015)".

"اســـخدامات وسـائل الاتصــال الحديثـة بـإدارات العلاقـات العامـة فـي المؤسســات

التعليمية للتواصل مع جماهير المؤسسة (2016)".

واستخدامها فى مجال العلاقات العامة الدولية :

"استر اتيجيات الاتصال فى العلاقات العامـة الدولية :در اسـة على المو اقع الاليكترونيـة

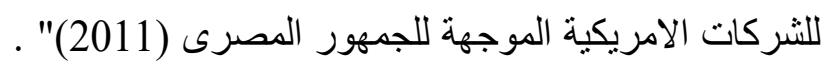

" صــاعة العلاقـات العامـة الدوليـة :در اســة تحليليـة لعينـة مـن المو اقـع الالكترونيـة لكبرى وكالات العلاقة العامة الدولية (2013)".

اخلاقيات العلاقات العامة :

"اخلاقيات ممارسات العلاقات العامة على شبكة الانترنت (2009)".

"اثر اسـتخدام الانترنـت على اخلاقيـات ممارسـة العلاقـات العامـة :در اسـة نطبيقيـة

\section{واستخدامها فى برامج العلاقات العامة : \\ اولا : فى برامج المسئولية الاجتماعية : 47}

" تأثثير استخدام بر امج المسئولية الاجتماعية عبر الانترنت على بنـاء سمعة المنظمـة

"اتصـال المسئولية الاجنماعيـة عبر مو اقع منظمـات الاعمـال على الانترنت :در اسـة 
بحوث العلاقات العامة والاعلان فى مصر :الواقع واتجاهات المستقبل

تحليلية لعينة من مواقع منظمات الاعمال الدولية على الوب(2012)".

48: ثنانيا :فى بر امج ادارة سمعة المنظمة

"دور الاتصـال عبر الموقع الاليكترونى للمنظمـة فى بنـاء السمعة الجيدة :دراسـة على الجى

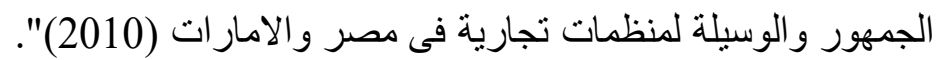

"دور المواقع الاليكترونية فى بناء سمعةالمنظمة (2015)".

49: ثنالثا : فى بر امج ادارة الازمات

"الاعتمـاد على الثبكات الاجتماعيـة خـلال أزمـة الاتصـالات في ثورة 25 ينـاير فىى

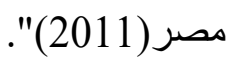

"معالجـة مو اقع الصـحف الاليكترونيـة المصـرية للازمـات السياسية العربيـة :در اســة تحليلية (2014)".

"استخدام الثـاب القطرى لوسـائل التواصل الاجتمـاعي اثثاءالأزمـات: دراسـة مسحية

"تقييم فاعليـة توظيف تكنولوجيـا الاتصـال التفـاعلى فـى ادارة الازمـات التى تو اجـهـ المنظمات العاملة فى مصر (2016)".

"اسـتر اتيجيات الاسـتجابة للازمـات التـى تسـتخدمها الاحـز اب السياسـية فـى وسـائل الاعلام الاجتماعية المصرية :الاعلان الدستورى كدراسة حالة (2016)".

50: رابعا :فى برامج ادارة الصورة الذهنية

"الصورة الذهنيـة لوسـائل الاعلام الجديد ودورهـا الفاعل فى تغيير الواقع الاعلامى بـى

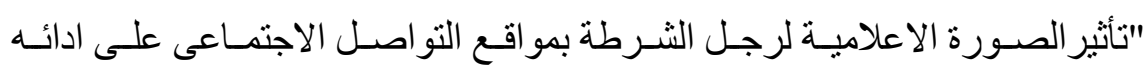
المهنى والمجتمعى (2014)".

"صـورة التيـار السـلفى فى خطاب المو اقع الاليكترونيـة للصحف المصرية بـالتطبيق

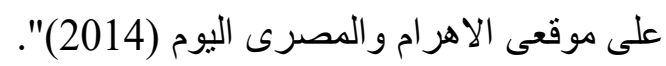

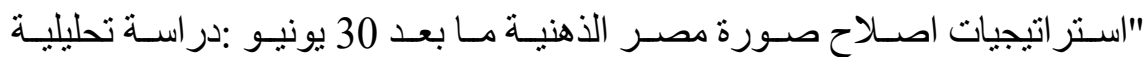
لتغريدات وزارة الخارجية المصرية و المتحدث الرسمى للوزارة (2016)". 
بحوث العلاقات العامة والاعلان فى مصر :الواقع واتجاهات المستقبل

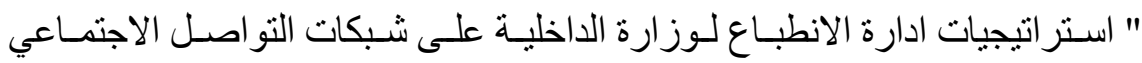

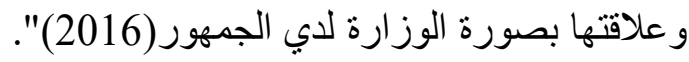

51: استخدام الاعلام الجديد فى اطار الاتصالات المؤسسية بدأت الاراسات فى هذا المجال بدر اسة :

" مجـالات اســخدام شـبكة المعلومـات الدوليـة الانترنــت فـى الانثـــة الاتصــالية

"قاس فاعلية تقنيات الاتصال الحديثة المستخدمة بالجامعة المفتوحة (2012)".

فى حين تناولت حديثا بعض الاراسات احد الادوات الاتصالية بالاتترنت وتوظيفها من قبل نمط معين من المنظمات في الاتصالات المؤسسية:

"استخدام النقابات المهنية لمو اقعها الالبكترونية فى تحقيق اهدافها (2015)".

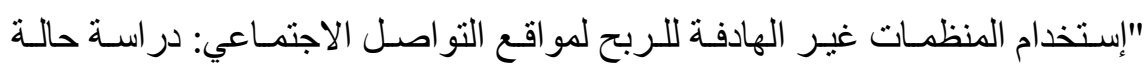
إستخدام صفحات الفيسبوك (2015)".

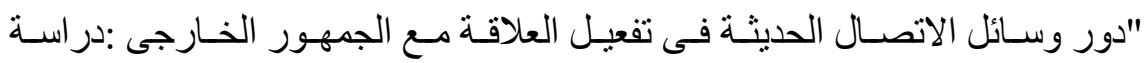
تطبيقية على المؤسسات الحكومية فى دولة الامار ات (2016)"

التعليق على العرض السابث من حيث :

الفترات الزمنية التى تركز فيها الاتتاج العلمى فى مجـال الاعلام الجديد وتوظيفهـ فى

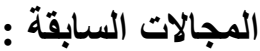

بدأت غالبية هذه الدر اسات فى عام 2000ومـاز الت مستمرة حتى الان وذللك على النحو

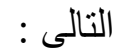

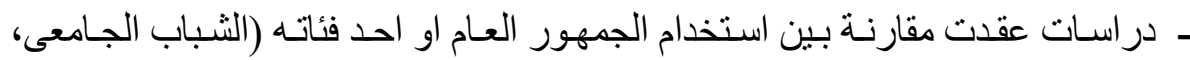

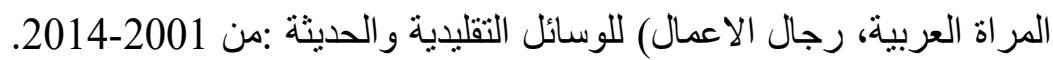

ـ در اسـات تتنـاول استخدامات الجمهور العـام او احد فئاتهـ(الاطفال، المر اهقين، الثباب

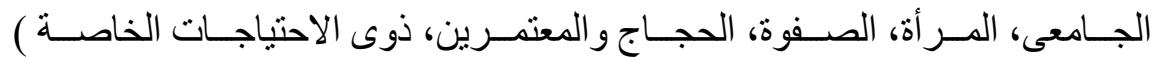

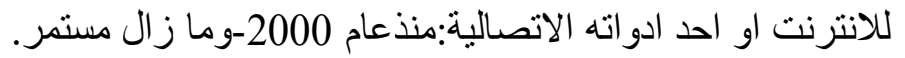

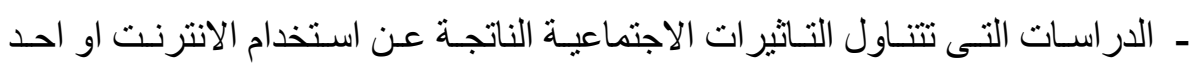


ادو اتـه الاتصـاليه (على التفاعل الاسـرى، اكتسـاب المعلومـات، العلاقات الاجتماعيـة،

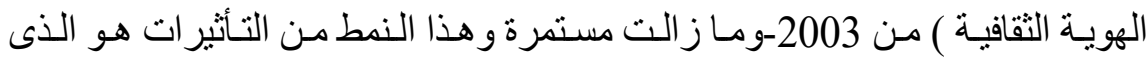

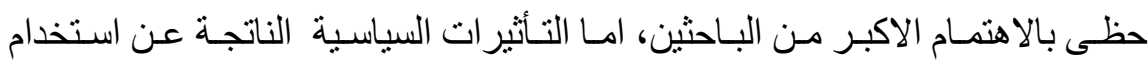

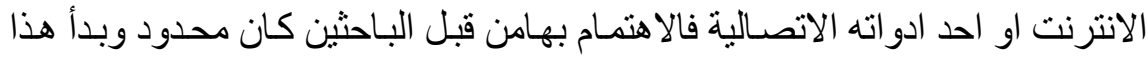

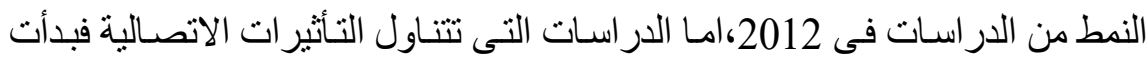
من 2007.

ـ ـ وعلى الـرغم مـن ان الدراسـات التـى تتـــاول اخلاقيـات الممارسـات الاتصـالية عبـر

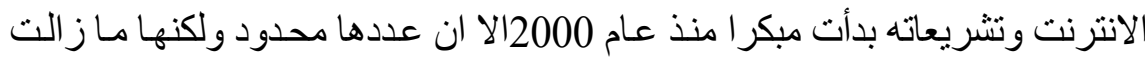

$$
\text { مستمرة حتى الان. }
$$

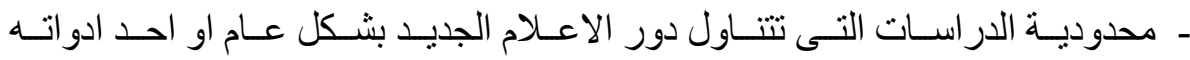
الاتصـالية فى مجالى الاعلام الدولى وتشكيل الراى العام بـدون تحديد قضية معينـة

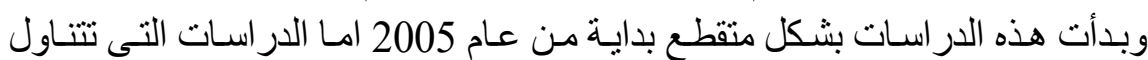

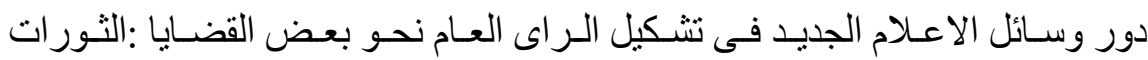

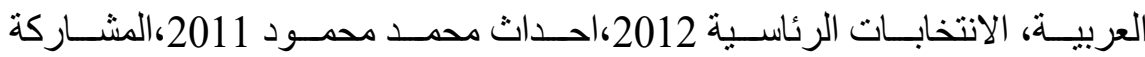

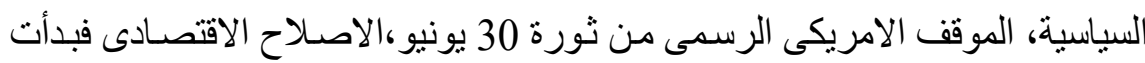
منذ2008 وما زالت مستمرة وبكثافة .

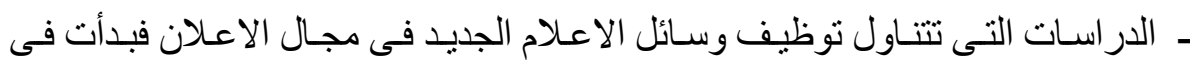

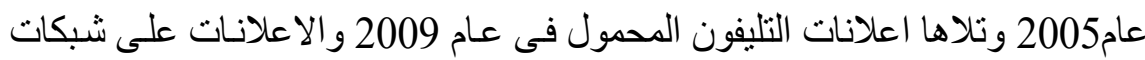

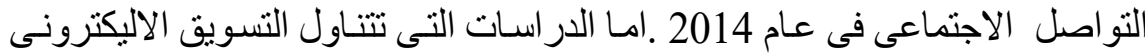
فبدأت فى عام 2002 وما زالت مستمرة فى طرق مجام فالات جديدة . ـ ـ ندرة الدر اسـات التى تتنـاول توظيف الاعلام الجديد فى مجـال الاعلام التربوى وبدات

$$
\text { هذه الدر اسات فى لـ } 2009 .
$$

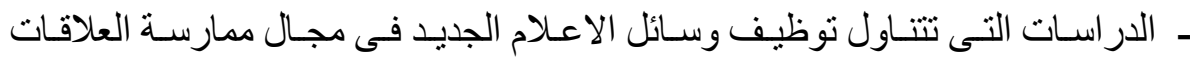

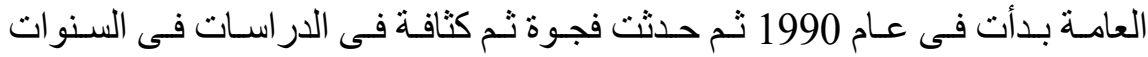

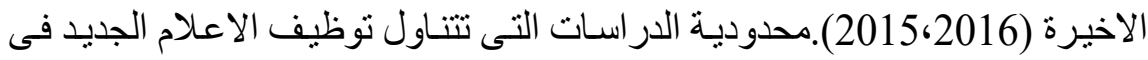

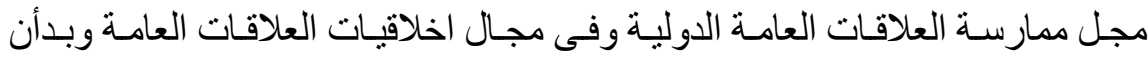

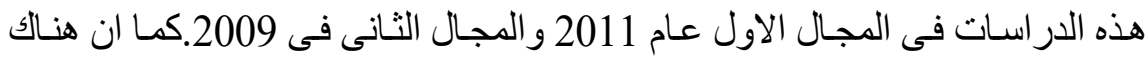

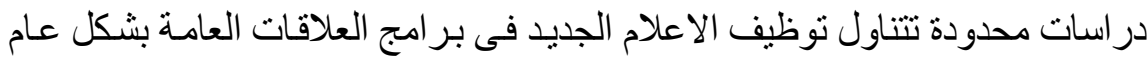

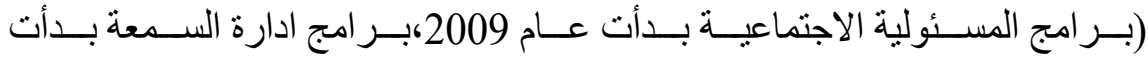


بحوث العلاقات العامة والاعلان فى مصر :الواقع واتجاهات المستقبل

2010×بـر امج ادارة الازمسـات بـــأت 2011،بـرمج ادارة الصــورة الذهنبـة بــأت

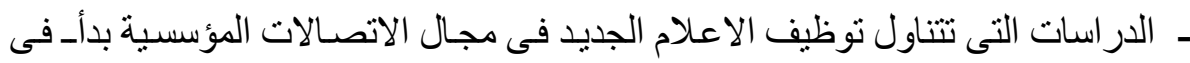

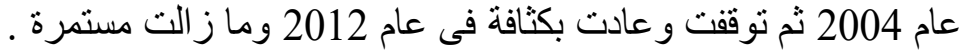

من حيث نوع الاراسات ومنهجها:

معظم الدراسات تنتمى الى الدراسـات الوصفية،و لا توجد اية در اسـات تجريبية.كما

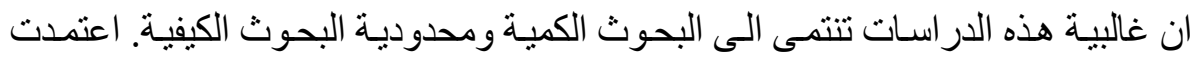

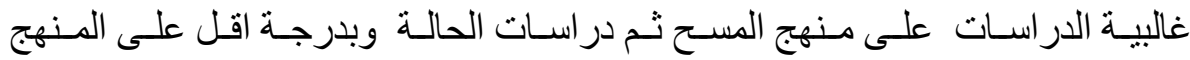

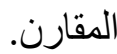

من حيث ادوات جمع البيانات ومجتمع الاراسة والعينة :

استخدمت النسبة الاكبر من الدر اسـات استمارة الاستقصـاء لاستطلاع ار اء عينـة

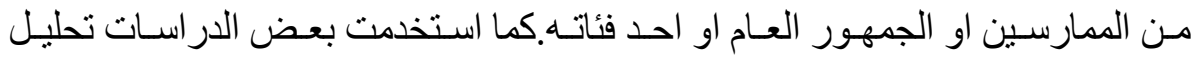

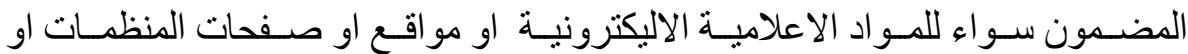

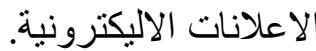

محساور الروئية المستقبلية المقترحة لتطوير الدراسـات العربيـة بشكل عام والمصرية

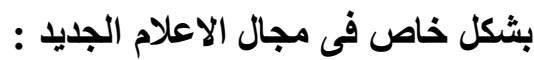

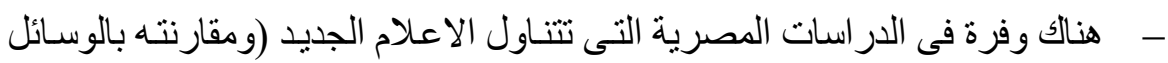

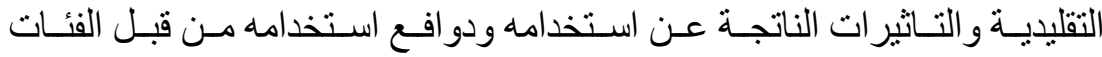

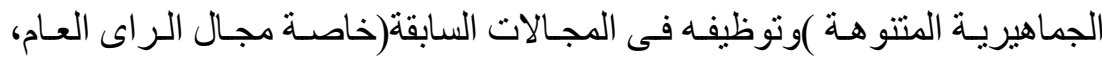

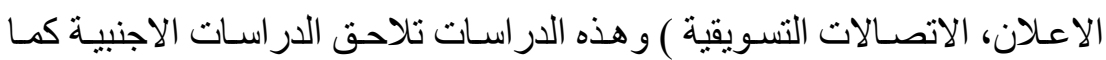

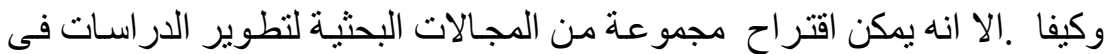

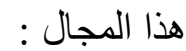

- - دور الثبكات الاجتماعية في دعم سمعة الثركات أثناء الأزمات.

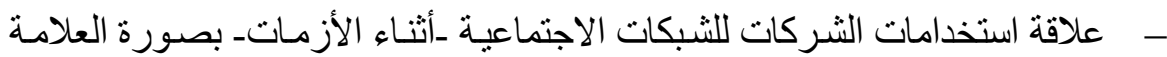

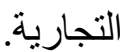

- ـ اسـتخدامات وسـائل الإعـلام الاجتماعيـة: دراسـة مقارنـة بـين المنظمـات الربحيـة

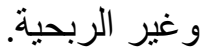
ـ ـ توظيف المو اقع الإلكترونية في إدارة هوية المنظمات المدنية. 
بحوث العلاقات العامة والاعلان فى مصر :الواقع واتجاهات المستقبل

- ـ تكنيكات إستخدام الصور و الرموز المرئية في مواقع التواصل الإجتماعى لتشكيل مو اقف المصريين تجاه القضايا الإجتماعية والسياسية .

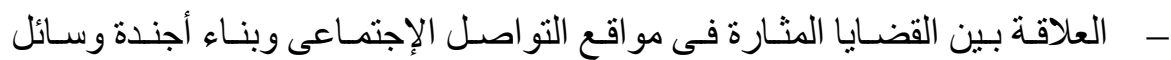
الإعلام التقلبدية.

- ـ تقييم فعالية صفحات الأجهزة السيادية على مواقع التواصل الإجتماعى.

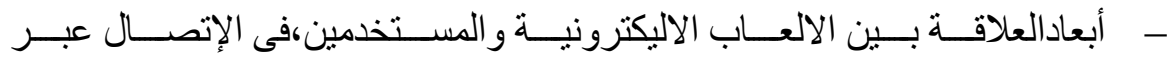
النقافات.(الابعاد النفسبة ـ الإقتصادية ـالاجتماعية ـالثقافية للمستخدمين ). - - توظيف الانترنيت فى العملية التعليمية.

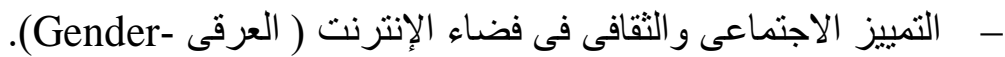

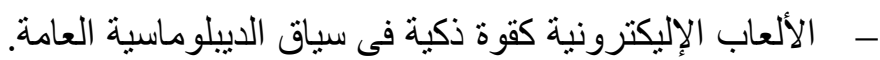
- - ـ - إستخدامات الثبكات الاجتماعية فى المجال السياسي العام.

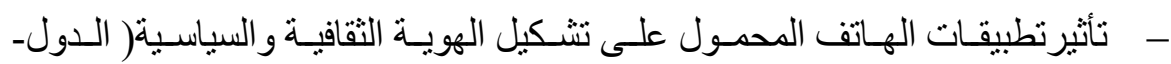

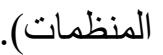
- - ـ الإستخدامات الثقافية للاعلام الجديد وثقافة المشاركة فى الثبكات الإجتماعية. - - مبناء رأس المال الإجتماعى عبر فضاء الألعاب الإليكترونية. - - مرية المستخدم فى فضاء الإنترنت. - - مصداقية المستخدم فى فضاء الإنترنت. - - - المو اقع الاخبارية فى فضاء الانترنت. - - الإنقسام الرقمى فى بيئة الإنترنت كأحد تأثثير ات الإنترنت على الإنى المستخدمين. - المدخل الإقتصادى السياسى للألعاب الإليكترونية.

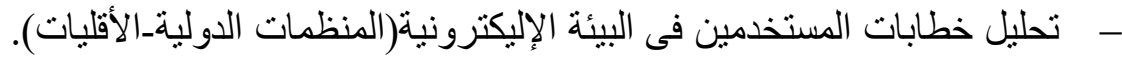

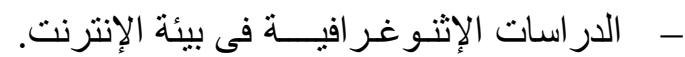
- - تحليل إستخدامات كامبر ا الوب. -

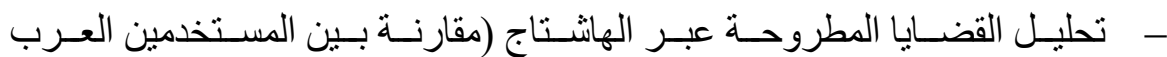

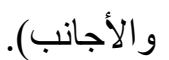

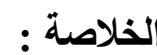

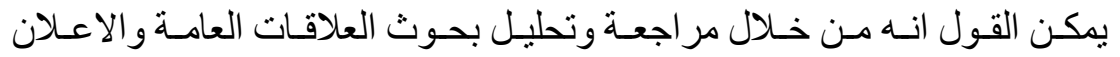

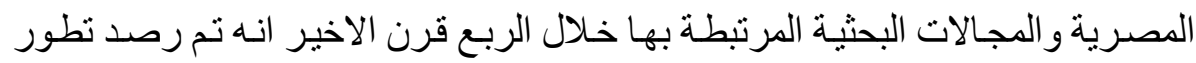




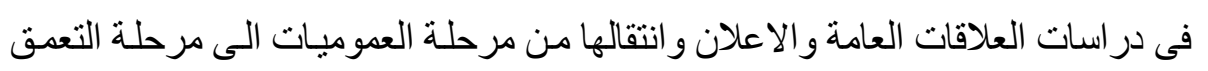

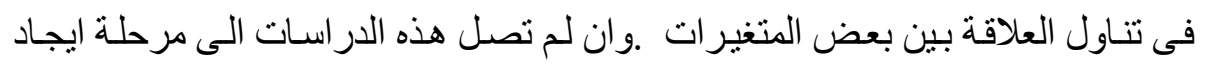

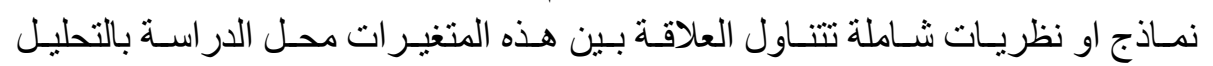

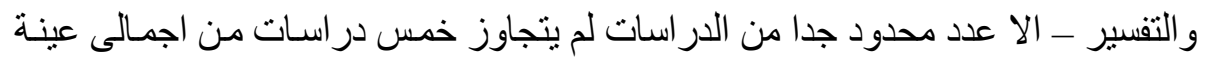

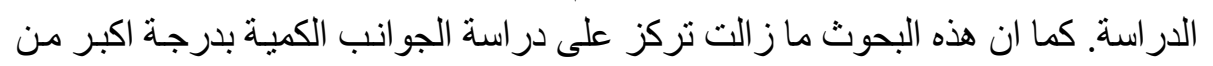

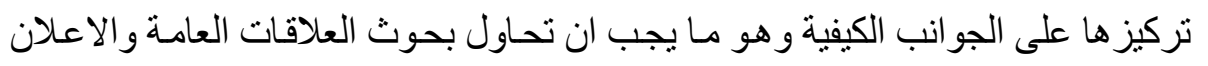

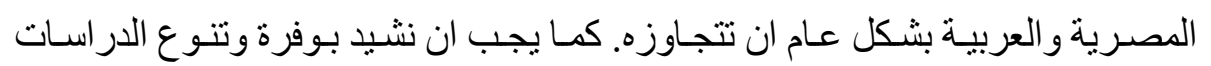

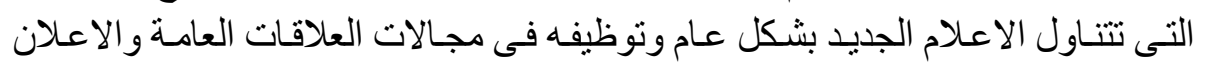

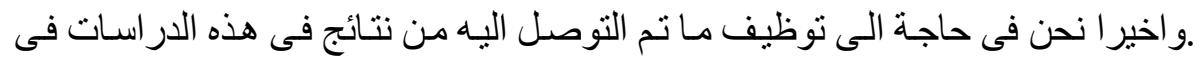
و اقع الممارسة ليتم الاستفادة الفعلية منها وتحقق الهدف الرئيسى الذى اجريت من اجلى الجله. 
1- Rebert L. Bangert, Lawrence M.Runder,Meta-Analysis in educational research,(London:BMJ publishing group, 2010), p.190.

2 - سلوى العو ادلى ،الاتجاهات الحديثة فى در اسات التسويق الاجتماعى ،المجلة العلمية لبحوث قسم

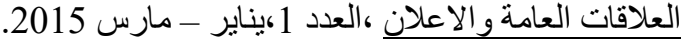

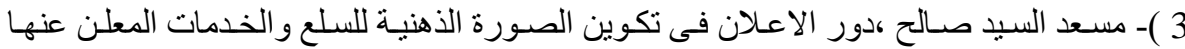

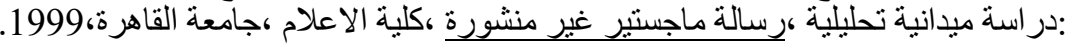

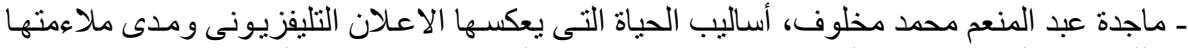

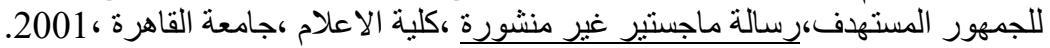

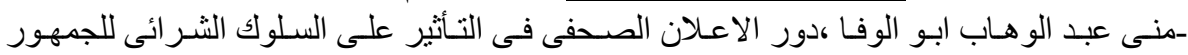

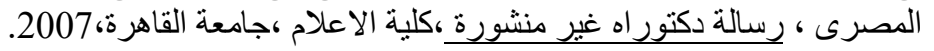

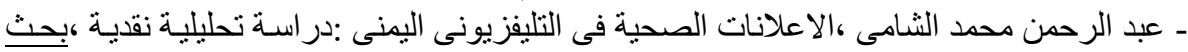

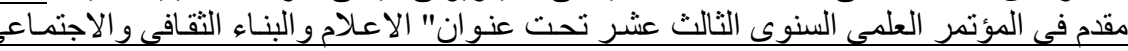

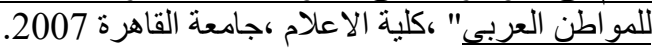

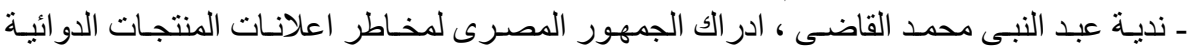

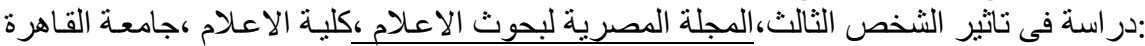

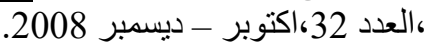

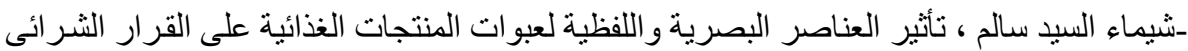

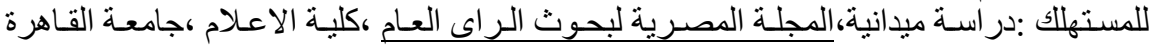

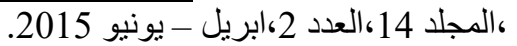

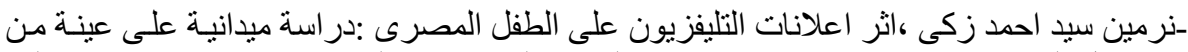
الاعفال المدارس الابتدائية من سن اعلات 12-1 فى القاهرة الكبرى ،رسالة ماجستير غير منشورة ،كلية

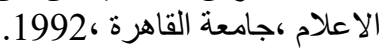

ـالهام يونس احمد ،تأثير الاعلانات التلافزيونية الأنية على الحصيلة اللغويـة للطفل ، رسالة ماجستير غير

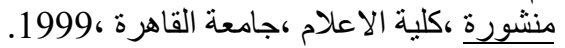

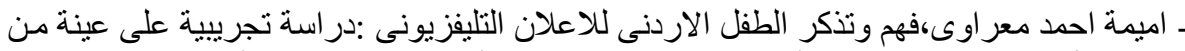

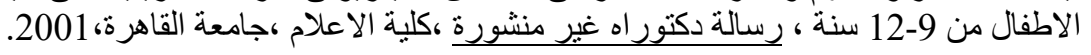

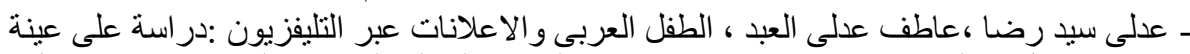

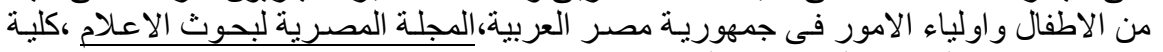

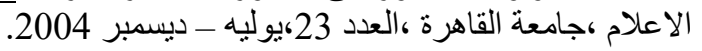

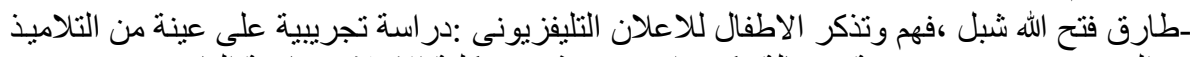

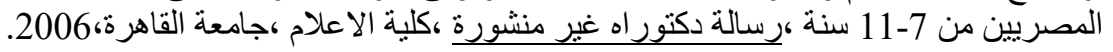

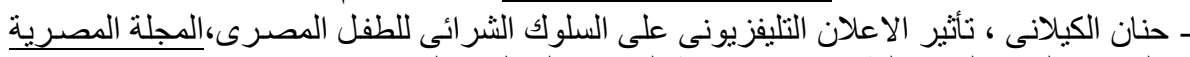

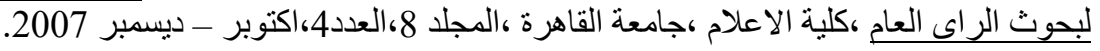

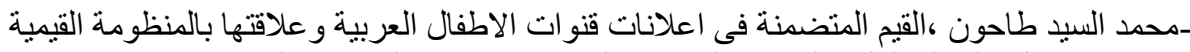

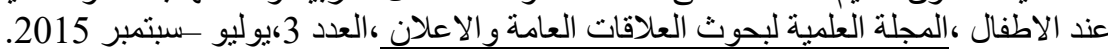

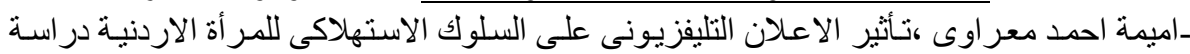
ميدانية ، رسالة ماجستير غير منشورة ،كلية الاعلام ،جامعة القاهرة، 1997. 
ـ سلوى العو ادلى ،تأثير الاعلان التليفزيونى على السلوك الثرائى للمر أة المصرية ، رسـالة دكتور اه

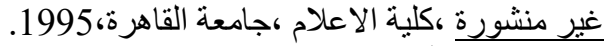

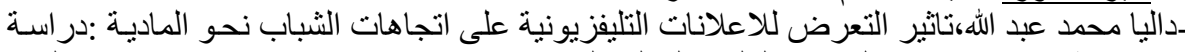

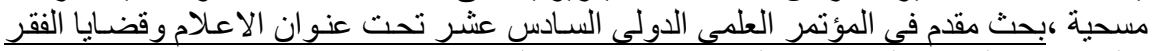

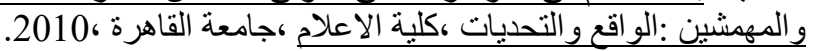

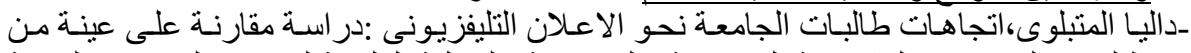

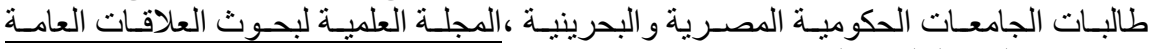

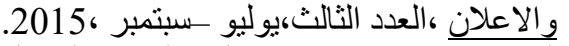
-خالد شاكر احمد جاويش ،تمثيل معلومات الرسئل الاعلانية المتناسقة لأى الجمهور :دراسة تجريبية

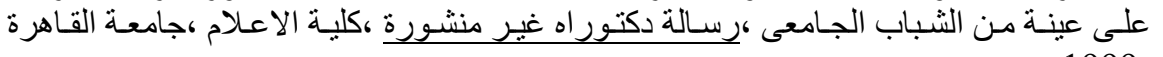
.1999، ـ هبة مسعد احمد ،تأثير التتافر المعرفى على اتجاه المستهلك وسلوكه :در اسـة تطبيقية على استخدام

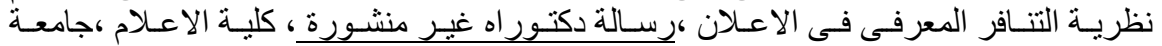

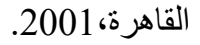
ـ داليا عبد الله ، اتجاهات الجمهور المصرى نحو الإعلانات التلافزيونية المثيرة للجدل واستجاباتهم نحوها، المجلة العلمية لقسم العلاقات العامة والاعلان ،كلية الاعلام ،جامعة القاهرة ،العدد 5،يناير

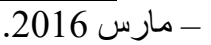

ـــــ العزيز عبد الستار تركستانى ،تأثنير الاعلان التليفزيونى الدولى على الجوانب الاجتماعيـة

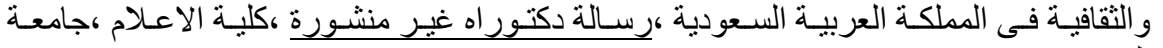

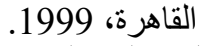
ـسلوى العو ادلى ،الاعلان وثقافة الاستهلاك فى عصر العولمة ،بحث مقدم في المؤتمر العلمى تحت

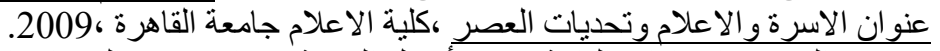

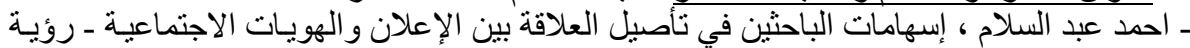
نظرية،المجلة العلمية لقسم العلاقات العامة والاعلان ،كلية الاعلام ،جامعة القاهرة ،العدد 5،يناير

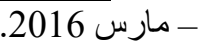

4 ) - محمد رضـا الجمـال ،تقويم اسـاليب الاعـلان التليفزيونى فـى مصـر ، رسـالة ماجسنتير غير

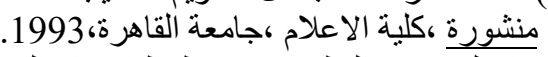

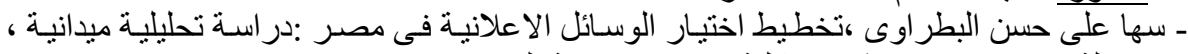

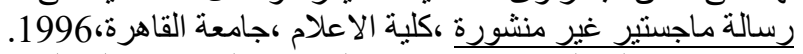

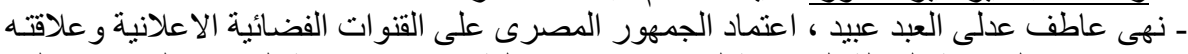

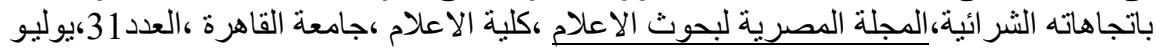
- سبتمبر 2008. ـ مروة محمد نبيل عبد المنعم ، مكانة اللافتات الاعلانية بالمناطق الاثرية في مصر قطاع الاعلية النحاسين

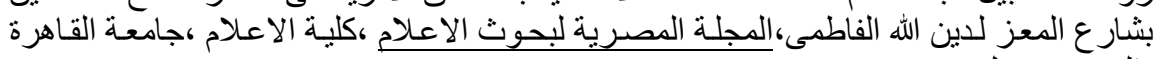

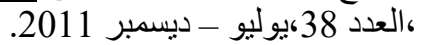

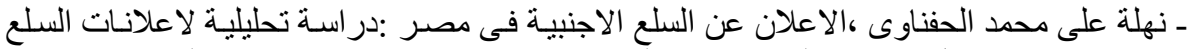

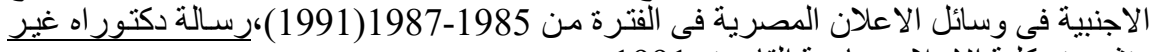

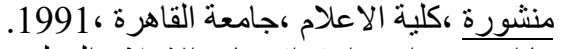

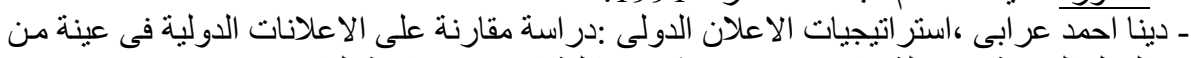

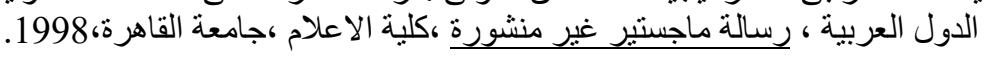


ـ منسى عبد الوهاب ابو الوفا ،السياسـات الاعلانيـة للمؤسسات الصحفية المصرية :دراسـة تحليلية

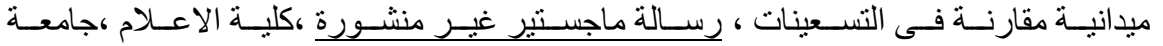

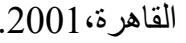

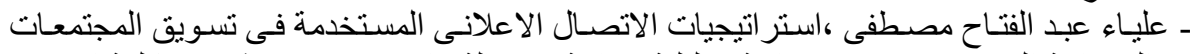

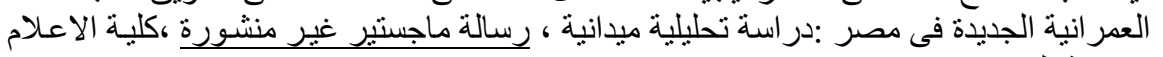

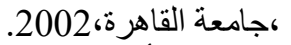

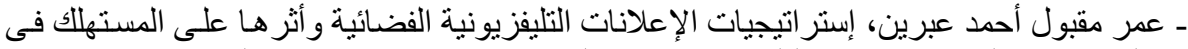

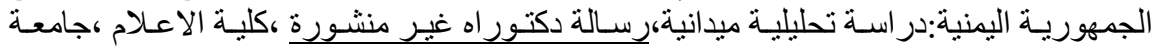

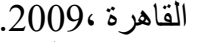

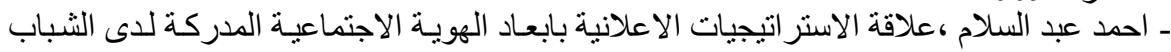

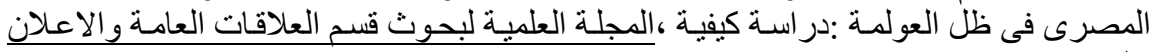

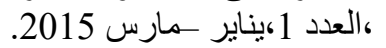
5 )- جيهان مصطفى كمال البيطار ،اخلاقيات الاعلان ومدى تطبيقها من و اقع الممارسة الاعلانية

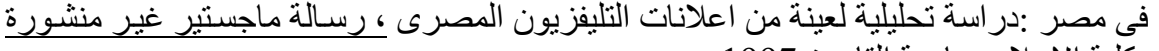

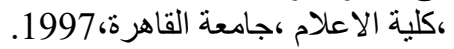

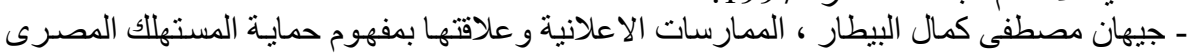

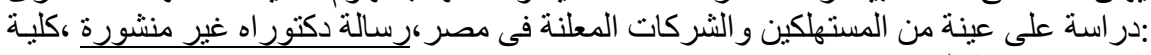

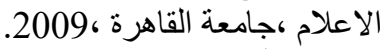

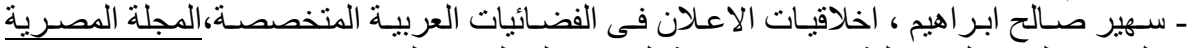

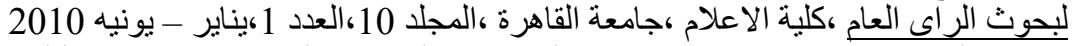

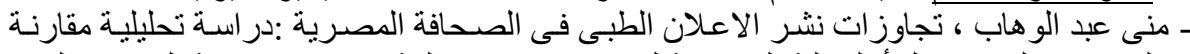

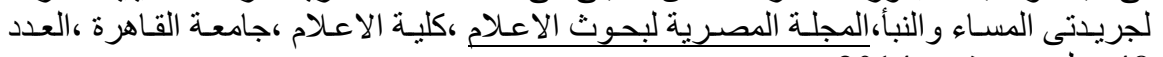

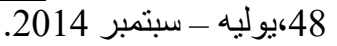

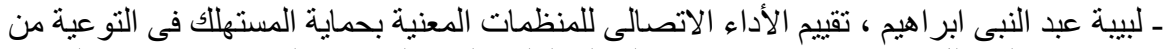

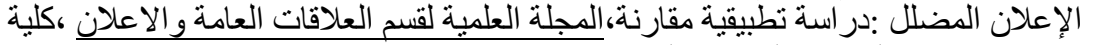

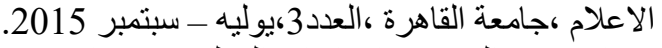

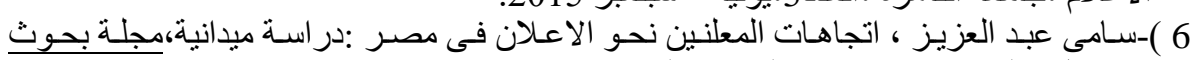

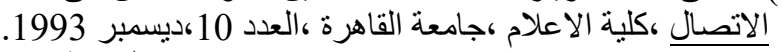

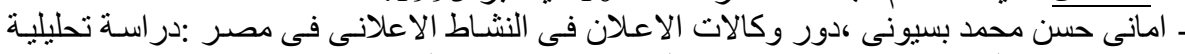

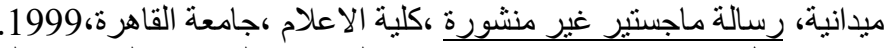

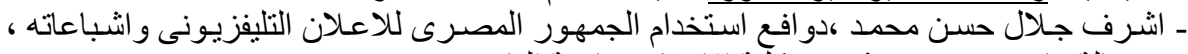

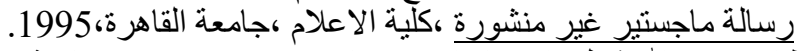

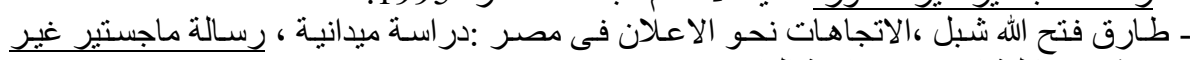

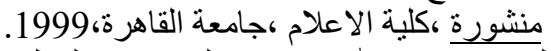

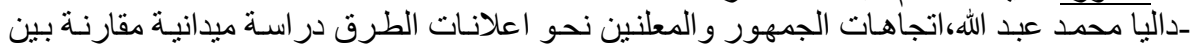

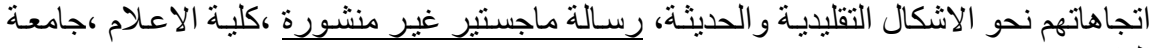

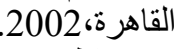

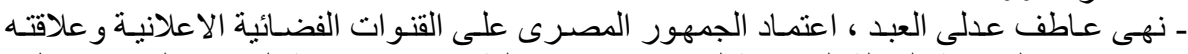

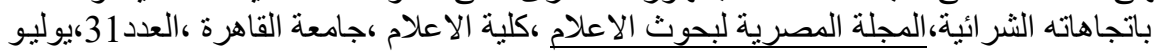
- سبتمبر - 2008. ـ سماح محمدى ،قارئية الاعلان الصحفى فى مصر :در استة ميدانية على عينة من قر اء الصحف

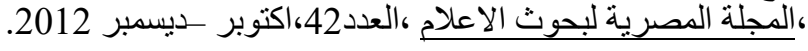


بحوث العلاقات العامة والاعلان فى مصر :الواقع واتجاهات المستقبل

ـ داليا ابر اهيم المتبولى ، اتجاهات طالبات الجامعة نحو الإعلان التليفزيوني: دراسة مقارنة على

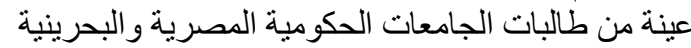
، المجلة العلمية لقسم العلاقات العامة والاعلان ،كلية الاعلام ،جامعة القاهرة ،العدد3،يوليه - سبتمبر 2015

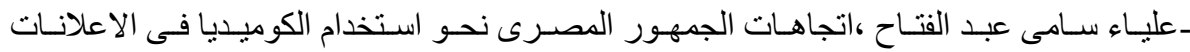

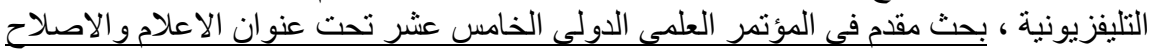

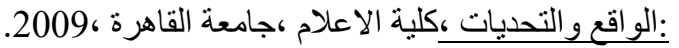

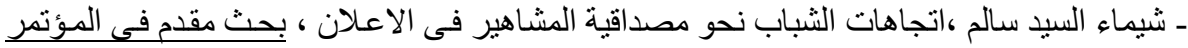

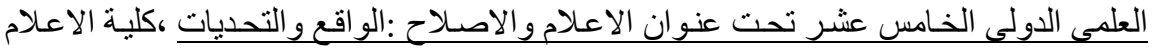

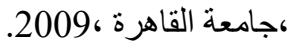

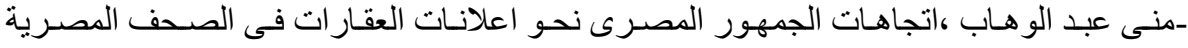

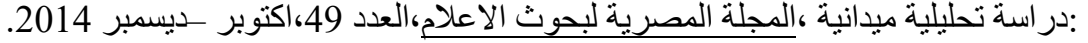

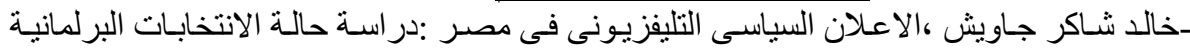

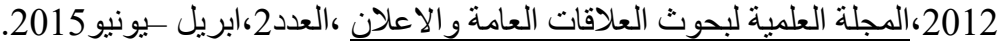

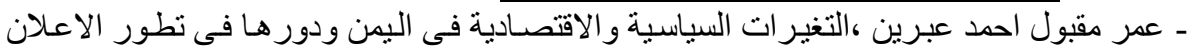

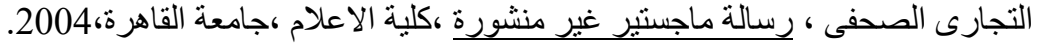

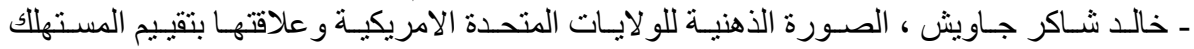

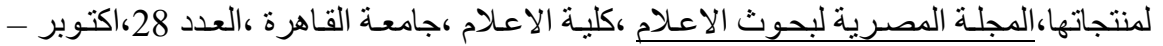
ديسمبر 2007.

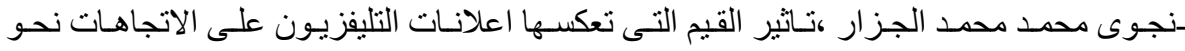

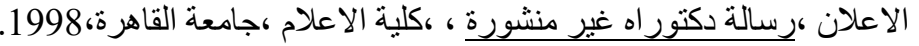

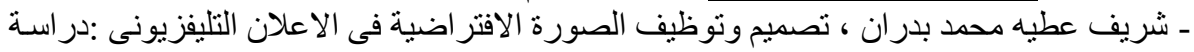

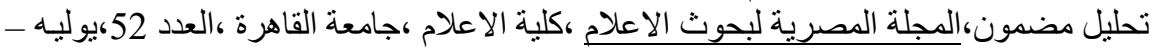
سبتمبر 2015. ـ مبرفت السيد احمد سليمان ،دور عناصر الرسالة الاعلانيـة فى فاعلية الاعلان الصحفى :دراسـة

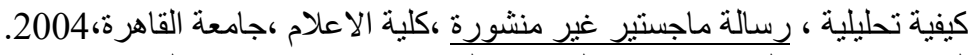

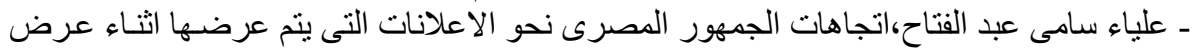

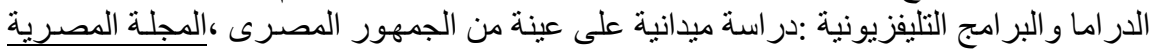

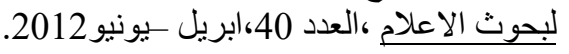

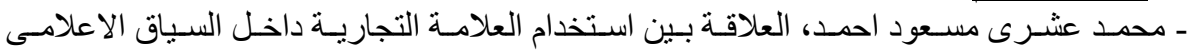

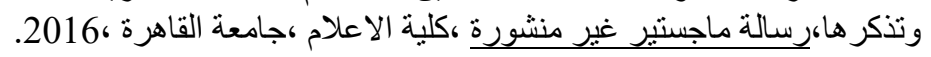

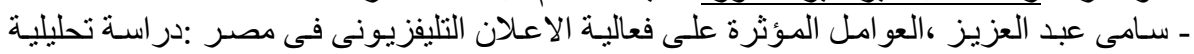

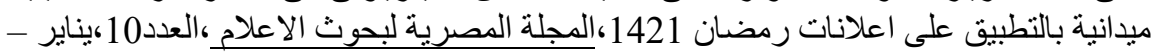

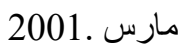

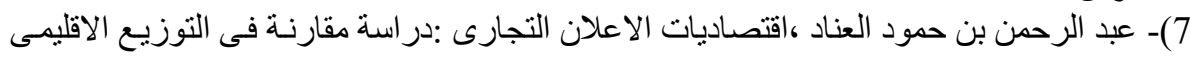

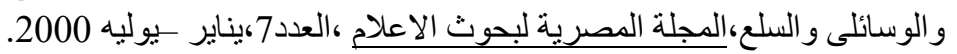

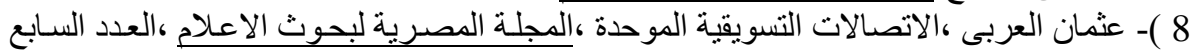
.2000، 


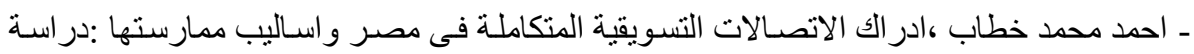
تطبيقية على عينة من الثركات ووكالات الاتهيلات الاعلان ،رسـالة ماجستير غير منشورة ،كلية الاعلام

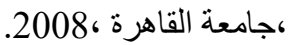

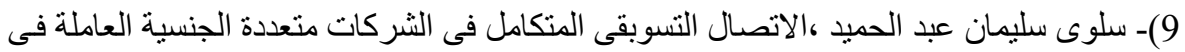

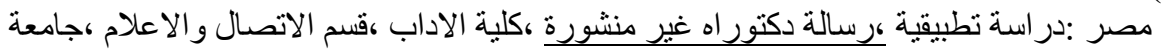

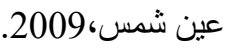
ـ سحر محمود حسن عبد الله ،استخدام الانترنت كأداة لتفعيل الاتصالات التسويقية المتكاملة بالتطبيق على الثركات السياحية فى مصر ،رسـالة ماجستير غير منشورة ،كلية التجارة ،جامعة القاهرة .2010،

- ايناس عبد الحميد الخريبى ،الاتصالات التسويقية المتكاملة المستخدمة فى تسويق الخدمات التعليمية

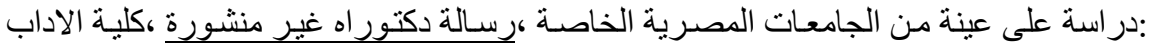
قسم الاعلام ،جامعة حلو ان ، 2011.

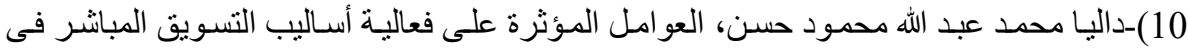

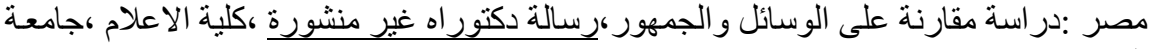

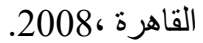

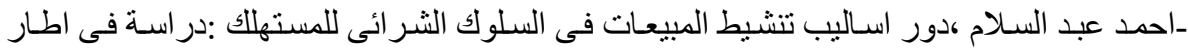

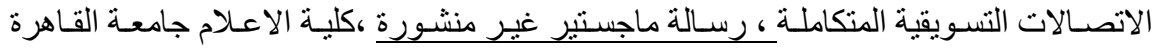

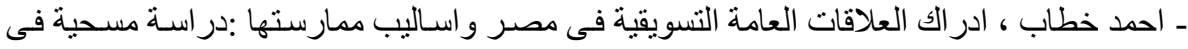

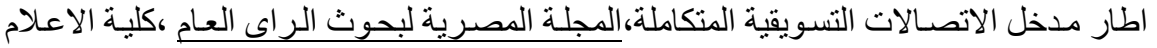

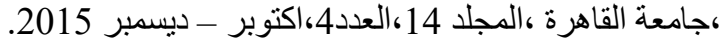
ـ ابر اهيم احمد السعيد، استخدام المرشحين لحملات العلاقات العات العامة فى اقناع الناخبين :در اسة ميدانية العانية

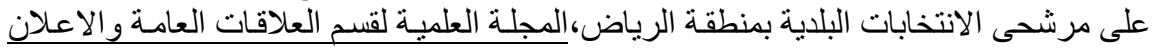

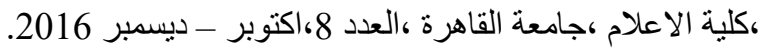

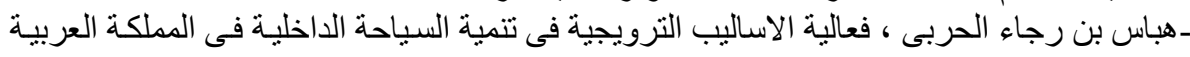

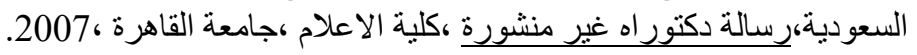

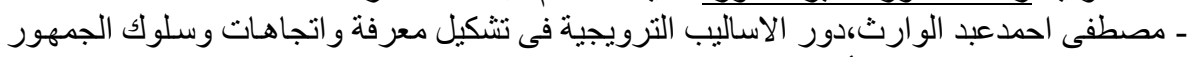

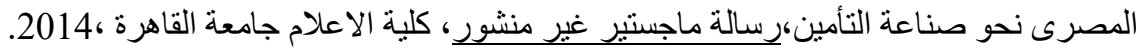

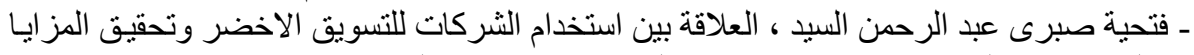

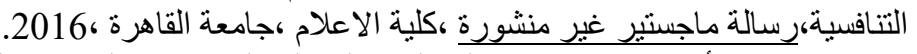

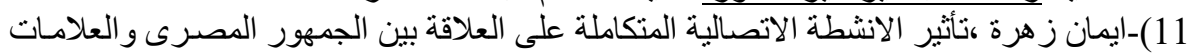

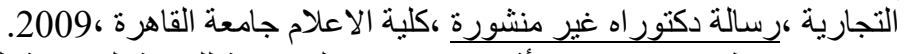

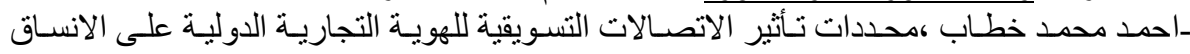

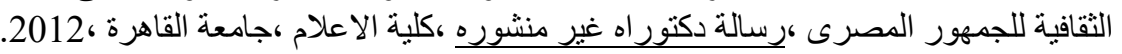

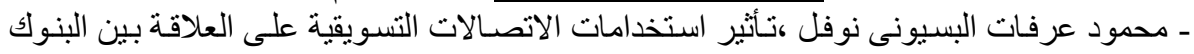

وجمهور ها:در اسة حالة ، رسالة ماجستير غير منشورة ،كلية الاعلام جامعة القاهرة ،2013. 


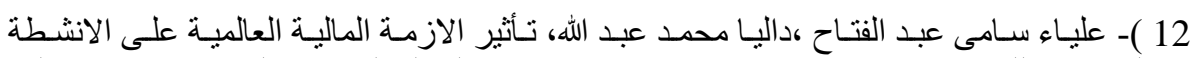

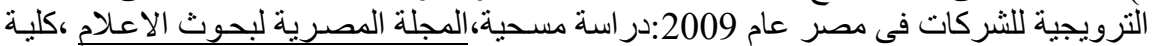

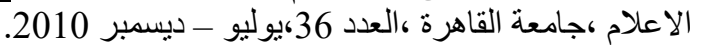

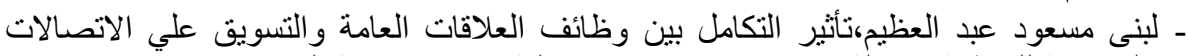

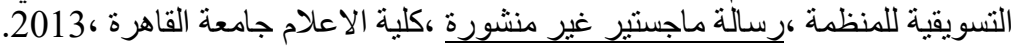

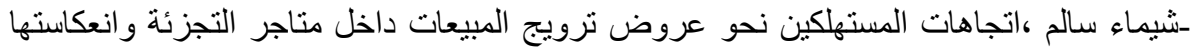

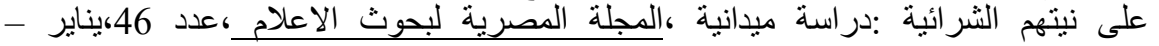

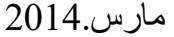

13)-نيفين احمد غبانـى ،دور قادة الراى في حمـلات التسويق الاجتمـاعى الموجـه للمر أة الريفيـة

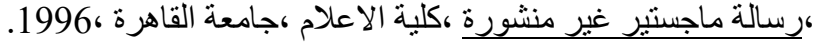

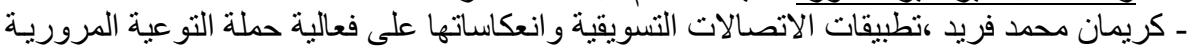

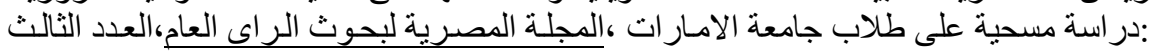
2000،

-بوران برهان الدين مريدن، تخطيط حملات التسويق الاجتماعى :بـالتطبيق على حملات الصحة العامة،رسالة دكتور اه غير منشورة ،كلية الاعلام ،جامعة القان القاهرة ،

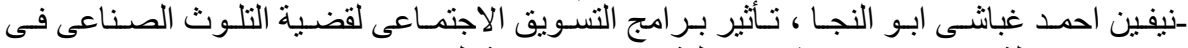

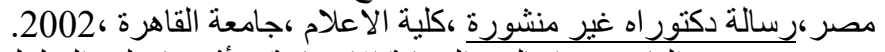

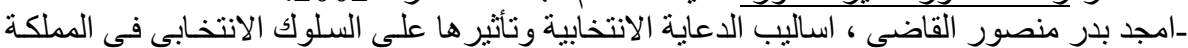

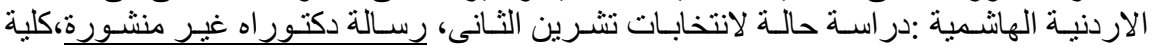
الاعلام ،جامعة القاهرة ، 2002.

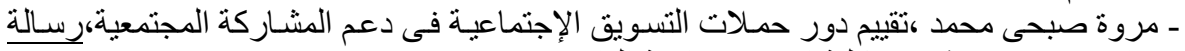
ماجستير غير منشورة ،كلية الاعلام،جامعة القاهرة ،2008.

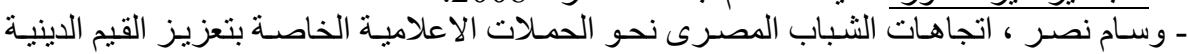

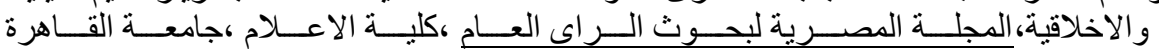

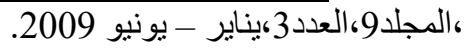

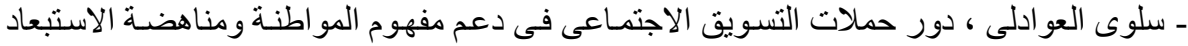

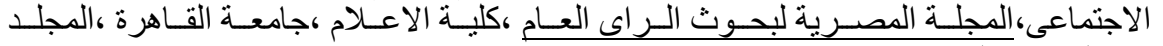
10،العدد2،يوليو - ديسمبر اليدير 2010

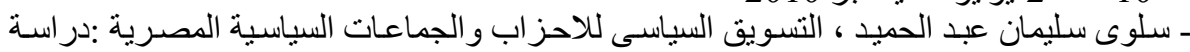

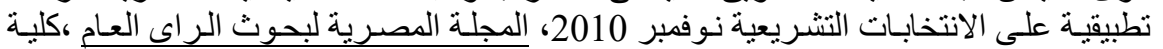

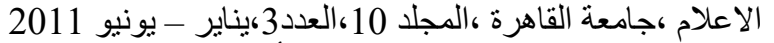

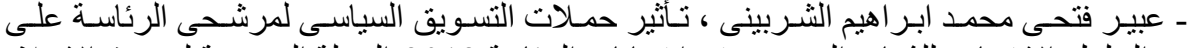

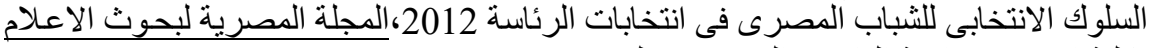

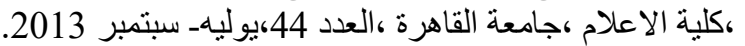

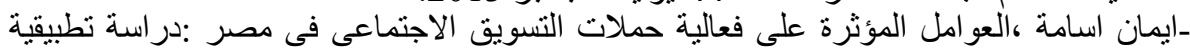

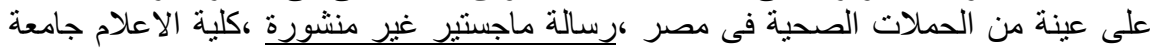

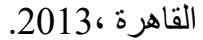

ـخالد النامى ،دور حملات التسويق الاجتماعى فى دعم التغيير فى المملكة العربية السعودية :دراسة تطبيقية على حملات الحوار الوطنى ،رسالة دكتور راه غير منشورة ،كلية الاعلام ،جامعة القاهرة .2014، 
ـمروة حنفى ،دور الاتصالات التسويقية فى دعم اساليب الترويج السياحى لمصر فى الداخل :دراسة

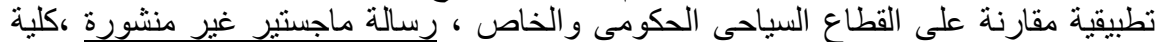

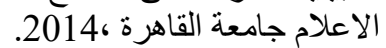

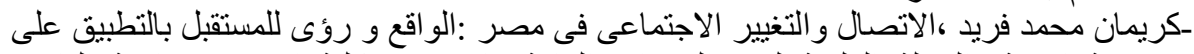
قضية الامية ،المجلة العلمية لقسم العلاقات العامة والعيد والاعلان ،كلية الاعلام ،جامعة القاهرة

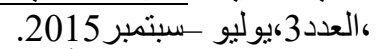

- ياسر بن على الثهرى، أنشطة الترويج في حملات التوعية الاجنماعية والعوامل المؤثرة في في التئي

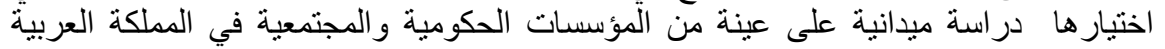

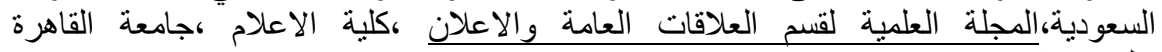

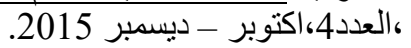

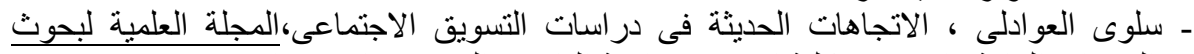

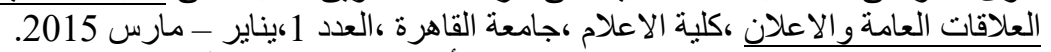
ـ مروة مصطفى مصطفى شميس ، الاتجاهات الأساسية في نظرية التسوية الإيق الاجتماعي دراسة الإنة استطلاعية، المجلة العلمية لقسم العلاقات العامة والاعلاني ،كلية الاعلام ،جامعة القاهرة

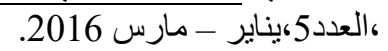

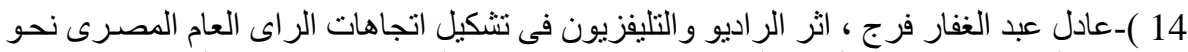

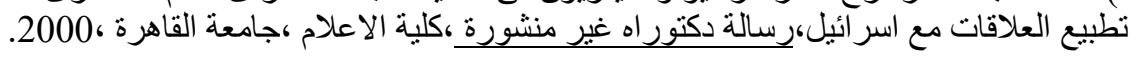

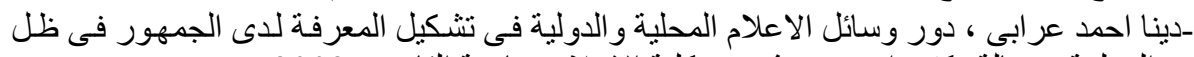

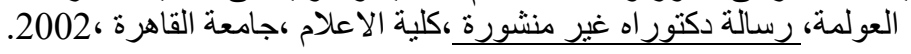

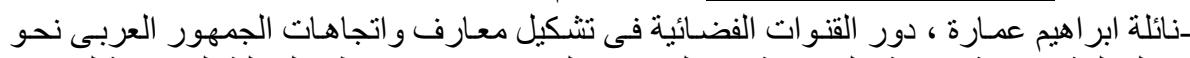

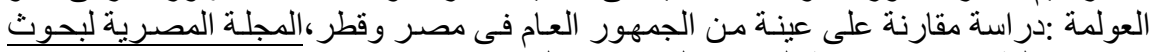

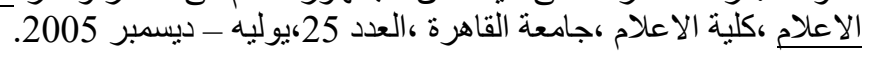

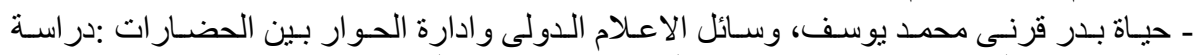

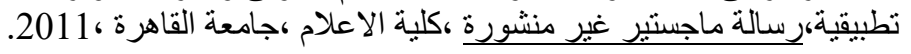

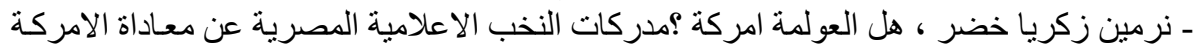

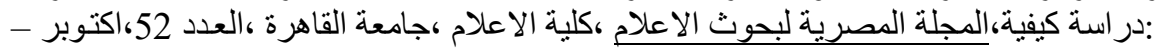
ديسمبر 2015.

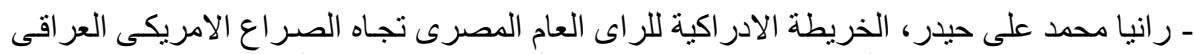

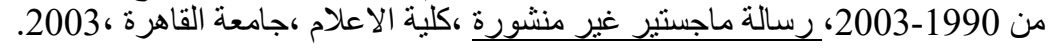

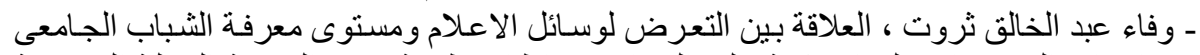

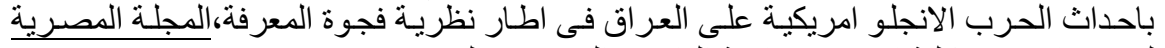

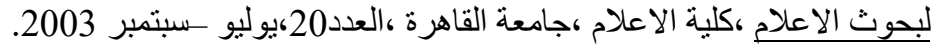

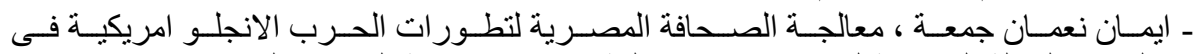
العراق،المجلة المصرية لبحوث الاعلام ،كلية الاعلام ،جامعة القاهرة ،العدد222،يناير - يونيـه .2004

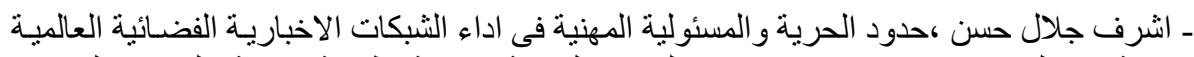

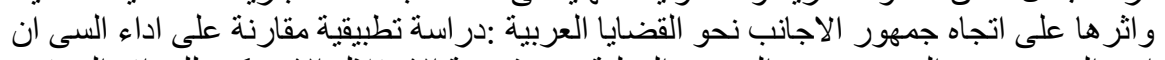

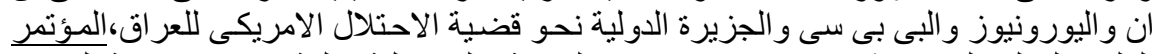

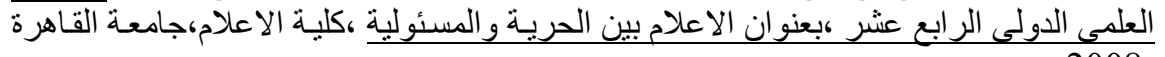
.2008، 
بحوث العلاقات العامة والاعلان فى مصر :الواقع واتجاهات المستقبل

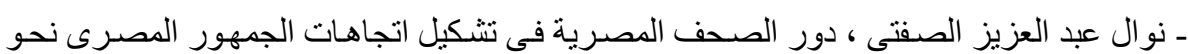

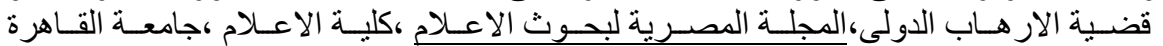

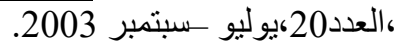

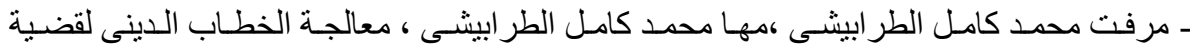

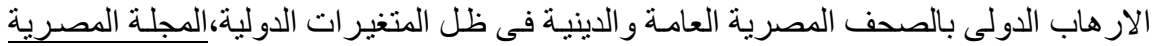

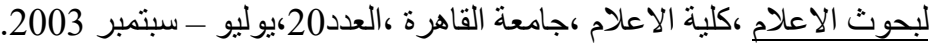

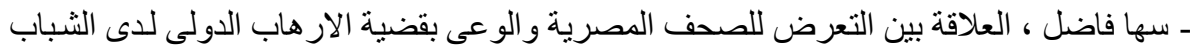

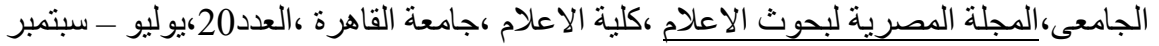

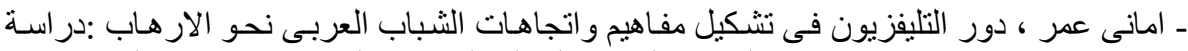

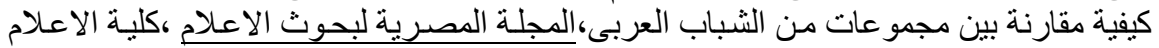

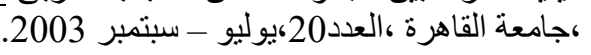

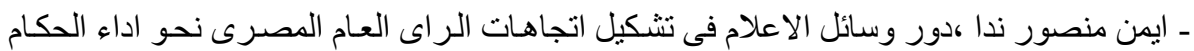

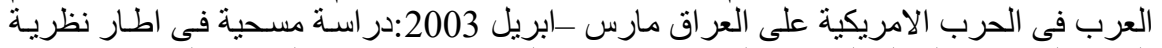

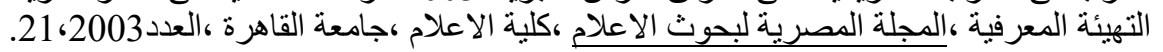

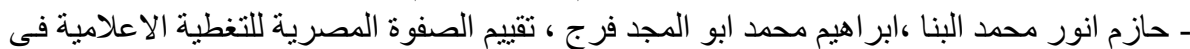

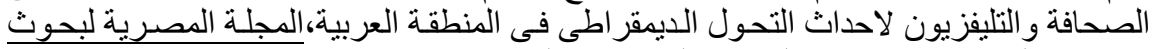

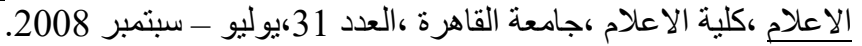

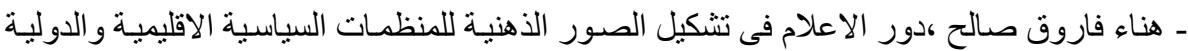

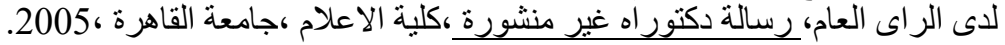

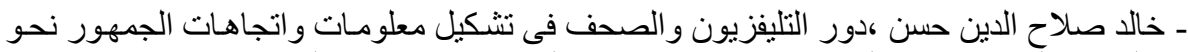

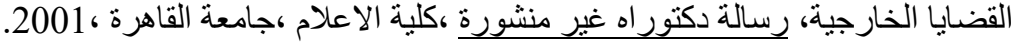

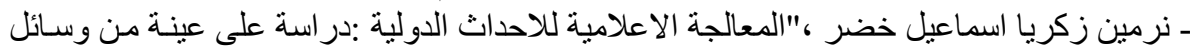

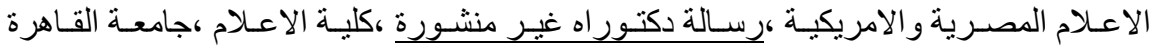
.2006،

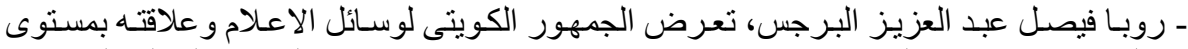

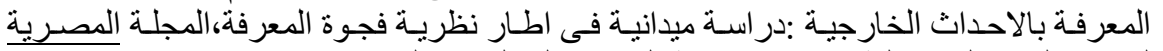

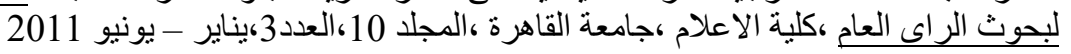

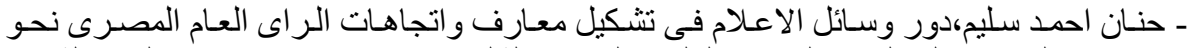

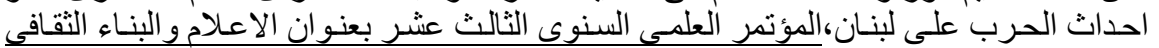

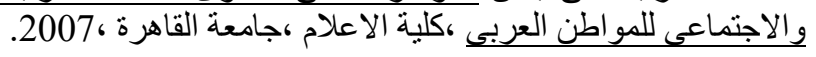

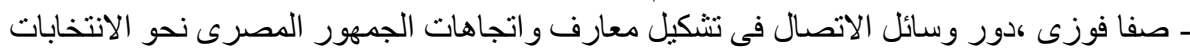

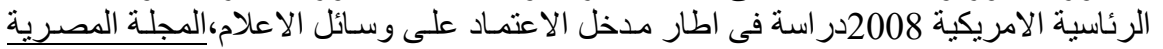

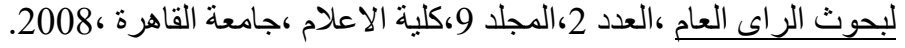

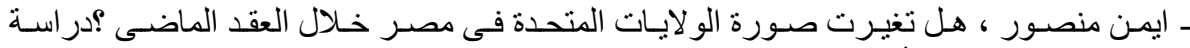

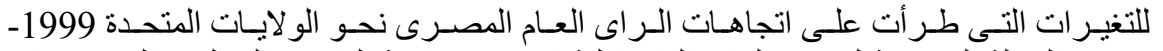
2008، المجلة المصرية لبحوث الر اي العام ،كلية الاعلام ،جامعة القاهرة ،المجلد 9،العدد3،يناير - يونيو 2009. 


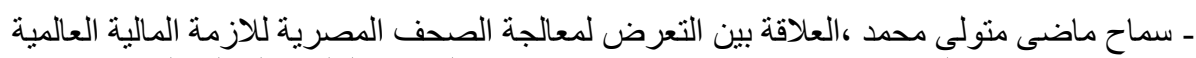

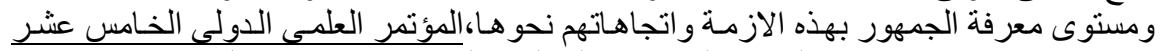

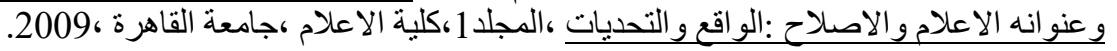

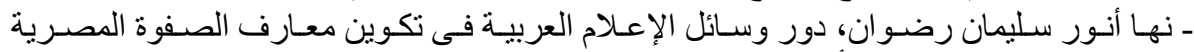

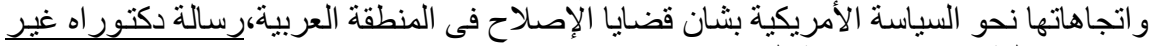

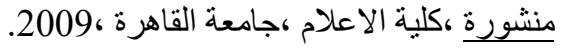

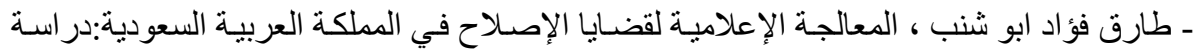

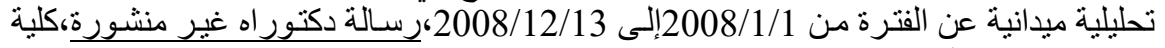

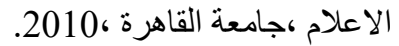

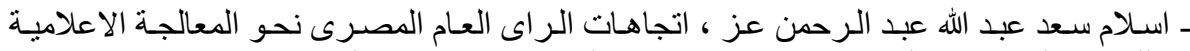

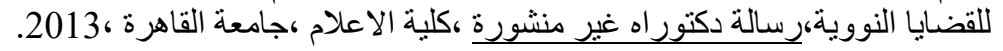

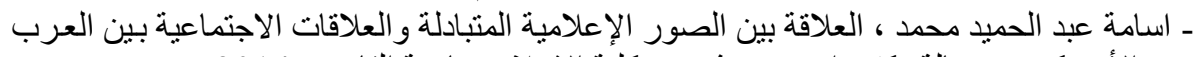

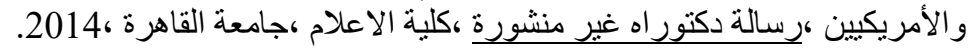

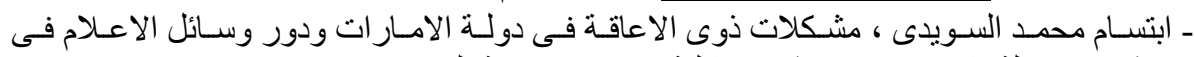

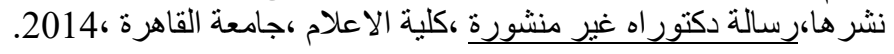

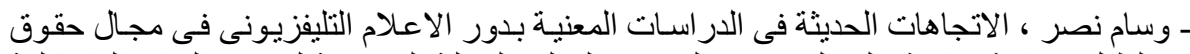

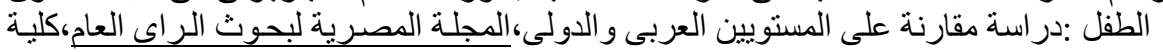

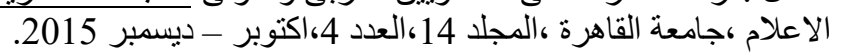

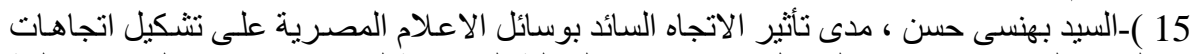

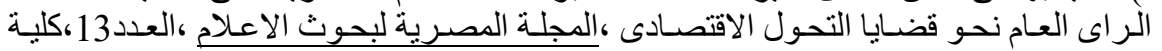

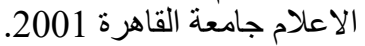

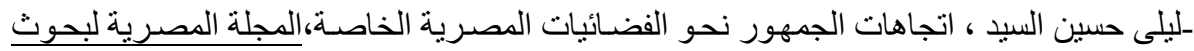

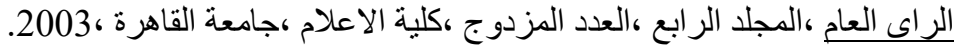

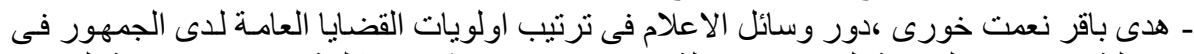

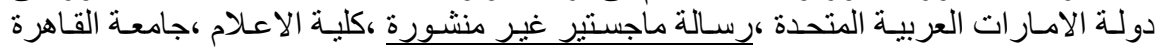
.2002،

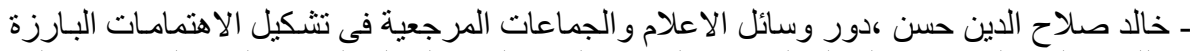

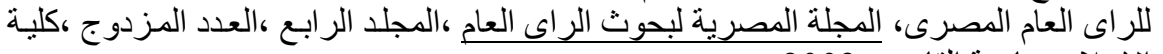

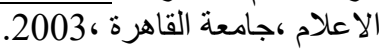

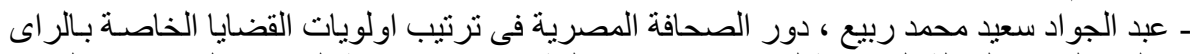

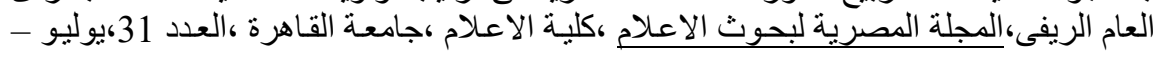

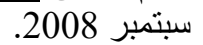

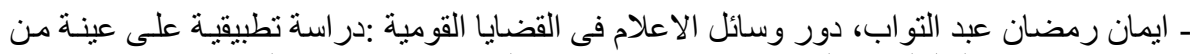

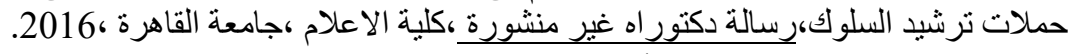

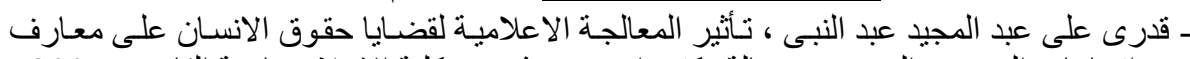

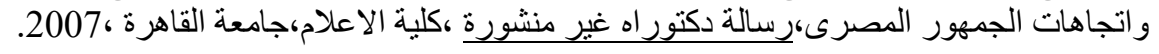

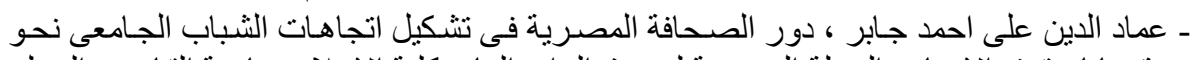
قضايا حقوق الانسان ،المجلة المصرية لبحوث الرئ الرئ العام ،كلية الاعلام ،جامعة القاهرة ،المجلد 10 ، العدد 1،يناير - يونيه 2010 
بحوث العلاقات العامة والاعلان فى مصر :الواقع واتجاهات المستقبل

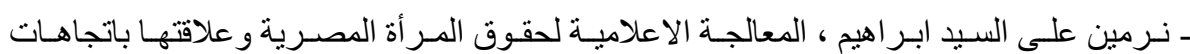

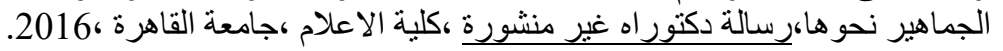

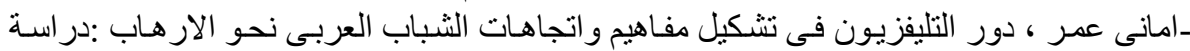

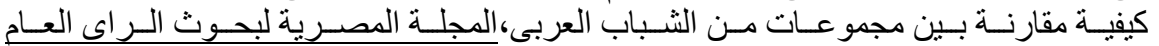

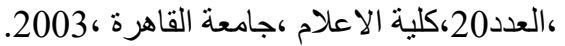

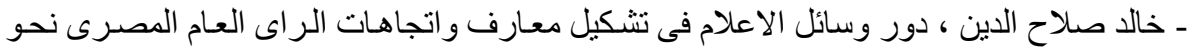

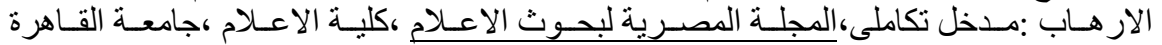
، العدد20،يوليو - سبتمبر 2003.

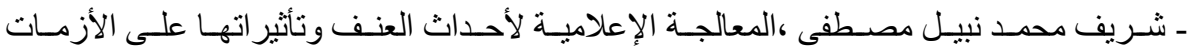
الاقتصادية بعد الثورة، رسالة ماجستير غير منشورة ،كلية الاعلام ،جامعة القاهرة ،

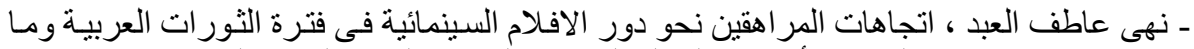

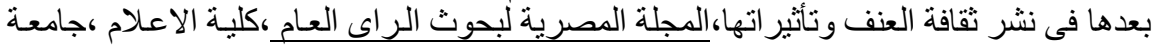

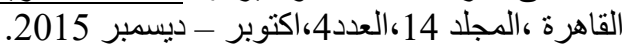

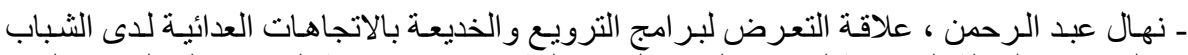

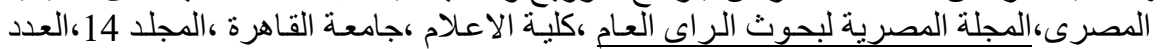

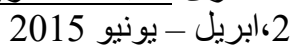

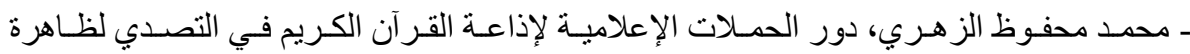

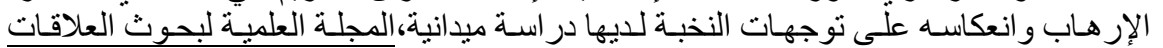

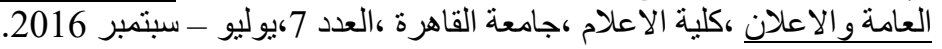

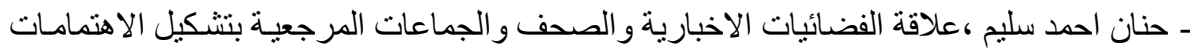

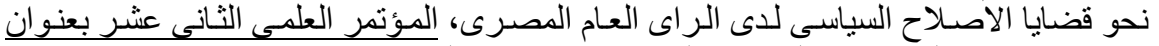

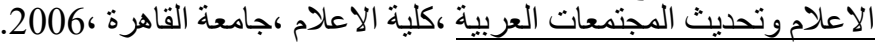

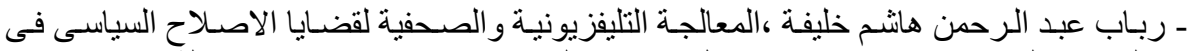

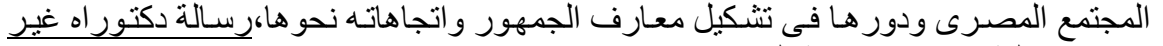

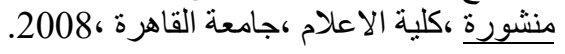

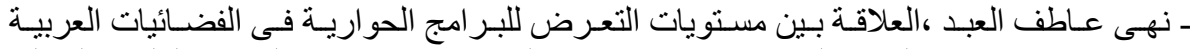

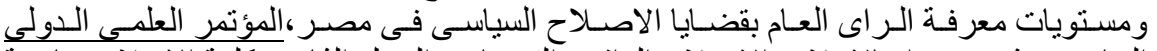

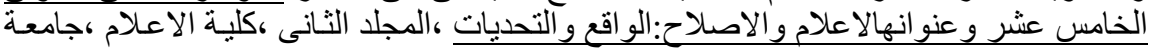

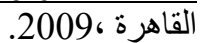

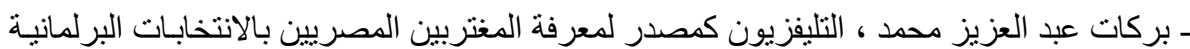

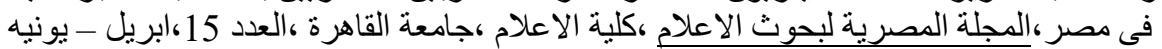
.2002

ـ اميمة محمد عمر ان ،موقف الصحفيين المصريين من تغطية وسائل الاعلام المصرية للانتخابـات

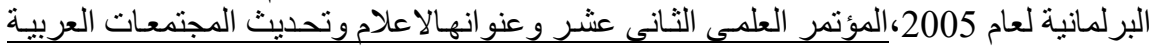

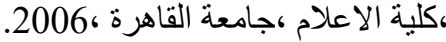

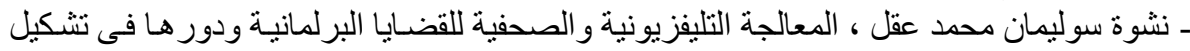

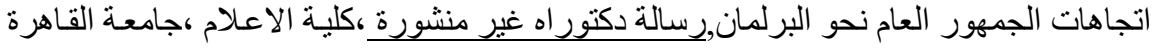
.2006، 


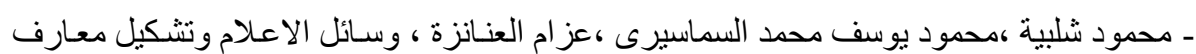

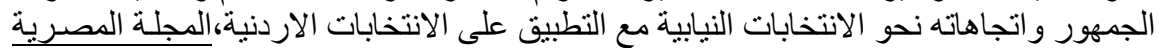

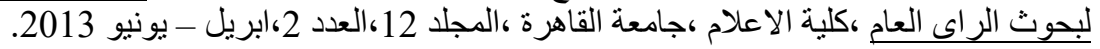

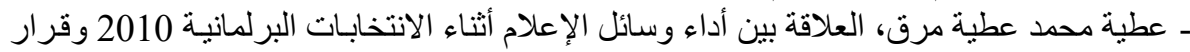

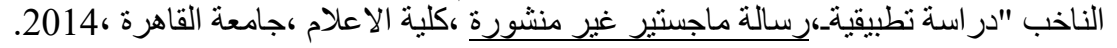

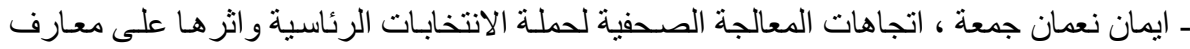

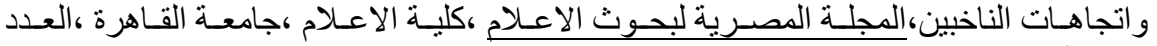

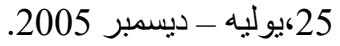

ـ نهى عاطف العبد ، اتجاهات الر ايى العام المصرى نحو التغطبة الاعلامية للانتخابات الرئاسية لسنة

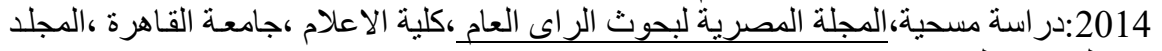

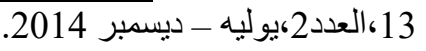

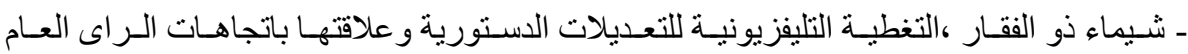

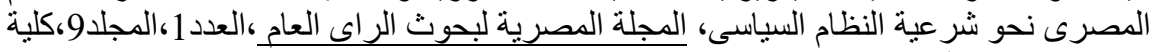
الاعلام ،جامعة القاهرة ، 2008.

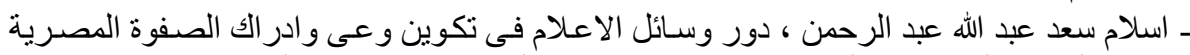

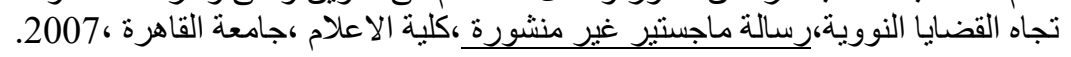

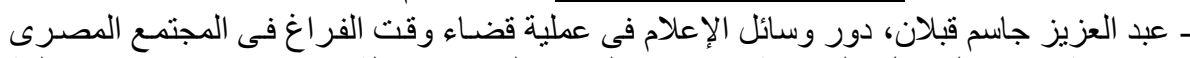

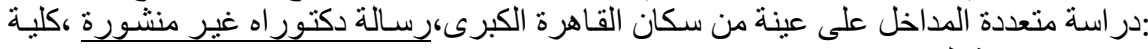

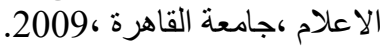

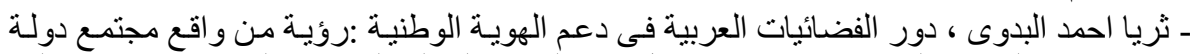

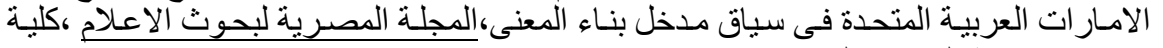

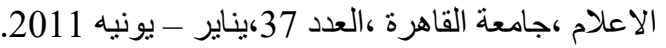

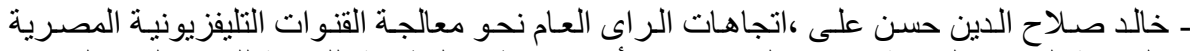

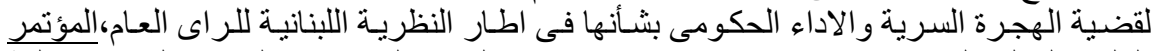

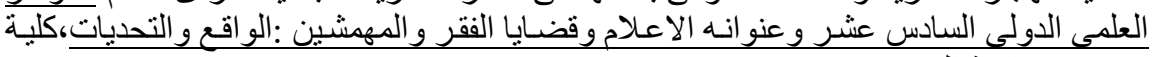

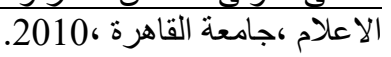

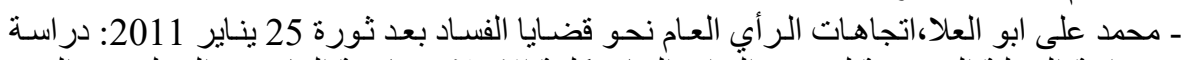

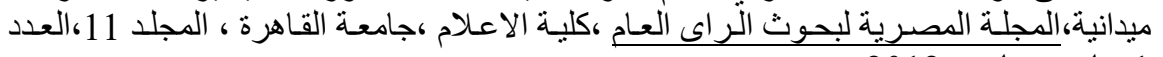

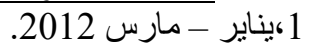

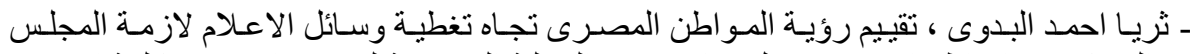

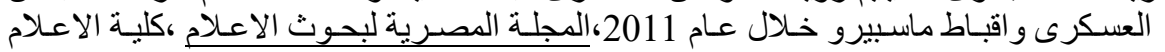
ـ جامعة القاهرة ،العدد 41،يوليو - سبتمبر 2012.

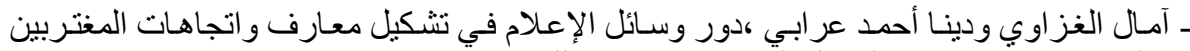

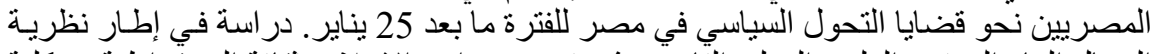
الاعجال العام،المؤتمر العلمى الدولى التاسع عثر تحت عنو التهان "الاعلام وثقافة الديمقر اطية " ،كلية

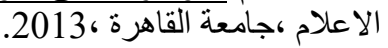

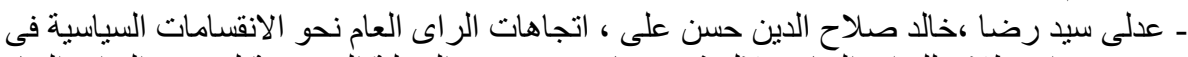

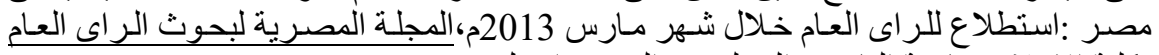
،كلية الاعلام ،جامعة القاهرة ،المجلد 12،العدد 2،ابريل - يونيو 2013. 
ـ محدد حسين المهان ،دور وسائل الإعلام في نشر الوعي الأمني لدى الجمهور الكويتي "دراسة

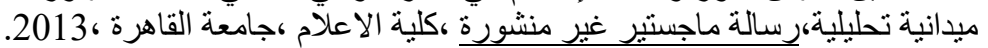

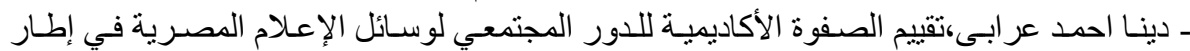

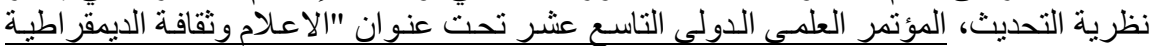

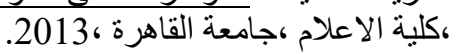

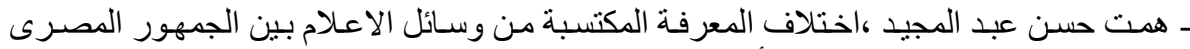

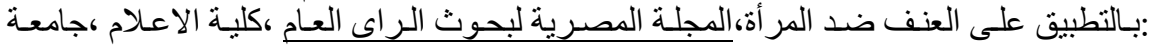

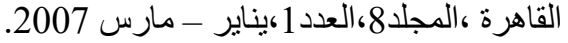

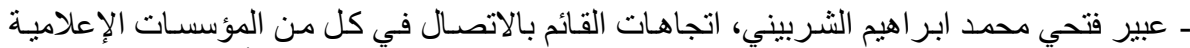

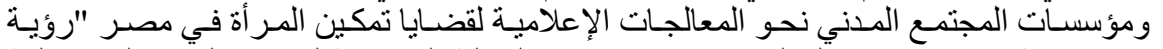

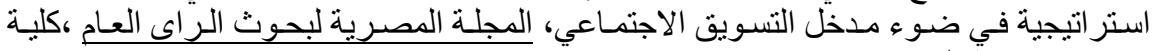

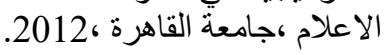

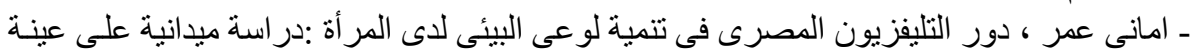

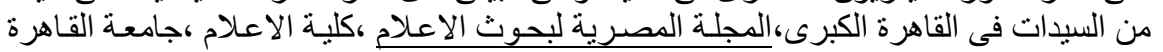

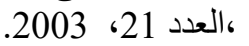

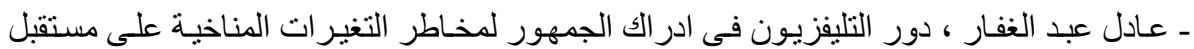

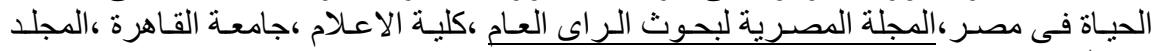

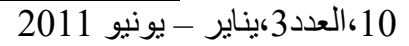

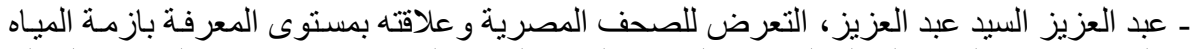

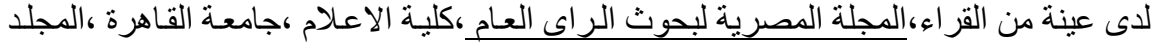

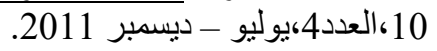

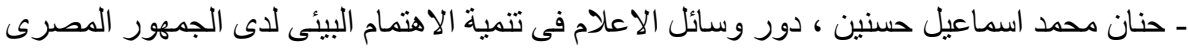

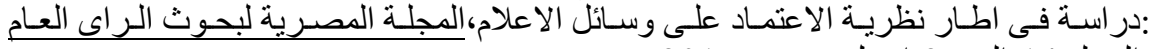

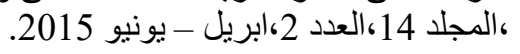

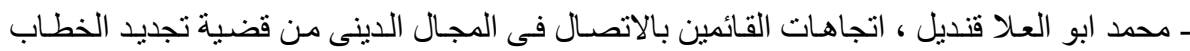
الدينى :در اسة الميدانية، المجلة المصرية لبحات البحوث الر ائى العام ،كلية الاعلام ،جامعة القاهرة ،المجلد

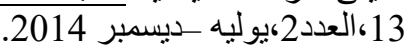

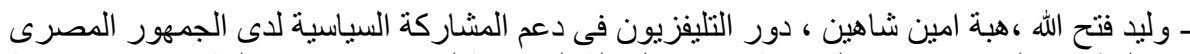

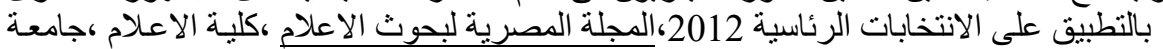

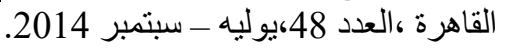

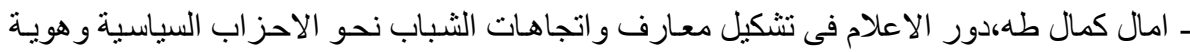

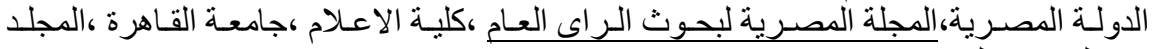

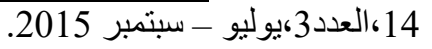

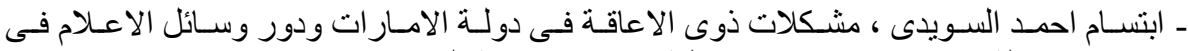

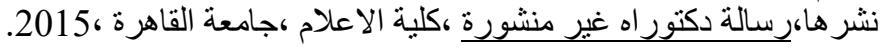

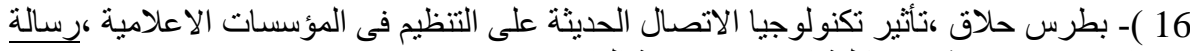

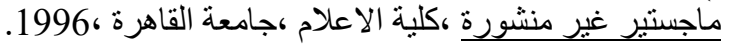

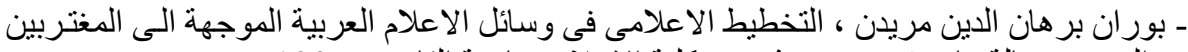
العرب،رسالة ماجستير غير منشورة ،كلية الاعلام ،جامعة القاهرة ،1997. 
بحوث العلاقات العامة والاعلان فى مصر :الواقع واتجاهات المستقبل

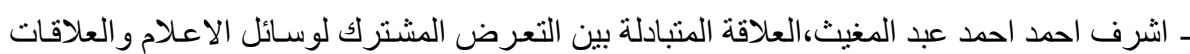

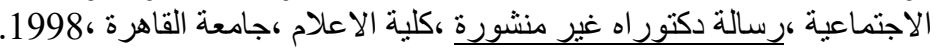

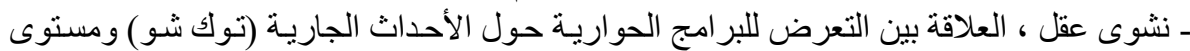

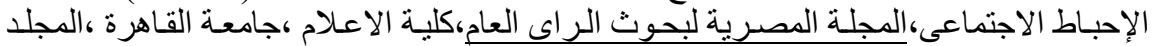

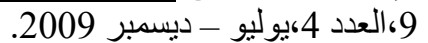

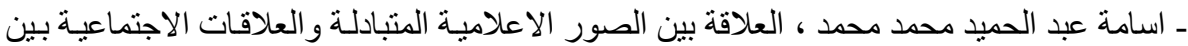
العرب و الامريكيين :در اسة مسحية، رسالة دكتور اه غير منشورة ،كلية الاعلام ،جامعة القاهرة الإنة .2014،

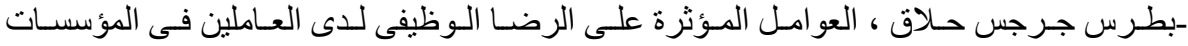

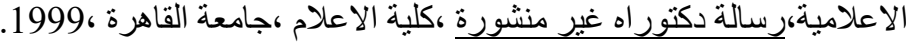

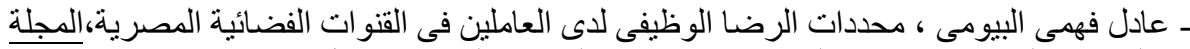

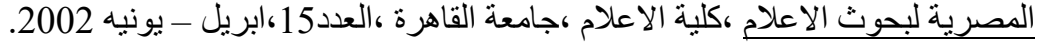

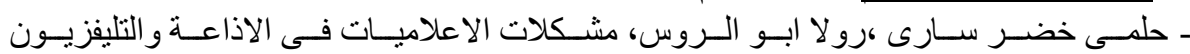
الاردنى،المجلة المصرية لبحوث الاعلام ،كلية الاعلام ،جامعة القاهرة ،العدد 29،يناير - مارس لارس

ـ ايناس ابو يوسف ، اتجاهات الاعلاميين المصريين نحو اعـادة هيكلة اعلام الدولة بعد ثورة 200

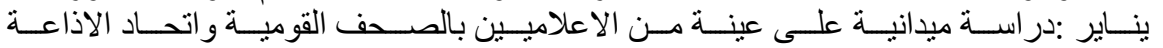
و التليفزيون،المجلة المصرية لبحوث الراي العام ،كلية الاعلام ،جامعة القاهرة ،المجلد 11، 1العدد العداد

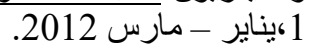

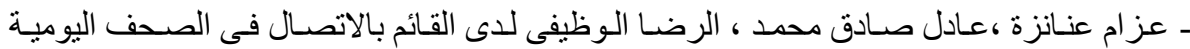

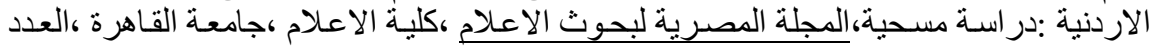

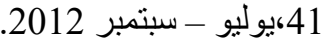

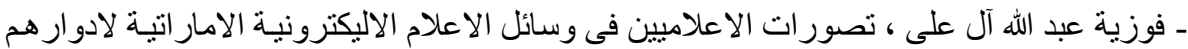

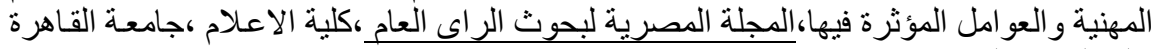

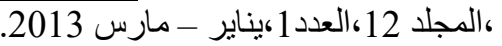

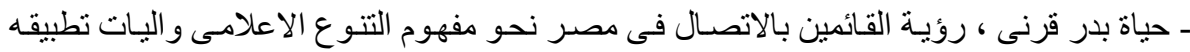

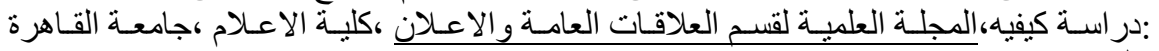

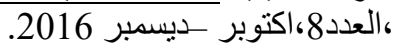

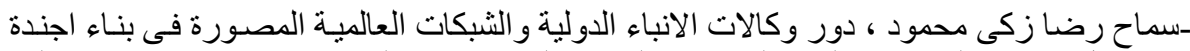

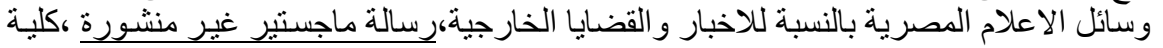

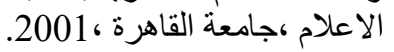

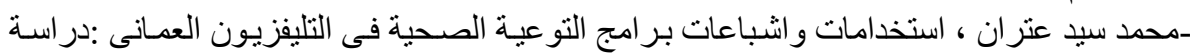
تحليلية وميدانية، المجلة المصرية لبحوث الاعلام ،كلية الاعلام ،جامعة القاهرة ،العدد 23،يوليه لئه ديسمبر 2004. ـ عبدالعزيز محمد العيد ، استخدامات الجمهور في مملكة البحرين لوسيائل الاعـلام والاشـباعات المتحققة منها،رسالة ماجستير غير منشورة ،كلية الاعلام ،جامعة القاهرة ،2005.

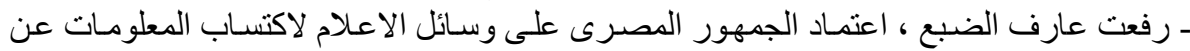

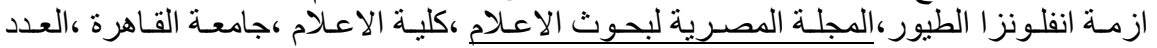

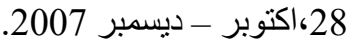


ـ محمود حسن اسماعيل ،ناصر محمود عبد الفتاح ، استخدامات الاطفال سـاكنى احو اش المات المقابر

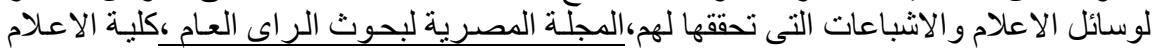

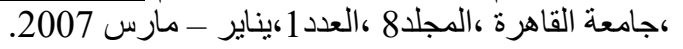

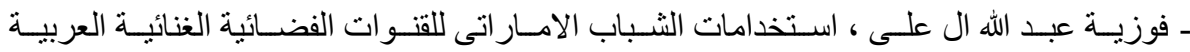

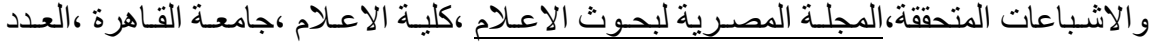

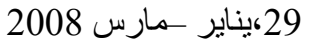

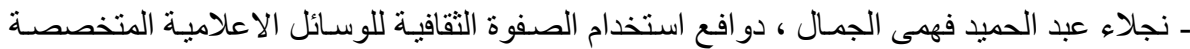

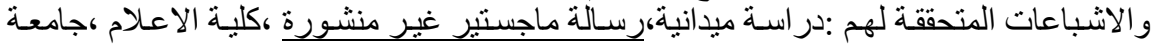

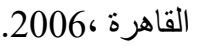

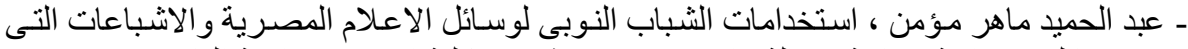

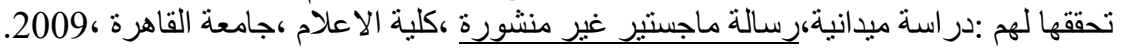

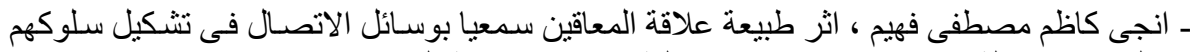

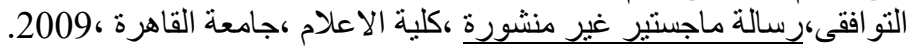

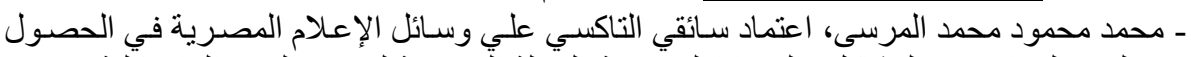

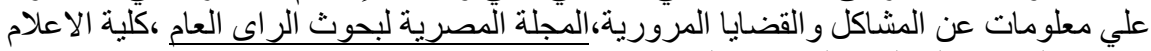

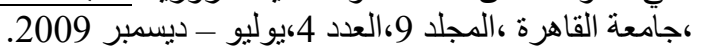

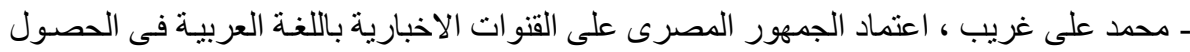

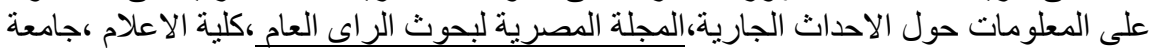

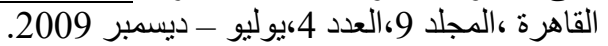

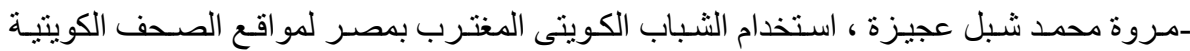

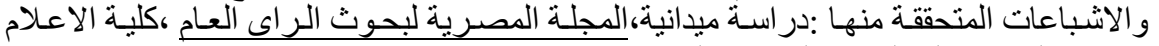

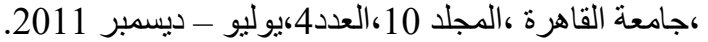

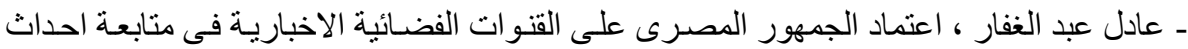

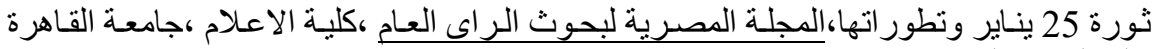

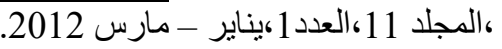

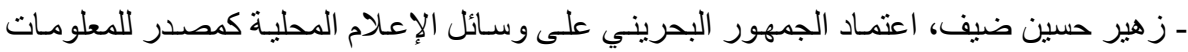

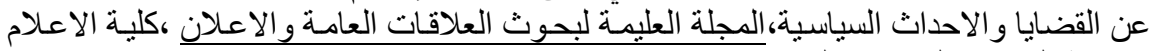

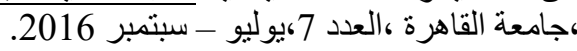

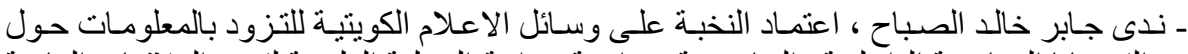

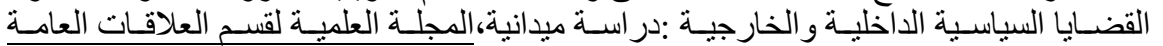

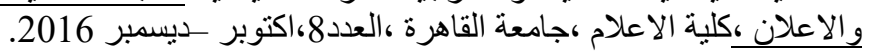

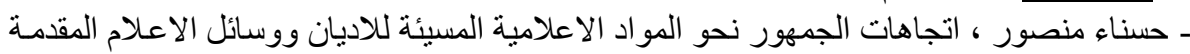

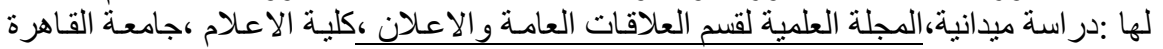

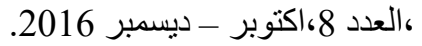

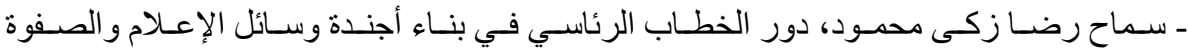

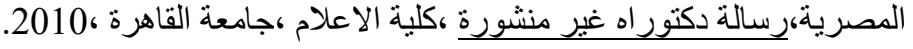

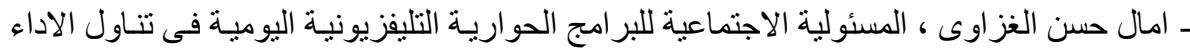

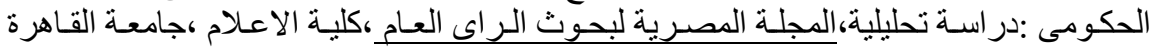

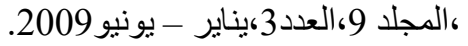


-إيمان محمد سليمان، معايير الحكم الرشيد لاى وسائل الاعلام المصرية: دراسـة تطبيقية على عينة

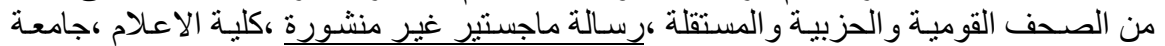

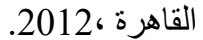

ـ ثريا أحمد البدوي ،المسئولية الإجتماعية لوسائل الإعلام كأحد معايير الحوكمة الإعلامية فى مصر :

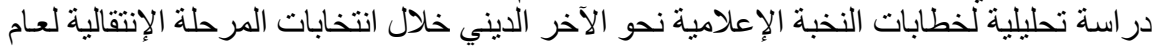

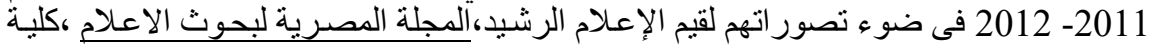

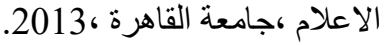

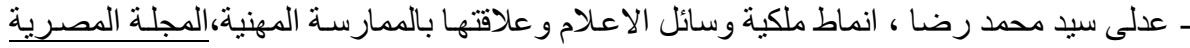

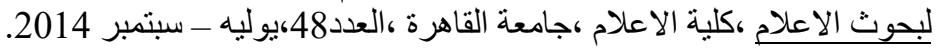

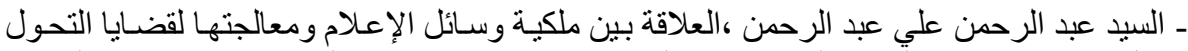

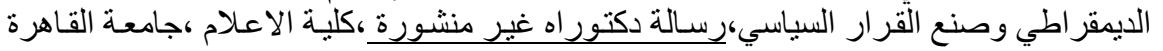
.2015،

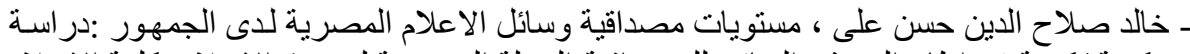

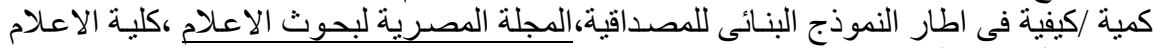

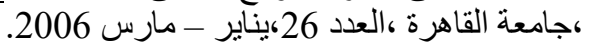

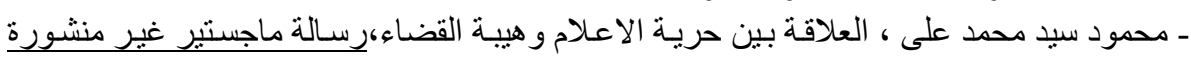
كلية الاعلام ،جامعة القاهرة ،2015.

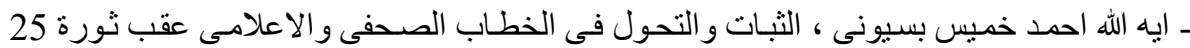

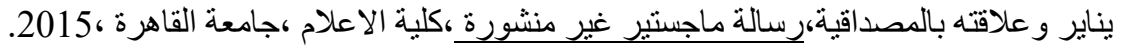

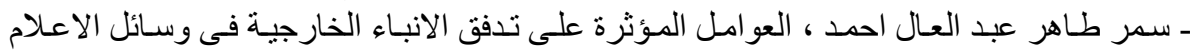

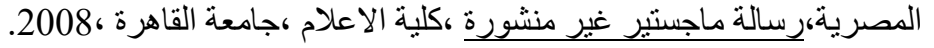

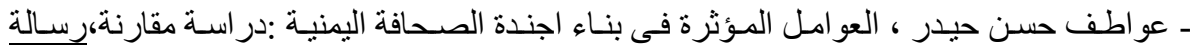
ماجستير غير منشورة ،كلبة الاعلام ،جامعة القاهرة ،

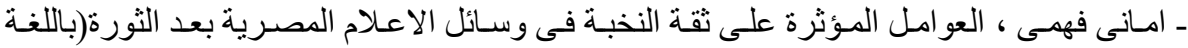

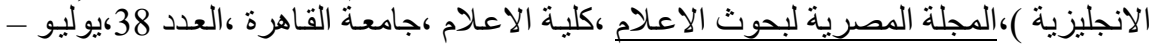
ديسمبر 2011.

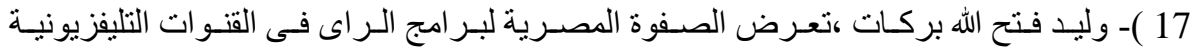

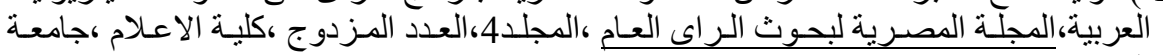

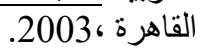

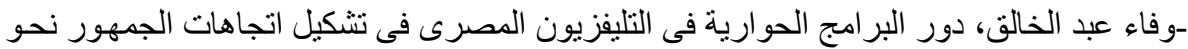

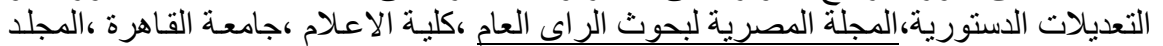

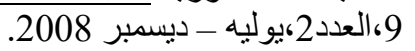

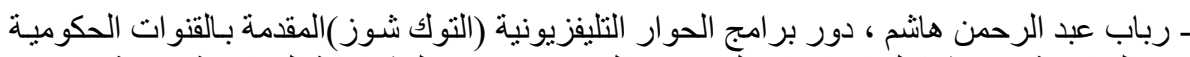

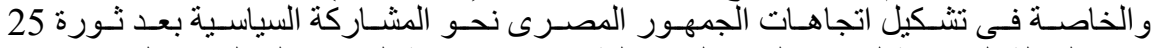

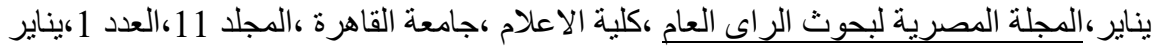

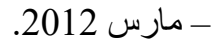

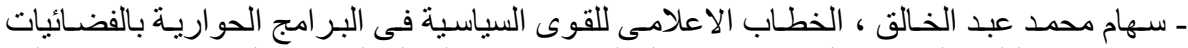

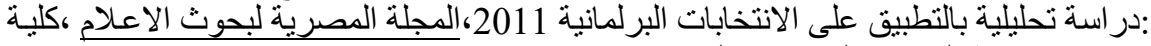
الاعلام ،جامعة القاهرة ،العدد48،يوليه - سبتمبر الانيات اليرلية 2014. 
ـ شيماء ذو الفقار ، العلاقة بين التعرض للبرامج الحوارية فى التليفزيون و الهوية الثقافية لدى الثباب

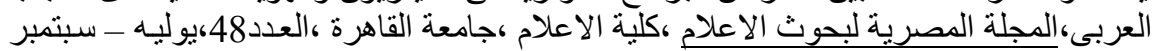
2014

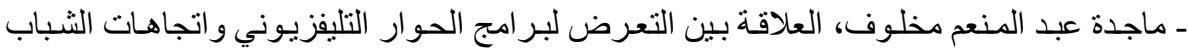

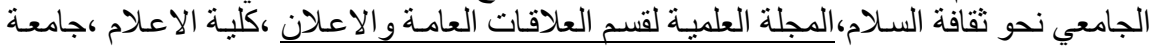

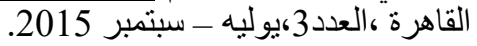

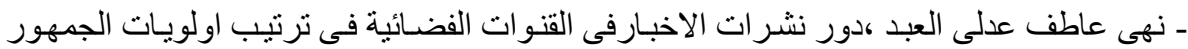

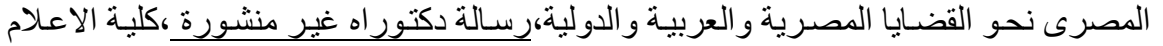

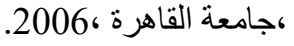

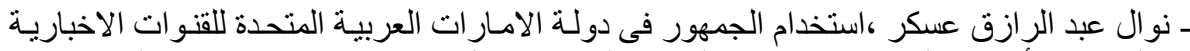

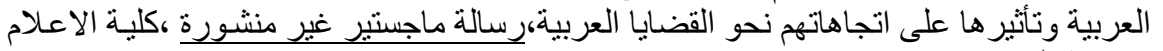

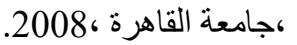

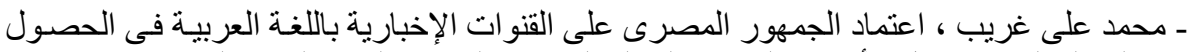

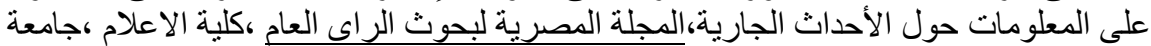

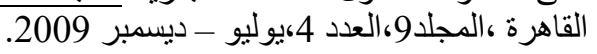

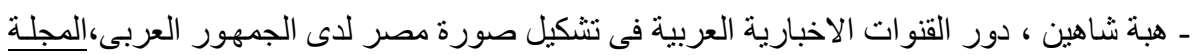

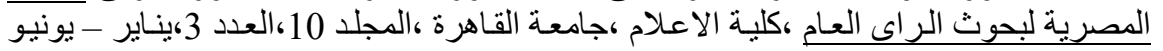
2011

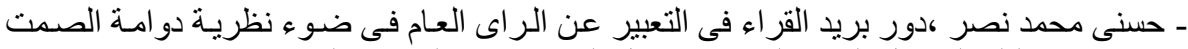

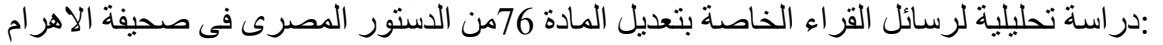

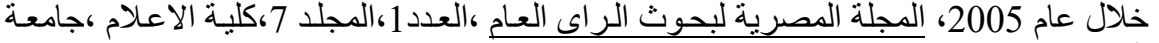

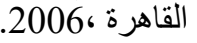

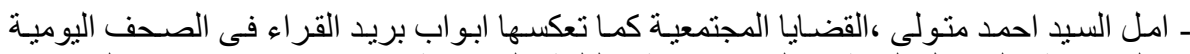

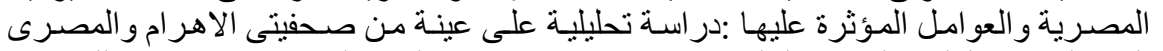

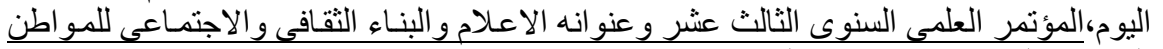
ـ العربي ،كلية الاعلام ،جامعة القاهرة ،

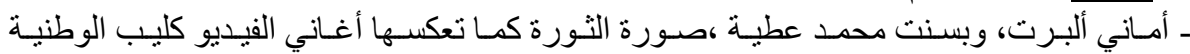

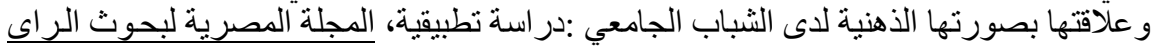
العام ،كلية الاعلام ،جامعة القاهرة ،

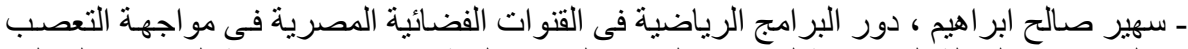

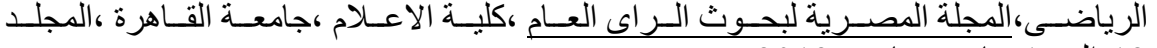

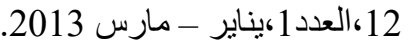

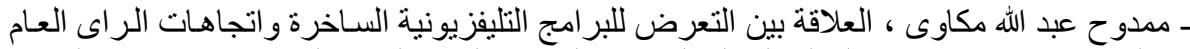

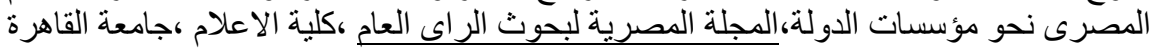

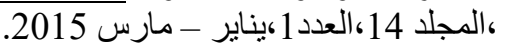
18 )-حنان فاروق محمد جنيد ، دور الاتصال في انتشـار المستحدثات :دراسـة تطبيقية على انتشـار

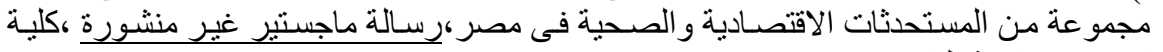
الاعلام ،جامعة القاهرة ، 1990. 


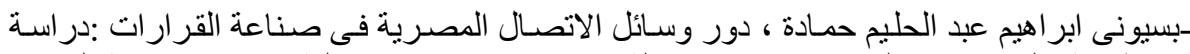
نطبيقية على صانعى القرار فى مصر، برسالة دكتور اهن غير منشورة ،كلية الاعلام ،جامعة القاهرة .1991،

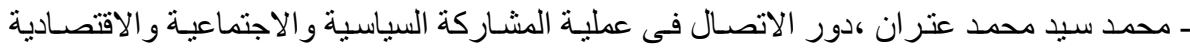
:در اسة تطبيقية مقارنة على قريتين مصريتين ،رسالة دكتور اه غير منشورة ،كلية الاعلام ،جامعة الأية

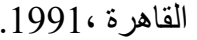

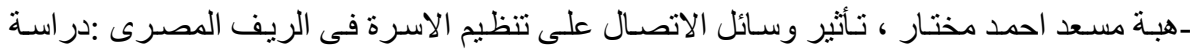
ميدانية مقارنة على قريتين مصريتين،رسير اللة ماجستير غير منشورة ،كلية الاعلام ،جامعة القاهرة

.1991،

-خيرت معوض محمد عياد ،دور الاتصلال فى التنمية السياسية :در اسـة ميدانية مقارنـة على قريتين

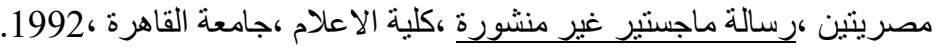

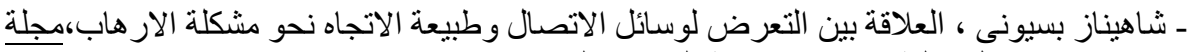

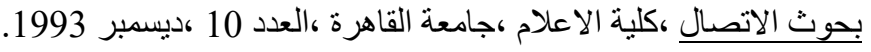

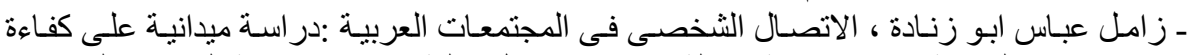

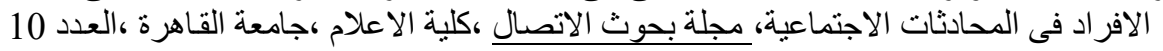

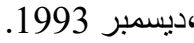
ـ ايمـان رمضـان عبد التواب ، دور الاتصـال فى تتميـة المجتمعـات المحلية،رسـالة ماجستير غير منشورة ،كلية الاعلام ،جامعة القاهرة ،

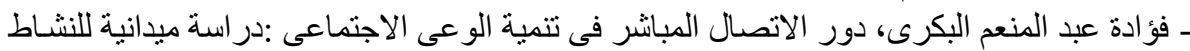

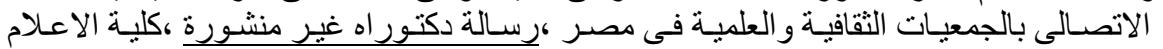

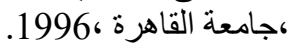

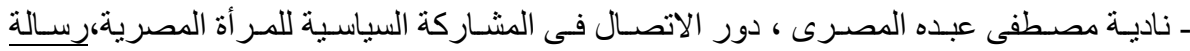

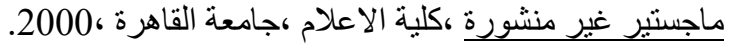

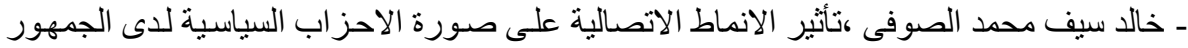

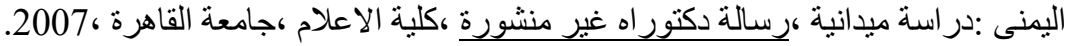

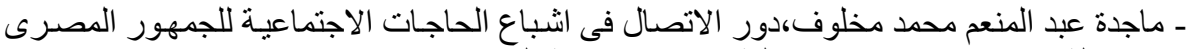

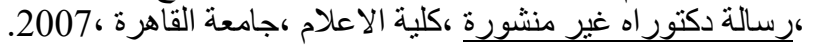

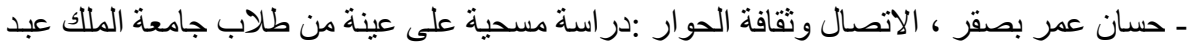
العزيز بجدة، المجلة المصرية لبحوث الاعلام ،كلية الاعلام ،جامعة القاهرة ،العدد 29 29،يناير -

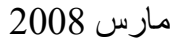

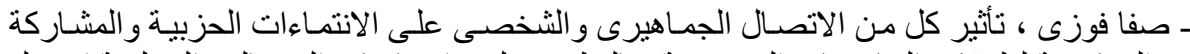

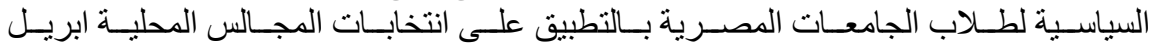

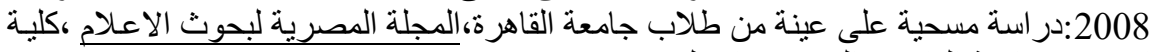

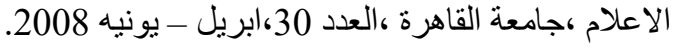

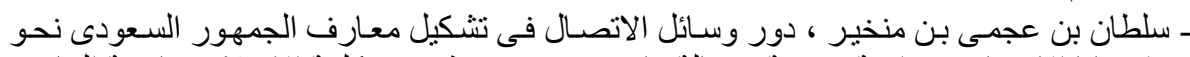

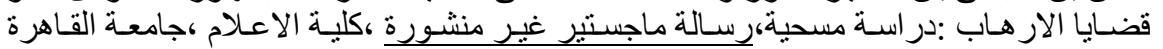
2008،

ـ صفا فوزى، دور وسائل الاتصال فى تشكيل معارف واتجاهات الجمهور المصرى نحو الانتخابات

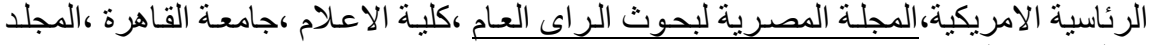
9،العدد 2،يوليه - ديسمبر الائرية 2008. 


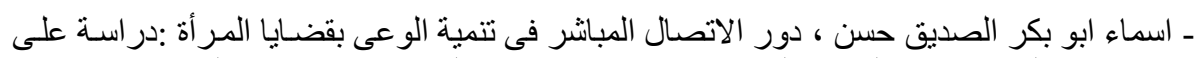

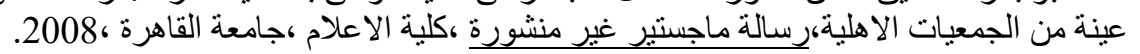

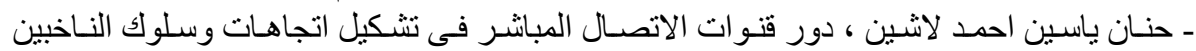

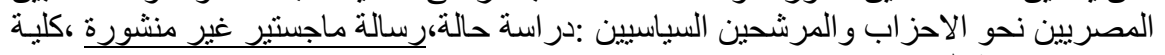

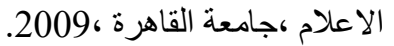

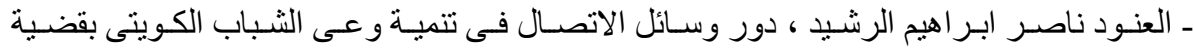

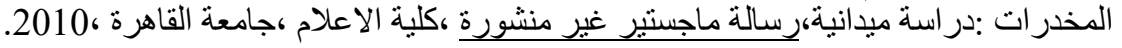

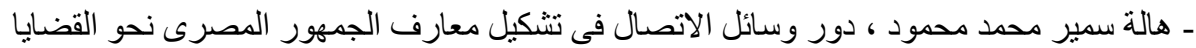

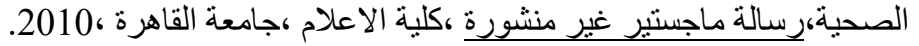

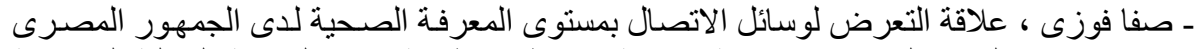

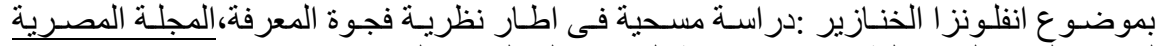

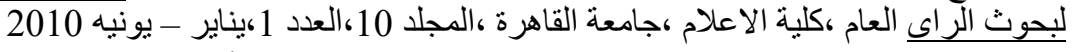

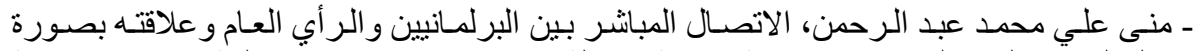

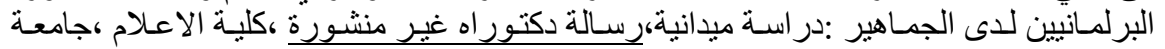

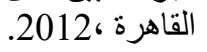

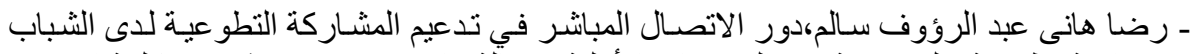

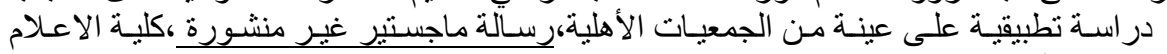

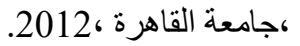
ـ وجدي عبد الرحمن شيخ بـاوزير دور الدعايـة الانتخابيـة في تفعيل المشـاركة السياسية في اليمن،

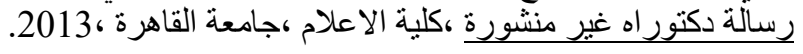

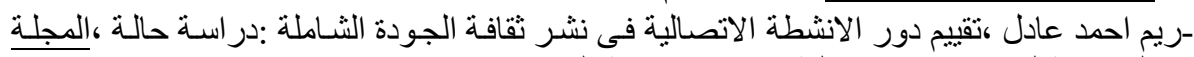

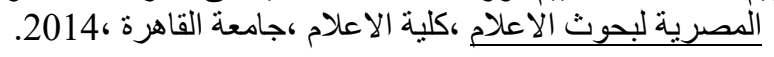

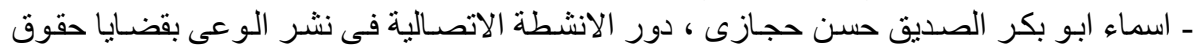

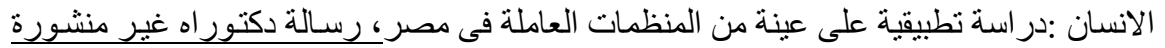

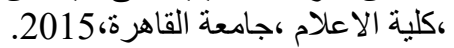

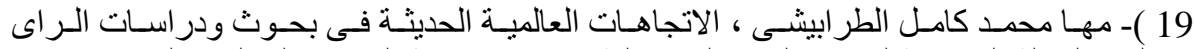
العام،المجلة المصرية لبحوث الراى العام ،كلية الاعلام ،جامعة القاهرة ،المجلد 5، العدد 1،يناير يونيه 2004.

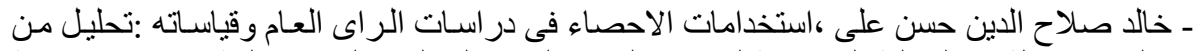

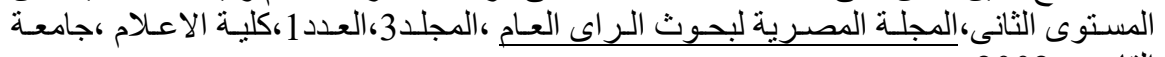

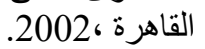

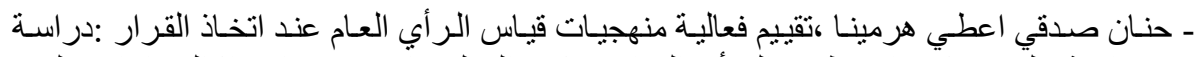

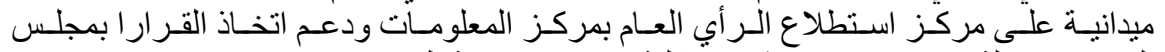

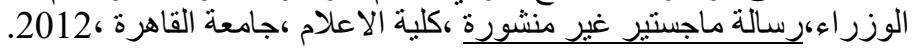

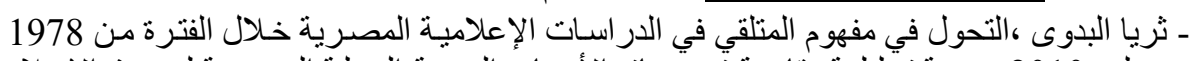

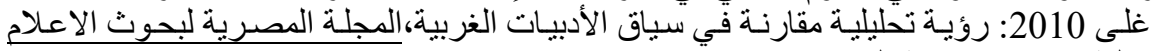
كلدكية الاعلام ،جامعة القاهرة ، 2012.

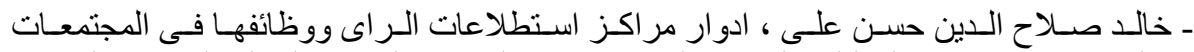

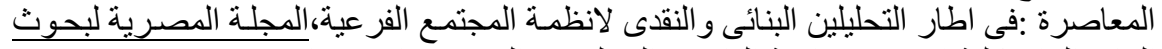

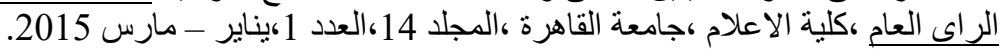




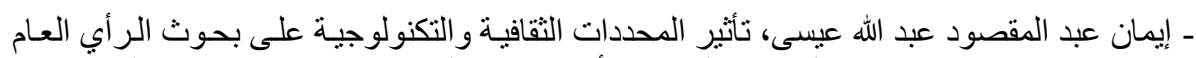

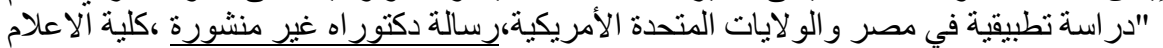
كامعة القاهرة ، 2013.

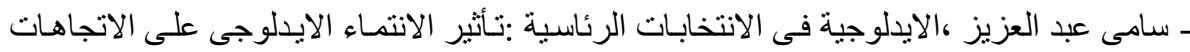

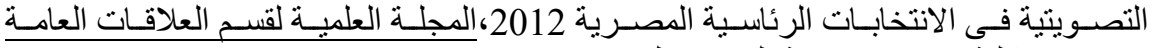

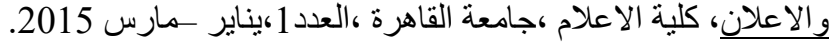

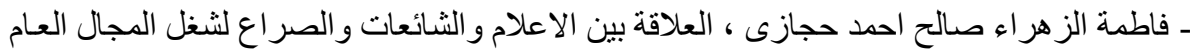

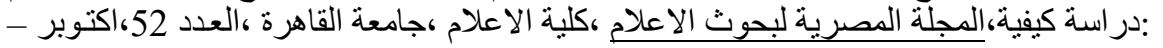
ديسمبر 2015.

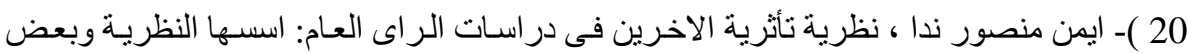

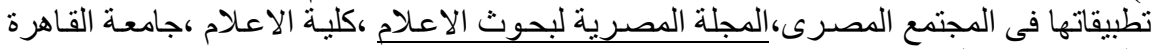

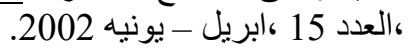

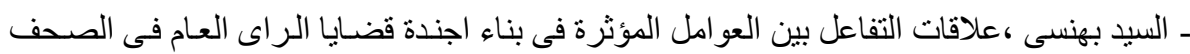

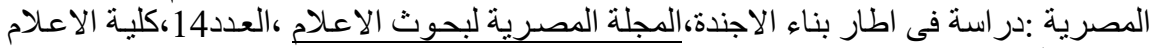

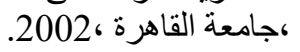

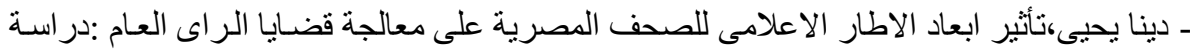

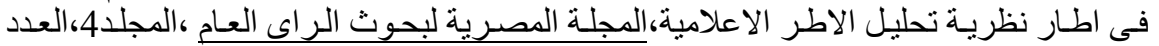

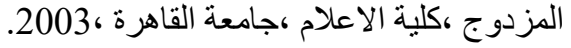

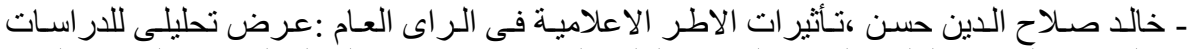

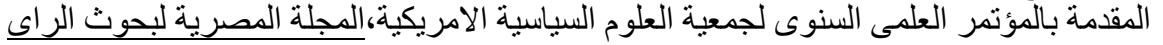

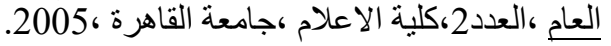

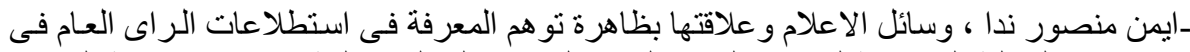

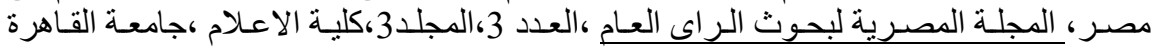
2002،

ـ شيماء ذو الفقار ، التليفزيون و علاقته بظاهرة التأرجح فى اتجاهات الراى العام فى مصر ،المجلة

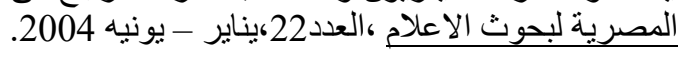

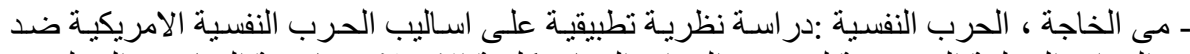

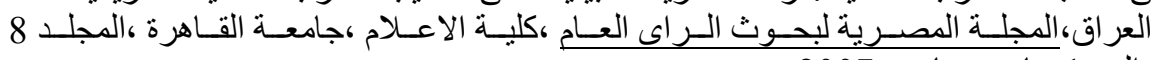

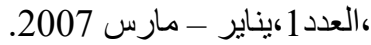

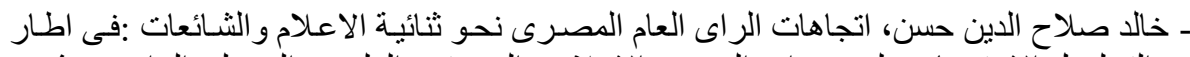

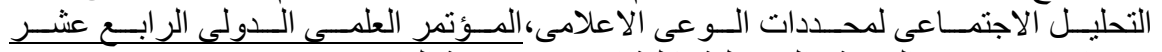

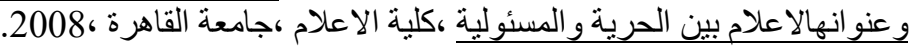

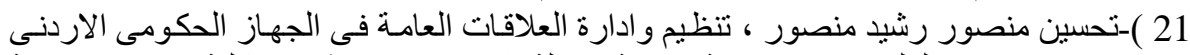

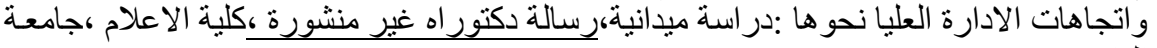

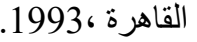
ـعصـام الدين احمد فرج ،الوظيفة الاتصـالية لمنظمـة التحريـر الفلسطينية ،رسـالة دكتور اه غير

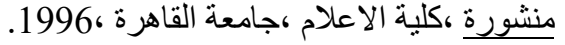

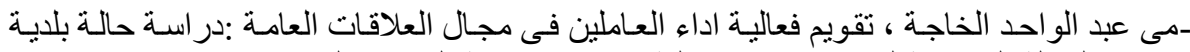

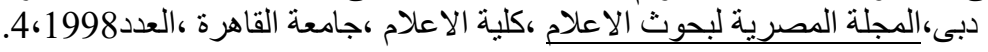


-خيرت معوض عباد، العلاقة بين ممارسي العلاقات العامة ووسائل الإعلام در اسة على المؤسسـات

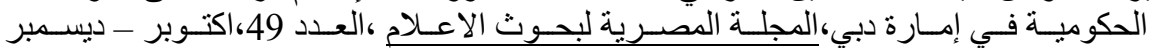
2014،كلية الآعلام ،جامعة القاهرة .

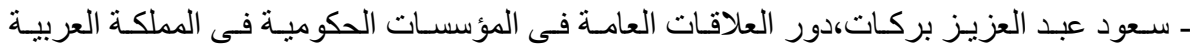

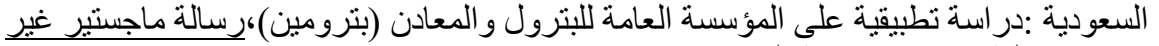

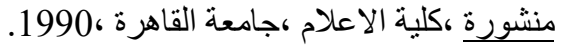

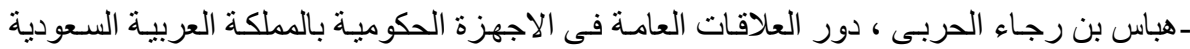

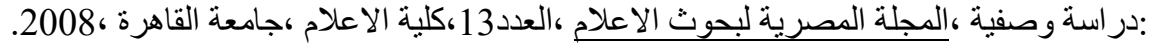

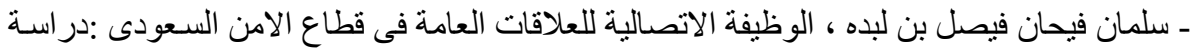

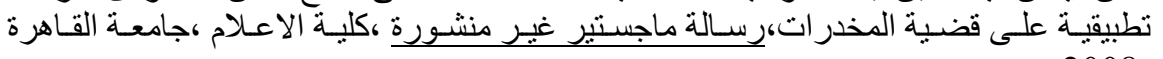
.2008،

ـ فؤاد على حسين سعدان،دور العلاقات العامة فى الاجهزة الحكومية فى الجمهوريـة اليمنية ،رسـالة

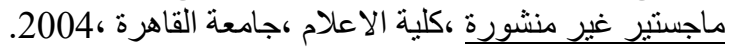

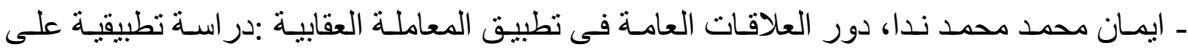

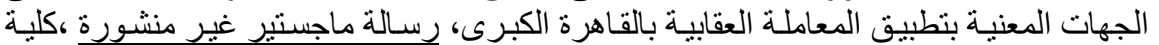

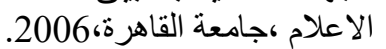

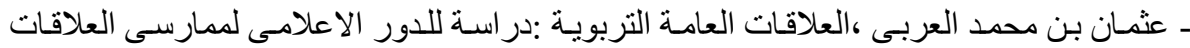

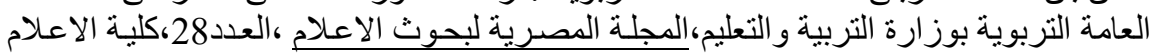

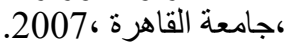

ـ عبير خميس محمد المخمرى ، دور العلاقات العامـة في إقناع الجماهير بدولة الإمـارات العربيـة

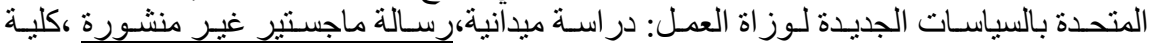

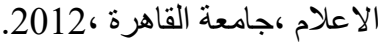

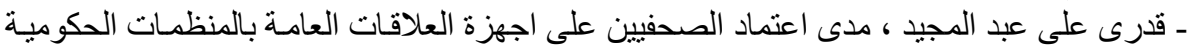
كمصادر للمعلومات :در استة ميدانية، المجلة العلمية لقسم العلاقات العامـة و الاعلاني ،كلية الاعلام

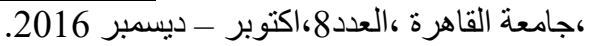

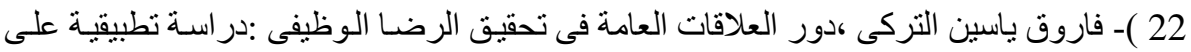

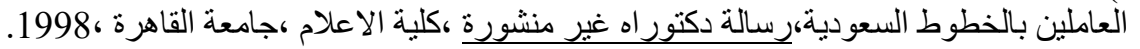

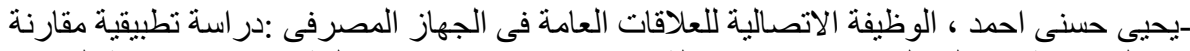

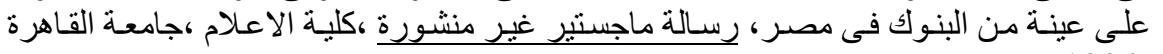
1994،

ـمددوح بسيونى البيلى ، اهداف ووظائف العلاقات العامة فى المؤسسات الصحفية فى مصر، رسـالة

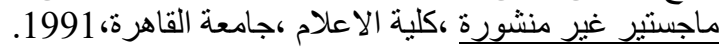

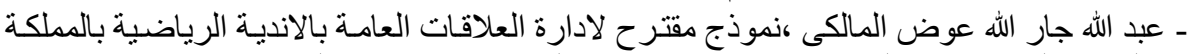

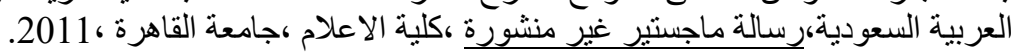

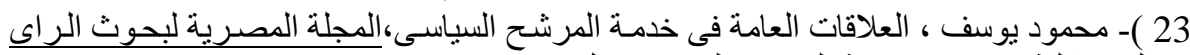

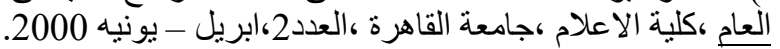

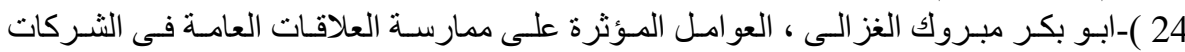

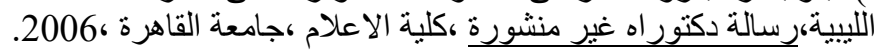

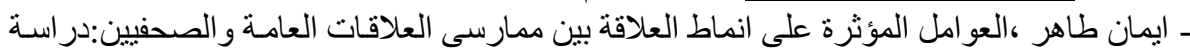
تطبيقية،رسالة ماجستير غير منشورة ،كلية الاعلام ،جامعة القاهرة ، 
بحوث العلاقات العامة والاعلان فى مصر :الواقع واتجاهات المستقبل

ـحنان فاروق محمد جنيد،تاثير العلاقات العامة على فاعلية الوظائف الاداريـة للمنشأة:در اسـة تحليلية

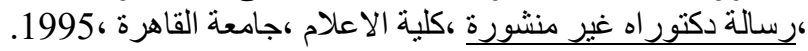

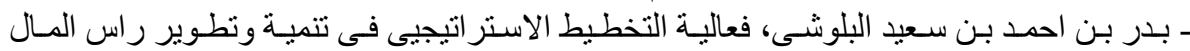

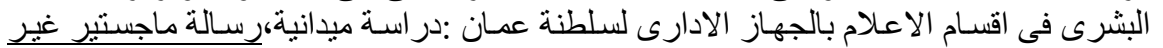

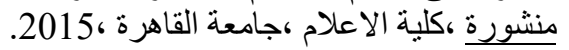

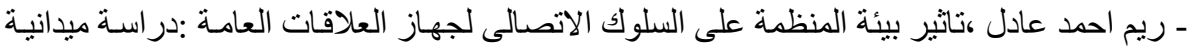

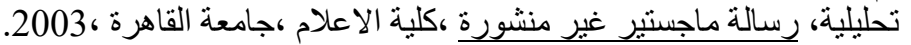

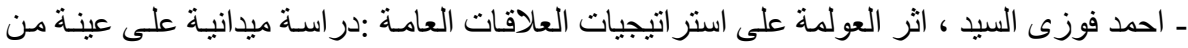

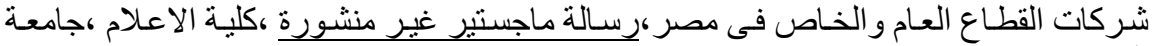

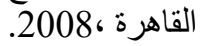

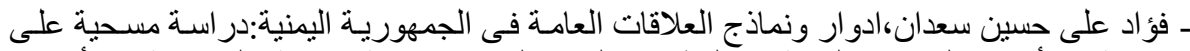

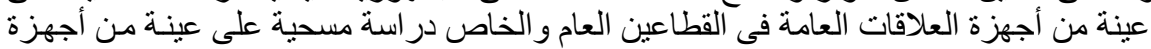

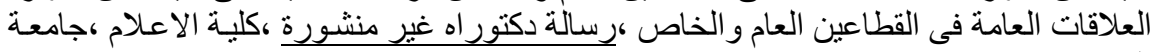

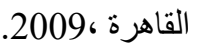

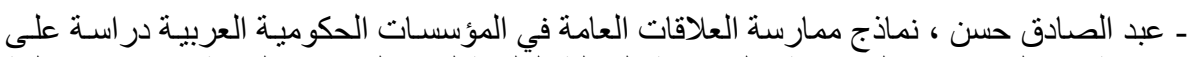

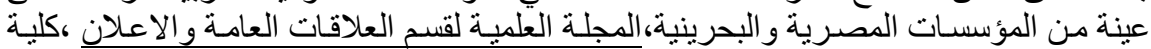

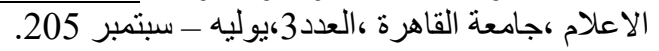

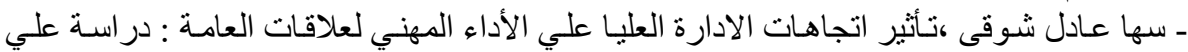

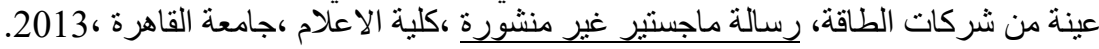

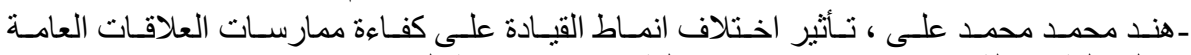

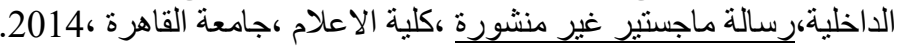

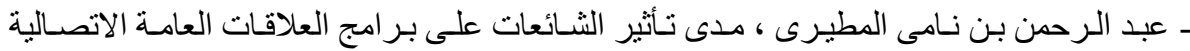

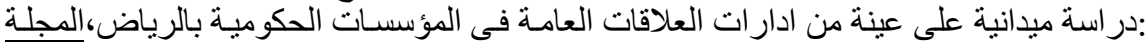

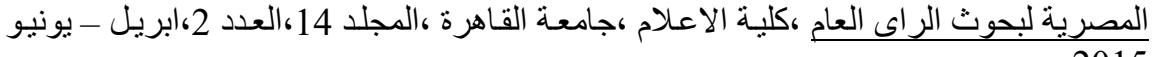
.2015

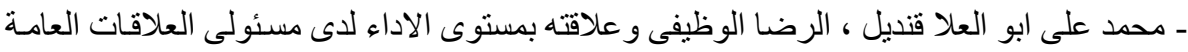

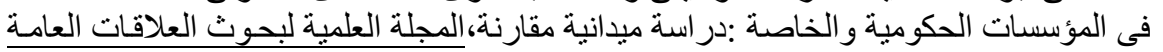

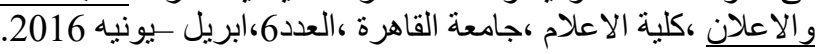

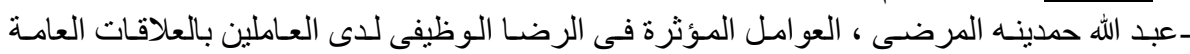

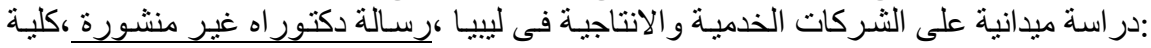
الاعلام ،جامعة القاهرة ، 2014.

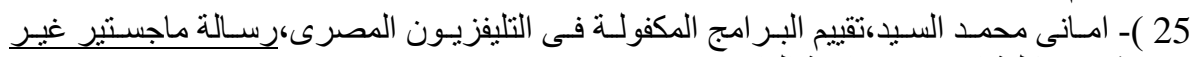
منشورة ،كلية الاعلام ،جامعة القاهرة ،2000.

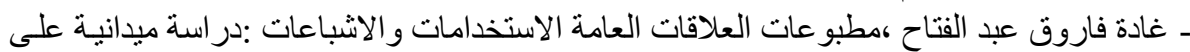

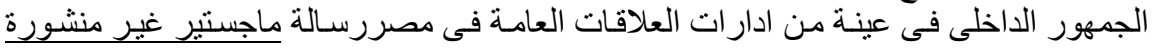

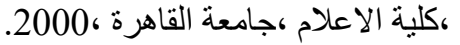

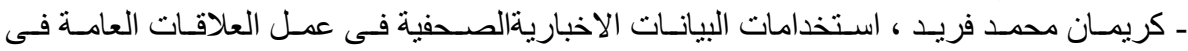
مصر، المجلة المصرية لبحوث الراى العام ،العدد 1،كلية الاعلام ،جامعة القاهرة ،2004. 
بحوث العلاقات العامة والاعلان فى مصر :الواقع واتجاهات المستقبل

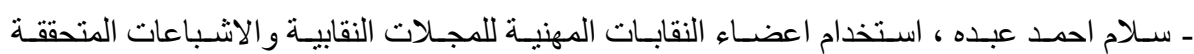

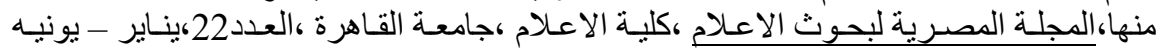
.2004

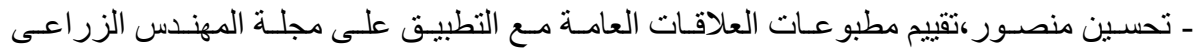

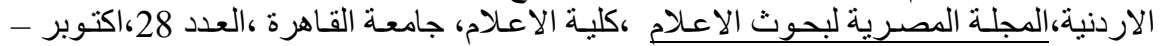
ديسمبر 2007 دئل

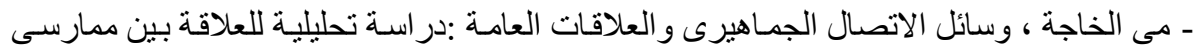

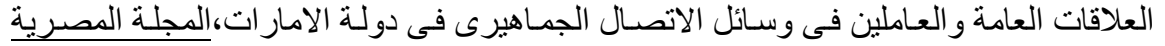

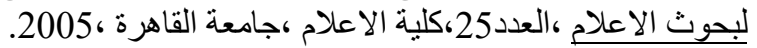

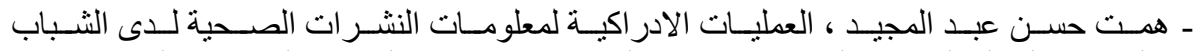
الجامعى،المجلة المصرية لبحوث اللاعلام ،كلية الاعلام ،جامعة القاهرة ،العدد 25،يوليه - ديسمبر العبر

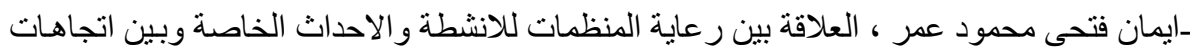

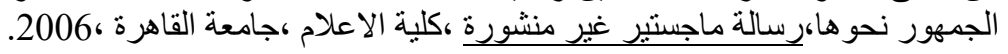

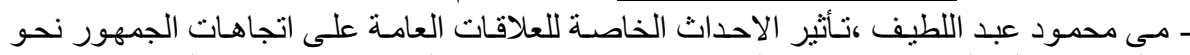

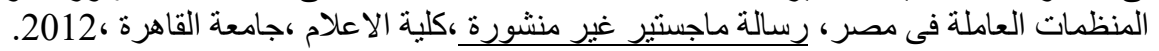

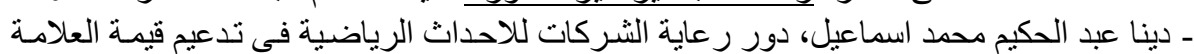

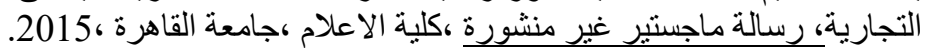

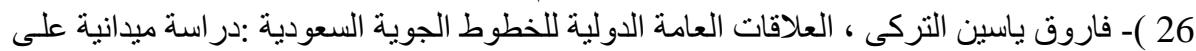

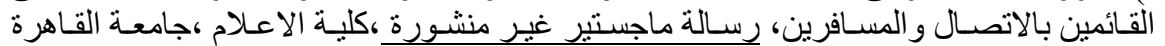
.1990،

ـ ايمان زهرة ، العلاقات العامـة في الشركات المتعددة الجنسية العاملة في مصر :در اسـة مسحية،

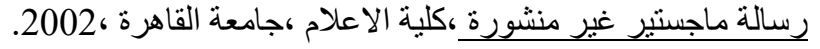

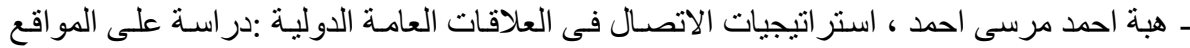

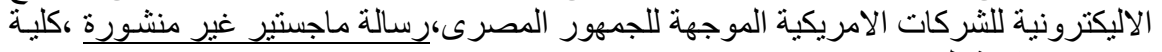

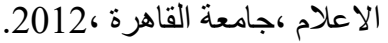

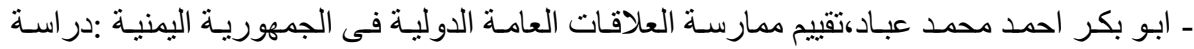
مسحية على عينة من الثركات الدولية، رسالة ماجستير غير منشورة ،كلية الاعلام ،جامعة العية

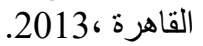

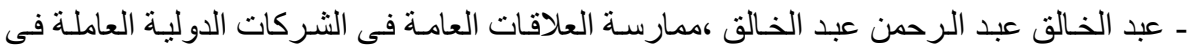

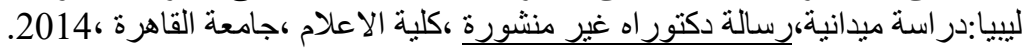

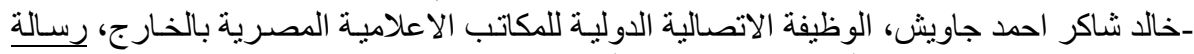
ماجستير غير منثورة ،كلية الاعلام ،جامعة القاهرة ،

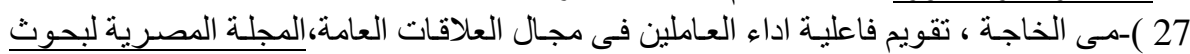

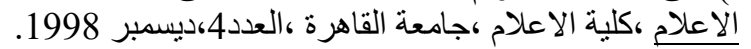

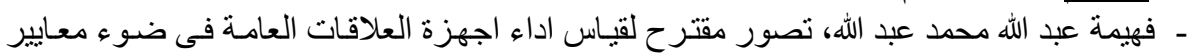

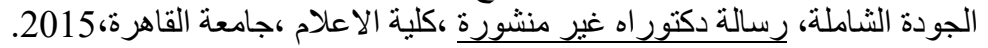

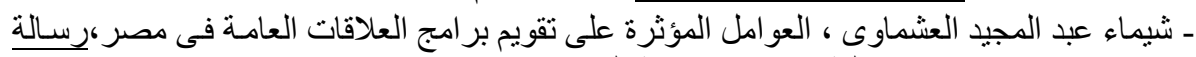
ماجستير غير منشورة ،كلية الاعلام ،جامعة القاهرة ،2015. 


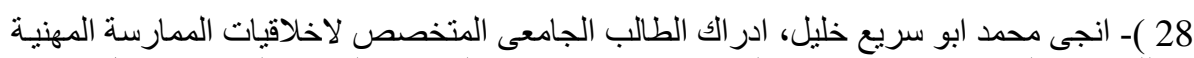

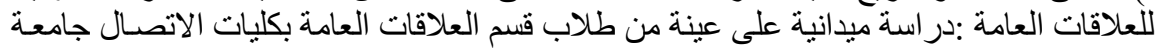

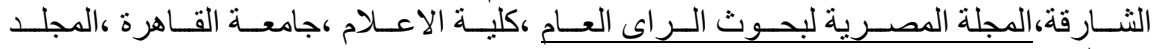
14،العدد4،اكتوبر - ديسمبر الكير 2015.

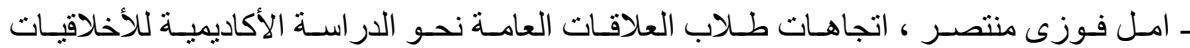

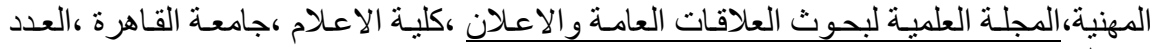

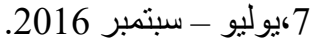

29 )-ريم احمد عادل ، تشخيص الاستر اتيجيات الاتصالية لادارة القضايا :در اسـة مقارنـة على عينة

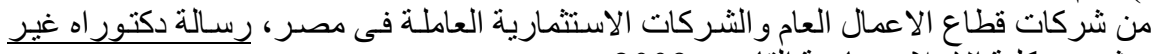

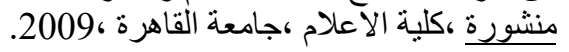

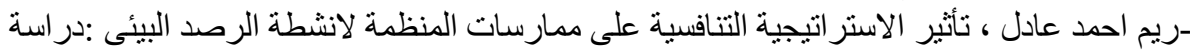

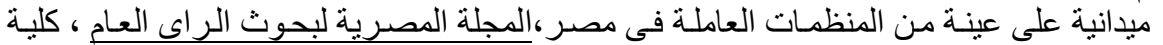

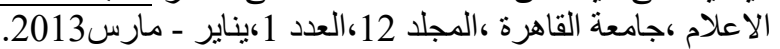

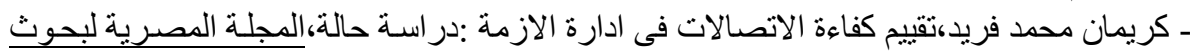

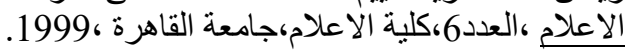

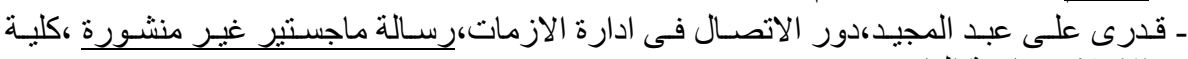
الاعلام ،جامعة القاهرة ، 2002.

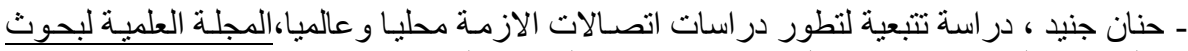

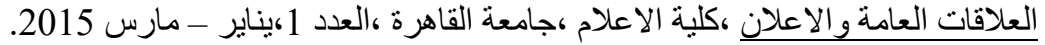

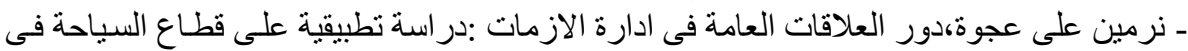

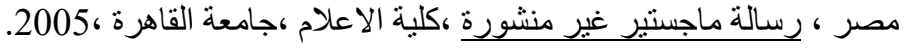

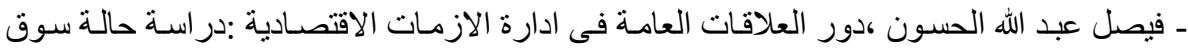

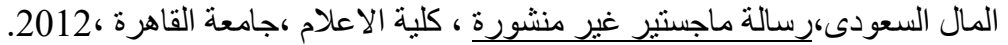

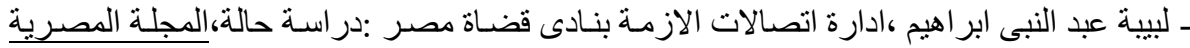

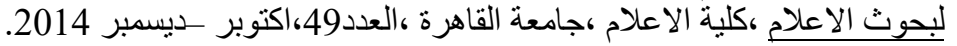

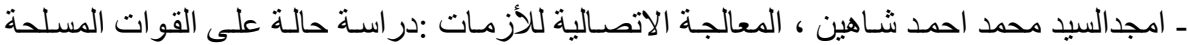

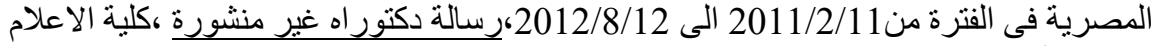

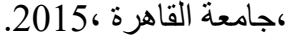

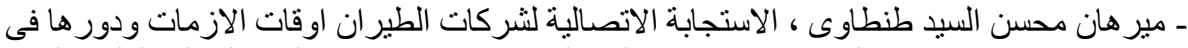

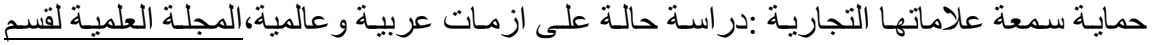

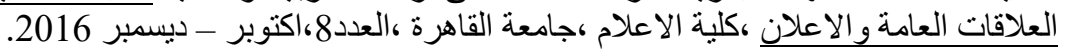

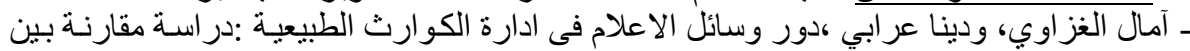

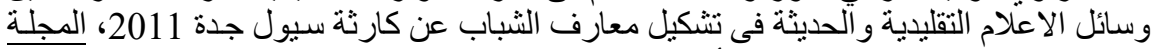

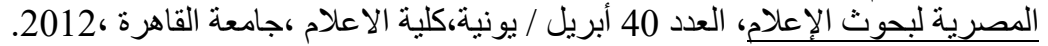

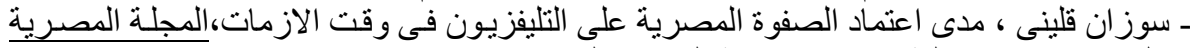

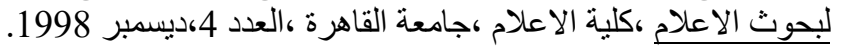

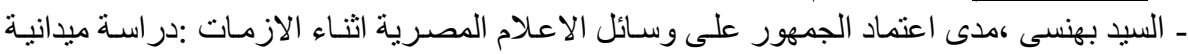

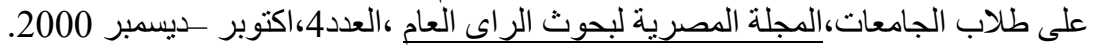


-رفعت على الضبع، اعتماد الجمهور المصرى على وسائل الاعلام لاكتساب المعلومات عن انفلونزا

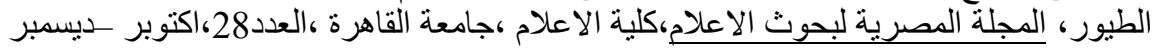

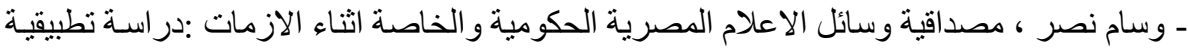

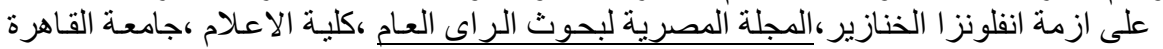

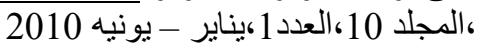

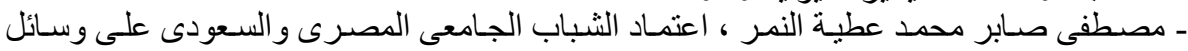

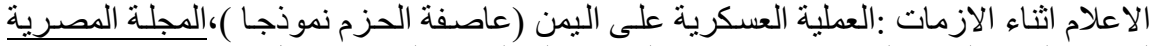

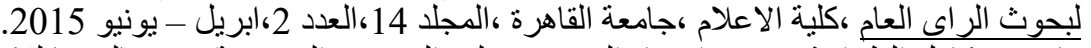

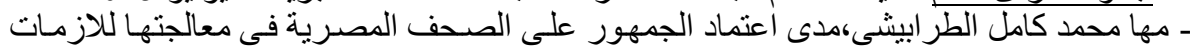

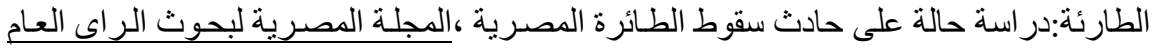

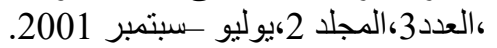

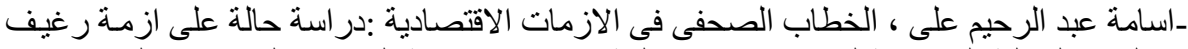

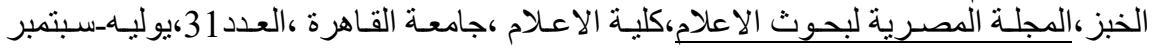
2008

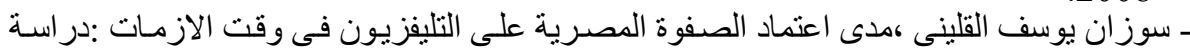
حالة على حادث الاقصر الار هابى،المجلة المصرية لبحوث الاعلام ،كلية الاعلام ،جامعة القاهرة

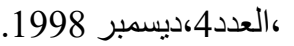

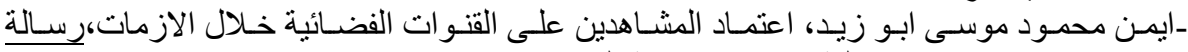

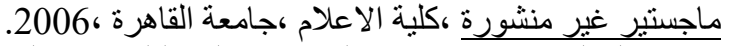

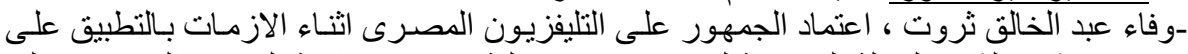
حادث شرم الثيخ، المجلة المصرية لبحوث الاعلام ،كلية الاعلام ،جامعة القاهرة ،العدد 25،يوليه عليه

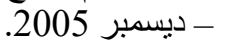

ـ نهى عاطف العبد،اعتماد الجمهور العربى على القنوات الفضـائية الاجنبية الموجهة باللغنة العربية

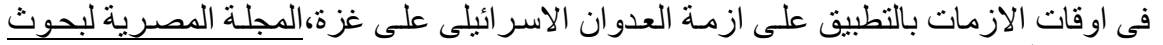

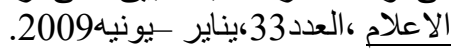

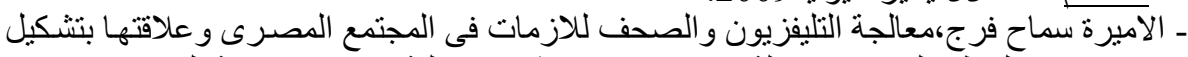

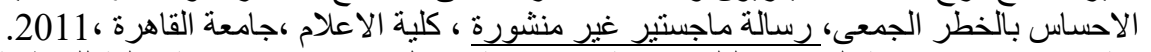

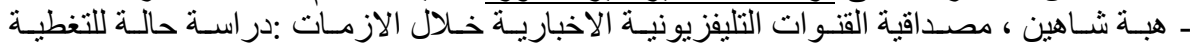

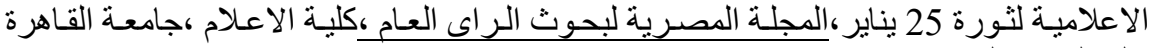

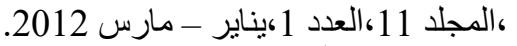

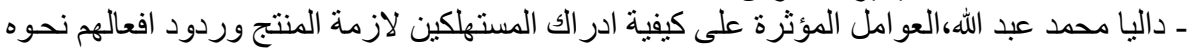

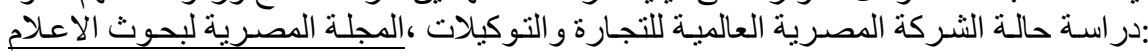

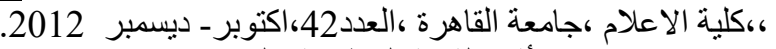

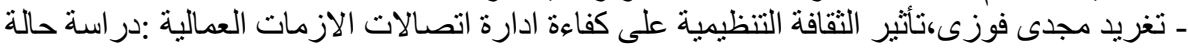

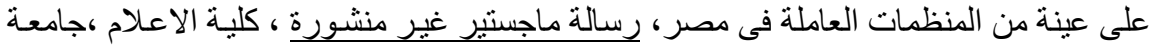

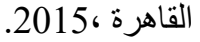

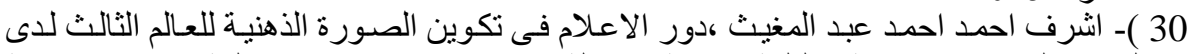

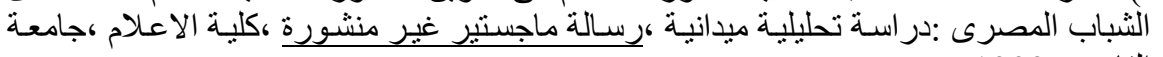

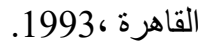
ـ ثريا احمد البدوى محمد ،"دور الاتصال فى تكوين الصورة الذهنيـة لدى الثـعب المصرى ،رسـالة ماجستير غير منشورة ،كلية الاعلام ،جامعة القاهرة ،1995. 
ـنرمين زكريا اسماعيل خضر ، صورة الو لايات المتحدة الامريكية لدى الجمهور المصرى :دراسة

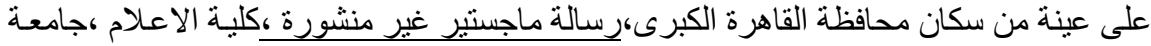

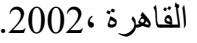

ـ محمد شومان ، صورة امريكا فى خطاب الاخوان المسلمين بمجلة الدعوة (1976-1981)، المجلة

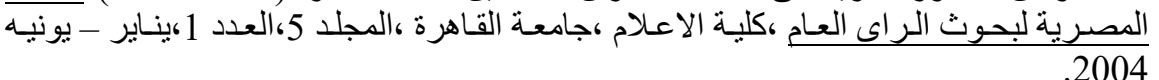

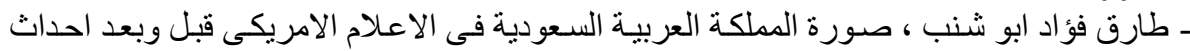

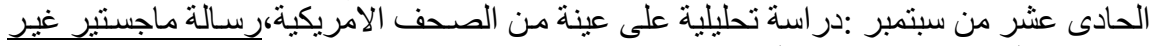

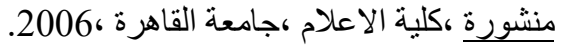

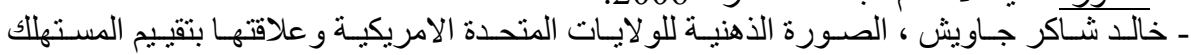

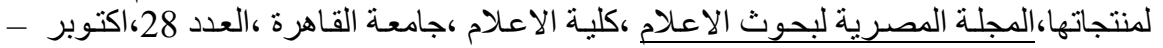
ديسمبر 2007

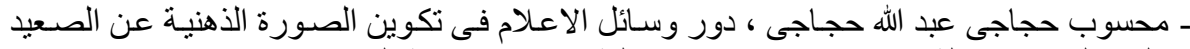

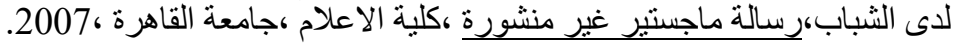

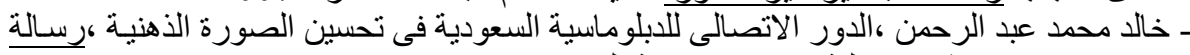

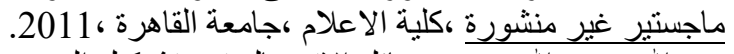

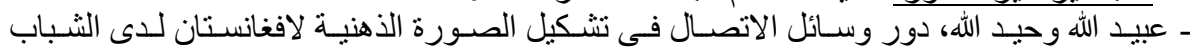

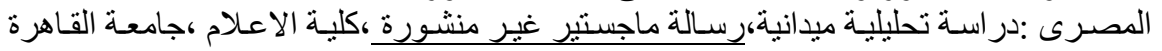

ــ بكر بن مصطفى بن محمد عثمان ، صورة المملكة العربية السعودية فى وسائل الاعلام الدولية بعد العادي

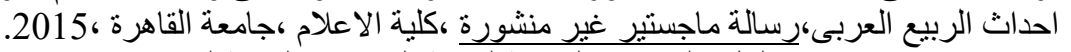

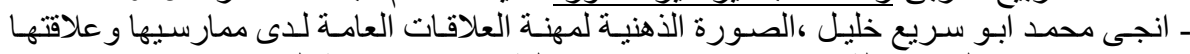

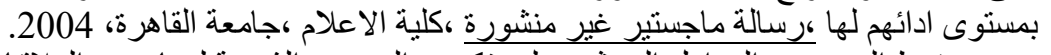

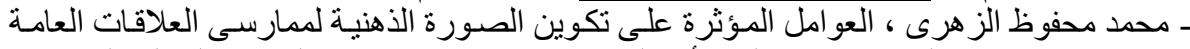

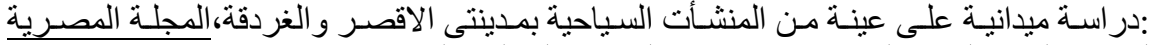

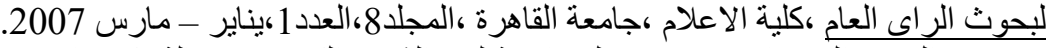

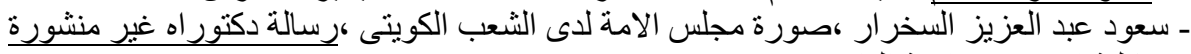
ـ كلية الاعلام ،جامعة القاهرة،

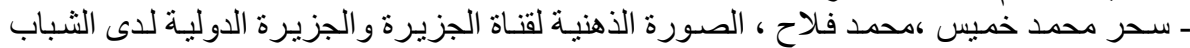

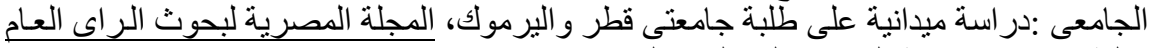

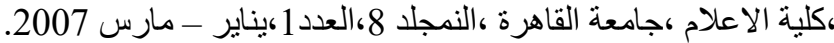

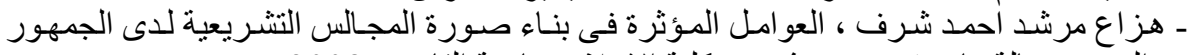

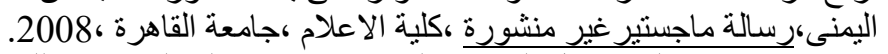

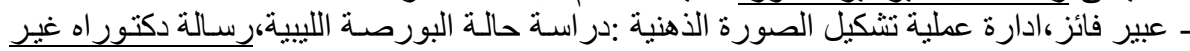

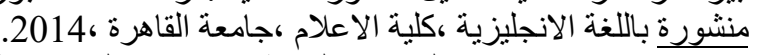

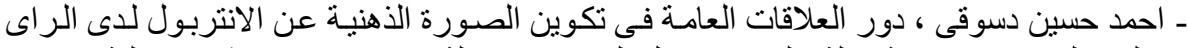

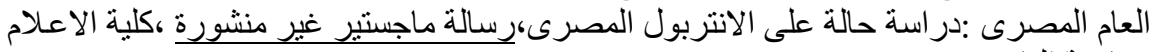

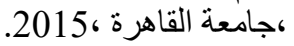

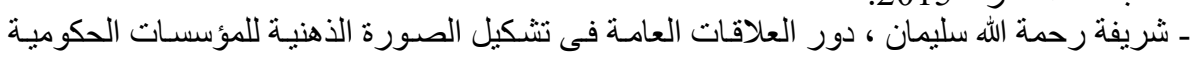

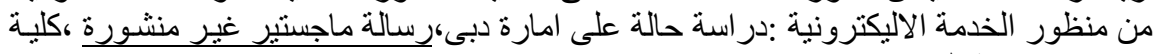

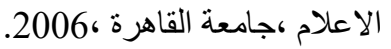


بحوث العلاقات العامة والاعلان فى مصر :الواقع واتجاهات المستقبل

ـ محمود إبر اهيم الدسوقي محمود ،صورة جهاز الثرطة عقب ثورة يناير 2011 وآليات تحسينها:

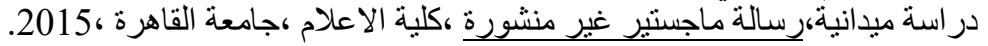

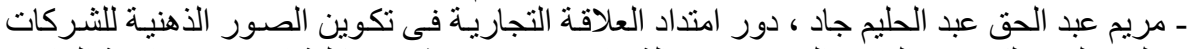

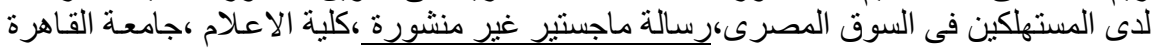

2015،

ـ سلوى سليمان ،تأثير متغير بلد المنشاعلى الصورة الذهنية للمنتج :در اسة تجرييية فى اطـار نظريـة

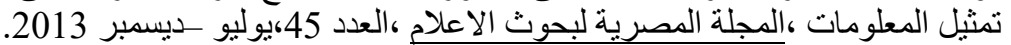

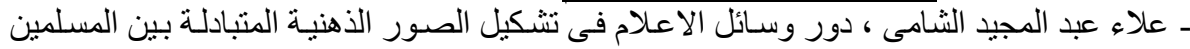

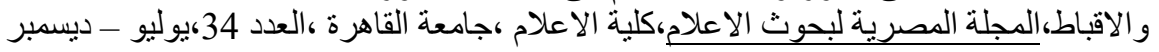

2009

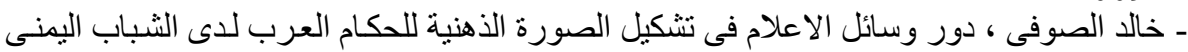

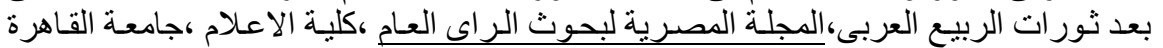

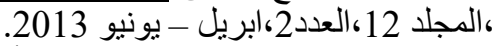

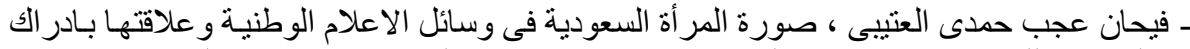

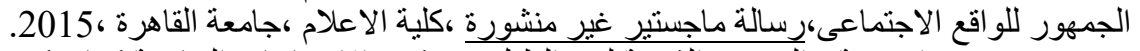

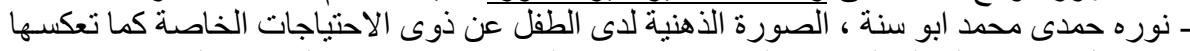
وسائل الاعلام،المجلة المصرية لبحوث الاععلام ،كلية الاعلام ،جامعة القاهرة ،العدد 52 52، اكتوبر

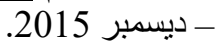

31 )-دعاء سليمان عاشور ، ادارة سمعة المنظمات المصرية و علاقتها بثقة الجمهور نحو ها،رسـالة

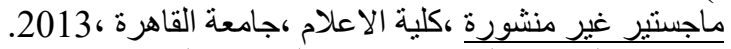

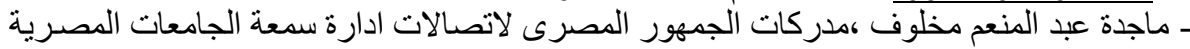

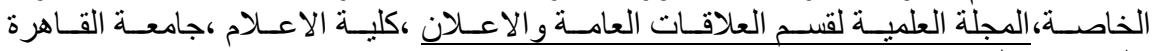

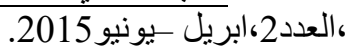

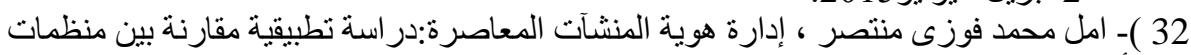

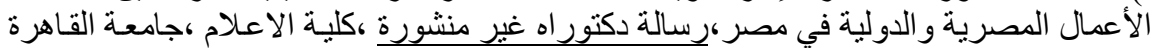
2010،

33 )ـ كريمان محمد فريد ،المسئولية الاجتماعيـة للعلاقات العامـة في الوحدات الاقتصـادية :در اسـة

ميدانية على عينة من شركات القطاعين العام والخاص،رسية لإلة دكتور اه غير منشورة ،كلية الاعلام كامعة القاهرة ، 1990.

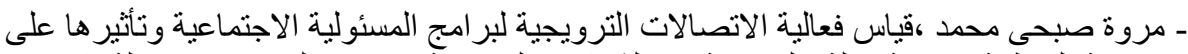

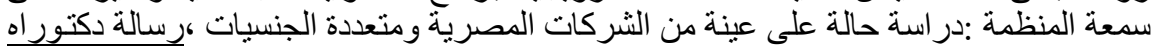

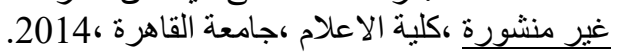

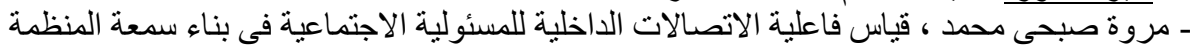

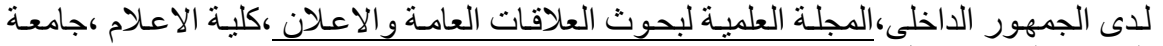

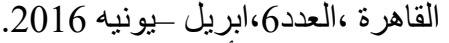

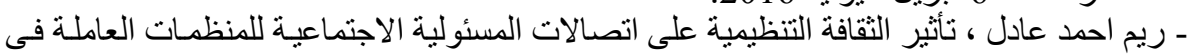

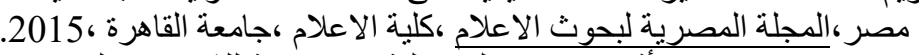

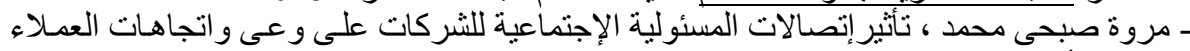

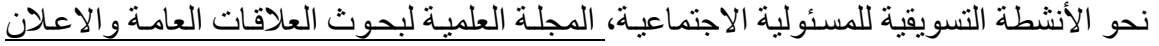

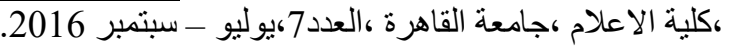

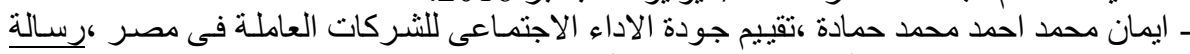
ماجستير غير منشورة ،كلية الاعلام ،جامعة القاهرة ،2016. 


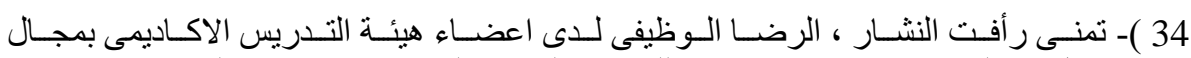

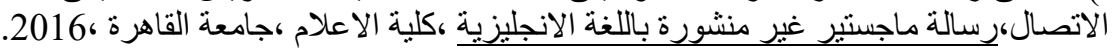

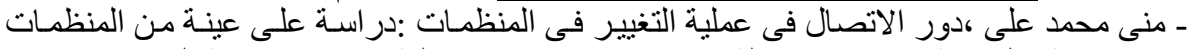

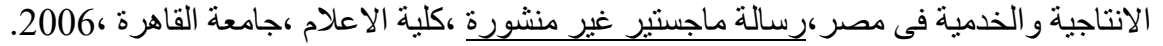

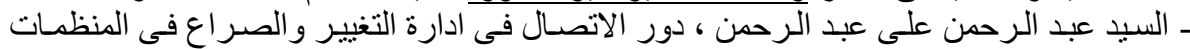
الحكومية :در اسة تطبيقية على وزارة التعليم العالى،رسالة ماجستير غيرة العير منشورة ،كلية الاعلام

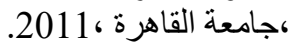
ـانجى محمد ابو سريع خليل ،كفاءة ادارة علاقات المنظمـة مع جماعات المصالح كرسالة دكتور اه

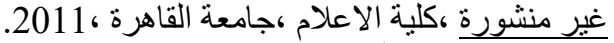

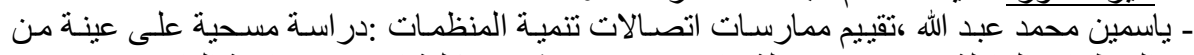

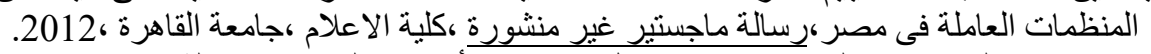

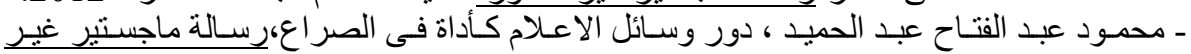

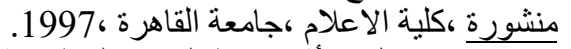

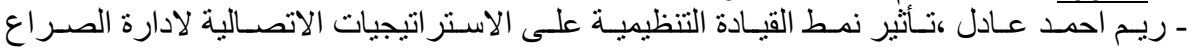

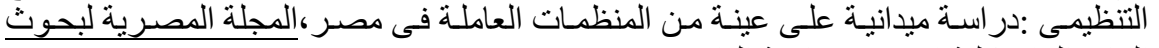

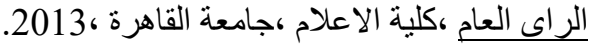

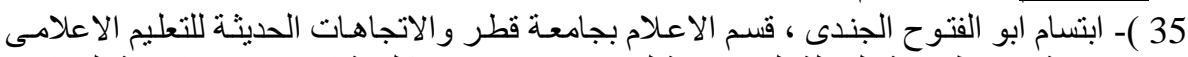

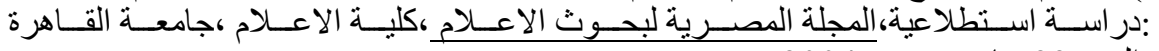

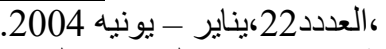

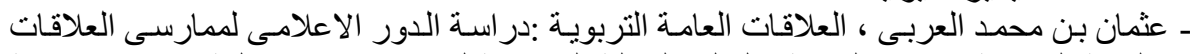

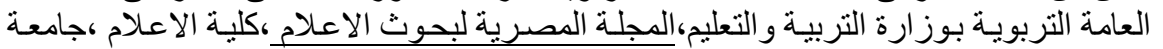

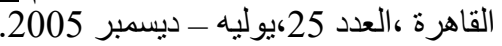

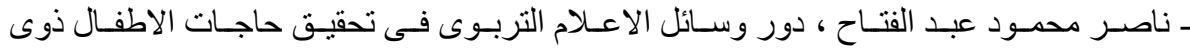

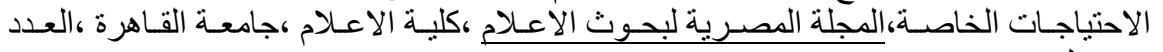

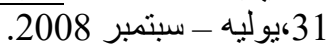

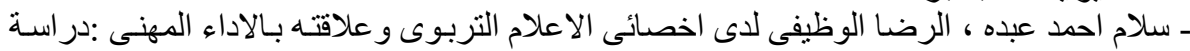

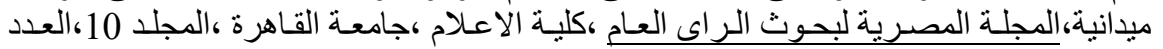

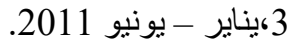

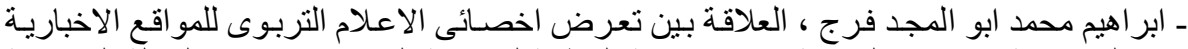

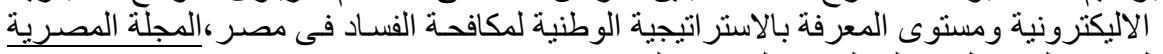

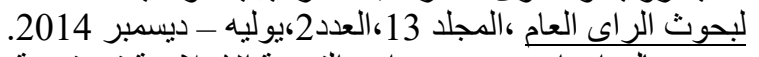

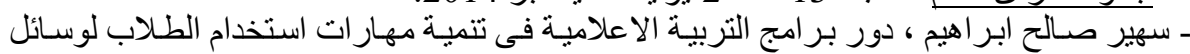

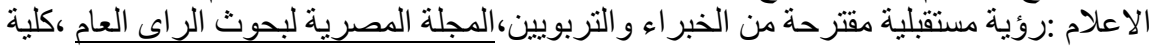

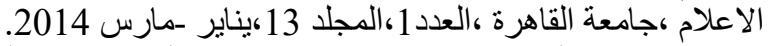

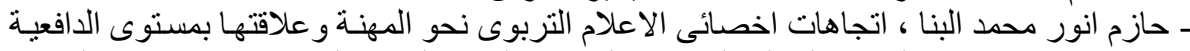

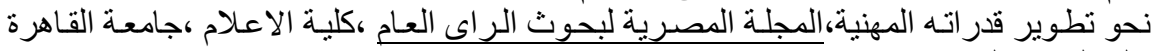

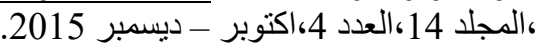

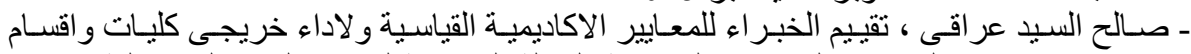

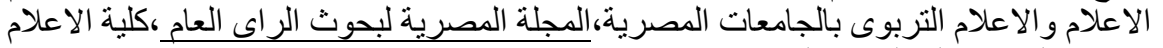

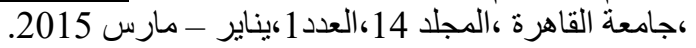




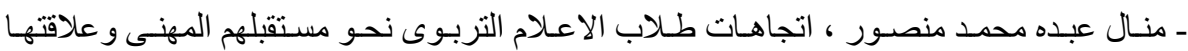

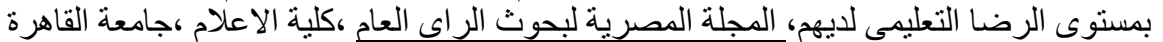

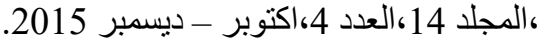

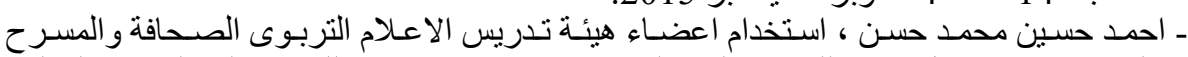

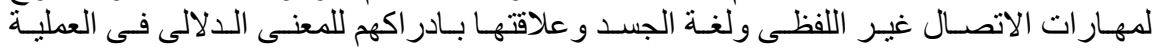

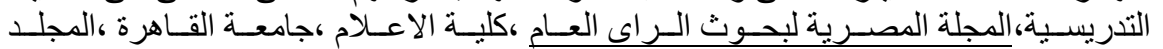

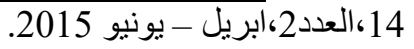

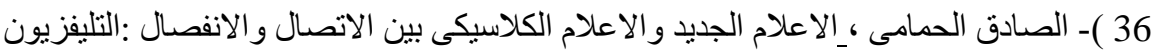

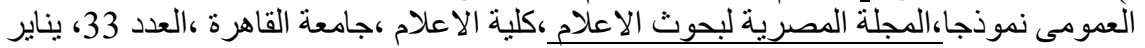
ـ عبير محمد حمدي ، دور الانترنت و الر اديو و التليفزيون في إمداد الجمهور المصري بالمعلومـات

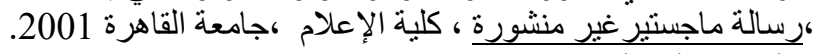

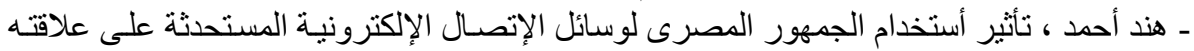

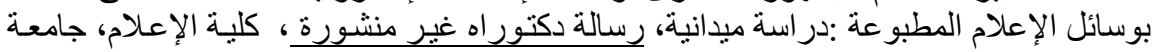

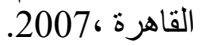

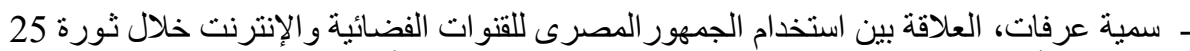

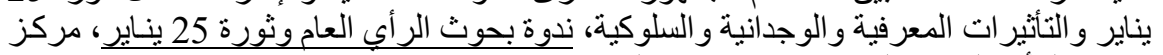

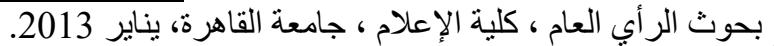

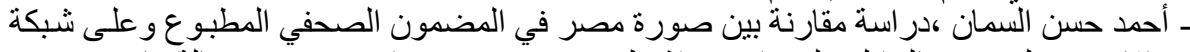

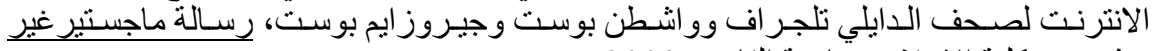

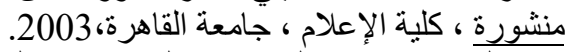

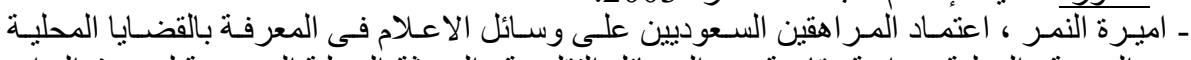

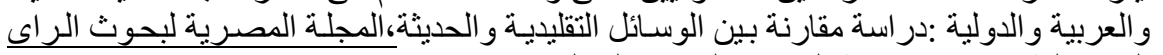

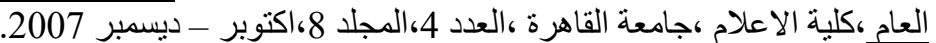

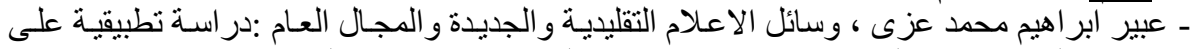

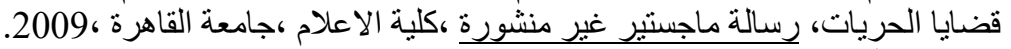

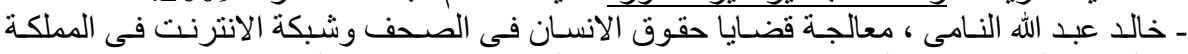

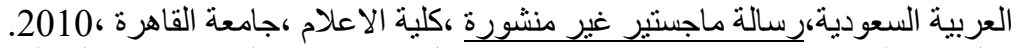

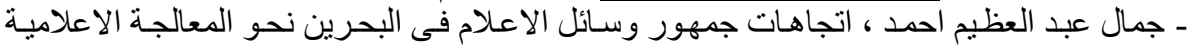

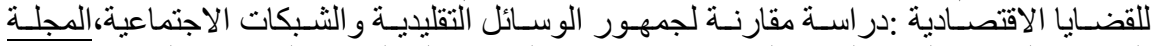

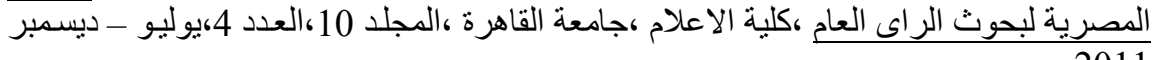

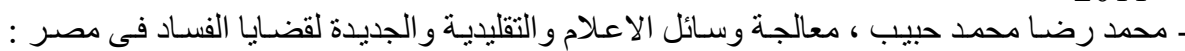

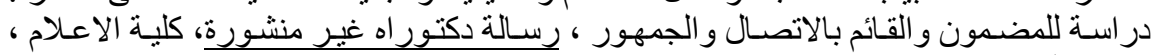
جامعة القاهرة، 2013. ـ هالة كمال نوفل ، تأثير الاعتماد على وسائل الاعلام التقليدية و الجديدة في الششاركة في الاستفتاء

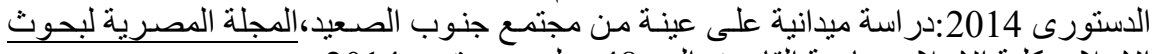

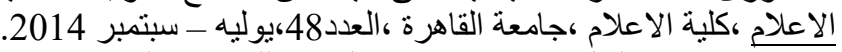

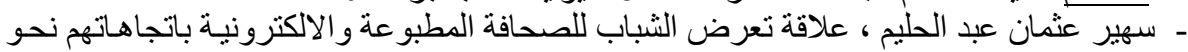

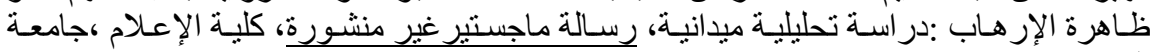

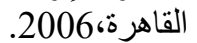




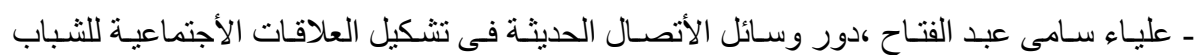

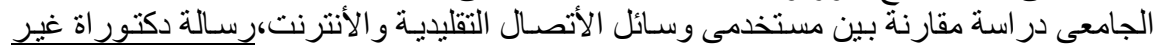

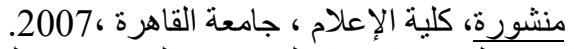

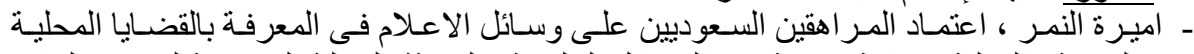

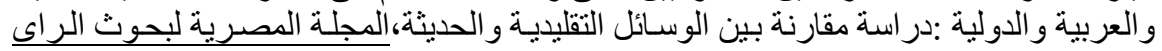

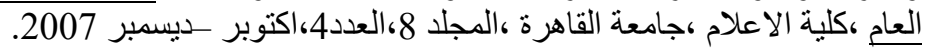

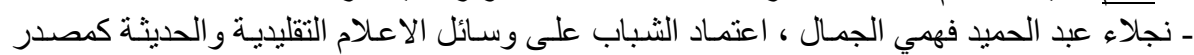

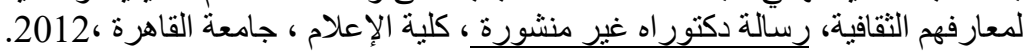

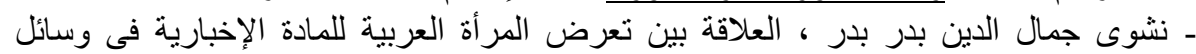

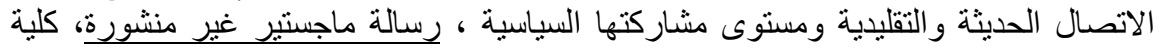
الإعلام ، جامعة القاهرة ،

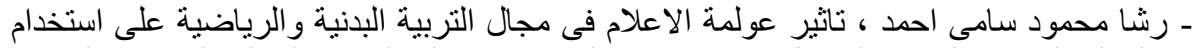

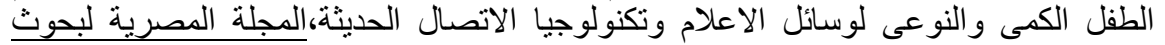
الاعلام ،كلية الاعلام ،جامعة القاهرة ،العدد 42،اكتوبر - ديسمبر الأهال 2012.

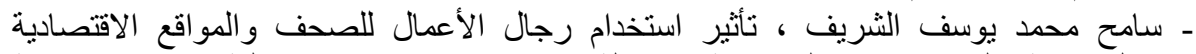

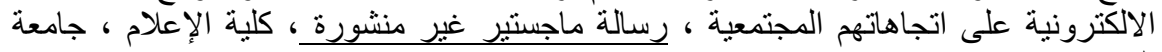
القاهرة ، 2013.

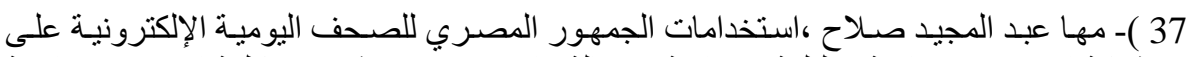

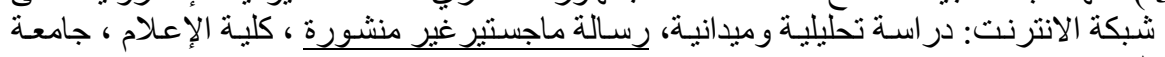

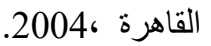

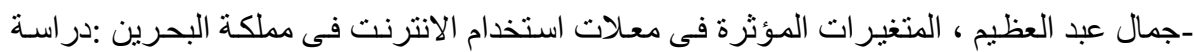

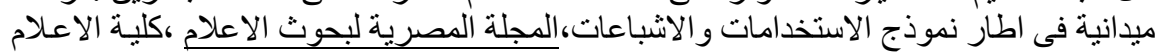

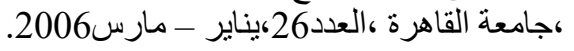

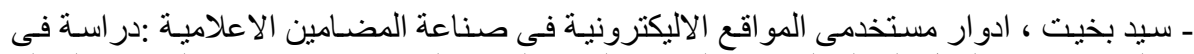

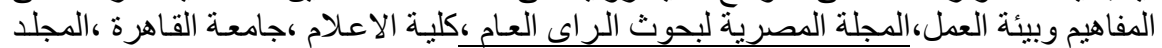
9،العدد 3،يناير - بونيو الميجية 2009.

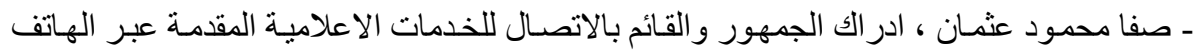
المحمول،المجلة المصرية لبحوث الاعلام ،كلية الاعلام ،جامعة القاهرة ،العدد 33،يناير - يونيه الإليه

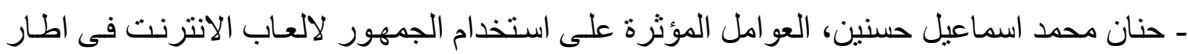

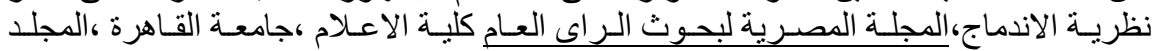

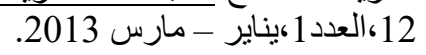

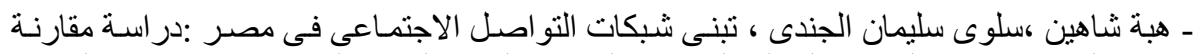

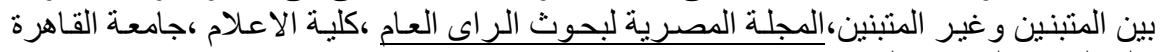

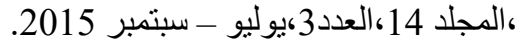

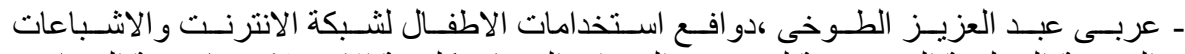

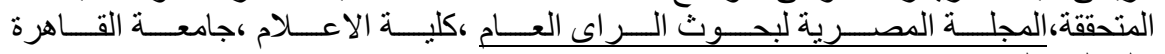
،المجلد3،العدد4،اكتوبر -ديسمبر العبر 2002. 
بحوث العلاقات العامة والاعلان فى مصر :الواقع واتجاهات المستقبل

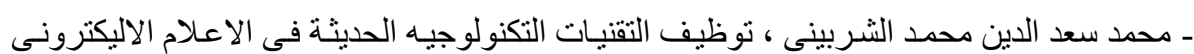

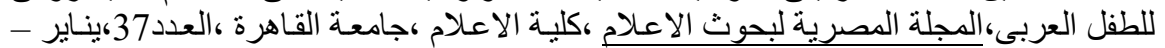

يونيه 2011.

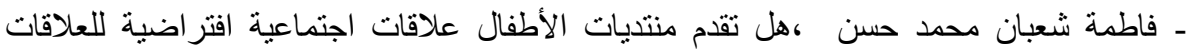

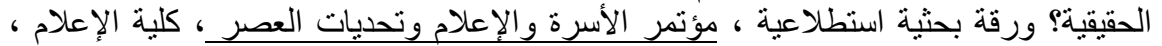
جامعة القاهرة ،فبر اير 2009.

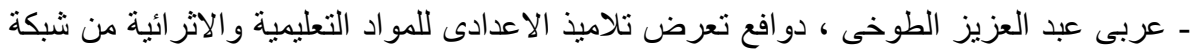

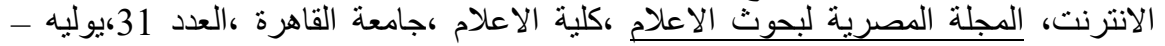

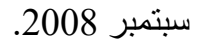

- رفعت عارف الضبع ، استخدام المر اهقين بالعالم العربى للفيس بوك والاثشباعات المتحققة لديهم

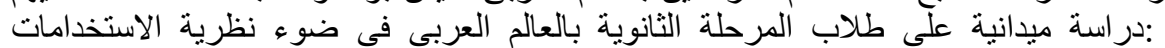

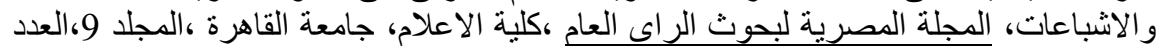

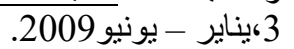

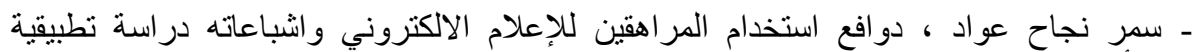

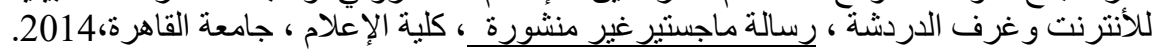

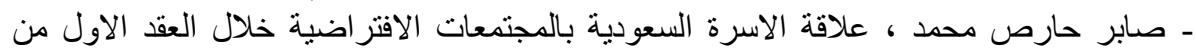

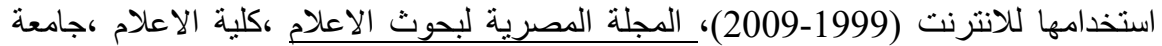
القاهرة ،العدد 34،يوليو - ديسمبر الرنت 2009

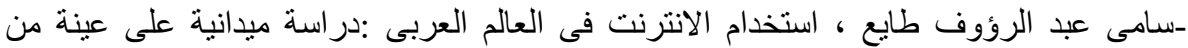

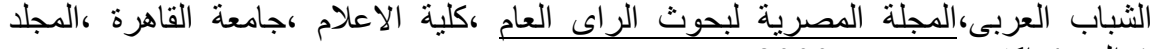

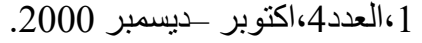

- ريم اسماعيل عبود ،استخدامات طالبات الجامعة فى مصر وسوريا لثبكة الإنترنت و الاشباعات

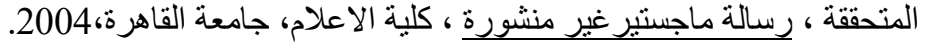

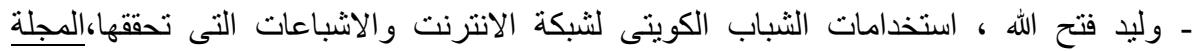

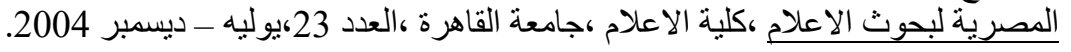

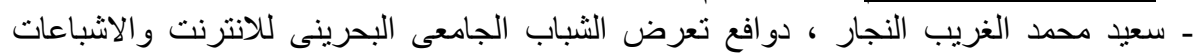

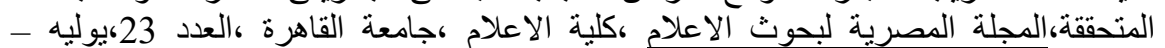
ديسمبر 2004.

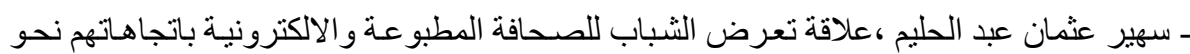

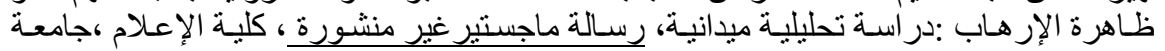

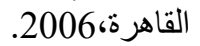

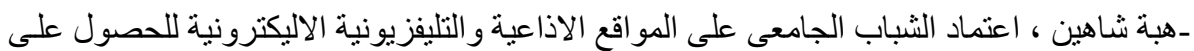

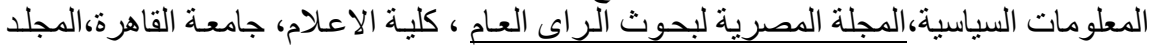

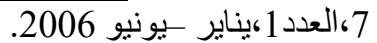

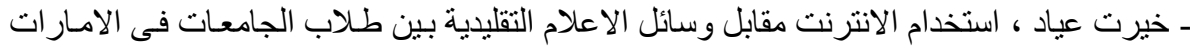

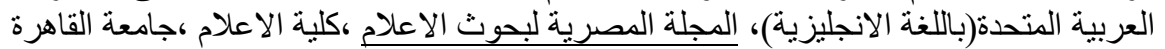

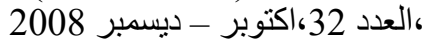

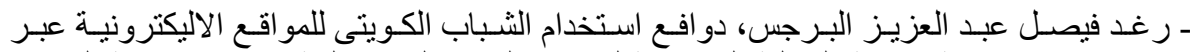

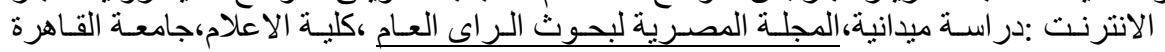
،المجلد 10،العدد3،يناير - يونيو 2011 


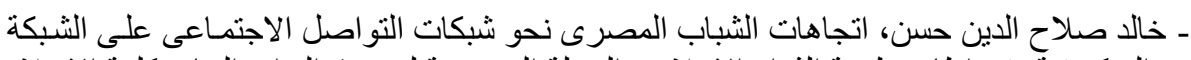

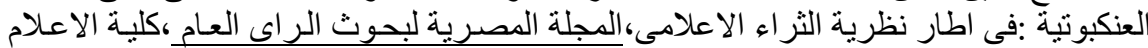

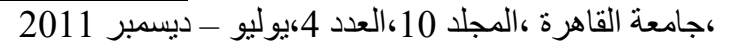

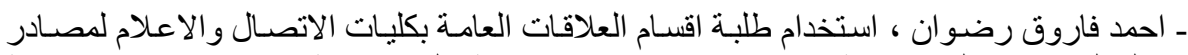

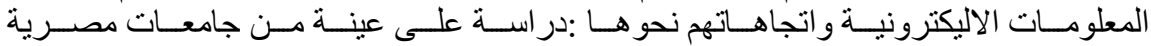

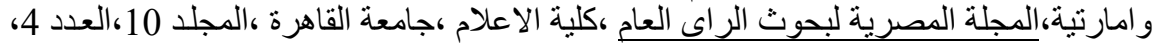

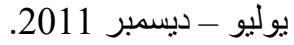

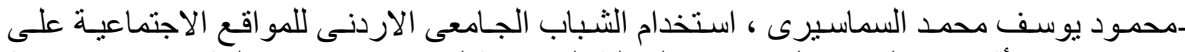

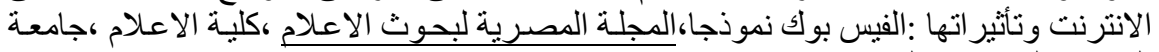

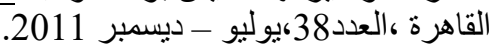

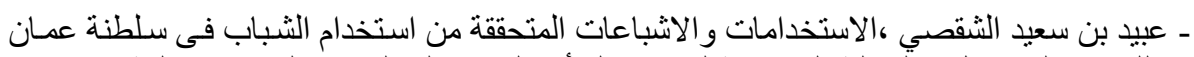

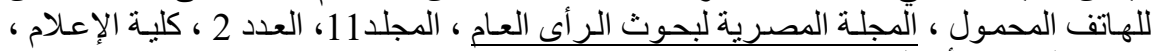

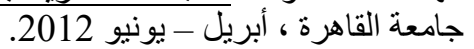

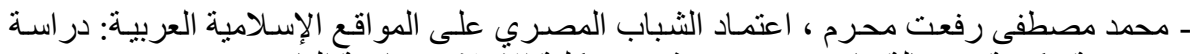

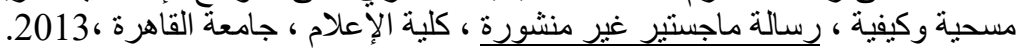

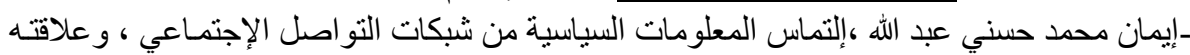

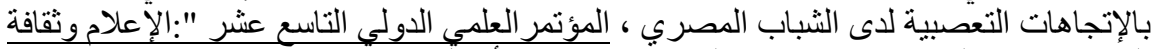

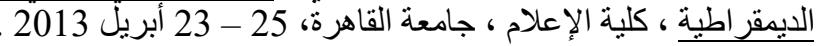

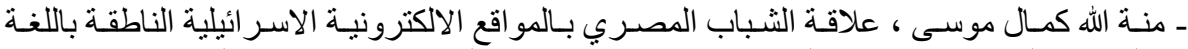

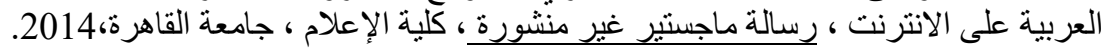

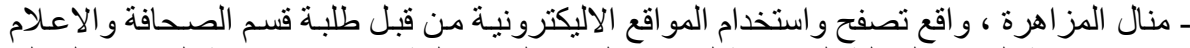

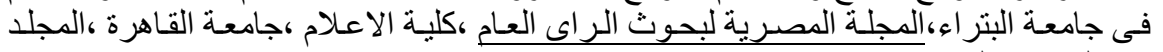

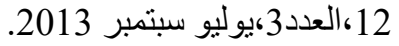

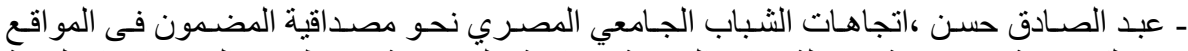

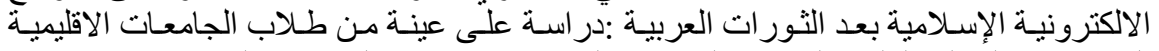

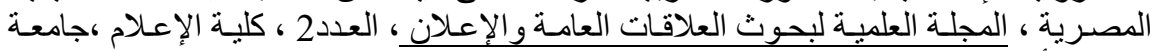

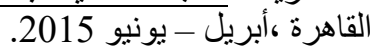

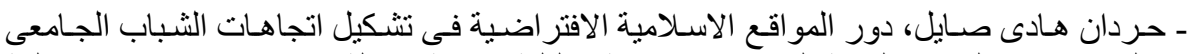

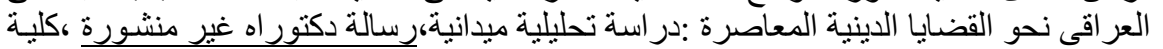
الاعلام ،جامعة القاهرة ، 2015.

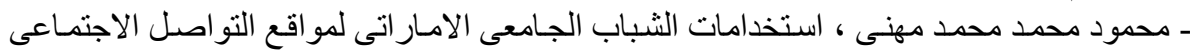
كمصادر للمعلومات الثقافية،رسالة ماجستير غير منشورة ،كلية الاعلام ،جامعة القابعة القاهرة ،2015.

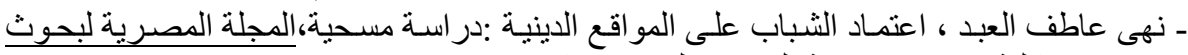

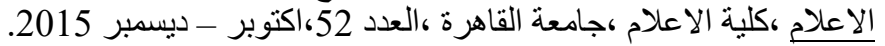

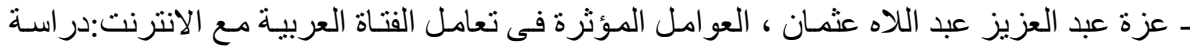

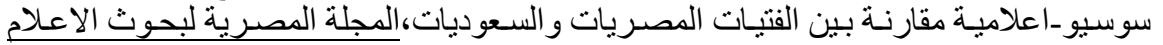

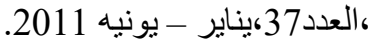

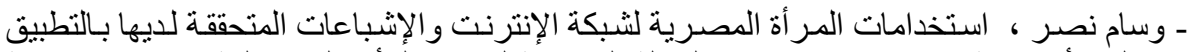

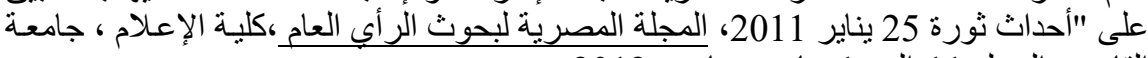
القاهرة، المجلد 11،العدد1، بناير - مارس 2012 ـ 2012 
ـ مصطفى سبد عبد اللاه ، محمود أحمد لطفي ، نورة عبد الله محمود ، استخدامات المر أة الصعيدية

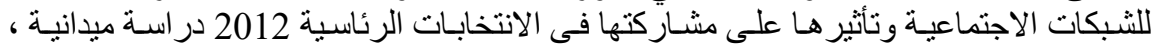
المؤتمر العلمي الدولي التاسع عشر "الإعلام وثقافةالديمقر اطية " ، كلية الإعلام ، جامعة القاهرة ، .2013

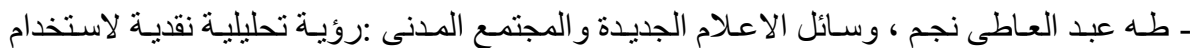

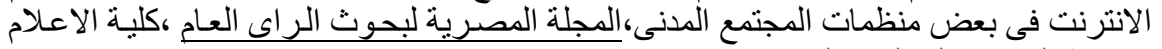

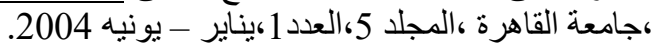

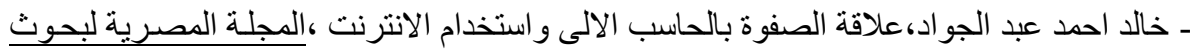

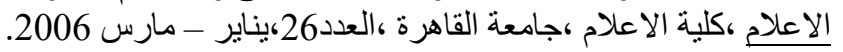

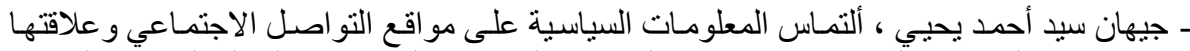

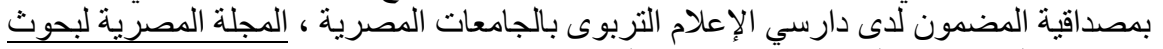

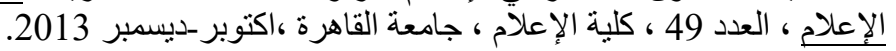

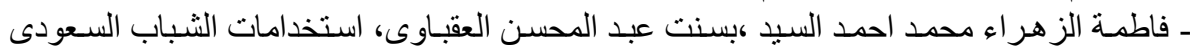

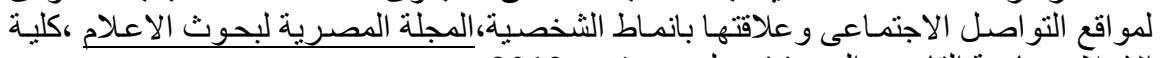

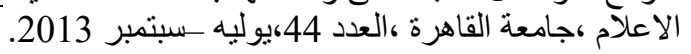

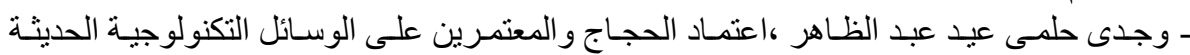

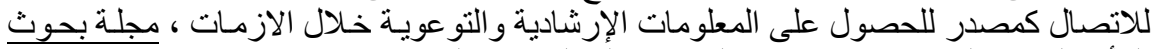

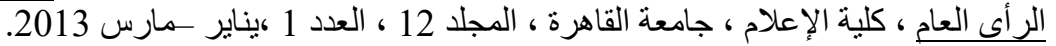

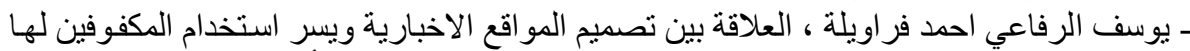

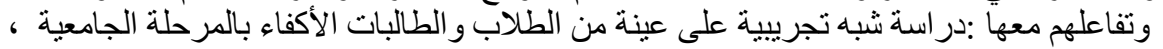

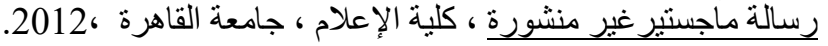

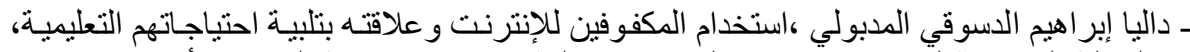

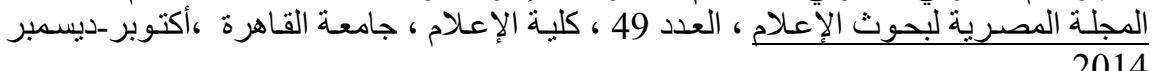

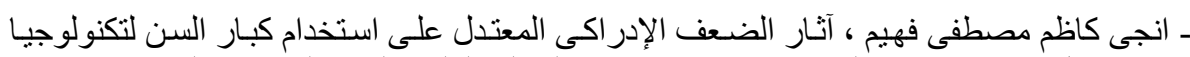

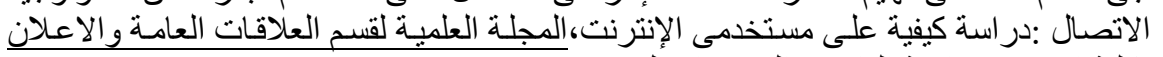

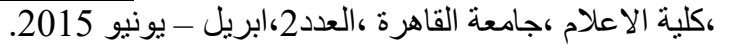

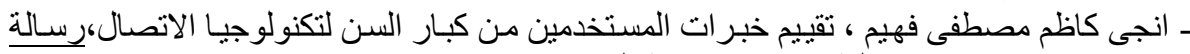
دكتور اه غير منشورة ،كلية الاعلام ،جامعة القاهرة ،

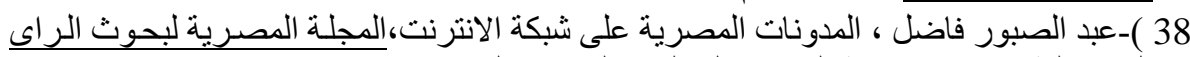

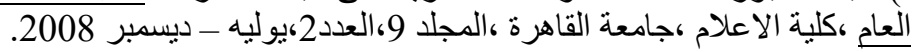

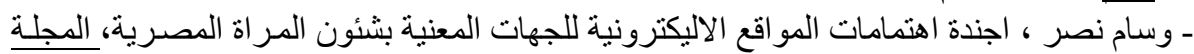
2008.

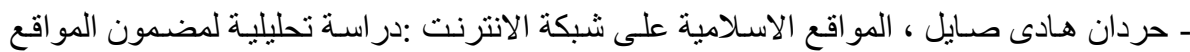

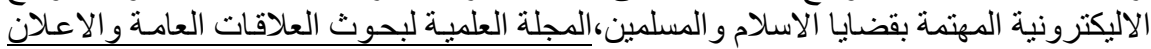

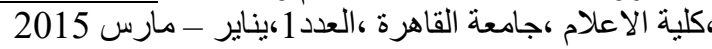

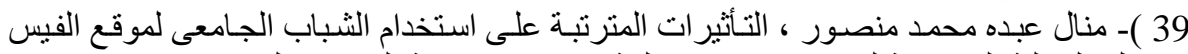

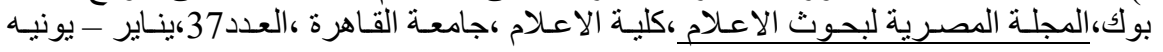
.2011 


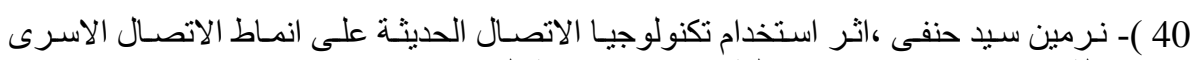

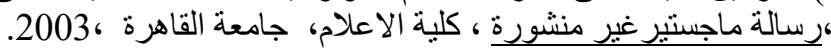

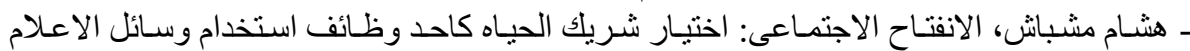

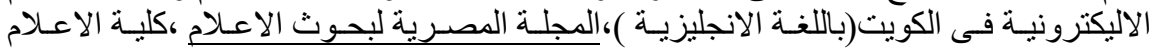

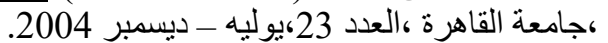

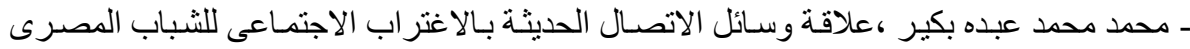

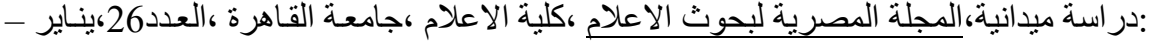

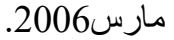

ـ منـال ابو الحسن،دور شبكة الانترنت في دعم الحوار الاسرى، المجلة المصرية لبحوث الاعلام

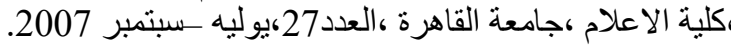

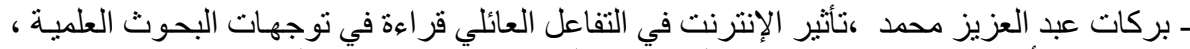

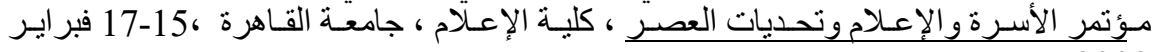

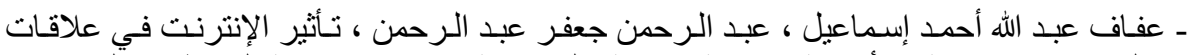

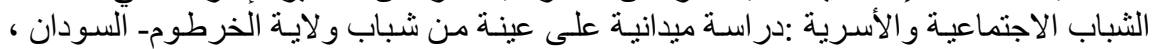

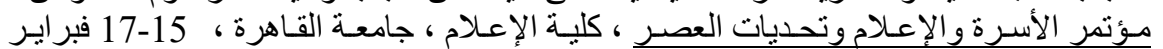
2009

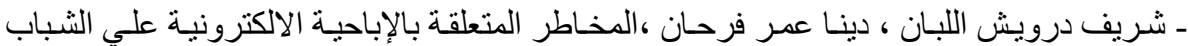

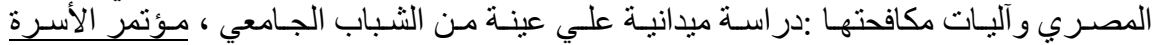

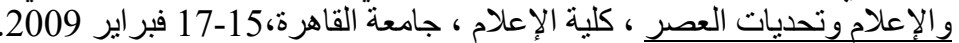

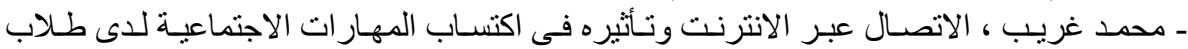

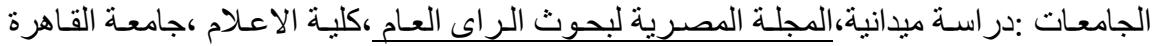

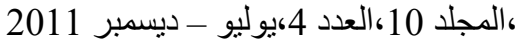

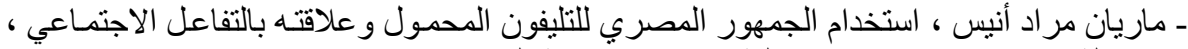

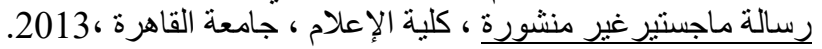

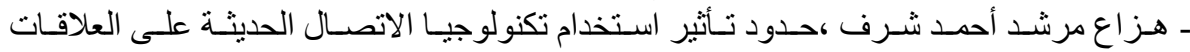

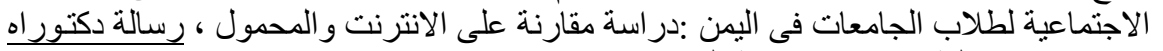

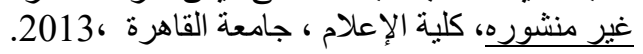

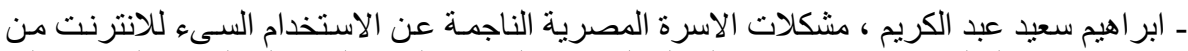
وجهة نظر الو الدين :در اسة ميدانية، المجلة المصرية لبحوث الرية الرئ العام ،المجلد 13،العدد2،يوليه

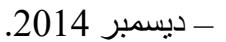

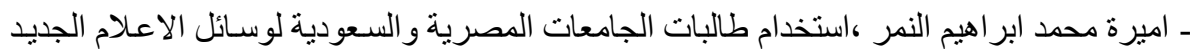

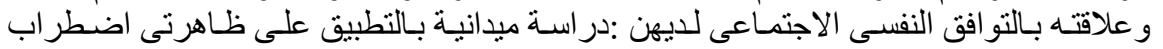

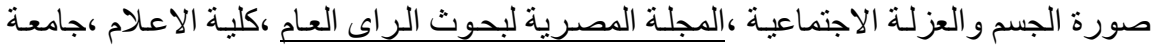

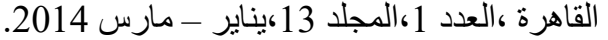

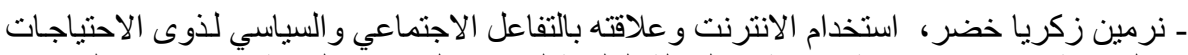

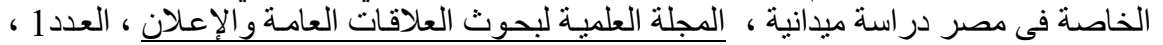
كلية الإعلام جامعة القاهرة،يناير - مارس المس مسلة 2015. 
بحوث العلاقات العامة والاعلان فى مصر :الواقع واتجاهات المستقبل

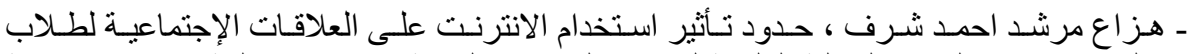

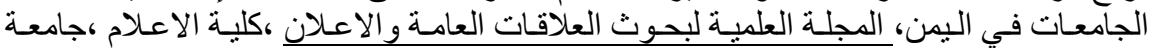

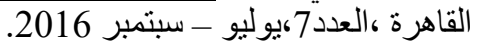

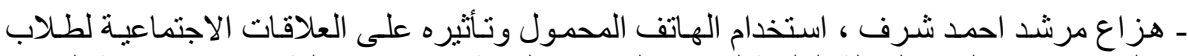

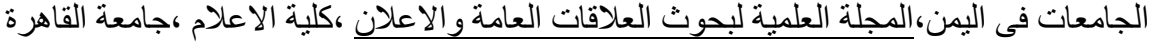

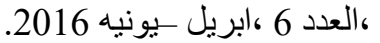

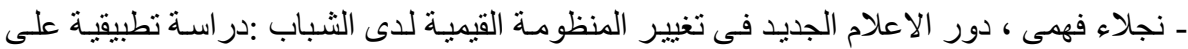

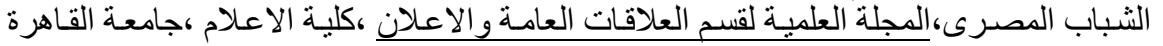

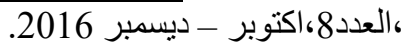

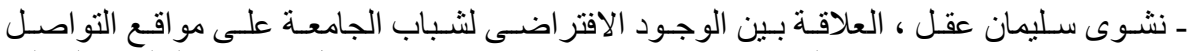

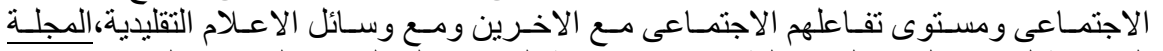

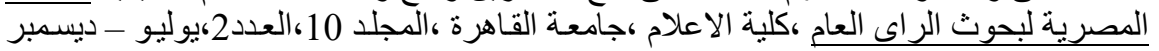

ـ امال كمال ، استخدام طلاب الجامعات المصرية لمو اقع الثبكات الاجتماعية وعلاقتته بر اس المـال

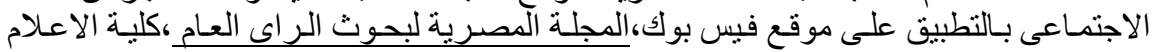

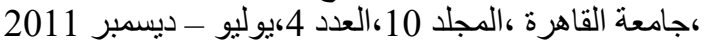

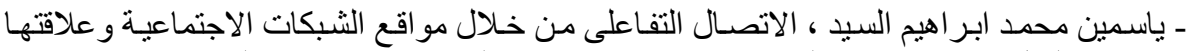

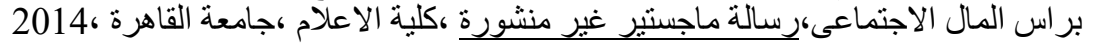

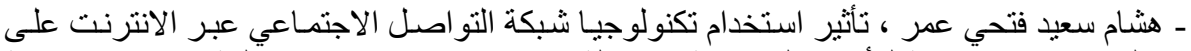

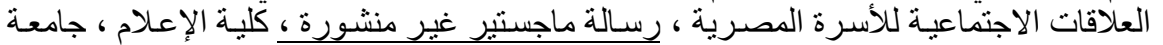

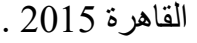

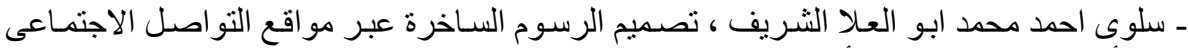

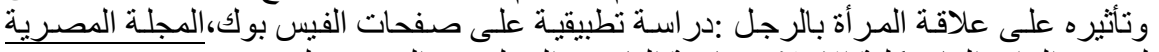

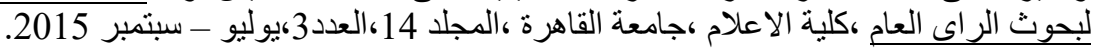

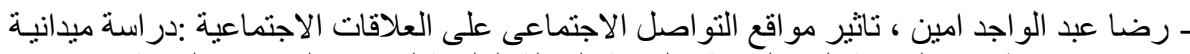

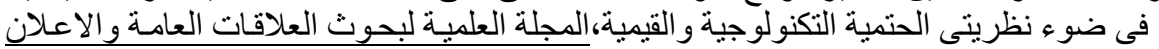

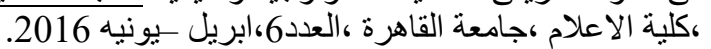

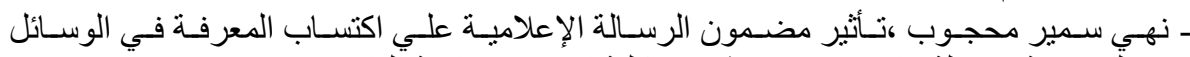

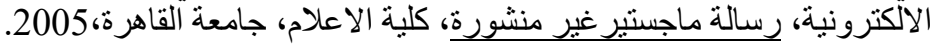

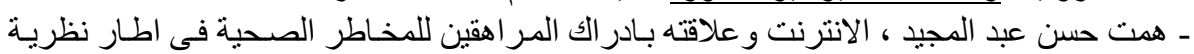

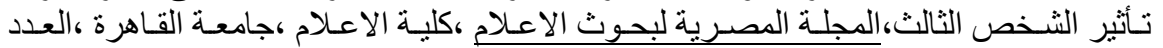

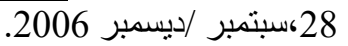
-وليد فتح الله، دور اساليب الاتصال الاليكترونى عبر الانترنت في دعم الانثطة الاكاديمية :دراسة

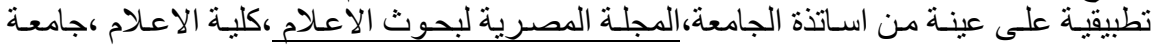

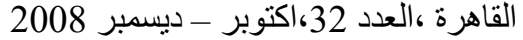

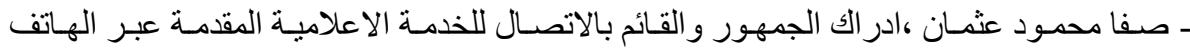

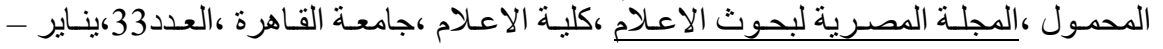
يونيه2009. 


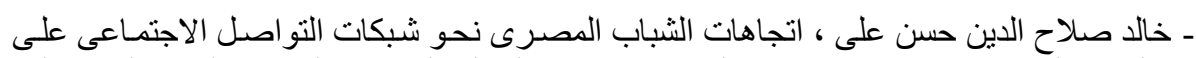

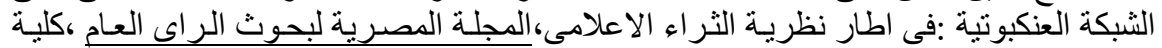

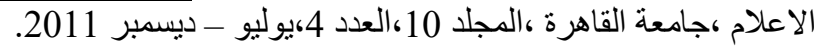

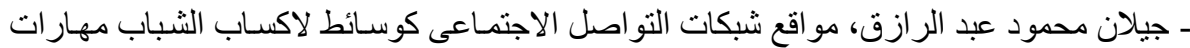

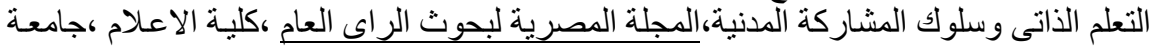

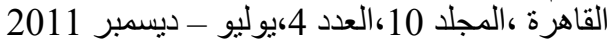

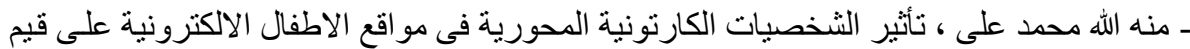

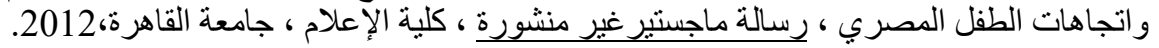

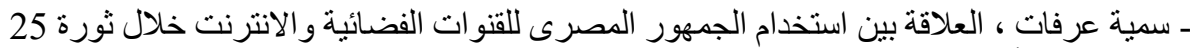

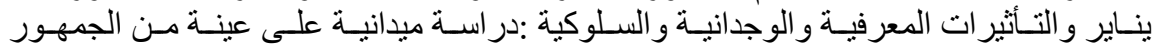

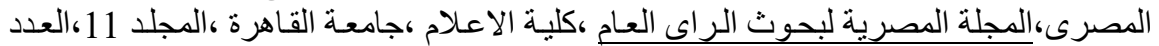

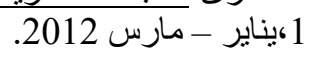

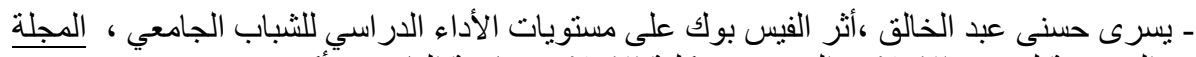

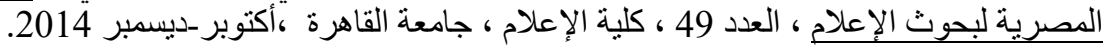

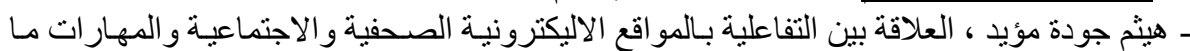

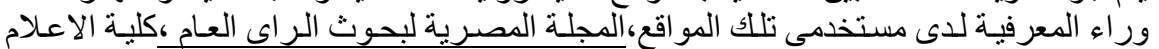

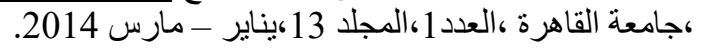

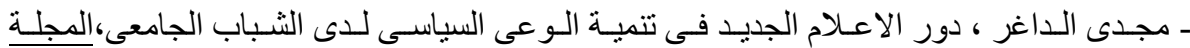

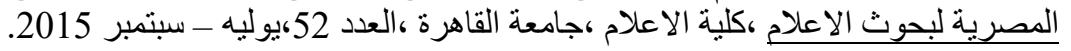

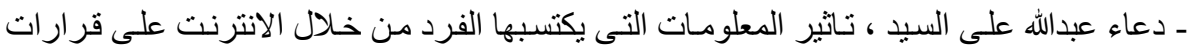

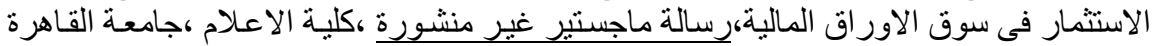
.2016،

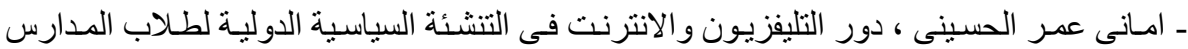

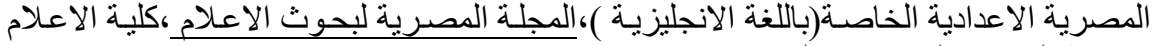

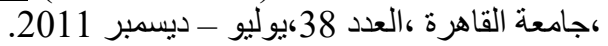

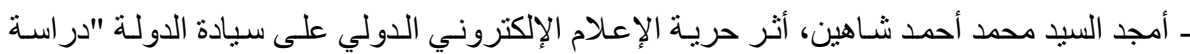

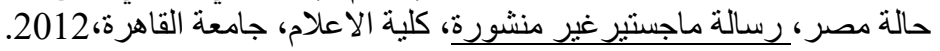

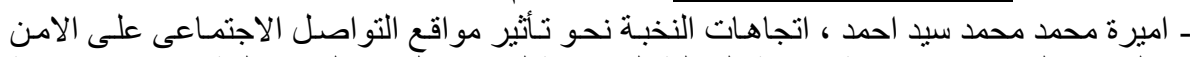

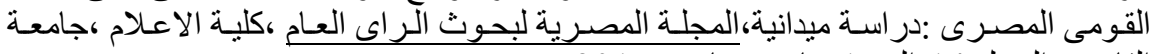

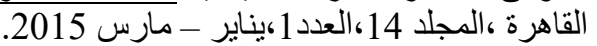

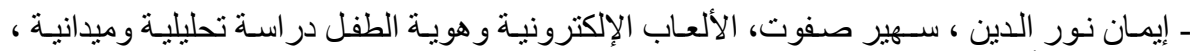

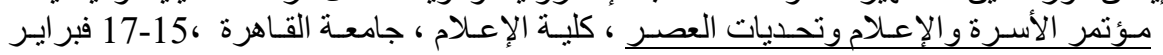
2009

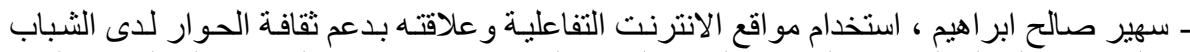

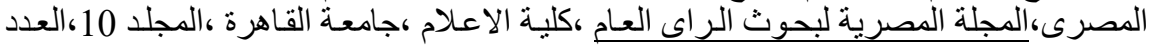

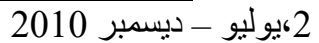

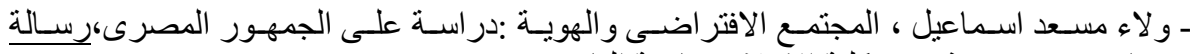
ماجستير غير منشورة ،كلية الاعلام ،جامعة القاهرة ، 2011. 


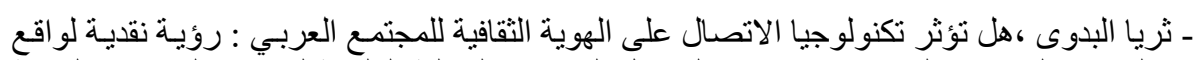

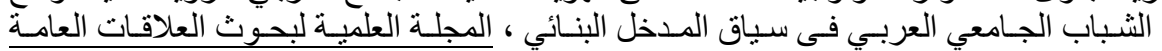

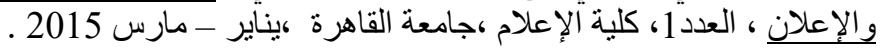

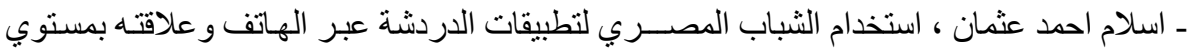
ثقافة الحوار لايهم ،المجلة العلمية لقسم العلاقات العامة والاعلاتلان ،كلية الاعلام ،جامعة القاهرة

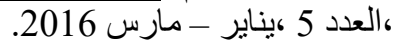

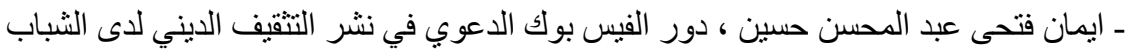

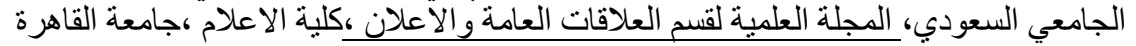

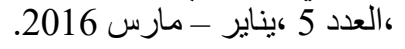

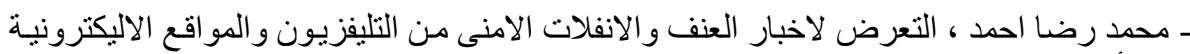

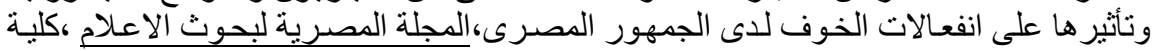

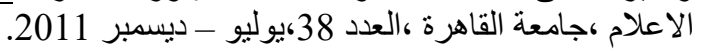

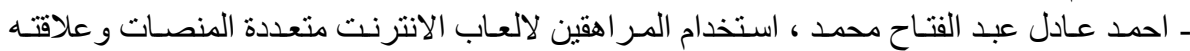

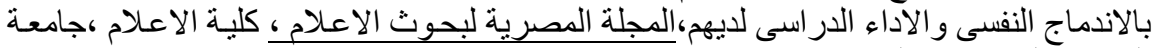

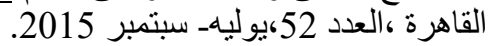

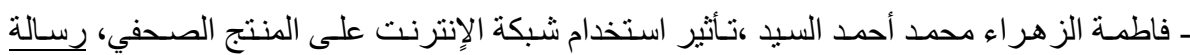

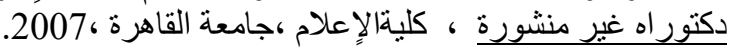

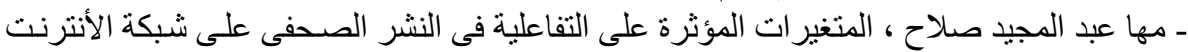

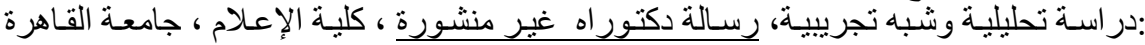
.2007،

ـ سيد بخيت، ادو ار مستخدمى المو اقع الاليكترونية فى صناعة المضامين الاعلامية، المجلة المصرية

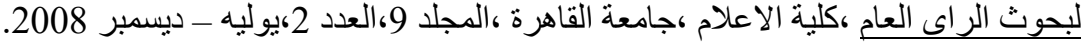

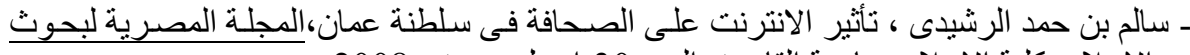

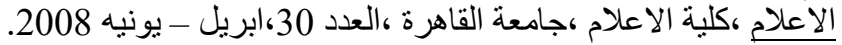

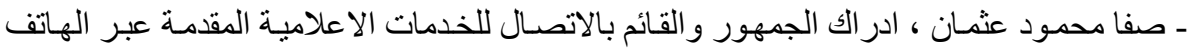
المحمول،المجلة المصرية لبحوث الاعلام ،كلية الاعلام ،جامعة القاهرة ،العدد 33،يناير - يونيه الإنيه

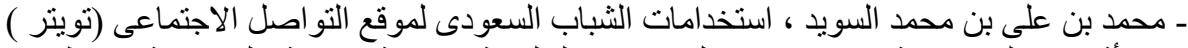

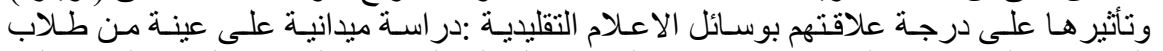

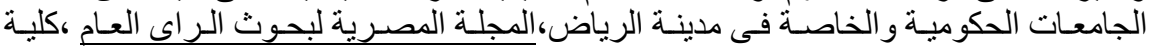

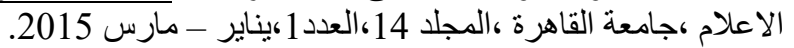

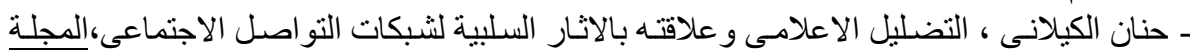

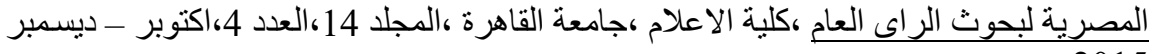
2015

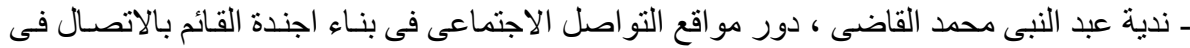

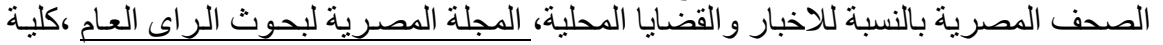

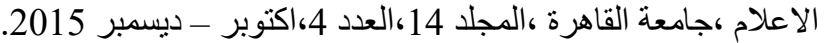

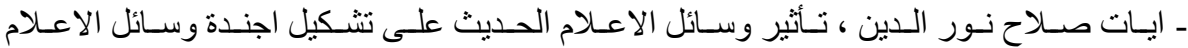
التقليدية،رسالة ماجستير غير منشورة ،كلية الاعلام ،جامعة القاهرة ،2016. 


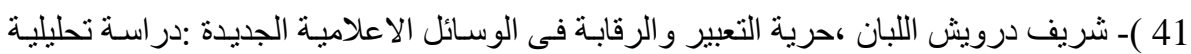

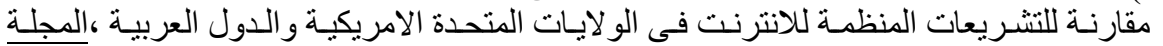

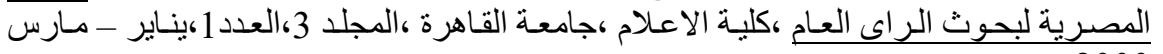

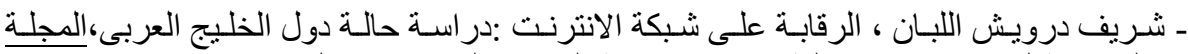

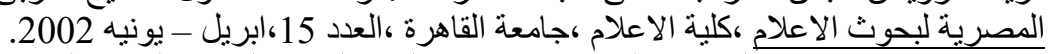

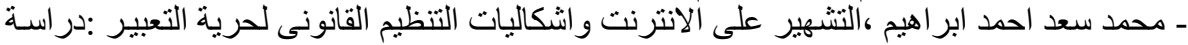

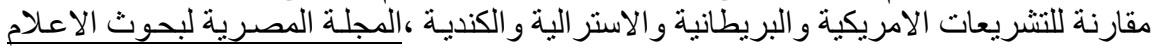

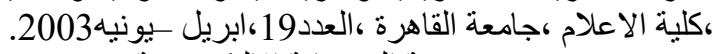

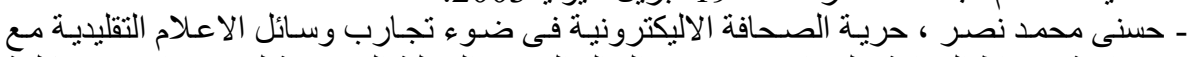

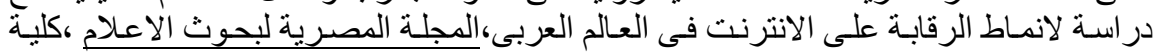

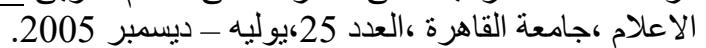

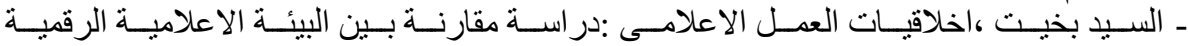

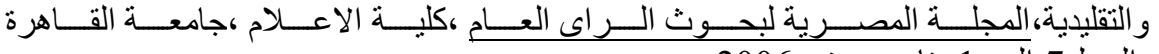

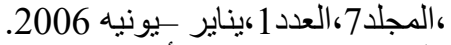

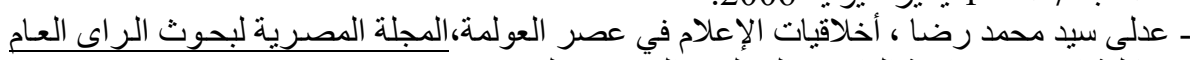

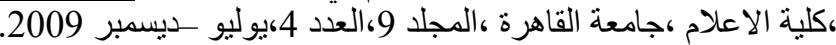

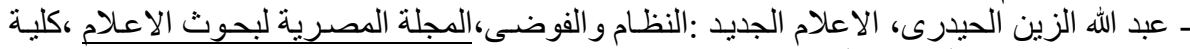

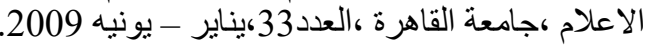

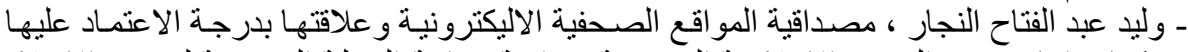

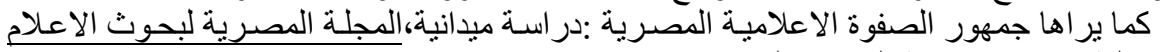

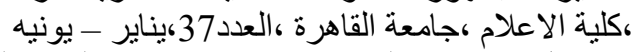

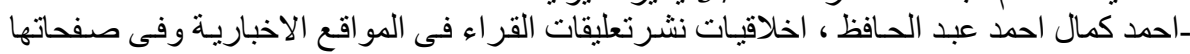

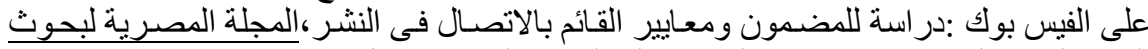

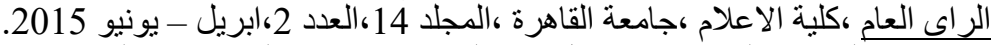

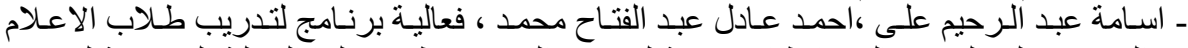

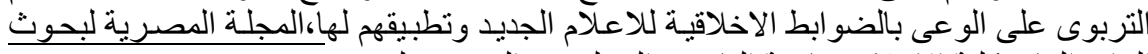

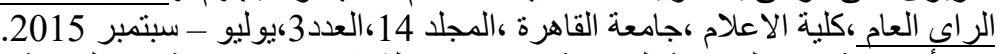

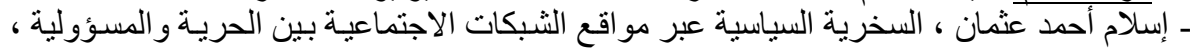

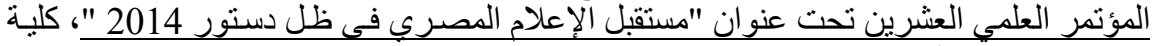

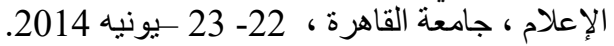

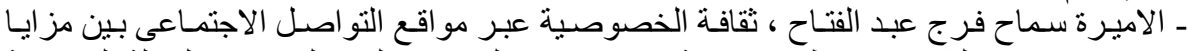

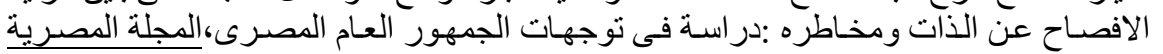

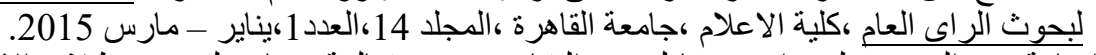

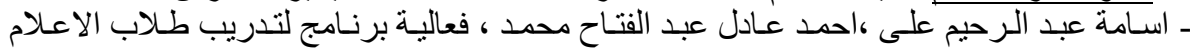

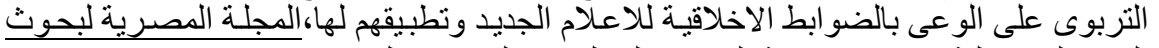

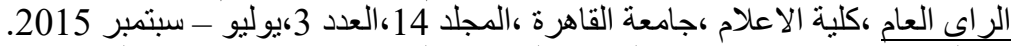

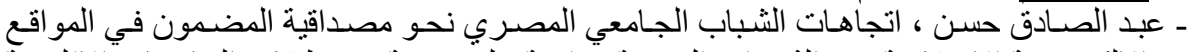

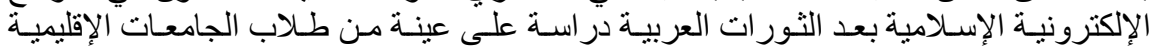

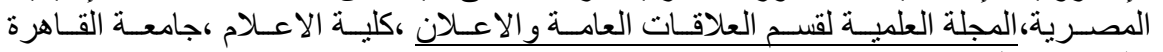
،العدد2،ابريل - يونيو 2015. 
ـ عبير ابر اهيم محمد رجب عزى ، تأثير ات استخدام المعلنين لملفات تعريف الارتباط (الكوكيز)

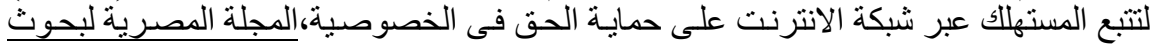

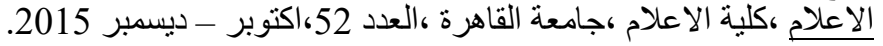

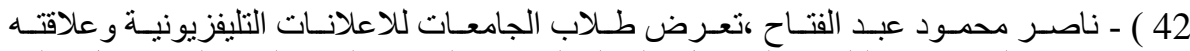

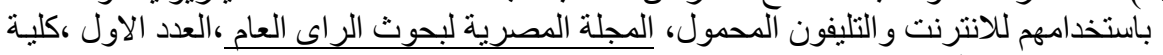
الاعلام جامعة القاهرة 2005.

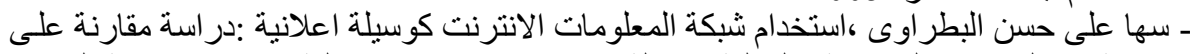

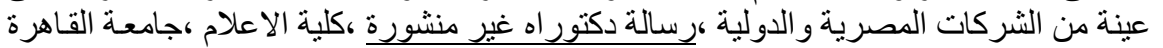
.2006،

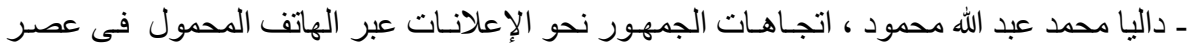

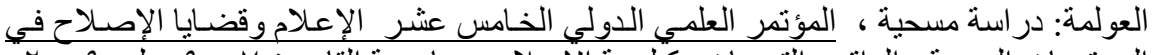

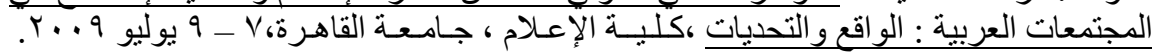

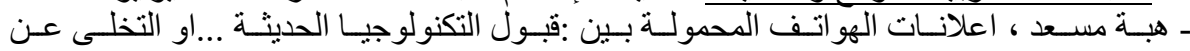

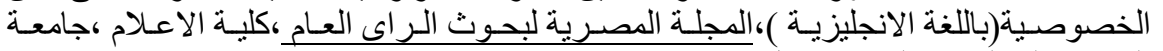

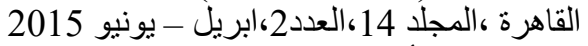

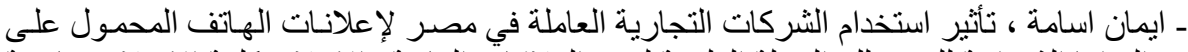

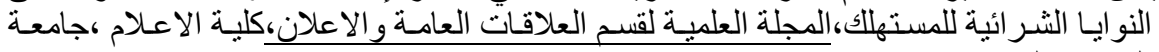

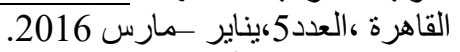

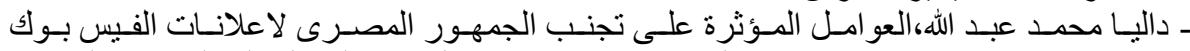

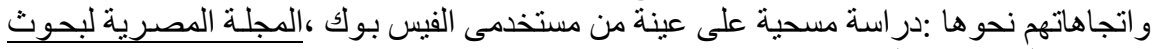

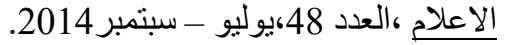

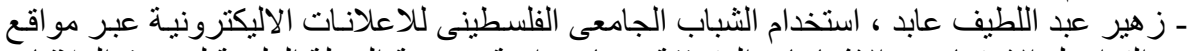

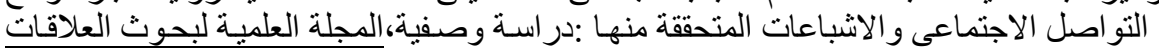

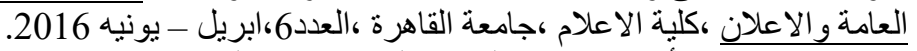

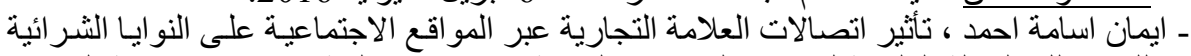

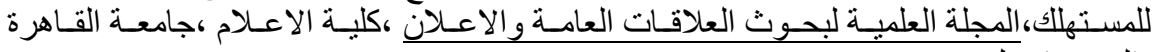

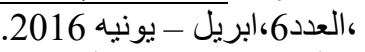
ـعبد الصادق حسن عبد الصادق، اثنر التكنولوجيا الحديثة فى تطوير اخر اج العناصر الجر افيكية فيى

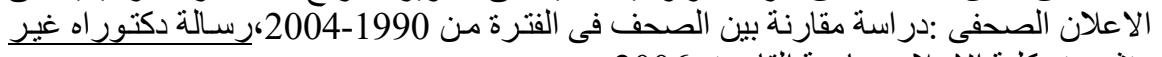

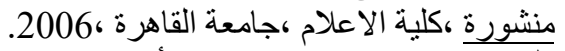

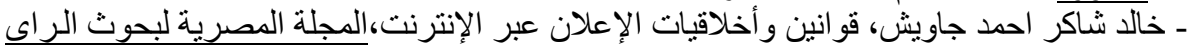

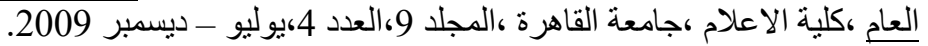

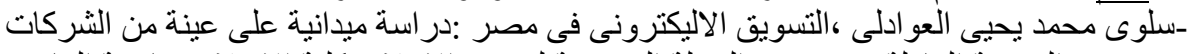

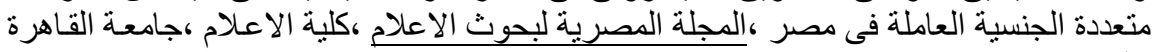

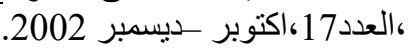

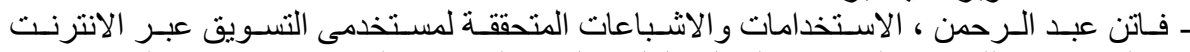

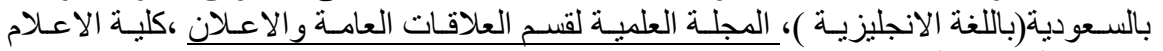

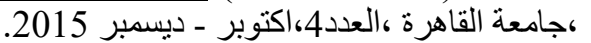

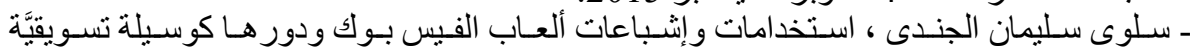
حديثة، المجلة العلمية لقسم العلاقات العامة والاعلان ،بات ،كلية الاعلام ،جامعة القاهرة ،العدد5،يناير - مارس 2016. 


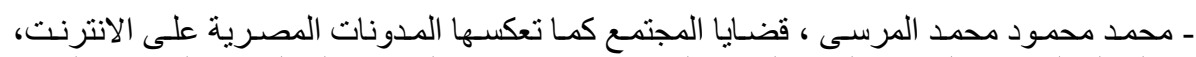

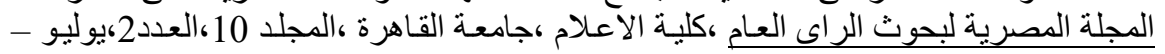
ديسمبر 2010. - حنان احمد سليم ،الحملات الإعلامية عبر الإعلام الجديد رؤية مستقبلية لنموذج تفاعلي ، المجلية

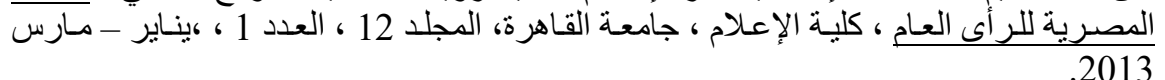

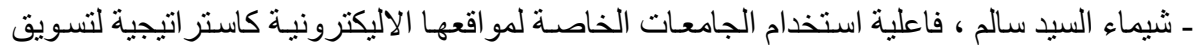

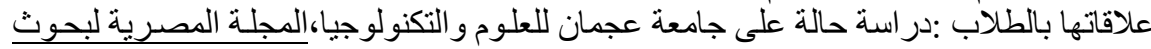

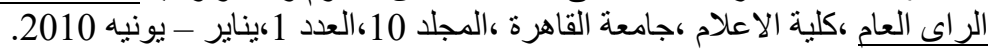

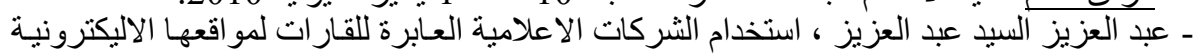

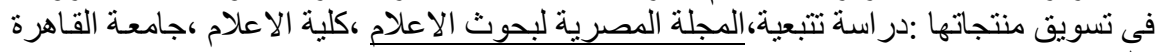

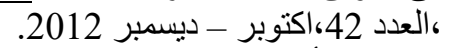

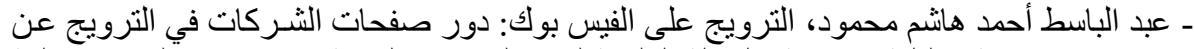

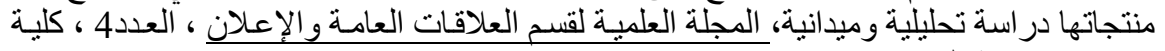

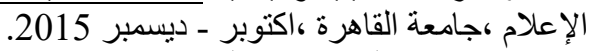

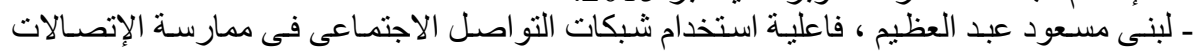

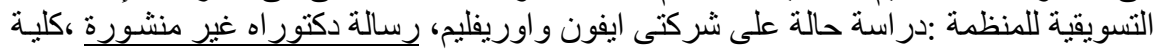
الاعلام ،جامعة القاهرة ، 2016.

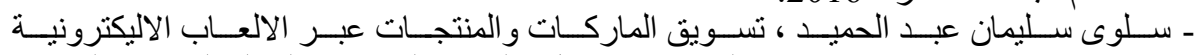

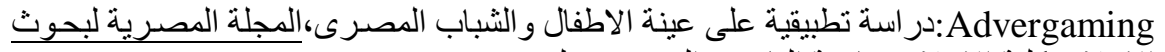

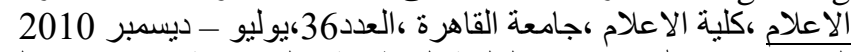

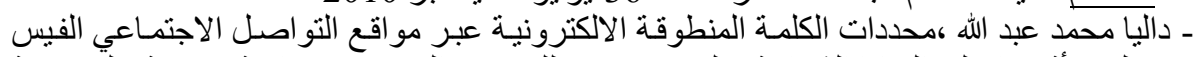

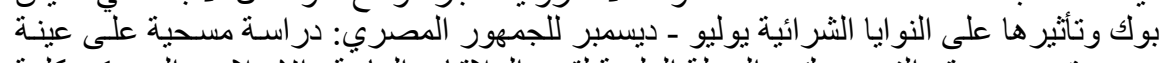

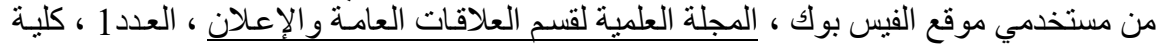

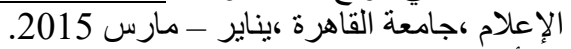

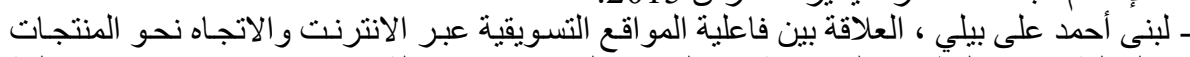

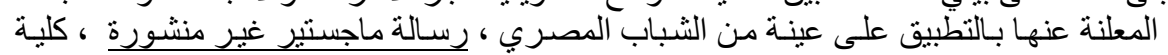
الإعلام، جامعة القاهرة ،2016.

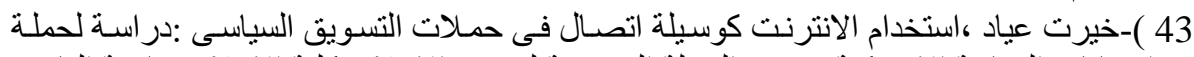

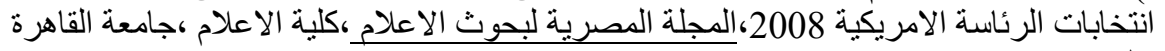

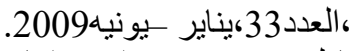

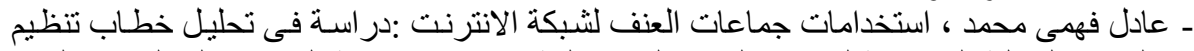

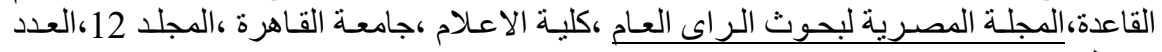
3،يوليو - ديسمبر 2014.

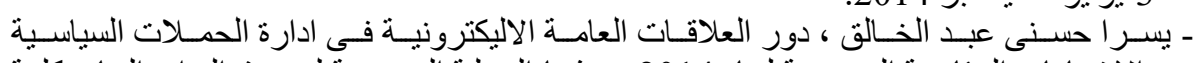

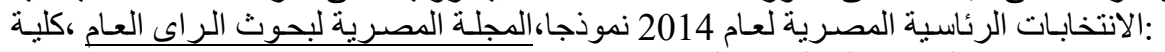

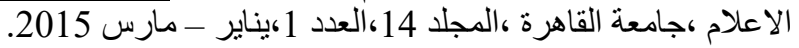

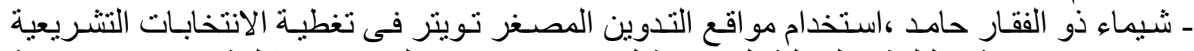

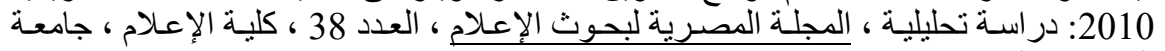

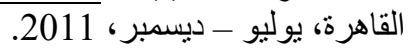


بحوث العلاقات العامة والاعلان فى مصر :الواقع واتجاهات المستقبل

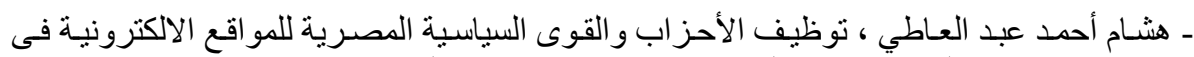

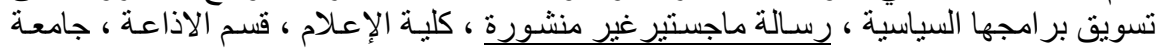

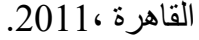

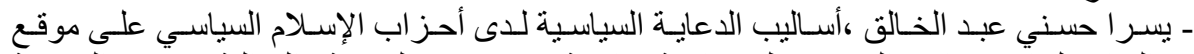

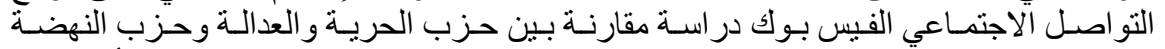

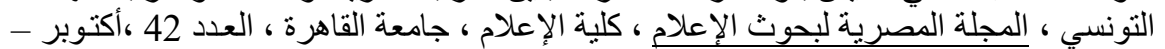

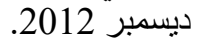

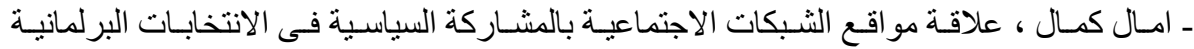

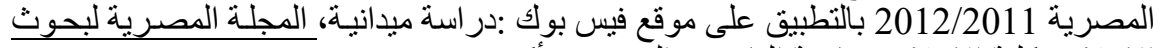

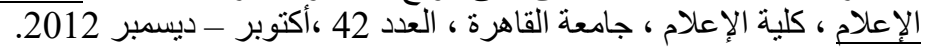

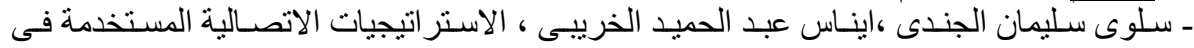

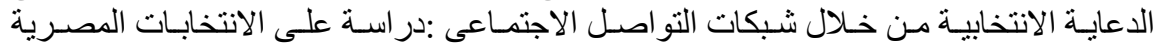

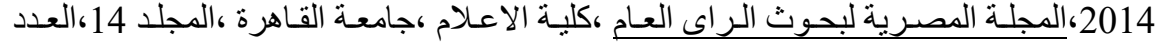
1 ايناير -مارس 2015 - 2015.

ـ مر ام حسين محمود حافظ ، توظيف مو اقع التو اصل الاجتم التماعى (الفيسبوك) في الدعاية الانتخابية

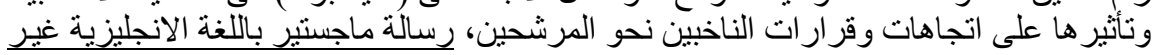
منشورة ،كلية الاعلام ،جامعة القاهرة ،

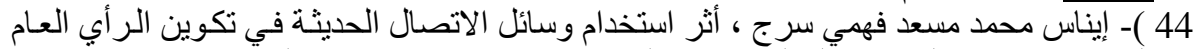

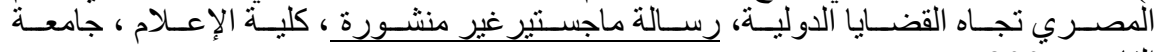

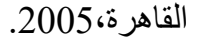

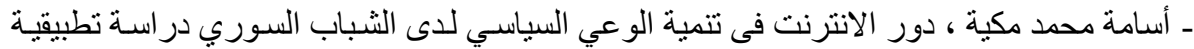
على مو اقع التو اصل الاجتماعي ، رسالة ماجنتير غير منشورة ، كلية الإعلام ، جامعة القاهرة 2013،

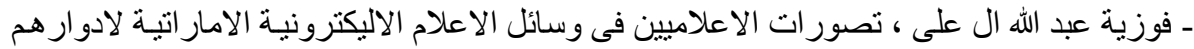

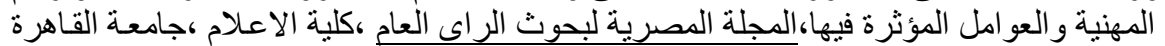

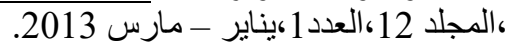

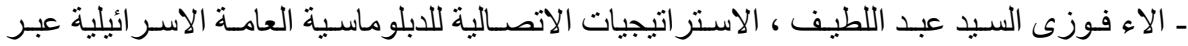

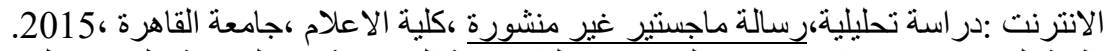

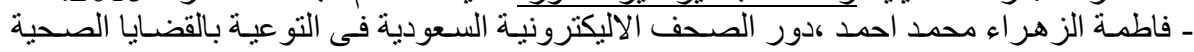

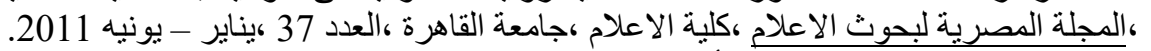

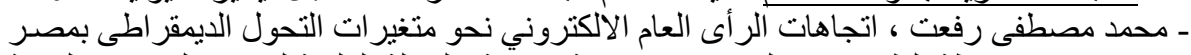

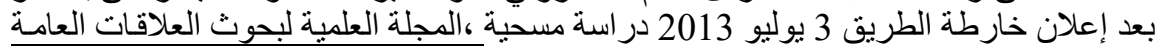

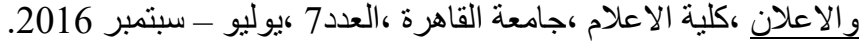

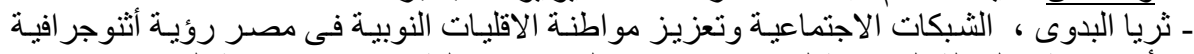

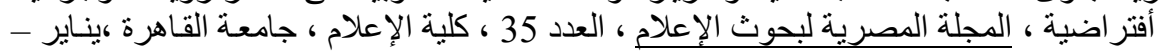
يونيه 2010.

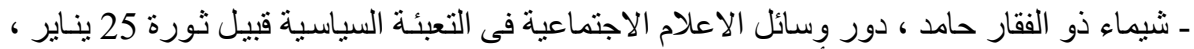

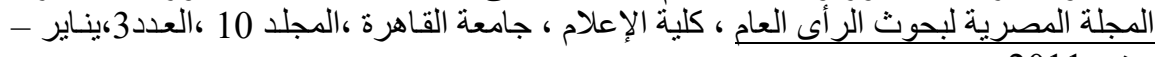
يونيو 2011

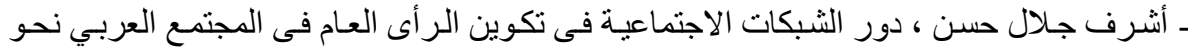

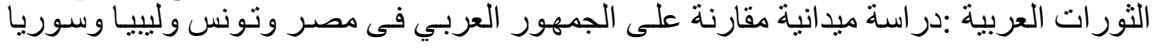


بحوث العلاقات العامة والاعلان فى مصر :الواقع واتجاهات المستقبل

و اليمن، المؤتمر العلمي الدولي الثامن عشر تحت عنوان " الإعلام وبناء الدولة الحديثة "، كلية

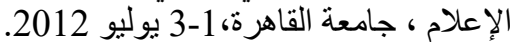

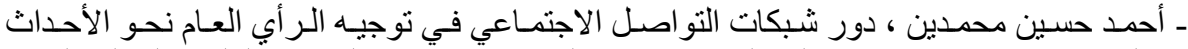

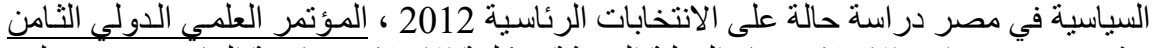

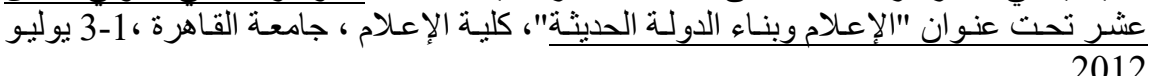

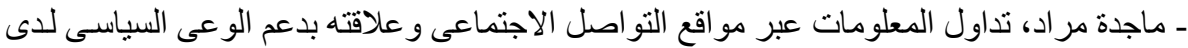

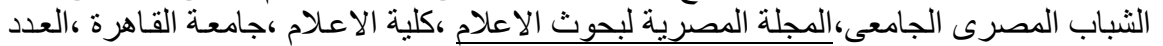

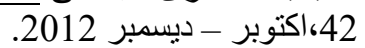

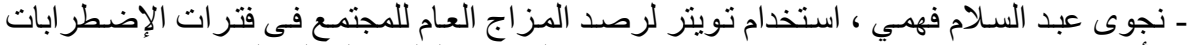

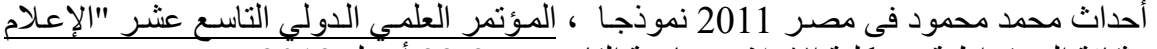

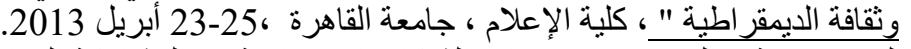

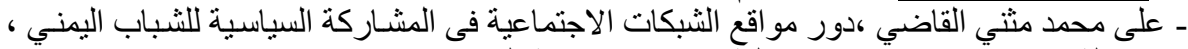

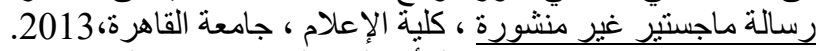

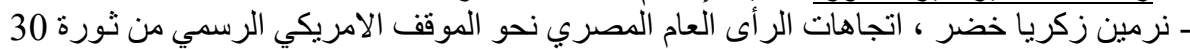

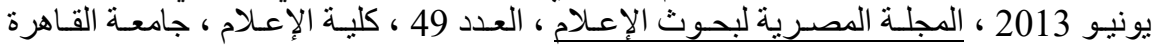

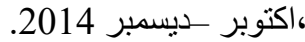

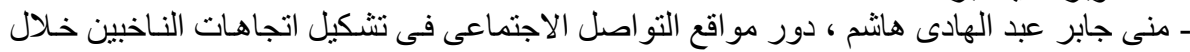

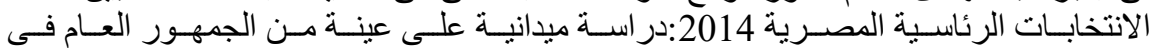

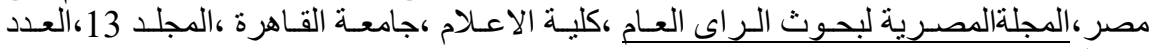

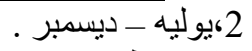

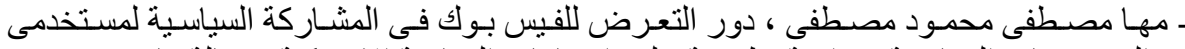

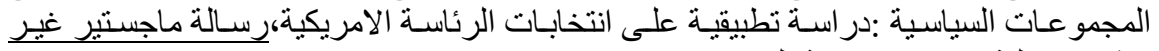

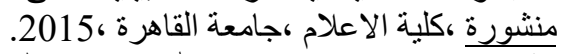

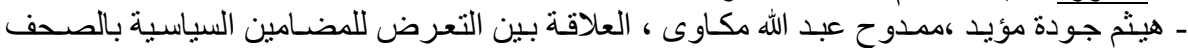

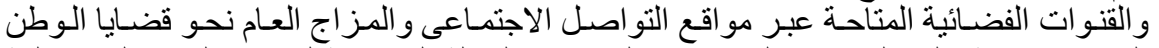

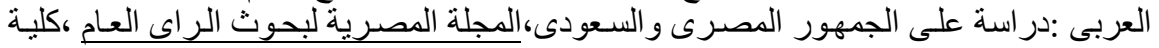

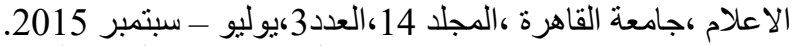

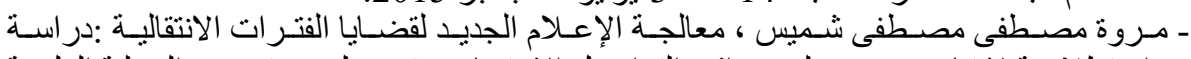

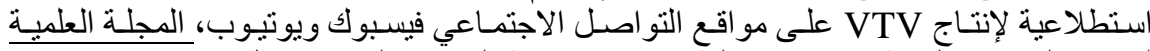

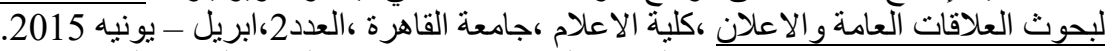

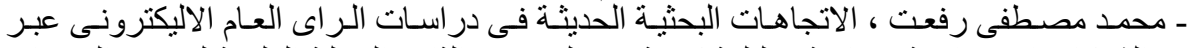

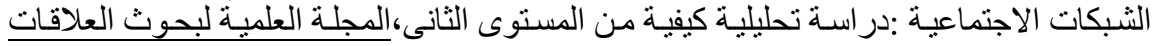

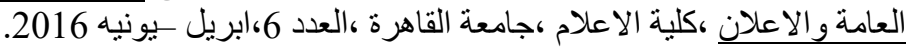

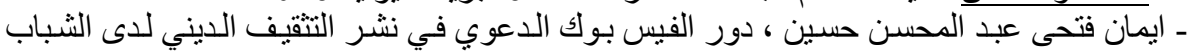

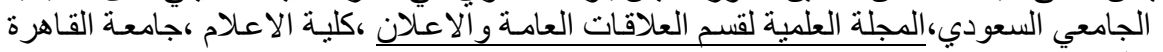

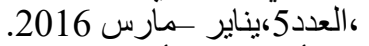

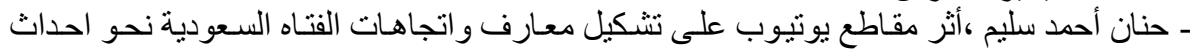
الثورة المصرية ، المجلة المصرية لبحوث الإعلام، العدد 38 ، كلية الإعلام ، جامعة القاهرة ،

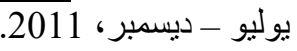




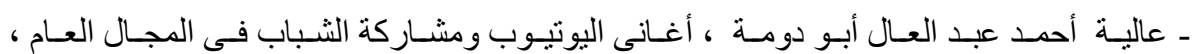

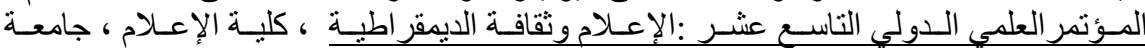

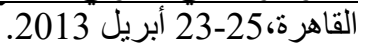

ـ عبد الجو اد سعيد محمد ربيع ، المدونات كأداة اتصال تفاعلي في المشاركة السياسية :در اسة تحليلية

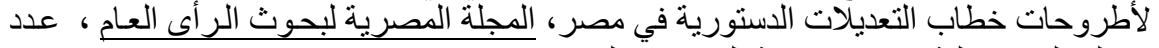

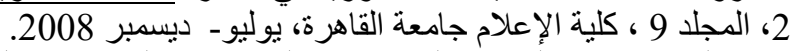

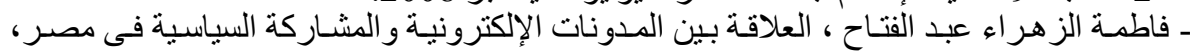

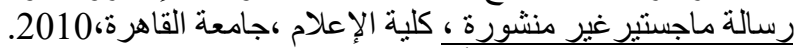

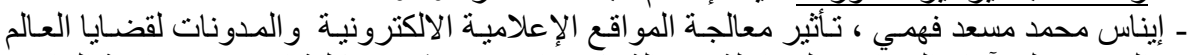
العربي على آراء الجمأهبر المتفاعلة، رسالة دكتور الهي غير منثورة، كلية الاعلام ، جامعة القاهرة .2014،

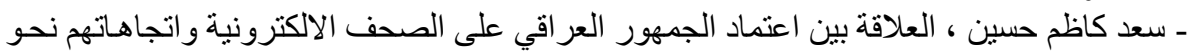

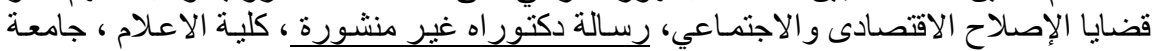

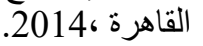

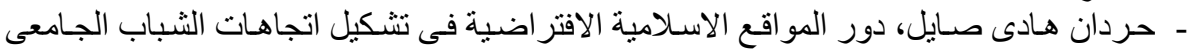
العر اقى نحو القضايا الدينية المعاصرة، دسالة دكتور اهلية غير منشورة ،كلية الاعلام ،جامعة القاهرة .2015،

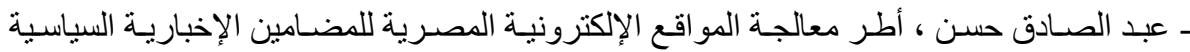

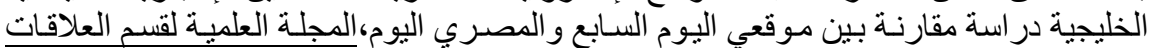

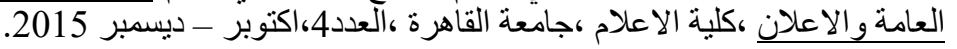

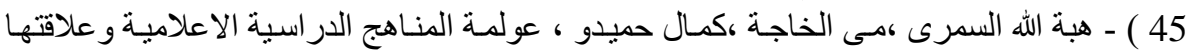

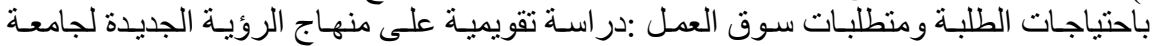

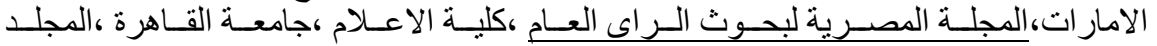

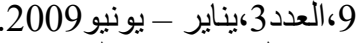

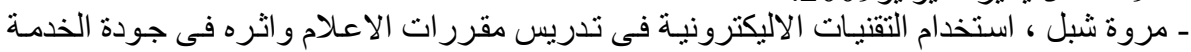

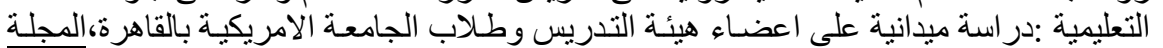

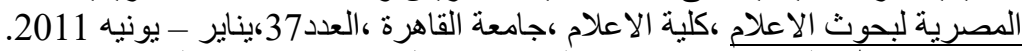

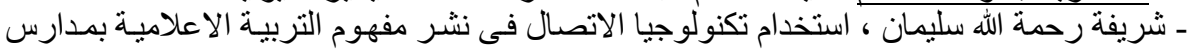

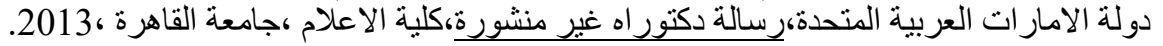

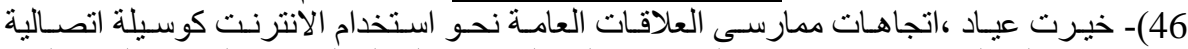

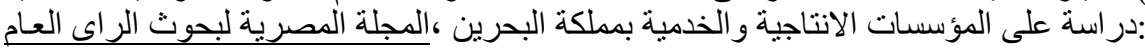

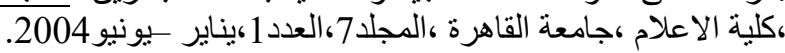

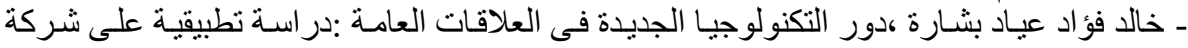

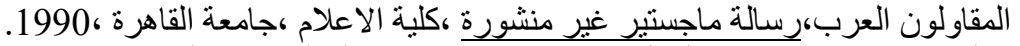

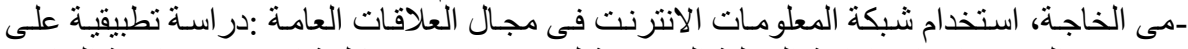

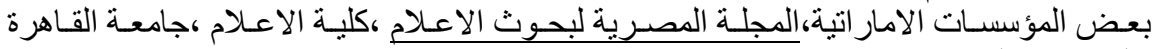

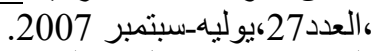

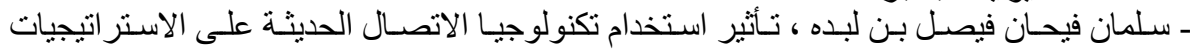
الاتصالية للعلاقات العامة فى المؤسسات السعودية ، رسالة دكتور اهلئ غير منشورة ، كلية الإعلام ،

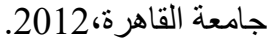




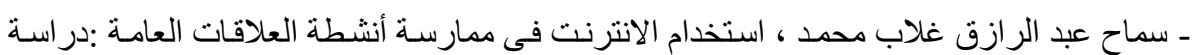

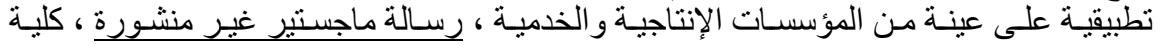

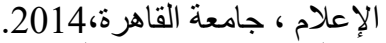

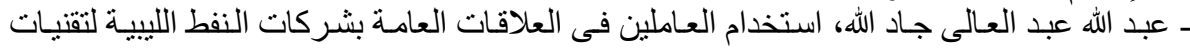

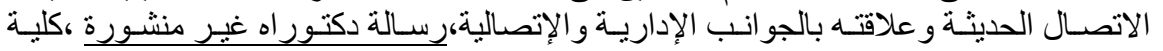
الاعلام ،جامعة القاهرة ، 2015.

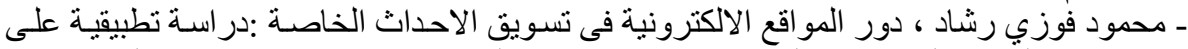

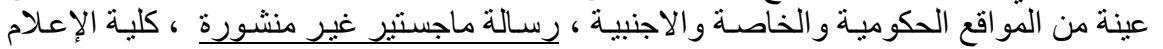

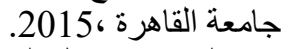
ـ حاتم على حيذر مقبل الصالحى ، استخدام تكنولوجيا الاتصال التفاعلى فى ممارسة انثطة العلاقات

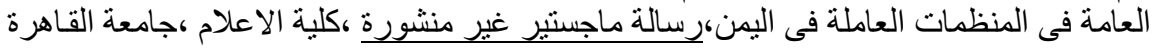
.2015،

ــ محمد شعبان محمد عبد الفتاح العيسوى ، استخدام العلاقات العامـة الاليكترونيـة لتحقيق الرضيا

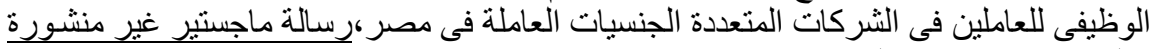

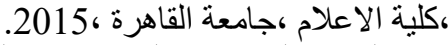

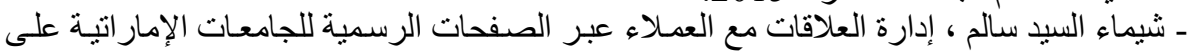

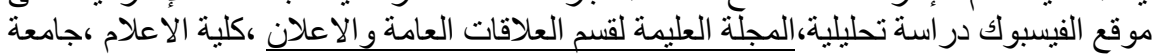

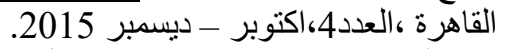

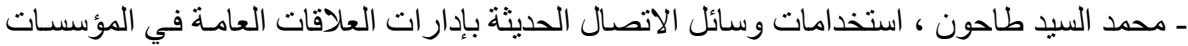

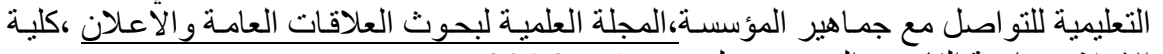

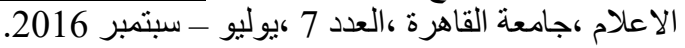

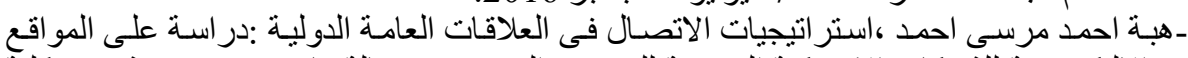

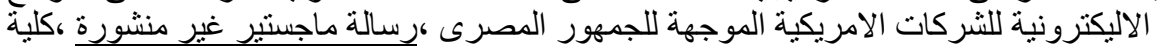

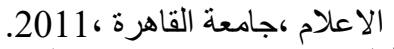

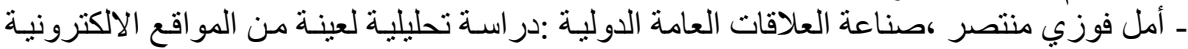

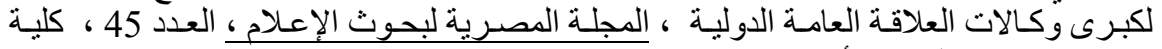
الإعلام ، جامعة القاهرة، أكتوبر - ديسمبر الإلية 2013.

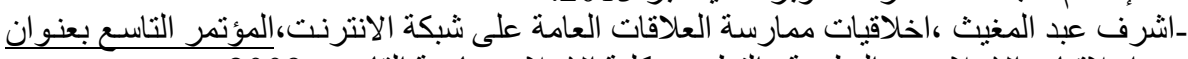

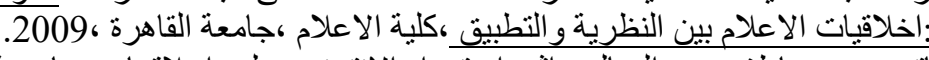

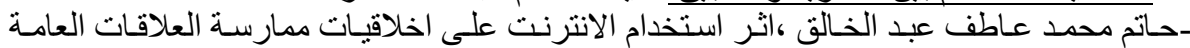
:در اسة تطبيقية ،رسالة ماجستير غير منشورة ،كلية الاعلام ،جامعة القاهرة ،

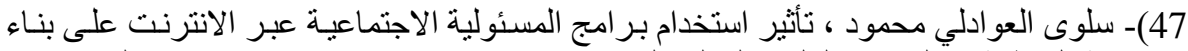

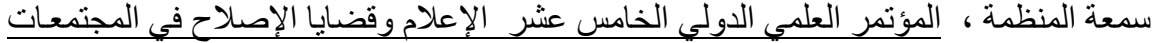

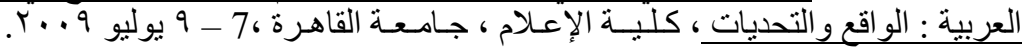

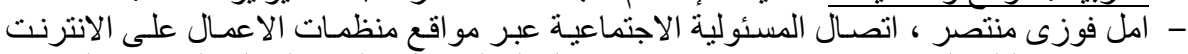

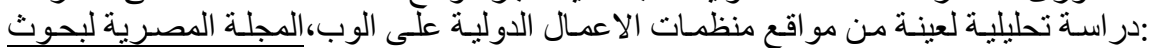

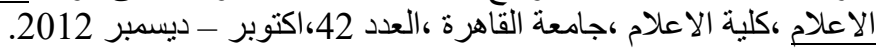

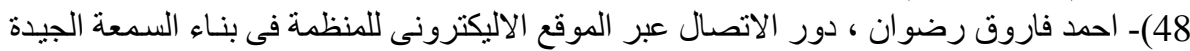

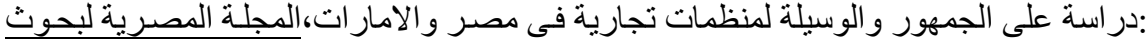

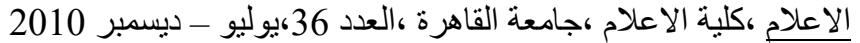

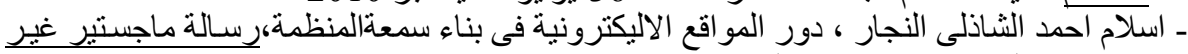
منشورة ،كلية الاعلام ،جامعة القاهرة ،2015. 
49) - امانى فهمى ، الاعتماد على الثبكات الاجتماعية خلال أزمة الاتصـالات في ثورة 25 يناير

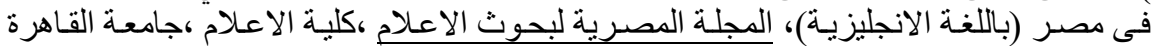

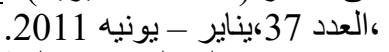

ـ ابو بكر حبيب الصالحى ، معالجة مواقع الصحف الاليكترونية المصرية للازمات السيه السياسية العربيـة

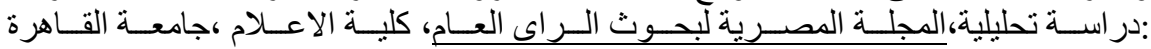

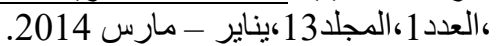

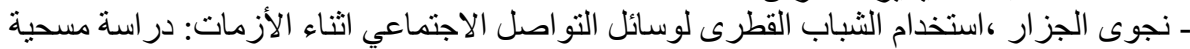

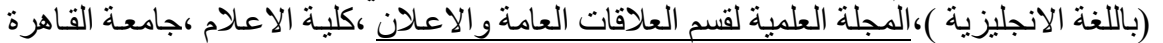

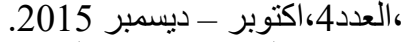

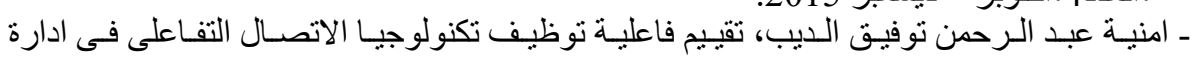

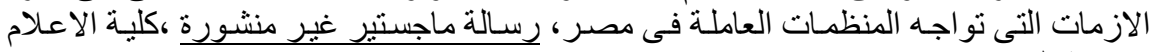

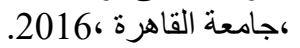

ـ ايناس عبد الحميد ، استر اتيجيات الاستجابة للازمات التى تستخدمها الاحز اب السياسبة فى وسائل

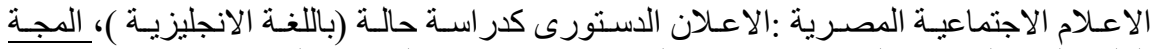

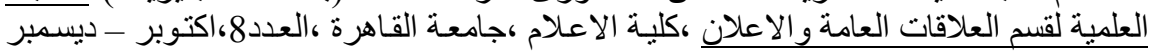
.2016

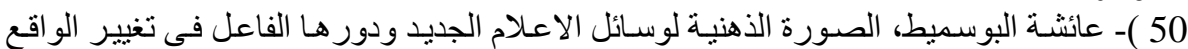

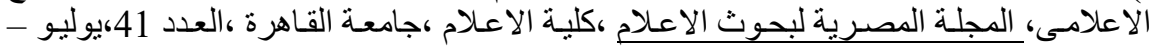

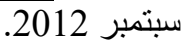

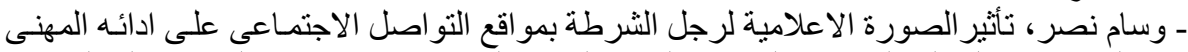

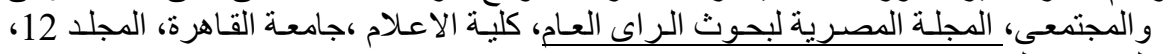

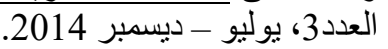

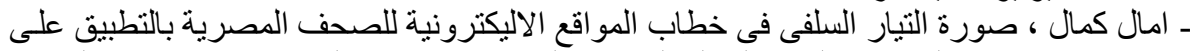

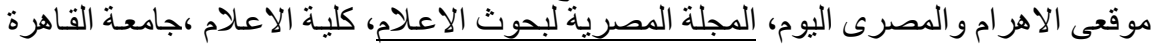

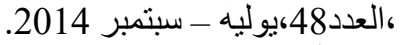

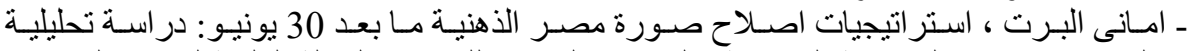

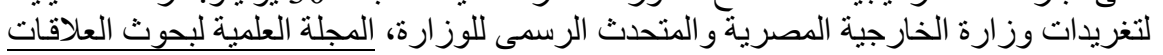

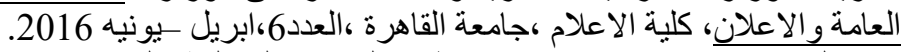

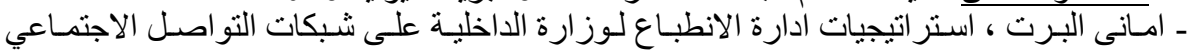

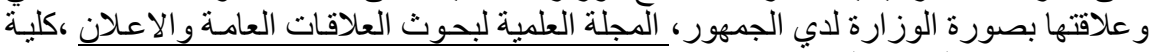

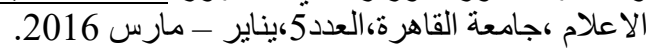

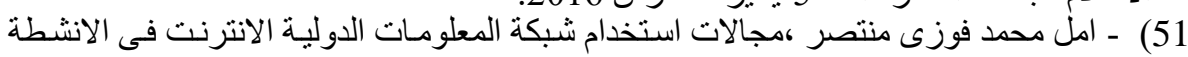

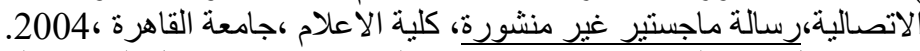

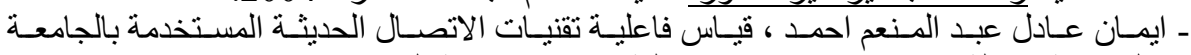
المفتوحة،رسالة ماجستير غير منشورة، كلبة الاعلام العام ،جامعة القاهرة ،2012.

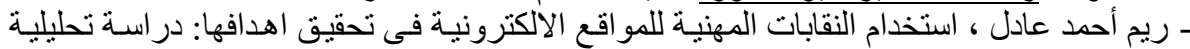

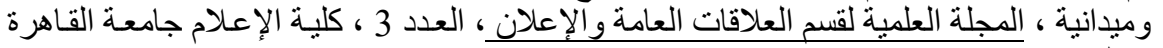

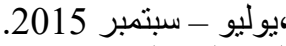

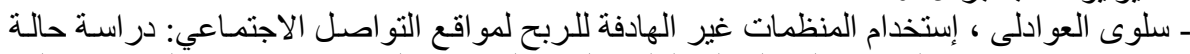

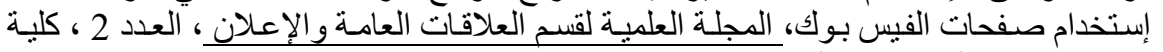
الإعلام جامعة القاهرة ،ابريل - يونيه 2015. 
بحوث العلاقات العامة والاعلان فى مصر :الواقع واتجاهات المستقبل

ـ معصم بلال جمعة عبد الله المعصم ، دور وسائل الاتصـال الحديثة فى تفعيل العلاقة ديع الجمهور

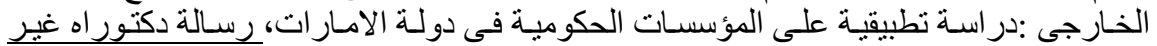
منشورة ،كلية الاعلام ،جامعة القاهرة ،2016. 